\title{
Interseções entre arte e arquitetura: Práticas espaciais críticas
}

\author{
Ana Carolina Tonetti \\ Tese apresentada ao Programa de Pós-Graduação da Faculdade de \\ Arquitetura e Urbanismo da Universidade de São Paulo para a obtenção do \\ título de Doutora em Arquitetura e Urbanismo \\ Área de concentração: \\ Projeto, Espaço e Cultura \\ Orientador: \\ Prof. Dr. Agnaldo Aricê Caldas Farias
}

Exemplar revisado e alterado em relação à versão original, sob responsabilidade da autora e anuência do orientador. A versão original, em formato digital, ficará arquivada na Biblioteca da Faculdade.

São Paulo, 23 de novembro de 2020

São Paulo

2020 
Autorizo a reprodução e divulgação total ou parcial deste trabalho, por qualquer meio digital ou eletrônico, para fins de estudo desde que citada a fonte.

email: caroltonetti@alumni.usp.br

Catalogação na Publicação

Serviço Técnico de Biblioteca

Faculdade de Arquitetura e Urbanismo da Universidade de São Paulo

Tonetti, Ana Carolina

Interseções entre arte e arquiteutra: Práticas espaciais

críticas. / Ana Carolina Tonetti; orientador Agnaldo Aricê

Caldas Farias. - São Paulo, 2020.

$240 \mathrm{p}$.

Tese (Doutorado) - Faculdade de Arquitetura e Urbanismo da Universidade de São Paulo. Área de concentração: Projeto, Espaço e Cultura.

1. Arquitetura. 2. Arte Contemporânea. 3. Espaço. 4. Campo Ampliado. I. Farias, Agnaldo Aricê Caldas, orient. II. Título.

Elaborada eletrônicamente através do formulário disponivel em: http://www.fau.usp.br/fichacatalografica/ 


\section{Folha de Aprovação}

TONETTI, Ana Carolina

Interseções entre arte e arquitetura:

Práticas espaciais críticas

Tese apresentada ao Programa de Pós-Graduação da Faculdade de Arquitetura e Urbanismo da Universidade de São Paulo, na área de concentração Projeto, Espaço e Cultura, para a obtenção do título de Doutora em Arquitetura e Urbanismo

Aprovada em 29 de abril de 2020

Banca examinadora:

Profa. Dra. Fernanda Fernandes da Silva

Instituição: FAU-USP

Prof. Dr. Fabio Lopes de Souza Santos

Instituição: IAU-USP

Prof. Dr. Otavio Leonídio Ribeiro

Instituição: PUC-RJ

Profa. Dra. Renata Moreira Marquez

Instituição: UFMG 



\section{Agradecimentos}

Antes de mais nada, agradeço ao meu orientador, Agnaldo Farias, por sua orientação segura e confiança em meu trabalho.

O período de elaboração dessa tese foi atravessado por experiências de trabalho intensas e transformadoras. A amizade e partilha de pesquisas e questões com $\mathrm{O}$ grupo inteiro, nos últimos cinco anos, foram um aspecto fundamental de apoio pessoal. Obrigada Claudio, Ligia e Vitor, vocês estão presentes de inúmeras maneiras em muitas dessas linhas.

Gostaria de agradecer a vários colegas da Escola da Cidade pela compreensão quando precisei me recolher para o período final da escrita, particularmente à Maira Rios e à equipe da biblioteca Vilanova Artigas, com seu simpático apoio. Também é importante relembrar o período em que dividi a sala de aula com Gilberto Mariotti, com quem tive o prazer de montar um curso no qual elaborei muitas das questões que aqui desenvolvi.

Agradeço ainda pela disponibilidade e generosidade de artistas, arquitetos e curadores, pessoas que admiro e que me receberam para boas conversas, das quais extraí elementos para as análises de casos que fortaleceram o trabalho. São elas: Ana Maria Maia, Graziela Kunsch, Luiza Proença, Mel Dodd - cuja contribuição e envolvimento com o projeto Contracondutas tem rebatimentos nessa tese -, e Liza Fior, que gentilmente passou uma tarde comigo conversando sobre o Muf.

Não posso deixar de agradecer ao Eduardo Gurian, por partilhar o interesse em indeterminações e modos de representação, cedendo o belo desenho da Marquise; ao grupo de estudos de arte e arquitetura da FAU-USP, cujos encontros, ainda que inconstantes, renderam boas leituras e debates mediados por Guilherme Wisnik; à Ana Luiza Nobre, pelo incentivo em um momento de aperto; à Marina Grinover, pelo envio de um artigo importante; ao Diogo de Moraes, por dividir um texto sobre $A$ Marquise o Mam e nós no meio, com o qual o meu dialoga; ao David Sperling, pela leitura cuidadosa com comentários encorajadores durante a qualificação; à banca examinadora e sua leitura que assinalou ajustes precisos; à Ana Godoy, por me mostrar que era possível "mixar" ideias e assumir uma escrita fragmentária, dando sentido e movimento ao meu texto.

Por fim, agradeço ao André, por todo o cuidado e todas as (incontáveis) leituras dutante um verão ameno. 

A divisão da arte nas categorias pintura, arquitetura e escultura parece ser uma das coisas mais malsucedidas que já ocorreu. Agora, todas essas categorias estâo se fragmentando em mais categorias, como uma avalanche de categorias.

Robert Smithson 


\section{Abstract}

Intersections between Art and Architecture:

Critical Spatial Practices

The ruptures undertaken by the arts, from the 1960s on, and the revision of modern postulates by architecture that occurred in the same period, represent an important moment of inflection and narrowing of the limits between these two fields in the context of an expanded cultural debate.

Since the notion of space is crucial to understanding the relationships between three-dimensional production and architecture, it will be examined in the light of the concept of "spatial practice" that was taken up by the international architecture criticism in the 1990s, from the formulation by Henri Lefebvre in The Production of Space (1974).

This work starts from the hypothesis that the closest involvement with specific contexts and social reality problematize previous categories, and provoke repercussions in the process of documentation and representation, expanding architectural practice. As a result, the architectural project starts to incorporate discursive layers that promote a reflection on its means of production, representation an publicization in a displacement analogous to the inversion of signs proposed by the dialectic between site and non-site in the work of artist Robert Smithson.

Keywords: architecture, contemporary art, space, spatial practice, site-specific, professional practice, architecture project, participation, expanded field. 


\section{Resumo}

As rupturas empreendidas pelas artes, a partir dos anos 1960, e a revisão dos postulados modernos pela arquitetura ocorrida no mesmo período, representam um importante momento de inflexão e de estreitamento dos limites entre esses campos no contexto de um debate cultural ampliado.

Uma vez que o entendimento de espaço é central para a compreensão das relações entre a produção tridimensional e a arquitetura, ele será examinado à luz do conceito de "prática espacial" que foi retomado pela crítica de arquitetura internacional nos anos 1990, a partir da formulação de Henri Lefebvre em A Produção do Espaço (1974).

Parte-se da hipótese de que o envolvimento mais próximo com contextos específicos e com a realidade social problematizam categorias anteriores, e provocam rebatimentos em processos de documentação e representação alargando a prática arquitetônica. Como resultado, o projeto arquitetônico passa a incorporar camadas discursivas que promovem uma reflexão sobre seus meios de produção, representação e comunicação, em um deslocamento análogo à inversão de sinais proposta pela dialética entre sítio e não-sítio na obra do artista Robert Smithson.

Palavras-chave: arquitetura, arte contemporânea, espaço, prática espacial, site-specific, prática profissional, projeto arquitetônico, participação, campo ampliado. 



\section{Sumário}

13 Introdução

26 Modos de ler

1. Da produção do espaço às práticas espaciais críticas

$31 \quad$ O espaço social

38 A leitura do espaço cotidiano

47 O espaço entre arte e arquitetura: do site-specific à arte útil

58 Práticas espaciais críticas

$69 \quad \mathrm{C} 1$

Coleção de referências

2. Distensões da prática arquitetônica

83 Procedimentos projetuais

91 Programa, indeterminação e usos

110 Projeto e participação

126 Projetos deslocados

143 C2

Coleção de referências
223

3. São Paulo: dois projetos quatro exposições

159 A Marquise do Ibirapuera

162 P33 - Formas únicas da continuidade no espaço (2013)

168 A Marquise o MAM e nós no meio (2018)

177 O Vão Livre do MASP

$182 \quad$ Playgrounds (1969)

$190 \quad$ Playgrounds (2016)

203 C3

Coleção de referências

Considerações finais

229

Referências bibliográficas

239 Índice de imagens 



\section{Introdução}

A disciplina é um princípio de controle da produção de discurso. Ela lhe fixa limites pelo jogo de uma identidade que tem a forma de uma reatualização permanente das regras.

Michel Foucault

"A arte faz, e então você se vira como pode", diz a curadora Chus Martínez a Enrique Vila-Matas. O escritor espanhol foi um dos artistas convidados da Documenta 13 (2012), exposição que acontece a cada cinco anos na cidade de Kassel, Alemanha, e que forma com a Bienal de Veneza e a Bienal de São Paulo uma tríade reconhecida pela relevância de suas proposições e pela longevidade no calendário internacional da arte, hoje abarrotado de eventos e de novas bienais que se multiplicaram nos últimos anos.

Lisonjeado com o convite para participar da exposição que representava o "mito das vanguardas" para sua geração, e desde então para as gerações que a sucederam, dadas as rupturas que ali se enunciavam, Vila-Matas se surpreende com o propósito e teor de sua participação imaginado pela curadora Carolyn Christov-Bakargiev e a cocuradora Chus Martínez: permanecer todas as manhãs, durante três semanas do final daquele verão, sentado a uma mesa em um restaurante chinês, no subúrbio de Kassel, escrevendo, à vista do público, e disponível para intereragir com quem entrasse no restaurante. Entre relato e ficção, ao longo do livro Não há lugar para a lógica em Kassel (2012), o autor discorre sobre os incômodos dessa experiência e quanto a vivência e o contato com outros trabalhos daquela edição da Documenta o afetou.

Esse aspecto provocador, que intercepta outros campos do conhecimento e se expande de modo a experimentar e inventar os meios e o contexto de sua produção, sem amarras profissionais normativas e com uma reatualização permanente de suas regras ${ }^{1}$, é uma característica da arte do

Em $A$ ordem do discurso, uma aula inaugural no Collège France, pronunciada em 1970, Foucault parte da hipótese de que a produção do discurso é controlada, selecionada, organizada e redistribuída por procedimentos, dentre eles as disciplinas, que atuam como um princípio 
século XX, e um princípio que atinge um ponto de inflexão no que diz respeito à produção tridimensional e seus rebatimentos no campo arquitetônico a partir da década de 1960.

Produzindo o efeito sugerido por Martinéz, a arte passa a desafiar seus limites com a arquitetura, não somente pela produção e inserção de objetos que reconfiguram a experiência espacial, mas também por procedimentos conceituais e ações que questionam molduras institucionais, tensionam os códigos de produção e recepção da obra, redefinem protocolos e convocam o uso.

As experimentações artísticas, nesse momento de dissolução do suporte material e do estreitamento de sua ligação com o mundo pela suspenção das fronteiras entre arte e vida, desintegram-se no cotidiano e desencadeiam uma reconexão com o público e com contextos. Configuramse, então, ambientes intersubjetivos que avançam sobre um território reconhecido da prática arquitetônica, do mesmo modo que a arquitetura amplia suas intersecções com a arte a partir da revisão de algumas de suas premissas disciplinares consolidadas.

Mas esse período de intensificação nos trânsitos entre os campos da arte e da arquitetura, durante as décadas de 1970-80, mobilizados por debates compartilhados e por proximidades que marcam a transição da modernidade para a pós-modernidade ${ }^{2}$, parecem refluir para um estado de hipermercantilização da arte e de inflação formal por parte da arquitetura diante do avanço especulativo da economia global nas duas últimas décadas do século XX. Uma dinâmica que se reflete na produção e reprodução do espaço, levando cidades a disputarem investimentos e alavancarem grandes operações urbanas lastreadas por edifícios únicos

de limitação, relativo e móvel, conforme um jogo restrito que o inscreve num certo horizonte teórico e numa prática definida (FOUCAULT, 1999). De modo análogo, e reverberando a provocação de Martinéz, é pertinente notar como o curador Nicolas Bourriaud, em Formas de vida. A arte moderna e a invenção de si (1999), trata da qualidade da insubordinação às normas por parte da pesquisa e prática artística ao longo do século XX, destacando sua qualidade de reunir "um conjunto de práticas destituídas de regra, irredutíveis a normas, cuja pedra de toque se revela difícil de descobrir” (BOURRIAUD, 2011, p. 13).

2 “Há um imenso entrecruzamento de questões teóricas entre a arte e a crítica de arte pós-modernas e a teoria arquitetônica, em grande parte devido à influência dos mesmos paradigmas teóricos (notadamente o pós-estruturalismo) nas duas disciplinas” (NESBITT, 2008, p. 46). 
e programas apoiados numa imagem estrategicamente cultural.

Esse fenômeno, tratado como uma síndrome por Hal Foster $^{3}$ - para quem o arquiteto passou a desempenhar a função de criar a forma escultural e o edifício único como um disseminador do design subordinado às necessidades de consumo e estilo da vida contemporâneos -, tem viés equivalente à imagem alegórica sugerida por Keller Easterling, na qual a arquitetura teria se tornado a "pedra ocasional na água"4, tamanho o grau de distanciamento do arquiteto na construção da realidade urbana contemporânea.

Mas desde a crise financeira de 2008 - cujo estopim é justamente uma bolha do mercado imobiliário alavancado por derivativos financeiros de hipotecas - e seus reflexos ao longo da última década, se intensificam os discursos de que a arquitetura está enfraquecida, com baixo protagonismo nas esferas de decisão e numa maré de escassez de concursos e projetos significativos. Do mesmo modo, há uma expansão de pautas éticas que abordam a precarização das condições de trabalho na construção civil, seu reflexo na profissão ${ }^{5}$, além de críticas às grandes obras autorais inauguradas na primeira década do século XXI. Em contrapartida, se renova a discussão sobre métodos e estratégias de atuação profissional, procurando repensar de forma crítica a

Esse é o assunto do livro Complexo arte arquitetura (2012) que será abordado na seção desta tese intitulada "Prática crítica". Questão que será expandida a partir de textos de Keller Easterling na seção intitulada "Circuitos cruzados" que integra o capítulo 1.

5 É sintomático que um arquiteto como Reinier de Graaf, associado ao Office for Metropolitan Architecture (OMA) - escritório fundado por Rem Koolhaas e que participou ativamente de grandes obras no mundo todo desde o final da década 1980 -, tenha publicado em 2017 o livro Four Walls and a Roof. The Complex Nature of a Simple Profession, no qual aborda o lado nada glamouroso da profissão no âmbito do starsystem internacional, demonstrando como arquitetos devem servir aos poderes que criticam num eterno conflito de interesses em que se veem enredados em ambíguas alianças entre poder público, capital financeiro, lobby de fabricantes e empreiteiros, e para o qual empenham um desproporcional esforço e responsabilidade mediante o menor retorno financeiro dentre os atores que compõem a pirâmide que alavanca esses empreendimentos. Essa circunstância, segundo de Graaf, está desencadeando uma aversão ao risco e um recuo ainda maior dos profissionais em projetos importantes e de grande impacto urbano. Esse mesmo tema é muito bem interpelado e transposto para o ambiente brasileiro por Anália Amorim no texto "Sobre o ato de projetar e construir" (2017) e pelo projeto RioNow coordenado por Ana Luisa Nobre na PUC-Rio. Ambos integram o projeto Contracondutas (2016-2017), que coordenei e dividi a curadoria com Ligia Nobre. 
produção do espaço entre a polaridade contemporânea relegada ao arquiteto urbanista, que ora se depara com a grande obra singular, ora com subprodutos que se alastram como repetição de fórmulas da qual estão distanciados por opção ou por incapacidade de intervir.

É nessa fissura que o espaço reemerge como articulador das discussões sobre múltiplas e possíveis agendas para a arquitetura e para a teoria da arquitetura, a partir de releituras da obra de Henri Lefebvre e de seu esforço epistemológico de constituir uma ciência do espaço. O termo "prática espacial”, apropriado da noção tripartida de espaço ${ }^{6}$ postulada pelo filósofo em A produção do espaço (1974), tem sido empregado com destaque em exposições, seminários e publicações recentes, dado o caráter social e dialético que Lefebvre conferiu à sua elaboração, na qual o espaço é simultaneamente agente e produto de sua produção. Ou seja, o espaço, e consequentemente a arquitetura, moldam a sociedade ao mesmo tempo em que são moldados por ela.

Com essa elaboração, Lefebvre retira do domínio exclusivo dos arquitetos - ou ao menos do que se tinha como a configuração de um claro limite disciplinar na modernidade -, o ato de planejar, desenvolver e manipular espaços, e com isso instaura uma cultura espacial partilhada, produzida e modelada por um número crescente de disciplinas entre arquitetos e urbanistas, geógrafos, sociólogos, legisladores, artistas, entre outros, assim como por não especialistas.

Portanto, os leitores de Lefebvre que adotam e difundem a noção de uma prática espacial a compreendem como uma ação estratégica que revigora a arquitetura a partir de sua expansão para ampliar o contato com disciplinas correlatas, particularmente para ocupar as bordas que a aproximam da arte, permitindo repensar instâncias de atuação além da polaridade entre a obra singular e subprodutos que se alastram à revelia da interferência dos arquitetos.

Para Markus Miessen, um dos editores de uma coleção

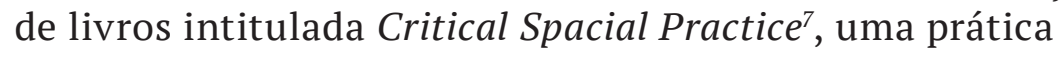
espaço social”.

7 São nove volumes lançados até o momento a saber: What Is Critical Spatial Practice? (2012), de Nikolaus Hirsch e Markus Miessen 
espacial crítica proporciona a expansão das atividades normalmente atribuídas aos arquitetos, e compreende tanto um campo discursivo - curadorias, estruturas institucionais e pesquisas - quanto ações e intervenções propositivas que consideram e mobilizam as realidades sociais em que se inserem. Segundo Miessen (2016, p. 39):

Em termos gerais, dar importância às culturas, ao espaço, e às realidades cotidianas da produção espacial diverge dos discursos normativos arquitetônicos e urbanísticos - passa por uma abordagem mais ampla, ao mesmo tempo em que remete a práticas criativas muito específicas e consolidadas. Isso fornece uma plataforma a partir da qual os discursos familiares à arquitetura e ao urbanismo podem ser expandidos, bem como aponta uma saída para a exploração de práticas alternativas ou híbridas. ${ }^{8}$

Duas questões merecem destaque nessa afirmação. A primeira é a indicação de uma prática alternativa, o que pode ser questionável por justamente reafirmar um modo único de se compreender os campos de atuação disciplinar, fixando-lhes claros limites num momento de importante revisão de paradigmas. A segunda é a configuração com maior clareza do que significa um campo híbrido de atuação entre arte e arquitetura, considerando processos comuns e práticas voltadas à especulação e intervenções no espaço que efetivam uma interterritorialidade capaz de suspender uma suposta dicotomia herdada do período moderno entre uma positividade da arquitetura e sua função social, e a

(Eds.); The Space of Agonism (2012), de Markus Miessen e Chantal Mouffe; Manifesto Architecture: The Ghost of Mies (2014) de Beatriz Colomina; Subtraction (2014) de Keller Easterling; Ickles, Etc. (2014), de Mark von Schlegell; The Roundabouts Revolution (2015), de Eyal Weizman; Disorientation: Bernard Rudofsky in the Empire of Signs (2016), de Felicity D. Scott; The Proposal (2016) de Jill Magid; e Displacements: Architecture and Refugee (2017), de Andrew Herscher.

No original: "Broadly speaking, the consideration of cultures, of space, and of everyday realities of spatial production digresses from normative architectural and urbanist discourses - it shifts to a more general approach, but, at the same time, one that addresses very specific, embedded creative practices. This provides a platform from which provides discourses familiar to architecture and urbanism can be expanded, as well as finding outlets for the exploration of alternative and basterdized forms of practice”(MIESSEN, 2016, p.31). 
negatividade da prática artística como campo não utilitário e autônomo de experimentação.

Há um embaralhamento destas instâncias, o que é evidente quando passada em revista algumas edições recentes de bienais de arte, bienais de arquitetura, prêmios e publicações nas quais nos deparamos com práticas espaciais mais complexas do que as categorias tradicionais dão conta de sistematizar. Refiro-me, por exemplo, ao prêmio Turner ${ }^{9}$ que, em 2016, gerou revolta em parte do sistema de arte britânico - que chegou a declarar a morte do tradicional prêmio diante de um equívoco de categorias ${ }^{10}$ - ao conceder o grande prêmio do júri ao Assemble ${ }^{11}$, um grupo que reúne profissionais de diversas formações.

Dois anos mais tarde, este mesmo prêmio selecionou, entre os quatro finalistas que integram uma exposição na Tate Britain, em Londres, o trabalho do Forensic Architecture, um laboratório transdisciplinar de pesquisa e atuação em causas de violação dos direitos humanos coordenado pelo arquiteto Eyal Weizman sob a moldura institucional do Goldsmiths College, University of London. ${ }^{12}$

No ambiente nacional, de modo semelhante, a

O Prêmio Turner (referência ao pintor britânico J.M.W. Turner) é organizado pela Tate Gallery e realizado anualmente, desde 1984, para premiar e estimular a produção de artistas, bem como ampliar o conhecimento do público acerca da produção contemporânea britânica. Por isso, a cada edição, uma exposição é realizada para apresentar os quatro finalistas indicados ao prêmio. Em que pese as Instituições e financiadores, e o impacto que isso tem sobre as escolhas, o prêmio Turner procura formar um júri diverso a cada edição. Nas últimas três edições compuseram o júri o artista Tom McCarthy, os editores das revistas ArtReview e Frieze, curadores do Walker Art Center's of Moving Image de Minneapolis, do Kunsthalle Basel, do Henry Moore Institute of Sculpture Studies e do espaço de arte independente londrino Showroom, entre outros.

Ver por exemplo o destaque que mídia inglesa deu ao fato. Disponível em: https://www.theguardian.com/artanddesign/2015/dec/08/assembleturner-prize-architects-are-we-artists. Acesso em: 8 jan. 2018.

Assemble traz em seu significado um duplo sentido, traduzido como uma congregação, mas também como a construção de algo pela junção das partes. O grupo intensifica os questionamentos acerca de ações colaborativas com intervenções na esfera pública, e foi criado em 2010 por dezoito pessoas com diversas formações - arquitetura, filosofia, história, técnicos em construção e teatro, o que concede um caráter performático às suas ações. 
Associação Paulista dos Críticos de Arte (APCA) ${ }^{13}$ premiou, também em 2016, Carmen Silva, liderança do Movimento Sem Teto do Centro (MSTC), na categoria arquitetura e apropriação urbana, pelo projeto de residências artísticas realizado a partir da parceria do movimento com artistas e curadores na ocupação do Edifício Cambridge, no Centro de São Paulo. Um fenômeno que, desde então, tem se desdobrado na atuação de inúmeros agentes culturais com o MSTC e a presença da Ocupação Nove de Julho como um notável polo irradiador do debate sobre direito à moradia como prática de cidadania - o que confere ao movimento um reconhecimento internacional ${ }^{14}$, dada sua atuação inovadora como impulsionadora de transformação urbana.

Outro exemplo ainda é o trabalho da dupla de arquitetos Rael San Fratello, que realizou uma intervenção temporária instalando um conjunto de gangorras <imagens 1a e 1b p.20> nas frestas de um gradil no grande muro de divisa entre Estados Unidos e o México, em julho de 2019. Apoiada na base do gradil, a gangorra cor de rosa uniu crianças de ambos os lados pela brincadeira e ampliou a visibilidade do impacto físico e social que a linha de divisa, reflexo de um desenho num mapa, é capaz de gerar ao separar uma cidade ao meio. Essa intervenção, que se tornou um dos assuntos mais comentados no mundo pelo modo como "viralizou" nos meios digitais, foi realizada como um manifesto cuja intenção era justamente chamar a atenção para um projeto maior chamado Bordelands (2009-), e que se iniciou como um estúdio junto da Universidade da Califórnia, em Berkeley, para tratar dos impactos do muro nas cidades fronteiriças.

Trata-se de um procedimento semelhante ao Cinerolium (2010), desenvolvido pelo Assemble, quando, durante as férias de seus empregos formais, o grupo reuniu mais de cem voluntários para erguer um cinema temporário sob a

O júri foi composto por: Abilio Guerra, Fernando Serapião, Francesco Perrotta-Bosch, Gabriel Kogan, Guilherme Wisnik, Hugo Segawa, Luiz Recaman, Maria Isabel Villac, Mônica Junqueira de Camargo e Nadia Somekh. universidades e outros agentes socioculturais foi apresentado com destaque na terceira edição da Bienal de Chicago sob o título... and Other such Stories (2019). Uma edição na qual a equipe curatorial formada por Sepake Angiama, Paulo Tavares e a diretora artística Yesomi Umolu preocupou-se em repensar radicalmente os modos de espacialização das paisagens urbanas a partir das estruturas de poder dentro das quais a arquitetura opera. 
1a Teeter-Totter Wall [Muro Oscilante] (2019)

Ciudad Juarez-México/El Paso-EUA

Rael San Fratello

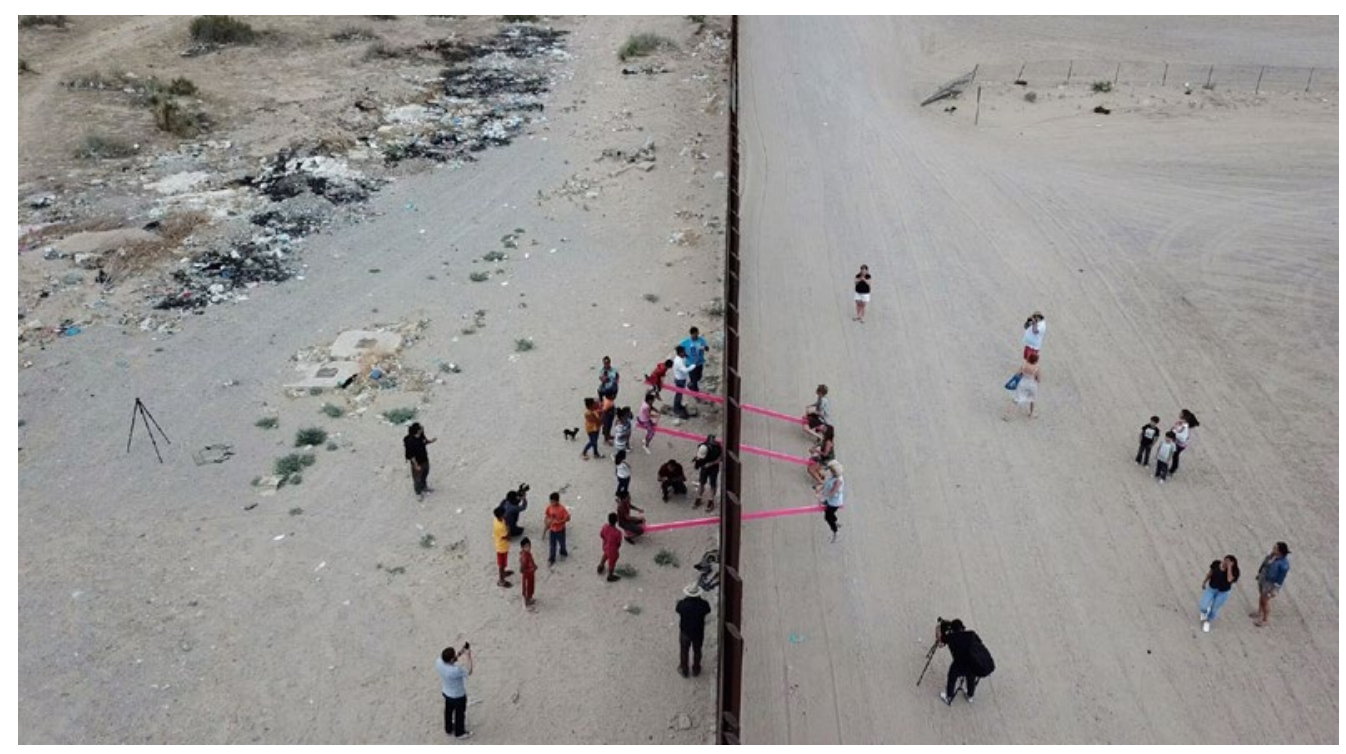

$1 b$

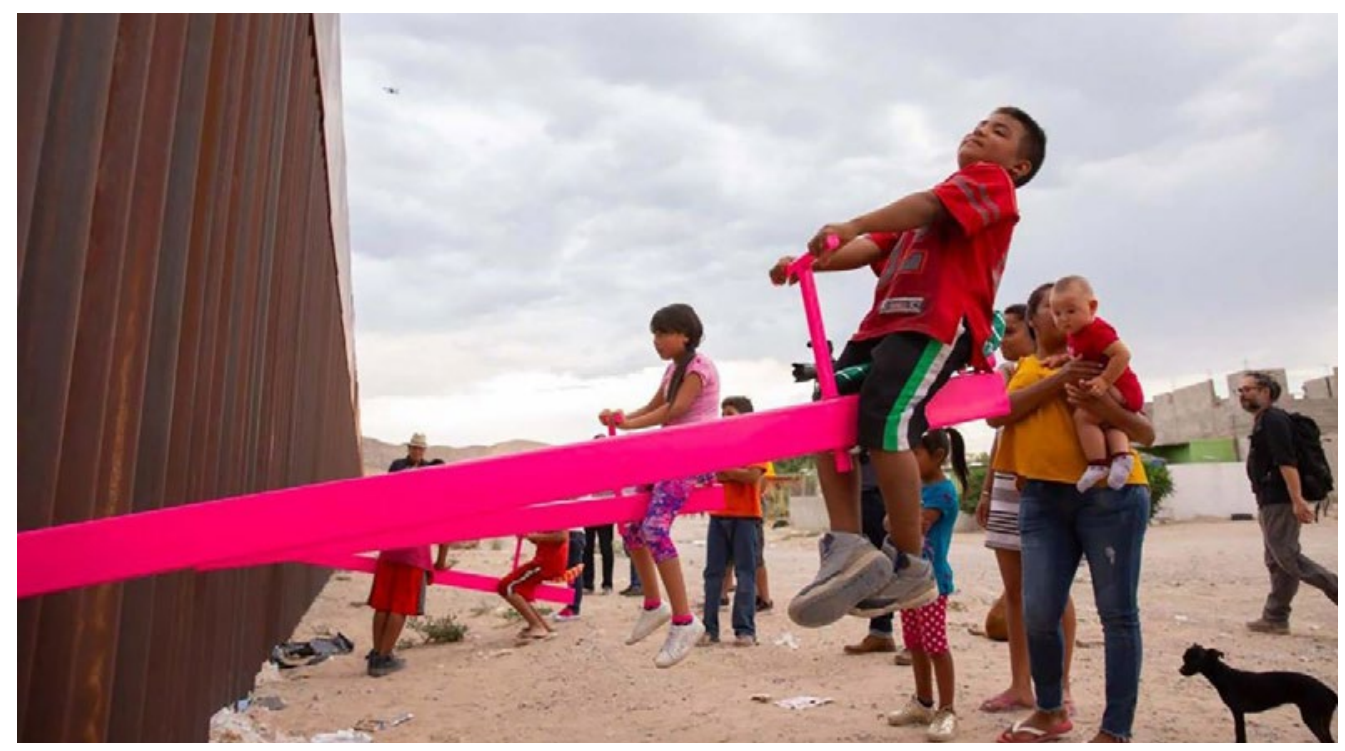


2a The Cineroleum (2010)

Londres

Assemble

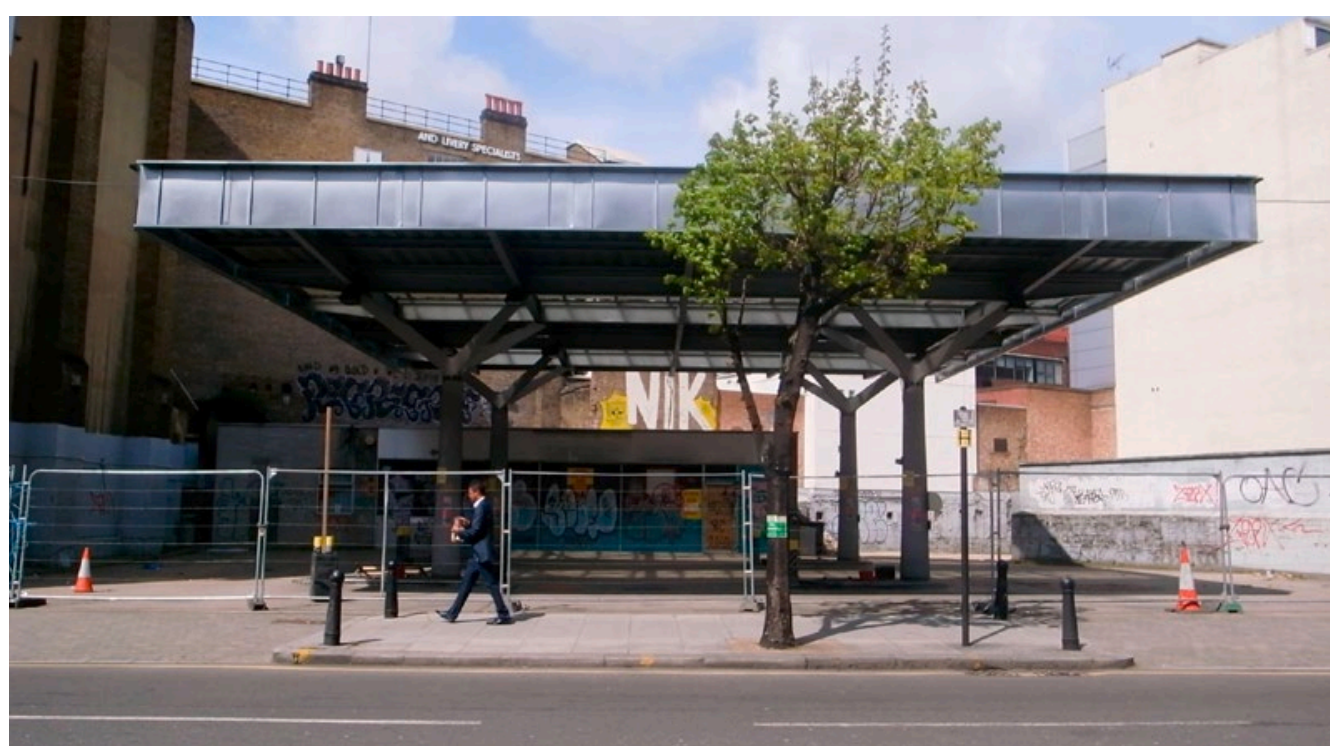

$2 b$

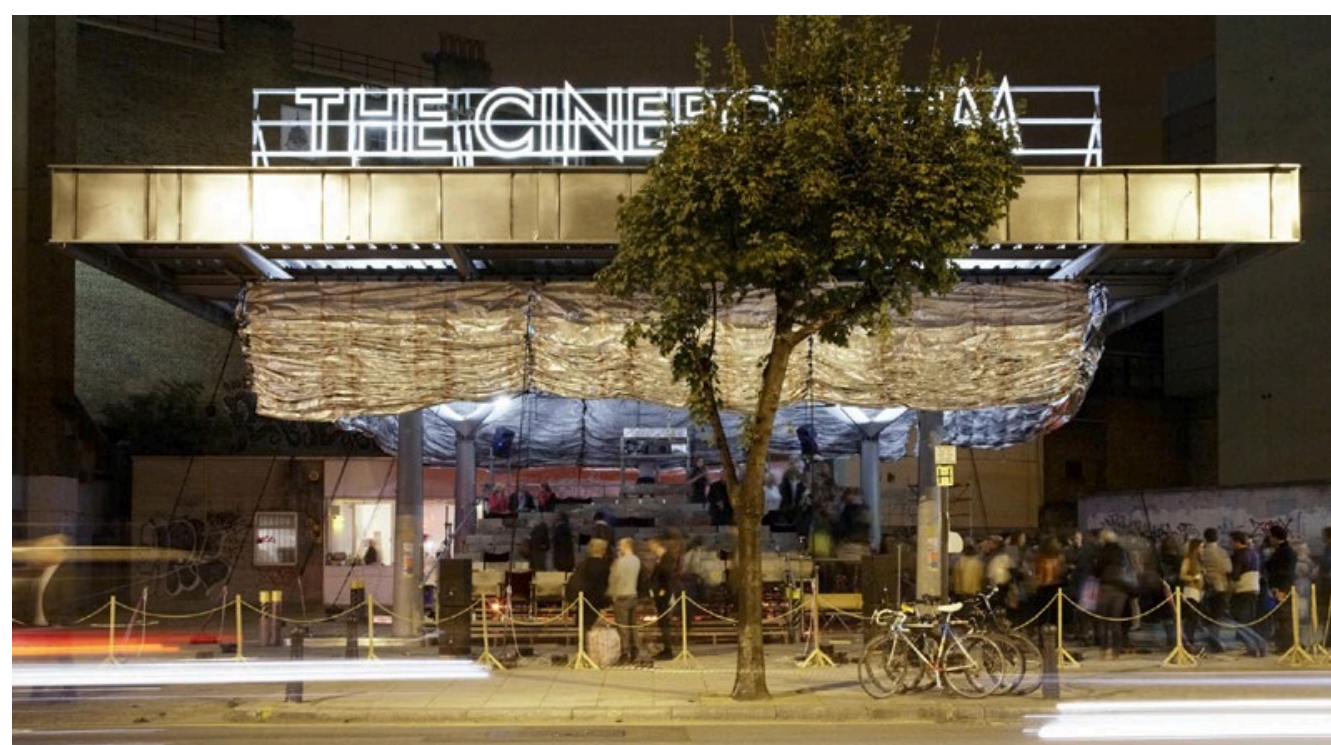


estrutura de um posto de gasolina desativado em Londres, utilizando materiais reciclados e doados <images $2 \mathrm{a}$ e $2 \mathrm{~b}$ p. 21>. Com essa intervenção, pretendiam chamar atenção para o potencial de uso dos inúmeros postos de gasolina desativados que, localizados em áreas de rápido crescimento e valorização, tornam-se peça chave na disputa por espaços de lazer em zonas de intensa especulação imobiliária ${ }^{15}$.

Esse enfrentamento mais direto da realidade, por meio de intervenções que se distanciam do ideal do edifício icônico e da autoria individual para adotar um engajamento com contextos específicos, e com isso mobilizar camadas históricas, sociais e políticas como vetor de ação, constitui uma clara amostragem do quanto categorias convencionais encontram-se desgastadas, resultando numa simplificação das análises de trabalhos que cruzam campos para pensar e agir sobre a transformação do espaço. Um modo de também se repensar a produção da arquitetura que já havia sido anunciada nos anos 1960, de acordo as análises que essa tese propõe sobre os trabalhos de Yona Friedman, Cedric Price, Aldo Van Eyck, Lina Bo Bardi, Venturi e Scott Brown, entre outros. Segundo Denise Scott Brown, desde o final dos 1950, a influência do Team 10 se fazia sentir e, particularmente no contexto inglês de sua formação, era evidente a importância do Independet Group ${ }^{16}$ e o modo como apresentavam um alargamento de seu território de atuação pela aderência ao entorno próximo, às transformações sociais e a pop art, proporcionando uma transição do espaço idealizado para um espaço praticado ${ }^{17}$.

O Cinerolium, assim como outro trabalho do Assemble, foram assunto de um ensaio escrito por mim e publicado na revista Ara Ymã $n^{\circ} 4$ - Espaços em movimento (2018) - com o título "Participação entre campos”.

Grupo de artistas, arquitetos, escritores e críticos que se reuniu no Institute of Contemporary Arts (ICA), em Londres, e que criticava o caráter elitista e distanciado da arte moderna para aproximar a cultura popular, formulando questões que desencadearam o nascimento da pop arte inglesa. Integraram o grupo os artistas Richard Hamilton, Nigel Henderson, John McHale, Sir Eduardo Paolozzi e William Turnbull, os críticos Lawrence Alloway e Rayner Banham, e os arquitetos Colin St John Wilson e Alison e Peter Smithson.

Essas questões atravessam a entrevista que o casal Denise Scott Brown e Robert Venturi concedem ao curador Hans Ulrich Obrist e ao arquiteto Rem Koolhaas publicada no livro The Harvard Design School Guide to Shopping(2001) com o título de "Relearning from Las Vegas. An Interview with Denise Scott Brown and Robert Venturi Brown”. Segundo Scott Brown (2000, p.611): “Na Inglaterra, no início dos anos 1950, os Smithsons e outros membros do Independent Group estavam dizendo a mesma coisa: 
A "luz da realidade cotidiana que não brilhava na brancura ascética da imaginação”, como descreve o autor J. G. Ballard (2009, p. 170), impactado pela exposição This is Tomorrow $(1956)^{18}$, conforme relatado em seu livro de memórias Milagres da vida (2009), teria escancarado tanto a arte quanto a arquitetura para uma contaminação pela cultura de massa e pelas ruas.

É possível notar que, nesse processo, à medida que a arquitetura se descola de uma visão ortodoxa do projeto, torna-se mais evidente a reinterpretação e o emprego de procedimentos comuns à prática artística das neovanguardas, com a valorização de etapas processuais, a mobilização de camadas conceituais e discursivas, a ampliação de circuitos de publicização, o desenho de táticas temporárias ou de revisões na tradicional prática projetual que recaem principalmente sobre o questionamento do programa de necessidades em sua relação e impacto em contextos específicos. Ou seja, são atividades cada vez mais determinadas por um campo interdisciplinar, cujos produtos são resultado de processos específicos que envolvem produção e recepção, e não apenas o objeto formal, o que se desdobra também num campo deslocado da prática, não como mimese, mas como ampliação e problematização da própria prática.

Da mesma forma como as atividades associadas à arte questionam o que a arte pode ser, ao problematizar suas práticas e expandi-las, seria possível transpor para o campo da investigação arquitetônica uma esfera especulativa, e de problematização, análoga à dialética entre "site" e "non-site", conforme a formulação de Robert Smithson?

Smithson desenvolve e lapida a relação de rebatimentos e ambiguidades entre o "sítio” e o "não-sítio” em diversos trabalhos e textos, corroborando seu modo de atuar que entrelaça pensamento e prática. De modo simplificado, seria

veja a vida nas ruas do extremo leste de Londres.[...]Nossas visões sobre a arquitetura derivam tanto dessas visões sociais e do desenvolvimento delas durante os movimentos sociais da década de 1960, como na pop art.”

18 Realizada na galeria Whitechapel, em Londres, essa exposição é considerada um marco para a pop art, e incluía instalações desenvolvidas em colaboração por equipes que deveriam ser formadas por arquitetos, pintores e escultores apresentando sua visão de futuro. A instalação de Eduardo Paollozi e dos arquitetos Alison e Peter Smithson apresentava uma cabana pós apocalipse nuclear, e os objetos necessários para a sobrevivência nessas condições. 
possível afirmar que o sítio é onde o trabalho acontece, e o não-sítio é constituído pelas camadas discursivas e de documentação desse trabalho, reunidas e organizadas em outro meio, mas que guardam uma relação de continuidade com o sítio.

Mas há um espelhamento entre o sítio e o nãosítio que não necessariamente se baseia numa relação de representação fiel da realidade. Smithson alterna constantemente os sinais entre real e metáfora, teoria e prática, e estabelece rebatimentos entre dentro e fora do espaço expositivo, pelo emprego e experimentação de diversos meios de linguagem. Enquanto o sítio "caracteriza o mundo em si, com suas complexidades e possibilidades, vastas e remotas - evocativas mas sem logos" (FLAM, 1996, p. xvii, tradução minha $)^{19}$, o não-sítio destaca e desloca o sítio para um campo de elaboração mental sobre o espaço físico, no qual este ganha vida própria e se torna uma forma de discurso, podendo inclusive assumir diversas formas, até mesmo a de "uma imagem tridimensional abstrata que ainda assim representa o local real. É por meio dessa metáfora tridimensional que um local pode representar outro local que não se assemelha a ele. Portanto o não-sitio" ${ }^{20}$ (SMITHSON, apud FLAM, p. 364, tradução minha).

Seria simplista, nesse caso, assumir que os desenhos processuais para elaboração de um projeto se enquadram na premissa do não-sítio, ao passo que o projeto construído poderia equivaler à sua realização e, portanto, ao sítio do trabalho. Tal constatação não exclui pensar que toda documentação preliminar, como croquis, anotações de campo e detalhes executivos, possa ser deslocada para um campo discursivo, mas o interesse, nesse caso, recai sobre como a arquitetura mobiliza seus códigos institucionais e seus modos de operar de um ponto de vista crítico, constituindo não-sítios metafóricos, fictícios e especulativos, nos quais possa elaborar sua produção desde um campo mais diverso de prática.

No original: "The site represents the world itself, the unedited text with all of its complexities and possibilities, vast and remote - evocative but without logos". 
Segundo a arquiteta Peggy Deamer ${ }^{21}$, a noção de prática deve ser compreendida em um contexto crítico, e que não equivale à noção de profissão mas ao "ato de ensaiar um comportamento; um método de aprender e adquirir experiência; e uma estratégia para a realização"(DEAMER, 2011, p.161). O que impacta nos discursos consolidados de modo positivo, transferindo o debate sobre inovação, que sempre esteve atrelado à teoria ou à forma - como dois polos do pensamento especulativo entre a academia e a edificação -, para um campo especulativo ao mesmo tempo utópico e com aderência ao real.

Assim, o termo prática espacial crítica, e sua absorção recente pela arquitetura, será examinado, a princípio, pela sua capacidade de abarcar deslocamentos desde o interior desse campo disciplinar, explorando uma disposição para diluição a diluição de suas fronteiras.

Sem negar saberes específicos, mas questionando lógicas fundamentais da disciplina, tais práticas promovem uma indiscutível atualização de regras, agindo inclusive sobre a prática projetual, sem negá-la, mas tensionando dinâmicas de controle e poder, assim como o papel desempenhado pelos usuários da arquitetura. Tal distensão, que pode ou não implicar na criação de objetos materiais, compreende uma ampliação de estratégias de ação, sem abrir mão de um compromisso propositivo, com impacto transformador sobre a realidade espacial contemporânea. The Architect as Worker: Immaterial Labor, the Creative Class, and the Politics of Design (2015), Architecture and Capitalism: 1845 to the Present (2013), entre outros, e é fundadora da plataforma Architecture Lobby, um grupo que defende o valor do projeto arquitetônico e do trabalho. Disponível em: http://architecture-lobby.org/.Acesso em 15 fev. 2020. 


\section{Modos de ler}

A organização do volume procura privilegiar os aspectos brevemente apresentados nessa introdução, dando a eles a amplitude necessária ao longo de seus três capítulos. Cada capítulo é acompanhado de um caderno de referências que reúne as imagens e as análises de caso selecionadas e reportadas no texto .

Esses cadernos, ao final de cada capítulo, são compostos por "fichas" que associam as imagens a textos complementares, podendo ser acessados para amparar a narrativa principal e oferecer uma leitura concomitante e aprofundada de aspectos desses trabalhos assim como da prática de seus autores. São análises que abrem um plano ampliado de interpretação. No entanto, esses cadernos também podem ser lidos de modo independente, uma vez que seus textos sinópticos, como legendas em uma exposição, fornecem um segundo tempo de apreciação que se dá também pela vizinhança entre os trabalhos selecionados e todas as possíveis inter-relações que possam ser trilhadas pelo leitor.

Importante ressaltar que, longe de abarcar uma totalidade de exemplos pertinentes aos assuntos abordados por esta tese, há um recorte orientado pela qualidade e importância dos trabalhos selecionados em relação à discussão proposta, num contexto global. No entanto, é necessário também reconhecer que a seleção é fruto de meu interesse em certas questões que, na medida em que me instigam no exercício do ensino e na prática entre os campos da arte e da arquitetura, me motivaram a escrever essa tese.

O primeiro capítulo contempla os textos que embasam a tese e o processo desencadeado a partir dos anos 1960, no qual arte e arquitetura se aproximam e diluem suas fronteiras mobilizando estratégias, procedimentos e circuitos que se sobrepõem e estabelecem correspondências nas práticas exercidas por esses campos. Do ponto de vista da teoria da arquitetura, a noção de espaço social elaborada por Henri Lefebvre e o cotidiano tratado por Michel de Certeau são questões centrais, dada sua atualização por parte da crítica arquitetônica. Do ponto de vista da teoria e crítica da arte, o debate em torno das práticas site-specific e seus desdobramentos na esfera das relações, por meio de processos participativos e socialmente engajados, ampliam um horizonte de leituras cruzadas com a intensificação de provocações que mobilizam o valor de uso. 
O segundo capítulo parte de estudos de caso do campo arquitetônico para demonstrar como procedimentos empregados na elaboração de projetos distende a prática, orientando-a para uma valorização de conceitos e processos, tanto quanto do objeto edificado. Projetos deslocados para um campo discursivo ou de "não-sítio", com implicação direta na revisão dos tradicionais meios de representação arquitetônica e seus circuitos de publicização também serão examinados.

O último capítulo situa esse debate na cidade de São Paulo, recorrendo a duas arquiteturas que, em razão do alto grau de indeterminação de seus programas, foram simbolicamente apropriadas e intensamente utilizadas pela população: a Marquise do Ibirapuera e o Vão Livre na Av. Paulista. Avizinhadas por duas importantes instituições culturais da cidade, o MAM e o MASP, quatro exposições produzidas por esses museus possibilitam uma investigação sobre como essas infraestruturas, seus projetos e sua apropriação estabelecem interface com a cidade, com seus públicos e usos.

Ao final, teço algumas considerações a propósito desse percurso diante das potencialidades e fragilidades que um campo partilhado entre arte e arquitetura possa representar enquanto reconfiguração nas maneiras de fazer, pensar e vizibilizar essas práticas estéticas e políticas, em sua implicação com a produção do espaço. 

1.

Da produção do espaço às práticas espaciais críticas 



\section{O espaço social}

O espaço está ligado ao território, à história de um lugar, às suas características geográficas e aos seus hic et nunc.

Antoni Muntadas

Trabalhos que cruzam práticas e desafiam categorias, particularmente no que diz respeito aos trânsitos entre os campos da arte e da arquitetura, têm, nos anos 1960, um importante ponto de inflexão. Enquanto a noção moderna de escultura era explodida pela sua diluição no entorno e no espaço - a arquitetura dos museus e galerias, a cidade ou a vasta paisagem das grandes porções territoriais -, a experiência estética deslocava-se da obra de arte autônoma para o lugar e seu contexto. Paralelamente, o esgotamento da ortodoxia funcionalista e racional era tensionada por uma nova geração de arquitetos que, com um interesse social renovado, apostava nas dinâmicas humanas, na cidade e sua complexidade, no real e na cultura popular como antídotos à abstração moderna.

Inicia-se nesse período, portanto, um progressivo estreitamento dos limites disciplinares. Na arte observase a rejeição do meio específico, a renúncia da autonomia da forma e a tendência de dissolução da arte na vida, ao passo que a arquitetura acusa o esgotamento de um modelo totalizante da realidade traduzida pela forma projetada como único elemento responsável pela ordenação das coisas no espaço $^{22}$.

Nesse sentido, as noções de espaço elaboradas nesse mesmo período pela geografia urbana, por teóricos sociais e culturais, contribuem e reverberam nas leituras cruzadas que investigam intersecções entre arte e arquitetura, à medida que essas práticas se expandem para intervir

Ainda que ao longo do período pós-moderno, e mesmo no início dos anos dois mil, esse questionamento no campo da arquitetura tenha refluído e, em diversos momentos, resultado em uma exacerbação da forma de modo alegórico, reforçando a autonomia da obra, como será tratado no início do segundo capítulo dessa tese. 
inventiva e criticamente no cotidiano e no tecido social. Dado o interesse pela maneira como o termo "prática espacial”, elaborado originalmente por Henri Lefebvre, adquire hoje um protagonismo, cabe aqui um exame de sua origem e posterior utilização no contexto de uma crítica que aproxima a arquitetura da arte, recorrendo à investigação de práticas cada vez mais próximas e compartilhadas entre ambas, que, ao se expandirem, estabelecem um campo mais amplo e interdisciplinar de ação sobre o espaço.

Se a noção de espaço sempre esteve presente nas discussões do campo arquitetônico, sendo considerada, ao longo do século XIX, e através do entre guerras, uma característica essencial por historiadores modernos como Nikolaus Pevsner, Sigfried Giedion e Bruno Zevi ${ }^{23}$. Posteriormente há uma mudança gradual no sentido de sua interpretação que influencia e expande a agência da prática arquitetônica.

Em um artigo no qual se propõe a elaborar uma revisão historiográfica sobre o tema, Anthony Vidler ${ }^{24}$ (1999, p. 483) conclui que "a resistência disciplinar às influências intelectuais externas é fortemente evidenciada na história da arquitetura", e ainda que tenha sido questão determinante ao longo do período moderno, seria recente a concepção de um estudo crítico mais abrangente e multidisciplinar sobre o espaço no campo arquitetônico.

A superação do debate moderno acerca do dualismo entre forma e função, e o alargamento da definição de espaço - até então compreendido como abstração geométrica,

Nikolaus Pevsner, em Os Pioneiros do Movimento Moderno. De William Morris a Walter Gropius (1936), cunha o termo "movimento moderno" e o desdobra como resultante de um processo histórico no qual o espaço surge como vocação para a manipulação formal, uma vez superados os estilos do passado. Sigfried Giedion, em Espaço, Tempo e Arquitetura: $o$ Desenvolvimento de uma Nova Tradição (1960), identifica três estágios de evolução na concepção do espaço ao longo da história da arquitetura ocidental, um da exterioridade volumétrica da antiguidade, outro escavado e interno a partir do período medieval, e um terceiro no século $\mathrm{XX}$, que nega a perspectiva de ponto de vista único e sobrepõe planos e transparências. Bruno Zevi, em Saber ver Arquitetura (1948), apresenta o espaço como protagonista da arquitetura, ainda que esta não se esgote com experiência espacial arquitetônica e se amplie para a cidade.

Anthony Vidler é historiador e crítico de arquitetura, professor e diretor da Irwin S. Chanin School of Architecture, na Cooper Union, em Nova Iorque, e autor de The Architectural Uncanny: Essays in the Modern Unhomely (1992), Warped Spaces. Architecture and Anxiety in Modern Culture (2000), e Noah's Ark. Essays on Architecture (2016), entre outros. 
vazio resultante da massa construída ou composição formal de volumes distribuídos num campo homogêneo -, só aconteceria, segundo Vidler, a partir de uma mudança de enfoque marcada pelo trabalho de Manfredo Tafuri, que se opõe a uma análise formal e "expande a atenção para um âmbito externo à arquitetura e à arte, incluindo a história política, social, cultural e econômica, ao mesmo tempo em que as examinava criticamente” (VIDLER,1999, p. 438).

Ao responsabilizar os historiadores da arquitetura moderna por uma análise operativa e demasiadamente filiada às ideologias em curso naquele período, Vidler reconhece uma mudança de paradigma acerca do espaço a partir dos anos 1990, quando se amplia a disposição para o reconhecimento de trabalhos originados em outros campos de estudo, particularmente aqueles que têm a arquitetura como disparadora de seus questionamentos. São casos exemplares a leitura da dimensão espacial do poder e das possíveis heterotopias por Michel Foucault (1926-1984) - em Vigiar e punir(1975) e De outros espaços (1967) -, e o estudo crítico sobre os modos de produção do espaço por Henri Lefebvre (1901-1991).

O filósofo Henri Lefebvre publicou $A$ produção do espaço em 1974. Com este livro, concluiu seu esforço em formular uma teoria sobre o espaço ${ }^{25}$, iniciado em $O$ direito à cidade, de 1968, e desenvolvido ao longo de seis livros nos quais abordou a cidade como grande laboratório do homem. Informado por contribuições externas à filosofia, e buscando superar o senso cartesiano do termo, Lefebvre pretendia conformar uma epistemologia do espaço como um campo de conhecimento múltiplo, atravessado por várias dimensões, e impossível de ser apreendido como síntese ${ }^{26}$.

Ainda que existam divergências entre estudiosos e comentadores da sua obra, segundo Lukas Stanek, são seis as publicações onde Lefebvre formula sua teoria da produção do espaço: Le droit à la ville (1968), "La Révolution urbaine (1970), Du rural à l'urbain (1970), Espace et politique (1972), La Pensée marxiste et la ville (1972) e a La production de l'espace. Destes, apenas O Direito à Cidade e $A$ Revolução Urbana tiveram edições traduzidas no Brasil. A produção do espaço (1974) não possui tradução publicada no Brasil.

26 Lefebvre combatia a ideia de uma síntese mas pensava em termos de uma unidade de pensamento sobre o espaço. Em uma passagem da conclusão de $A$ produção do espaço sobre a exaustão de recursos com consequências ambientais, é possível verificar tanto a condição dialética de sua proposta quanto seu entendimento de unidade: "Um bom número de disciplinas - ecologia ou demografia, geografia ou sociologia 
A virada espacial empreendida por Lefebvre é consequência de um projeto de continuidade do método dialético de Marx aplicado à alienação do mundo moderno que, tendo a vida cotidiana e as cidades em expansão como seu objeto de estudo e também como potencial condição emancipadora, permite um deslocamento da análise do processo produtivo do capital da fábrica para a cidade.

David Harvey, no posfácio da tradução inglesa de A produção do espaço (1991), relaciona alguns fatores biográficos na formação de Lefebvre que se refletem em seu modo de pensar. Além do impacto dos acontecimentos históricos marcantes do início do século XX - a Revolução Russa (1917) e a Primeira Guerra Mundial (1914-1918) -, de sua formação em filosofia na Sorbonne e da filiação ao Partido Comunista Francês, foi uma experiência como taxista em Paris, ao longo de dois anos, nos anos 1920, que teria sido determinante e "o afetaria profundamente" 27 (HARVEY, 1992, p. 426). Essa experiência teria aguçando sua percepção sobre a natureza do espaço e seu reflexo na vida urbana, produzindo um engajamento singular com o cotidiano. Não à toa, o cotidiano mobiliza suas pesquisas empíricas e aplicações práticas ao longo da carreira como pesquisador e professor em Strasbourg (1961-1965) e Nanterre (1965-1973), onde ajudou a fundar o Instituto de Sociologia Urbana, que também presidiu.

Esse processo o conduz à formulação de que o espaço é um fenômeno social e, como tal, é produto e simultaneamente agente do processo de sua produção. Uma formulação que deriva da percepção de que, por volta de 1910, ocorre uma significativa mudança histórica sinalizando uma interdição do espaço absoluto e o surgimento de um espaço abstrato, opressivo e universal. $\mathrm{Ou}$ seja, um espaço homogeneizado pelo mercado e pelo Estado,

- descreve esses resultados, sem se remeter às causas e razões, como sistemas parciais. O que nós buscamos fazer aqui é reunir causas e feitos, consequências e razões, de uma maneira que seja possível transcender divisões entre domínios científicos e especializações e propor uma teoria unitária. [...]A concepção teórica com a qual tentamos trabalhar não aspira um status de 'totalidade completa', nem de síntese, [...] mas reconectar elementos que foram separados” (LEFEBVRE, 1991, p.413).

27 No original: “... two years earning a living as a taxi driver in Paris, (an expirience wich deeply affected his thinking about the nature of space and urban life), kept him from any temptation to an ivory-tower conception of philofical work". 
que se impõe da escala global para a escala local, acentuando as diferenças sociais que se manifestam espacialmente.

Essa mudança de perspectiva proposta por Lefebvre resulta de seu procedimento multidisciplinar e crítico da modernidade, o que faz com que o debate acerca da condição pós-moderna, a partir dos anos 1980, repercuta seu trabalho em diversos campos de estudo, como na Geografia, campo no qual Edward Soja e David Harvey são autores de destaque, na crítica cultural, com Fredric Jameson, na Sociologia, com Manuel Castells, e também no ambiente acadêmico brasileiro por meio da leitura e disseminação de seu pensamento no Departamento de Sociologia da Faculdade de Filosofia, Letras e Ciências Humanas da Universidade de São Paulo (FFLCH-USP), pelo professor emérito José de Souza Martins.

Mas a atualidade de suas proposições reverbera em publicações, seminários e exposições recentes, que referenciam seus escritos, principalmente após a crise financeira de 2008, um marco de transição no cenário global, quando se intensificam as inquietações sobre o esgotamento das possibilidades de expansão dos meios de produção.

Os rebatimentos dessa crise no cenário sociopolítico e ambiental é particularmente sensível diante da condição urbana hoje, uma vez que a congestão das metrópoles contemporâneas, onde vive 55\% da população mundial com projeções de que esse número chegue a $66 \%$ até $2050^{28}$ -, tornam ainda mais agudas as disputas espaciais e a importância de ações estratégicas para o enfrentamento dos efeitos da globalização.

Diante dessa conjuntura, o emprego de termos como "prática espacial”, “direito à cidade” e derivações de outros conceitos lefebvrianos, como (re) "produção do espaço" 29 , são atualizados na tentativa de abarcar trabalhos nos quais os limites tradicionalmente reconhecidos da prática arquitetônica são ampliados, seja pela valorização

Relatório produzido pela Divisão das Nações Unidas para a População por seu Departamento dos Assuntos Econômicos e Sociais (DESA), demonstra que a população mundial é cada vez mais urbana e que em 2019, prevê-se que uma em cada três pessoas habite em cidades com pelo menos meio milhão de habitantes. In: https://news.un.org/ pt/story/2018/10/1645482 (consultado em 01/07/2019 12:09). 
dos processos para sua realização, pelo reconhecimento mais atento dos contextos nos quais se inserem, seja pela tentativa de ampliar as instâncias de participação e engajamento dos diversos agentes envolvidos em sua produção, particularmente na esfera pública e urbana, na qual encontram-se imbricados de modo mais explícito.

De acordo com o modelo teórico elaborado por Lefebvre em A Produção do Espaço, "prática espacial” é uma das três manifestações dialeticamente relacionadas e intersecionadas entre si que compõem sua noção de espaço inferida por meio de outra tríade empiricamente deduzida: o que é percebido, o que é concebido e o que é vivido espacialmente.

Assim, a “prática espacial” seria a esfera visível e legível do espaço, a resultante reconhecível dos fatores implicados na produção e reprodução do espaço e o regulador essencial da vida cotidiana, onde se sobrepõem e se conectam espacialidades e escalas distintas. Como expressão que engloba a produção e a reprodução do espaço, a prática espacial oferece também as "ferramentas para o pensamento e para ação” (LEFEBVRE, 1991, p. 26). Segundo Lefebvre,

\begin{abstract}
A prática espacial de uma sociedade origina esse espaço; pressupõe e propõe esse espaço em uma interação dialética; produz lenta e seguramente enquanto domina e se apropria desse espaço. De um ponto de vista analítico, a prática espacial de uma sociedade é revelada pela decifração de seu espaço. (LEFEBVRE, 1991, p. 38, tradução minha). ${ }^{30}$
\end{abstract}

Outra manifestação, o “espaço de representação”, se refere ao espaço vivenciado no qual, a partir do mundo físico, questões simbólicas se manifestam e são assimiladas, ou seja, trata-se do espaço elaborado pela prática de alguns artistas, escritores e filósofos que se dedicam a descrevêlo sem qualquer outra aspiração que não a da descrição (LEFEBVRE, 1991, p. 39). A "representação do espaço" complementa a tríade dialética, e concerne ao espaço

No original: "the spatial practice of a society secretes that's society's space; it propounds and presupposes it, in dialectical interaction, it produces it slowly and surely as it masters and appropriates it. From the analytic standpoint, the spatial practice of a society is revealed through the deciphering of its space". 
conceituado e concebido por planejadores e tecnocratas, o que abarca os procedimentos cartográficos e as normativas técnicas da representação arquitetônica e urbanística. Como exemplificado por Lefebvre (1991, p. 45, tradução minha):

Representações do espaço conseguem por vezes combinar ideologia e conhecimento desde dentro da prática sócio espacial. A perspectiva clássica é uma perfeita ilustração dessa condição. O espaço dos planejadores de hoje, cujo sistema de localização determina uma exata localização para cada atividade, é outro caso em questão ${ }^{31}$.

Ou seja, as técnicas de representação do espaço descritas por Lefebvre, desde então apenas migraram para um sistema digitalizado de produção, no entanto seguem informadas por abstrações parciais da realidade e convenções tridimensionais elaboradas no século XVIII. O que se altera, como já enunciava o autor, é a posição do observador, distanciado, e a vertiginosa ambiguidade entre instâncias de visibilidades e invisibilidades, e de estatutos de ficção e realidade geradas por esses dispositivos, suas normativas, suas esferas de controle e seu efeito sobre as coisas e os $\operatorname{corpos}^{32}$.

No original: "Representations of space have at times combined ideology and knowledge within a (social-spatial) practice. Classical perspective is the perfect ilustrationof this. The space of today's planners, whose system of localization assigns an exact spot to each activity, is another case in point”. Este é o tema que o crítico de arte e ensaísta Jonathan Crary examina no livro Técnicas do Observador - Visão e Modernidade no Século XIX (1990), no qual investiga como aparatos técnicos, desde o século XIX, moldaram o modo de ver moderno e contemporâneo, refletindo numa normatização da visão como processo indissociável de uma operação de poder social. 


\section{A leitura do espaço cotidiano}

Lukasz Stanek ${ }^{33}$, arquiteto que tem se dedicado ao entendimento de como a aplicação dos conceitos de Henri Lefebvre contribui para a pesquisa em arquitetura, e de que forma suas reflexões se tornaram centrais no presente debate arquitetônico sobre o espaço, destaca que o cotidiano foi o que inicialmente seduziu parte da crítica, uma vez que fornecia novos instrumentos de análise para uma arquitetura "mais atenta aos ambientes cotidianos vivenciados por pessoas" (STANEK, 2012, online), assim como possibilitava novas abordagens em relação às neovanguardas que, desde os anos 1960, realizavam experimentos que desafiavam os limites entre arte e vida "como gestos heroicos que emulavam as vanguardas dos anos 1920” (STANEK, 2012, online).

É oportuno, nesse sentido, localizar que não é casual o cruzamento de experimentos engendrados pelas artes e as vanguardas dos anos 1920 nesse debate. Lefebvre manteve uma relação próxima de amizade com artistas dadaístas e surrealistas, em especial com Tristan Tzara e André Breton ${ }^{34}$, fato que teria sido determinante para sua elaboração crítica sobre os efeitos alienantes da vida moderna, assim como de possibilidades emancipatórias que poderiam ser alcançadas pelo "poder animador do espetáculo, da poesia e das práticas artísticas que se tornariam cruciais para informar sua atitude e participação ativa nos movimentos revolucionários dos anos 60” (HARVEY,1992, p. 426). É também conhecida a proximidade de Lefebvre com Guy Debord ${ }^{35}$, figura central

33 Lukasz Stanek é arquiteto e professor de história da arquitetura na Universidade de Manchester, no Reino Unido, tendo já lecionado na ETH, em Zurique, e na Harvard Graduate School of Design.

A esse respeito, existe uma menção de Lefebvre, em A produção do espaço, à importância do surrealismo para "a decodificação de um espaço interior e que ilumina a natureza transitória deste espaço subjetivo para a esfera material do corpo no mundo externo, consequentemente da vida social. Portanto o surrealismo tem uma importância teórica que não foi originalmente reconhecida. O esforço surrealista em encontrar uma unidade desse tipo iniciou uma pesquisa que mais tarde se perdeu" (LEFEBVRE, 1991, p. 18, tradução minha). de sociologia do cotidiano coordenada por Lefebvre, em Nanterre, 
para a Internacional Situacionista (I.S), e cujos escritos foram fundamentais para os desdobramentos do movimento de Maio de 1968, na França.

As críticas de Lefebvre às premissas operativas do urbanismo de Estado francês - que desprezava a experiência de vida dos futuros moradores, corroborando a alienação do cotidiano - e o Urbanismo Unitário (U.U.) situacionista possuem inúmeros pontos de contato. As elaborações de Lefebvre sobre o impacto da privatização da vida nas cidades, e a consequente transição do status da cidade como obra para cidade como espetáculo, o levam a valorizar o imprevisto e a surpresa como disparadores de uma experiência vivenciada capaz de oferecer resistência ao domínio da cultura de massa.

Em seus escritos, estão presentes a ideia de apropriação como oposição às necessidades criadas pelo consumo, que contamina a experiência de vida nas cidades transformando-a em alienação, assim como o conceito de jogo como forma de combatê-la. Em um livro editado a partir de uma pesquisa sobre cidades balneário na Espanha, esquecida nos arquivos de um de seus colaboradores ${ }^{36}$, é possível encontrar uma reflexão do autor sobre o gozo ${ }^{37}$ como uma experiência do corpo relacionada à importância dos espaços de lazer, sem fins produtivos e voltado para uma prática poética ${ }^{38}$. Da observação do turismo de massa, um modo de consumo voraz do espaço, Lefebvre infere que "o uso, mesmo que caricatural,

para o qual desenvolveu análises sobre o impacto da cultura e do consumo de massa na vida cotidiana (STANEK, 2011, p. 18 e 50). Foi também Lefebrvre quem o colocou em contato com Raoul Vaneigem (STANEK, 2011, p. 18 e 50), com quem viria a formar a I.S.

Em 1973, a convite do arquiteto Mario Gavira, ex-aluno, amigo e um colaborador próximo, Lefebvre responde a uma encomenda para integrar um estudo comissionado sobre cidades turísticas na Espanha. Gavíria decidiu, por fim, não incluir o texto de Lefebvre na publicação final por considerá-lo muito abstrato. A arquitetura, embora implicada desde o título, Toward an architecture of Enjoyment, ou Por uma arquitetura do gozo, faz clara provocação à Por uma arquitetura (1923), de Le Corbusier. A arquitetura é central às elaborações do autor que, ao longo dos capítulos do livro, entrecruza filosofia, antropologia, história, psicologia, semiologia e economia demonstrando sua concepção multidisciplinar do espaço e empregando uma abordagem que buscava superar as divisões entre domínios de especialização científica. A tradução do termo francês jouissance para enjoyment no inglês, e finalmente para "gozo" em português, advém da relação que o autor estabelece com sua elaboração pela psicanálise a partir de Lacan.

38 “O que eu chamo de 'prática poética’ é intensificação da experiência vivida associando-a ao mundo percebido, acelerando as interações e interferências do corpo e de seu entorno” (LEFEBVRE, 2014, p. 35). 
de trabalhos e espaços deve prover o gozo" (LEFEBVRE, 2017, p. 20, tradução minha ${ }^{39}$ ), e com isso provoca a arquitetura a recuperar sua capacidade de criar espaços que possam ser apropriados pelo uso.

Para Stanek, autor de Henri Lefevbre on Space. Architecture, Urban Research, and the production of theory (2011) e editor de Toward na Architecture of Enjoyment (2014) duas publicações que evidenciam a relação imbricada entre a pesquisa, a crítica e o projeto de Lefebvre com o pensamento e a produção da arquitetura e do urbanismo no segundo quarto do século XX -, é somente após a tradução de The Production of Space (1991) para o inglês que a crítica arquitetônica angloamericana se dá conta do potencial que a tríade dialética do espaço era capaz de apresentar. Ainda segundo Stanek, é a circulação deste livro que desencadeia um retorno a outros textos de Lefebvre ${ }^{40}$, dado o ânimo sobre sua interpretação da vida cotidiana como um contraponto ao então corrente debate estruturalista, acusado de hermetismo e desconexão com o mundo real e a prática.

Não que essa visada não tivesse sido explorada pelo campo arquitetônico. Afinal, são questões que já estavam presentes nas discussões do Team $10^{41}$ - desde que decretaram o fim dos Congressos Internacionais de Arquitetura Moderna

39

40

"The consumption, or, rather, use, evencaricatural, of works and spaces must provide enjoyment".

Cabe ressaltar que, no Brasil, houve uma intensa leitura e interpretação dos textos de Lefebvre iniciada nos departamentos de Sociologia e de Geografia da Universidade de São Paulo, posteriormente difundida para outros campos e faculdades pelo país. Stanek se refere ao contexto angloamericano quando, entre outras coletâneas, excertos de textos de Lefebvre são publicados em livros como Architecture Theory since 1968 (1998), no qual K. Michael Hays o insere no debate sobre a produção da arquitetura e seu contexto social, ou Rethinking Architecture: A Reader in Cultural Theory (1997), organizado por Neil Leach com a intenção configurar um campo de debate expandido da arquitetura no campo cultural.

Os Congressos Internacionais de Arquitetura Moderna no pós-guerra - o CIAM VI, em 1947, e o CIAM VII, em 1949, ainda debatiam o emprego da Carta de Atenas (1933) como direção para a reconstrução e para enfrentamento da crise habitacional. O questionamento à essa diretriz se intensifica nas edições VIII e IX, com a formação do Team 10 - grupo formado com maior regularidade e participação dos arquitetos Jaap Bakema, Georges Candilis, Aldo van Eyck, Giancarlo De Carlo, Alison e Peter Smithson e Shadrach Woods - que leva à dissolução do colóquio na sua décima edição, em 1956. O grupo tentava equacionar nexos entre arquitetura e cidade, e entre a cidade e seus habitantes, por meio da substituição da hierarquia funcional por uma relação pautada pelas associações humanas - premissa para estipular relações de escala, e construir identidade e significado para pessoas reais. 
(CIAMs), em 1956 -, mas foram diluídas no intenso e plural debate teórico desencadeado pela profusão de correntes de pensamento do chamado período pós-moderno. A cidade e o cotidiano são questões presentes nos dois livros tidos como importantes marcos teóricos ${ }^{42}$ da transição para a pósmodernidade: A arquitetura da cidade (1966), de Aldo Rossi, e Complexidade e contradição em arquitetura (1966), de Robert Venturi.

Rossi voltou-se para a leitura da cidade europeia na qualidade de artefato, para nela reconhecer o genius loci - ou a singularidade da experiência espacial de um lugar como decorrência do trabalho humano, impregnado pelos valores culturais expressos nas diferentes tipologias, valores simbólicos que haviam sido desqualificados pela tábula rasa do período moderno.

Venturi também procura desvelar os significados dos edifícios por meio de uma leitura da história da arquitetura sem descartar a arquitetura moderna -, para nela reconhecer as ambiguidades e tensões que derivam de características interiores aos edifícios, assim como de seu contexto, resultando no "todo difícil”, ou seja, uma arquitetura que realiza a acomodação das partes, e assume contradições e dualidades em sua totalidade.

Em ambos, há uma tentativa de superar a tensão entre o viés racional, representado pela função e a tecnologia empregados na produção arquitetônica, e o impacto da realidade, correspondendo à história e à cultura de um lugar. Mas, com Venturi, esse desejo se manifesta também pelo reconhecimento da paisagem cotidiana e vulgar, como declara no último capítulo de Complexidade e contradição em arquitetura(2004), a partir da leitura de um livro de Peter

Outro marco simbólico, segundo o teórico Charles Jencks, foi a demolição do conjunto habitacional Pruitt-Igoe. Em suas palavras, "o principal motivo da arquitetura pós-moderna é, obviamente, o fracasso social da arquitetura moderna, tendo sua 'morte' mítica anunciada por críticos como eu. Em 1968, um bloco de moradias inglês, Ronan Point, sofreu o que foi chamado de 'colapso cumulativo' quando seus pisos cederam após uma explosão. Em 1972, muitos blocos de moradias foram destruídos intencionalmente em Pruitt-Igoe, em St. Louis. Em meados dos anos setenta, essas explosões estavam se tornando um método bastante frequente de lidar com as falhas dos métodos modernistas de construção: fabricação barata, falta de espaço pessoal "defensável” e o conjunto habitacional alienante. A "morte" da arquitetura moderna e sua ideologia do progresso, oferecendo soluções técnicas para problemas sociais, foi vista por todos de maneira vívida" (JENCKS, 1987, p. 34). 
Blake $^{43}$ :

Em God's Own Junkyard (1964), ilustrações da Times Square e pequenas cidades à margem de rodovias são comparadas com ilustrações de aldeias e campos bucólicos da Nova Inglaterra. Mas as imagens nesse livro que se presume serem ruins são frequentemente boas. As justaposições aparentemente caóticas de elementos vulgares expressam uma intrigante espécie de vitalidade e validade, e produzem também uma inesperada abordagem da unidade. (VENTURI, 2004 p. 146).

É justamente o interesse pela vitalidade e a vulgaridade que motiva Denise Scott Brown e Robert Venturi, junto com Steve Izenour, a se deslocarem com um grupo de estudantes da faculdade de arquitetura de Yale para analisarem a "strip", o corredor comercial de Las Vegas, em 1968. Essa expedição deu origem ao livro Aprendendo com Las Vegas (1972) <imagem C1.1 p.70>, um verdadeiro ponto de inflexão no modo como eram pensados e produzidos os livros de arquitetura.

O ânimo inicial despertado pelo experimento recaia principalmente sobre sua originalidade e frescor, ao empregar meios de representação inovadores para além do tradicional repertório da arquitetura - pelo menos o repertório de até então -, para, por meio de gráficos, tabelas, fotografias, filmes e textos, conduzirem o leitor por descobertas das quais inferem elaborações sobre o potencial simbólico e comunicativo dos edifícios do corredor comercial, tão comuns às cidades norte-americanas. Há uma aposta, portanto, de que o extraordinário está não somente contido na cidade existente, como está presente em estado de latência, à espera de ser desvendado.

O procedimento empregado pelo grupo de arquitetos e seus estudantes remete às leituras fotográficas da cidade de Los Angeles feitas pelo artista Edward Ruscha, particularmente no coincidente registro do fenômeno urbano da "strip" ${ }^{44}$, em Every Building on Sunset Strip (1966)

Peter Blake, um arquiteto alemão naturalizado norte-americano, foi, entre 1948 e 1950, curador de arquitetura e design do MoMA, em Nova Iorque, além de editor chefe da revista Architectural Forum (1892-1974), de 1965 a 1972, onde consolidou-se como crítico de arquitetura.

44 Ed Ruscha é mencionado nos agradecimentos do prefácio da primeira edição de Aprendendo com Las Vegas, e no catálogo de uma exposição 
<imagem C1.2 p.71 >. São muitos os paralelos, dentre eles, o fascínio pelos signos da cultura pop norte americana, como os estacionamentos, a cidade espraiada, o corredor comercial, os grandes letreiros como elementos comunicativos que dominam a paisagem, a escala para ser apreendida do ponto de vista do motorista e, principalmente, as especulações sobre a função simbólica dessa arquitetura, resumida nos opostos: o "pato" - tipo de edifício que desvirtua questões funcionais para atingir resultados expressivos até se tornar ornamento per se -, e o "galpão decorado", edifício genérico que explicita sua matriz funcional cujas fachadas são posteriormente decoradas.

Após um hiato, o livro é retomado no início dos anos 2000. Se por um lado o distanciamento histórico favoreceu uma leitura crítica sobre o modo como Aprendendo com Las Vegas renegou qualquer aspecto simbólico que a arquitetura moderna pudesse conter, dada sua postura populista demasiadamente engajada com o real, por outro lado sua perspectiva antropológica, que confere importância ao existente, inaugura uma espécie de método para a análise e interpretação de "cidades reais". Uma demonstração de que essa investigação especulativa rende evidências e agencia descobertas. Aproximado como par análogo de Nova Iorque delirante (1978), de Rem Koolhaas, ambos inauguram uma espécie de gênero literário: o manifesto arquitetônico paradoxal $^{45}$.

Apresentado como um manifesto retroativo, Nova Iorque delirante declara que, se a fragilidade dos manifestos é sua falta de evidências, a cidade de Nova Iorque era a grande evidência sem um manifesto, ou o ápice da cidade moderna

sobre fotos originais remanescentes nos arquivos de Venturi e Scott Brown. Uma conversa publicada nesse catálogo entre Rem Koolhaas, o artista Peter Fischili e o curador Hans Urich Obrist, este último revela que durante uma entrevista com Ruscha, ele mencionou ter sido visitado pelo grupo de estudantes e seus professores a caminho de Las Vegas (STADLER; STIERLI, 2009, p.162) .

Paradoxal, na medida em que o próprio movimento moderno já deixara transparecer as limitações de um manifesto arquitetônico, em razão da facilidade com que seus argumentos se desintegram. Os manifestos, segundo Enrique Walker (2018, p.87,tradução minha), "provaram estar curiosamente em desacordo com a prática da arquitetura, pois geralmente são elaborados antes e independentemente das circunstâncias específicas de um projeto e, por sua vez, frequentemente se choca com eles. Nas ocasiões em que um manifesto e um projeto não se chocam, o manifesto finalmente condena o projeto a ser meramente uma ilustração”. 
e dos efeitos da pressão do mercado e da cultura de massa sobre espaço urbano, que possibilitou do advento do elevador ao arranha-céu, da fabricação do território reticular de Manhattan ao lazer delirante de Coney Island.

O livro acaba sendo o trabalho de estreia de Koolhaas, conferindo-lhe notoriedade mais pela elaboração teórica do que por sua atividade prática. Um indício de seu bemsucedido modo de operar que estabelece correspondências entre pesquisa, elaboração teórica e prática, ao mesmo tempo em que requisita esse trânsito como condição ${ }^{46}$ para uma reconfiguração disciplinar em contato mais próximo com o mundo. Essa interpretação é a provável razão pela qual Koolhaas, a frente do OMA (Office for Metropolitan Architecture), tenha se destacado na virada do milênio ao tomar a dianteira no enfrentamento das condições que se enunciavam nas metrópoles globais.

Assim, mobilizando conhecimentos específicos da formação arquitetônica, aproximados de outros campos disciplinares, Aprendendo com Las Vegas e Nova Iorque delirante elaboram, de modo semelhante, uma estratégia que vem sendo replicada desde então, e com grande intensidade nas últimas duas décadas, desencadeando uma série de iniciativas baseadas na aproximação e análise das condições reais como laboratório da prática arquitetônica.

Esse é o caso da série de investigações coordenadas por Koolhaas, na Harvard Graduate School of Design ${ }^{47}$, e que são rebatidas diretamente no modo como o OMA desdobra de sua frente projetual e prática um espelhamento, o AMO, braço de pesquisa e design que opera paralelamente, apoiando os projetos desenvolvidos pelo OMA. Também

Em uma conversa com Peter Eisenman, numa conferência na Architecture Association (A.A), em Londres, onde estudou, Koolhaas comenta: "Não entendo como uma profissão pode se realizar com essa combinação de intervenção, mudança, execução e ação como base para prática, deixando a abstinência, a observação e a reflexão à margem. Recentemente, assistimos a uma tal guinada nos tipos de relação dentro da arquitetura que, para nós, talvez tenha se tornado embaraçoso" (EISENMAN, 2013, p. 27).

47 Esse projeto, denominado Project on the City, procurou registrar e interpretar as mudanças da condição urbana em todo o planeta, explorando cidades como Roma, Lagos, Moscou e Pequim, resultando em três publicações, todas lançadas em 2001: Mutations, Great Leap Forward, especificamente sobre o delta do rio das Pérolas, na China, e The Harvard Guide to Shopping, um estudo sobre o papel do varejo e do consumo na sociedade contemporânea. 
servem de exemplo os dois livros do Atelier Bow-Wow sobre a cidade de Tókio, Made in Tokio (2001) e Pet Architecture (2002), nos quais documentam e analisam soluções informais para elaborá-las posteriormente como soluções em seus projetos.

Mas esse movimento de implicação dos arquitetos com o espaço real, reverberando diretamente sobre a disciplina, não deve ser confundindo com mera interpretação de formas e significados dos edifícios e seus modos de produção. Tal adesão ao real pode ser compreendida também por um viés de interpretação do efeito do corpo e dos usos sobre esses espaços, ou por práticas cotidianas como tratadas por Michel De Certeau em A invenção do cotidiano (1980) ${ }^{48^{\prime}}$ - outro autor que passa a ser lido de modo recorrente pela arquitetura a partir dos anos 1990.

Essas práticas cotidianas - conversar, ler, circular, fazer compras, cozinhar, habitar, entre outras - são, para De Certeau, táticas desviacionistas da maior importância, por estabelecerem uma contraposição contínua às estratégias de controle do espaço pelo planejamento tecnocrático, o qual, segundo modelos abstratos, instaura as relações de poder que o sustenta. O que distingue os polos dessa equação são os “tipos de operação" sobre espaços: enquanto a estratégia impõe uma configuração, as táticas manipulam, apropriam e provocam alterações pelo uso do espaço, num contínuo movimento que se dá na escala do corpo, e por uma prática anônima, que nesse sentido apresenta uma perspectiva otimista sobre a potência transformadora da apropriação como fator de resistência ao poder hegemônico.

Por esse princípio, seria possível inferir que caberia à arquitetura o lugar do planejamento estratégico, mas a reconfiguração dos limites disciplinares na medida em que o debate arquitetônico abraça o capital cultural pós-moderno, a partir dos anos 1960, provoca uma revisão e expansão também das práticas ${ }^{49}$ comumente atribuídas à profissão,

Fevereiro de 1980 é data da primeira publicação do estudo coordenado por Michel De Certeau na França. A pesquisa que dá origem ao livro foi desenvolvida entre 1974 e 1978.

Peggy Deamer, arquiteta e professora em Yale, chama a atenção no texto "Practicing Practice" (2011), que a constituição de um novo modelo para a prática arquitetônica está totalmente em jogo na atualidade. A redundância do título explicita que praticar a "prática seria o ato de ensaiar um comportamento, um método de aprender, de adquirir 
uma vez que processos e questões conceituais passam a ser valorizados, tendo em vista resultados sociais e políticos num contexto mais amplo que o caráter espacial da disciplina pode agenciar; nas palavras da arquiteta Peggy Deamer (2011, p. 161, tradução $\operatorname{minha}^{50}$ ):

"Para aqueles treinados em atribuir valor singular à estética do objeto, é um ajuste atribuir o pensamento criativo à eficácia do processo".

Com isso, o termo prática espacial crítica, apropriado da noção tripartida de espaço postulada por Lefebvre, vem desde então ganhando destaque por sua capacidade de compreender uma diversidade de mecanismos que afetam e transformam as condições espaciais em que vivemos.

Uma prática espacial crítica poderia abarcar a expansão das atividades normalmente atribuídas aos arquitetos, compreendendo tanto um campo discursivo - curadorias, estruturas institucionais e pesquisas -, como ações e intervenções propositivas que consideram e mobilizam as realidades sociais em que se inserem, notabilizando a importância dos processos empregados e, consequentemente, relativizando a importância devotada ao edifício.

Nesse sentido, a arquitetura seria revigorada pelo contato com disciplinas correlatas ao expandir-se e ocupar suas bordas, particularmente no caso daquelas que a aproximam da arte, possibilitando repensar seu lugar de atuação em meio à polaridade contemporânea relegada ao arquiteto e urbanista, que ora se depara com a grande obra singular, ora com subprodutos que se alastram à revelia de sua interferência.

experiência de empreender uma estratégia para a sua realização" diante de uma conjuntura de hegemonia capitalista. Desse modo abrindo-se para diferentes habilidades como "novos jogadores no jogo do gerenciamento, os arquitetos estão livres para avançar diretamente rumo a um ideal imaginado utópico" (DEAMER, 2011, p. 161-203).

50 "For those trained in assigning singular value to the aesthetics of the object, it is an adjustment to assign creative thought the efficacy of the process". 


\section{O espaço entre arte e arquitetura: do site-specific à arte útil}

Como consequência da leitura e absorção das noções de espaço lefebvrianas entre os arquitetos, um conjunto de publicações, a partir dos anos 2000, emprega-as para analisar e validar práticas experimentais que expandem os limites da arquitetura, assim como para reconhecer o engajamento das artes em processos semelhantes, voltados para a esfera pública, o comum, as relações e os usos por meio de incursões disruptivas na organização espacial.

Este é o caso de Warped Spaces. Architecture and Anxiety in Modern Culture (2001), de Anthony Vidler, que parte do reconhecimento de que o espaço é uma condição central de aproximação da produção artística e arquitetônica. Apoiado na tríade lefebvriana, o autor opta por "conscientemente limitar-se a uma análise do espaço de representação” (VIDLER, 2000, p.13, tradução minha) ${ }^{51}$. Além dessa leitura e recorte, Vidler demanda uma quarta camada que, segundo ele, teria sido ignorada por Lefebvre, e que seria voltada à elaboração do espaço como projeção do sujeito, suas ansiedades e condições psicológicas, “iluminando as relações que incessantemente alternam da construção espacial para a construção de identidade” (VIDLER, 2000, p.13, tradução minha $)^{52}$.

Dessa maneira, tanto o "espaço de representação" quanto o "espaço psicológico" elaborado por Vidler são compreendidos como um campo de aproximação entre a produção de artistas e arquitetos a partir de especulações que ora convergem, ora se chocam, num campo crítico e prático comum de distorção espacial.

No original: "In this regard, my own criticism is consciously limited to that of representational space produced by architects, artists and critics, as it marked the one spatial practice left unanalized by Lefebvre: that of the post-psychoanalytical imaginary, as it seeks to trace out the sites of anxiety and disturbance in the modern city". construction to identity". 
Vidler percorre uma série de exemplos, como as investigações documentais de Martha Roesler sobre o deslocamento humano e os fluxos massificados globalmente <imagem C1.3 p.72>; as instalações de Vito Acconci, que assumem a forma de estruturas arquitetônicas e mobiliários que transitam entre domesticidade e espaço público produzindo um efeito desorientador; a fundição em concreto de espaços domésticos à beira da demolição para uma renovação urbana, por Rachel Whiteread; ou a presentificação espacial de memórias reprimidas, de Mike Kelley <imagem C1.4, p.73>. Do mesmo modo são abordados projetos do grupo de arquitetos austríacos Coop Himmeb(l)au < imagem C1.5, p.74>, que descentralizam as noções clássicas baseadas na perspectiva e nas proporções harmônicas para contorcer estruturas como ossaturas, ou utilizar a tecnologia como extensão do corpo; as bolhas parametrizadas de Greg Lynn, ou os projetos de Daniel Libeskind, como o Museu Judaico de Berlim, edifício reconhecido por produzir efeitos desconcertantes no público, onde o espaço vazio e sem conteúdo é literalmente a obra a ser experimentada.

Pode-se notar, portanto, que o espaço distorcido e psicológico da análise de Vidler, ao menos na última década do século XX, descrevia uma arquitetura de caráter sobretudo fenomenológico. Suas leituras de casos que entrecruzam crítica de arte e teoria arquitetônica, partem de um campo de ambiguidades entre as categorias escultura e arquitetura, e o conduzem a identificar uma reconfiguração da experiência espacial provocada inicialmente pela produção tridimensional. Uma investigação que resulta na sua transposição proposta pelo autor do termo 'campo ampliado' para arquitetura, apoiado pelo seminal texto Sculputure in the Expanded Field (1979), da crítica e historiadora da arte Rosalind Krauss.

Como um caso de confirmação de que certos parâmetros se tornam mais claros primeiramente na arte, para serem posteriormente absorvidos pelo campo arquitetônico, Vidler declara que não seria exagero assumir que o campo ampliado arquitetônico “deve em muito à ampliação anterior do campo da escultura” (VIDLER, 2008, p.251).

O texto original de Krauss, publicado na October $n^{\circ} 8-$ revista acadêmica que ajudou a criar e consolidar -, tentava abarcar as múltiplas formas que a escultura vinha assumindo, 
no final dos anos 1960, e ao longo dos $1970^{53}$, no cenário norte-americano. Neste período, a land-art se lançava rumo à paisagem das grandes extensões territoriais, abandonando a galeria, enquanto o minimalismo incluía o espaço da galeria na experiência da obra ao retomar o ready-made duchampiano na produção de peças, valendo-se para isso de materiais industrializados recombinados em série, esgotando qualquer significado formal pela sua disposição como pura exterioridade e literalidade.

Em comum, esses procedimentos contribuíam para uma reconfiguração da experiência, agora expandida para o entorno, numa radical descentralização da obra. Tal reconfiguração, desde uma perspectiva histórica, representava uma perda gradativa das especificidades da escultura como meio - processo iniciado por Rodin nos primórdios da escultura moderna -, e sua extensão para uma fruição do espaço por meio da total implicação sensorial do corpo, embaralhando os limites entre obra e entorno, assim como as fronteiras entre o interior das galerias e o mundo.

É essa condição deflagrada pela produção tridimensional que Vidler retoma para estabelecer um caminho inverso de aproximação e convergência, desta vez percorrido pela arquitetura. Apoiando-se no emblemático caso de Titled Arc (1981-1989) - escultura de Richard Serra que dá origem ao termo site-specific, após a polêmica em torno de sua remoção da Federal Plaza, em Nova Iorque -, o autor realça que a instalação de obras no espaço público dilata ainda mais as ambiguidades entre as categorias escultura e arquitetura, uma vez que as reconfigurações espaciais resultantes instigam outro tipo de aproximação com o trabalho, implicando uma combinação de "uso vivencial, estético e funcional” (VIDLER,

Naquele período, segundo Krauss, era mais fácil compreender a escultura por suas características negativas, ou seja, aquilo que não é o edifício, ou o que está na paisagem sem ser a paisagem. Para reconfigurar um sistema de valores para análise dessas obras, Krauss incorpora os termos paisagem e arquitetura como definidores da escultura, e utiliza um diagrama no qual, pela oposição de duas negativas derivam novos termos binários e consequentemente quaternários. Assim, além da escultura, essa expansão resulta em três manifestações de um campo ampliado: o "sítio-construção", o "sítio-demarcado" e a "estrutura axiomática”. O gráfico pode ser visualizado na página 37 do artigo de Krauss, ou em uma versão traduzida por mim em minha dissertação de mestrado Intersecções entre arte e arquitetura. O caso dos pavilhões(2013), na página 21, na qual me baseei na tradução realizada por Elizabeth Carbone Baer publicada no primeiro número da Revista Gávea. 
2005, p.246).

O lugar e o uso, portanto, atacam princípios

fundamentais para a distinção ortodoxa das esferas da prática da arte e da arquitetura, oferecendo uma leitura que extrapola fundamentos disciplinares baseados nas oposições entre experimentação formal puramente estética como território da arte e determinação de usos para a construção de espaços funcionais como atribuição da arquitetura. Não é à toa que, por meio de novos conceitos de programa, Vidler enxergue um caminho para o campo ampliado arquitetônico ${ }^{54}$ capaz de confrontar condições políticas e socioeconômicas contemporâneas no novo contexto global.

A arquitetura e a cidade configuram, assim, um importante marco para a dissolução definitiva da escultura como categoria, na medida em que artistas passam a explorar tanto um vocabulário tectônico e seus efeitos fenomenológicos quanto as potencialidades de acesso a um espaço social e seus modos de produção imbricados na vida cotidiana, implicando também camadas experienciais, sociais e históricas presentes no espaço.

Ainda que Tilted Arc inaugure o debate acerca da especificidade e represente também um importante deslocamento discursivo a propósito de intervenções sitespecific no espaço público ${ }^{55}$ - a partir da fundamentação de Serra sobre sua remoção representar a destruição do trabalho, jamais uma adaptação a outro local - os desdobramentos desse entrelaçamento entre questões discursivas e práticas se complexifica a partir de então.

Em vista disso, fica evidenciada a inextricável relação

54 Dentre dualismos atávicos e estruturantes da disciplina arquitetônica, Vidler cita forma e função, historicidade e abstração, utopia e realidade, e estrutura e vedação como condições a serem superadas para que novos princípios estruturadores pudessem emergir. Assim, a partir da recombinação entre arquitetura e paisagem, arquitetura e biologia, e arquitetura e programa, seria possível encontrar três novas possibilidades de configuração para um campo ampliado arquitetônico.

55 Serra tem clara intenção de sublinhar as camadas subjacentes ao espaço público, direcionando uma crítica à arquitetura como manifestação de ideologias e poder, que ele expõe tornando pública a correspondência trocada, como o programa Art-in-Architecture, do General Services Administration (GSA)- órgão público norteamericano que supervisiona o comissionamento de obras de arte para novos edifícios federais financiadas por uma tarifa que corresponde a $1 \%$ do valor de construção dos edifícios - responsável pela encomenda e posterior solicitação da remoção da obra. 
entre o trabalho e o lugar como uma afirmação de seu procedimento crítico. Essa é uma questão central no trabalho de Serra, marcado pela presença física da obra - com suas características de escala, matéria, textura, implantação - como indutora de uma experiência que proporciona uma redefinição do espaço no qual se insere.

Trata-se de um procedimento que ecoa o ponto de vista de Michael Heizer que, em conversa com Dennis Oppenheim e Robert Smithson ${ }^{56}$, afirma que "o trabalho não é posto em um lugar, ele é esse lugar” (HEIZER, 2006, p.275).

Essa redefinição do trabalho como o lugar, e a ampla assimilação do termo site-specific por artistas, arquitetos e instituições nas últimas décadas do século XX, passa, sobretudo, por um deslocamento que se refere a uma relação crítica e discursiva estabelecida a partir de um dado lugar. Ora é o espaço da galeria que é afrontado em sua condição de "cubo branco" 57 , sustentado por um suposto código de neutralidade moderno cuja lógica passa a ser física e conceitualmente abordada por um artista como Michael Asher <imagem C1.6 p.75>, ora é a cidade que é apropriada como campo de experimentação.

Assim, o lugar passa a ser um disparador de situações que são criadas de forma a implicar a esfera pública e as relações cotidianas em um contexto político-social expandido, a exemplo do restaurante Food (1971) <imagem C1.7 p.76>, que Gordon Matta-Clark abriu e administrou junto com as artistas Carol Goodden e Tina Girouard, ou o espaço para exposições criado e gerido pelo Group Material <imagem C1.8 p.77>, no início dos anos 1980, ambos em Nova Iorque.

Esses dois exemplos são significativos para a compreensão do grau de fragmentação da arte a partir

O trecho é a epígrafe do texto "Discussões com Heizer, Oppenheim, Smithson", publicado originalmente em 1970 e considerado emblemático para o debate sobre a landart e os desdobramentos da escultura nesse período.

"Cubo branco" é uma convenção consolidada em referência ao recinto supostamente estável e apartado do mundo exterior, que cria o contexto de neutralidade e primazia do olhar sobre a obra de arte - ou seja, o templo moderno que estabeleceu as condições de isolamento e controle por trás da estética modernista. Em No interior do cubo branco (1976), o artista Brian O’Doherty passa em revista o termo e as subversões desse espaço como matéria-prima, desde o modo como Marcel Duchamp expõe, pela primeira vez, os efeitos do contexto sobre a arte, alterando todo o espaço da galeria para a Exposição Internacional do Surrealismo, em 1938, em Nova Iorque. 
da dissolução da especificidade do meio e da adesão a práticas orientadas ao lugar como não dependentes de uma materialidade. Tendo o minimalismo como ponto inaugural, a retomada do legado das vanguardas do século XX manifestase, segundo Lucy Lippard ${ }^{58}$ (1973, p. IX), em duas vertentes principais: “a arte como ideia, e a arte como ação”.

Informados pelo contexto, trabalhos orientados ao lugar mobilizam ideia e ação como processos direcionados à crítica institucional, mas também como alternativa crítica ao mercado de arte, até então dependente da circulação de objetos. Procedimento que ocasiona desdobramentos e acaba por reconfigurar o papel do artista também como um “provedor de serviços” (KWON, 2004, p. 4, tradução minha ${ }^{59}$ ).

Julie Ault, artista que integrou o Group Material, comenta, em um texto escrito em conjunto com o curador Martin Beck, como nesse período uma série de condições possibilitou a formação de uma coalizão de artistas, a Art Worker Coalition (AWC). Segundo Ault e Beck, programas de financiamento público, imóveis baratos, diversidade social e uma agenda política comum aproximaram artistas que desafiaram o sistema estabelecido de produção e fluxo de uma arte mercantilizada e desconectada de questões políticas.

Tais condições incentivaram a reinserção de pautas e discussões numa esfera pública abrangente, tanto em um sistema de novas galerias alternativas quanto em instituições consolidadas que passam a ser pressionadas por práticas críticas. Com isso, lugares estabelecidos do sistema de arte também foram contorcidos por propostas que desafiavam os papeis exercidos por artistas e curadores, afetavam as dinâmicas de exposição e obra, ou distendiam a relação entre espectador e obra.

É nesse contexto que se pôde observar uma aparente inversão de papéis, quando arquitetos passaram a considerar e comercializar itens processuais como elementos de

Importante ressaltar o trabalho da crítica e curadora Lucy Lippard como pioneiro na documentação e estruturação de um arquivo de eventos, em ordem cronológica, a partir do qual argumenta a tendência de desmaterialização da obra arte no contexto norte-americano, em Six Years: The dematerialization of the art object from 1966 to 1972 (1973). Segundo a autora, tendo o minimalismo como precedente, e Marcel Duchamp como referência histórica para a prática artística "emergia em duas direções: a arte como ideia, e a arte como ação” (LYPARD, 1973, p. IX).

"the reconfiguration on the role of the artist (now a culturalartistic service provider, rahter than aproducer of objects)". 
especulação teórica e crítica - principalmente nas primeiras bienais e galerias voltadas a publicizar a produção arquitetônica $^{60}$ - e a valorizar gestos escultóricos para produção de edifícios singulares ${ }^{61}$. Ao mesmo tempo, artistas desenvolviam projetos de grande escala, com complexas etapas de planejamento e produção, reunindo equipes multidisciplinares - para o enfrentamento técnico e o compartilhamento de responsabilidades -, ou atuavam próximos às comunidades locais recorrendo a processos participativos para decisões de impacto social na esfera pública.

Esse modus operandi, hoje incorporado pela produção cultural dominante e absorvido pelas forças de mercado, vem, desde então, sendo estimulado por bienais, festivais e instituições nas quais os artistas ressurgem como provedores de serviços artísticos para proporcionarem uma experiência única e sem reprodução. Nesse sentido, a crítica de arte Miwon Kwon coloca que, no decorrer desse processo:

Adotou-se no processo um etos funcionalista que priorizou o valor de uso da arte pública em detrimento de seu valor estético, ou mensurou seu valor estético em termos de valor de uso. Essa mudança se baseou no desejo de muitos artistas e agências públicas de arte de reconciliar a divisão entre arte e utilidade - para tornar a arte pública mais acessível, responsável e relevante para o público. (KWON, 2004, p. 69).

Um exemplo patente que favorece a leitura do modo como

Ver conferência Revisitando o Museu do Capitalismo Tardio (2011), de Beatriz Colomina, no Now Museum, sobre como a intensificação desse fenômeno, nas décadas de 1970 e 1980, aproximou uma geração de artistas e arquitetos em Nova Iorque e deixou como legado para a cidade espaços que se consolidaram ou que foram absorvidos por instituições consolidadas como o PS1e o Storefront for Art and Architecture. Disponível em: http://www.forumpermanente.org/ event_pres/simp_sem/conferencia-internacional-the-now-museum/ videos/o-museu-do-agora-beatriz-colomina. Acesso 19 jul. 2018.

Como explorado por Guilherme Wisnik, em sua tese de doutorado Dentro do nevoeiro: Diálogos cruzados entre arte e arquitetura contemporânea (2013), na seção "Uma inusitada ponte”, a partir das propostas de Frank Gehry e Richard Serra para a exposição Collaboration: Artists and Architects (1981) promovida pela The Architectural League of New York. 
prática e absorção de trabalhos site-specific se configuram como valor cultural fundamental no circuito internacional são os desdobramentos de um projeto como Skulptur Projekte Münster, que desde 1977, a cada 10 anos, realiza um evento para instalação de obras de arte no espaço público oferecendo uma espécie de genealogia dos desdobramentos desses procedimentos. Se a primeira edição apresentava trabalhos relacionados ao lugar fenomenológico, e a segunda edição, em 1987, reuniu obras que lidavam com as narrativas localizadas, a terceira edição, realizada em 1997, foi marcada por trabalhos que se dispuseram como uma "arte a serviço"62.

Ainda que inseridas no contexto local de uma cidade pequena e sem problemas urbanos complexos, artistas projetaram intervenções de caráter temporário e permanente motivados pelo cotidiano da cidade, seus espaços de convivência, com implicação direta nos serviços públicos e nos usos dessas estruturas por seus habitantes. Per Kirkeby projetou e executou um muro e um ponto de ônibus em tijolos como infraestrutura para servir à escola local, visando criar um ambiente de espera mais acolhedor para até cinquenta pessoas, além de uma barreira sonora e visual para o pátio da escola. Tadashi Kawamata trabalhou com pacientes de uma clínica de reabilitação holandesa para construir, nas margens do lago da cidade, uma série de passarelas e uma balsa com um itinerário que conectava todos esses pontos durante o período de exposição. Jorge Pardo construiu um espaço para contemplar a paisagem enquanto se fuma um cigarro - maços estavam disponíveis numa máquina de venda. O pequeno pavilhão se projetava 50 metros lago a dentro, e foi conectado por um píer que serviu de ancoradouro para barcos.

É essa conjuntura da prática artística, na qual a esfera das relações humanas torna-se o lugar da obra de arte, e sua intensificação ao longo dos anos 1990, que leva o curador francês Nicolas Bourriaud a elaborar o termo "estética relacional” 63 como uma primeira tentativa de

Esse é o modo como o crítico de arte Walter Grasskamp se refere a um conjunto de trabalhos dessa edição do festival no texto "Art and the City" (1997) que integrava o catálogo. O Skulpture Projekt, com seu objetivo promover a produção de obras de arte no espaço público da cidade Münster, constitui uma coleção que hoje abrange mais de quarenta obras permanentes.

63 Em Estética Relacional (1998), Bourriaud localiza a prática contemporânea como resposta direta à mudança de uma economia de bens para uma economia baseada em serviços. Artistas como Rirkrit Tiravanija, 
abarcar a tendência de suspensão das fronteiras entre arte e vida ensaiadas nesse período, a partir de proposições artísticas que propiciam a interação subjetiva do público e seu contexto social como construção coletiva de sentido do trabalho. Bourriaud procura oferecer critérios para abordar essa produção e sua potência micropolítica engajada com comunidades ou criando ambientes e situações que instaurassem uma entidade social coletiva e utópica, ainda que em caráter temporário.

Portanto, o uso, ou o valor de uso, que a arte ambiciona produzir ao incidir no real e se aproximar de processos de transformação social e cultural - características normalmente relacionadas à prática arquitetônica - ganha evidência nesse debate a partir da redefinição de "pelo menos, três instituições conceituais sólidas da cultura contemporânea: o espectador, a cultura dos especialistas e a propriedade" (WRIGHT, 2016, p. 165), conforme o verbete "usos" formulado pelo escritor Stephen Wright em Para um léxico dos usos (2016).

É significativo atentar para o fato de que Wright escreve Para um léxico dos usos $^{64}$ em 2013, para o projeto da artista cubana Tania Bruguera, Associação de Arte Útil <imagem C1.9> e seus desdobramentos, o laboratório Arte Útil, no Queens Museum de Nova Iorque e o Museu de Arte Útil, no Van Abbemuseum, em Eindhoven, na Holanda. O livro é estruturado em verbetes inter-relacionados como um conjunto de ferramentas conceituais para serem utilizadas diante da “ampla virada usológica” (WRIGHT,2016, p. 11) da arte. Uma transformação que, segundo o autor, se reflete em todos os setores da sociedade como um fenômeno contemporâneo propiciado pela cultura de rede que altera os modos de

Carsten Höller, Dominique Gonzales Foerster, Philippe Parreno, Pierre Huyghe, entre outros, são tomados como paradigmas dessa mudança, que Bourriaud (2009, p. 151) define como: “conjunto de práticas artísticas que tomam como ponto de partida teórico e prático o grupo das relações humanas e seu contexto social, em vez de um espaço autônomo e privativo". Ou seja, essas manifestações procuram resgatar utopias e promover colaborações que problematizam comportamentos protocalares e desvelam relações de força, embates políticos e disputas narrativas, engajando o público com os contextos no quais se inscrevem.

O livro foi traduzido e publicado no Brasil pela Edições Aurora como parte do seminário Usos da Arte, durante $31^{\circ}$ Bienal de Arte de São Paulo. A versão original em inglês pode ser acessada gratuitamente como parte da plataforma Museu de Arte Útil disponível em: https://museumarteutil.net/wp-content/uploads/2013/12/ Toward-a-lexicon-of-usership.pdf. Acesso em: $1^{\circ}$ fev. 2020. 
produção e consumo de informação, significado e valor.

Ou seja, ao se desprender do campo autônomo de experimentação que criou para si, e do qual se tornou dependente $^{65}$, a arte passou a ensaiar novos modos de participação e uso, fazendo com que o espectador se tornasse um anacronismo, dado o sentido de distanciamento que o termo pressupõe. Assim, o espectador convertido em usuário representa uma corrosão do sistema baseado na atribuição e legitimação de valor conferidas ao especialista e no valor de mercado da obra.

Não que estas questões sejam novas, afinal Marcel Duchamp já havia problematizado a cultura dos especialistas, a autoria e autenticidade da obra com os ready-mades, atribuindo valor a objetos comuns deslocados pelo artista para o campo da arte. Da mesma forma, anos mais tarde, Duchamp explicitaria as contradições dos efeitos dos ready-mades conjecturando o que significaria o seu espelhamento, o "readymade recíproco", no qual um Rembrandt poderia ser transposto para a vida para ser utilizado como tábua de passar ${ }^{66}$. Isto é, da mesma forma como um objeto tem sua utilidade neutralizada ao ser transposto para a economia simbólica da arte, as obras de arte também seriam neutralizadas, uma vez inseridas no cotidiano produzindo valor de uso.

Pois é esse caráter funcional aliado à demasiada identificação com o real que, em grande parte, está em jogo no entrecruzamento do fazer da arte e da arquitetura desde

O verbete sobre a autonomia da arte, em Para um léxico dos usos, oferece um bom apoio a essa questão. Segundo Wright (2016, p. 25), "Quando a arte conquista um espaço para si ela o faz em nome de criar suas próprias leis. [...], tratava de tirar do alcance de controles e impedimentos impostos por autoridades religiosas e políticas, e construir uma esfera separada, em que pudesse se desenvolver mantendo sua lógica interna. [...] Esse espaço da arte autônoma, ainda que relativo, e zelosamente defendido mesmo hoje, determinou as artes da Modernidade. [...] Nunca se supôs que esse campo de autonomia fosse uma zona de conforto, mas sim um lugar onde a arte pudesse desenvolver ideias audaciosas, escandalosas, sediciosas - tarefa que se lançou a realizar".

Em uma fala no MoMA de Nova Iorque, em outubro de 1961, Duchamp manifestou sua precaução ao compreender a repercussão dos ready-mades, o que o levou a limitar sua produção a uma pequena quantidade anual, de modo a protegê-los de uma contaminação mercadológica. Nesse mesmo depoimento publicado na revista Art and Artists, em 1966, Duchamp coloca: "Interessado em expor a antinomia fundamental entre arte e os ready-mades, imaginei um ready-made recíproco: usar um Rembrandt como tábua de passar"(DUCHAMP apud WRIGHT, 2016, p.135). 
a reorganização do território da produção cultural no pósmodernismo. Um problema que já havia sido enunciado por Walter Benjamin como um desmantelamento do livre espaço de jogo, que "desloca as coisas para tão perigosamente perto da nossa cara quanto a tela de cinema crescendo gigantescamente em nossa direção” (BENJAMIM, 2009, p.55). Afirmação que é retomada por Hal Foster para colocar o problema do distanciamento crítico para o pensamento da contemporaneidade.

Entre a suspensão da proximidade, para que se estabeleça um justo distanciamento, e a razão cínica que renuncia ao poder de ação ${ }^{67}$, arte e arquitetura se entrecruzam em um campo minado de contradições e riscos éticos que podem desencadear desde o apagamento de realidades locais existentes até a neutralização de suas funções poéticas e políticas.

Nesse sentido, a configuração de um campo partilhado de práticas entre arte e arquitetura, que vem sendo reportado ao termo prática espacial, baseado na dialética sócioespacial elaborada por Lefebvre, informa leituras críticas cruzadas que passam pelo debate e construção de um aparato teórico comum.

O aspecto espacial que atravessa trabalhos de arte que abandonam o ambiente controlado das galerias e museus para assumirem o embate com o espaço público, ou aquele que permeia estruturas institucionais criando situações de coletividade e ações socialmente engajadas, acabam por transgredir, de forma mais evidente, os limites que os aproximam da arquitetura. Do mesmo modo, o emprego de práticas originadas no campo da arte e impregnadas de uma consciência contextual reportada ao termo site-specific, oferecem à arquitetura uma chance de repensar os meios nos quais opera sugerindo que, de forma equivalente, a arquitetura pode olhar para a arte e "mover-se para fora das fronteiras de seu campo em um lugar entre disciplinas” (RENDELL, 2008, p. 191, tradução minha) ${ }^{68}$, como apontado pela crítica de arte e arquitetura Jane Rendell, em Art and Architecture, a Place Between (2006).

Formulação de Hal Foster em “Questões de distância”, o capítulo de conclusão do livro Retorno do Real (2017).

No original: "to develop as a critical practice architecture must look to art, and move outside the traditional boundaries of its field and into a place between disciplines". 


\section{Práticas espaciais críticas}

A identificação da existência de um cruzamento estratégico entre arte e arquitetura, desde um campo partilhado de práticas que agem e se manifestam no espaço, ganha novos contornos com o debate em torno dos desdobramentos de trabalhos site-specific e de experiências propositivas de coletividade e participação da arte, a partir da última década do século XX. Os procedimentos empregados e os circuitos de produção e publicização desses campos disciplinares também se aproximam e passam a se sobrepor.

A transição de uma compreensão sobre o sítio e as camadas culturais, econômicas, sociais e políticas que informam e são informadas pelo espaço, faz com que Rendell se remeta à formulação de Lefebvre, e recorra ao termo prática espacial como elaborado pelo autor, ao qual adiciona a camada crítica para configurar um lugar entre a arte e arquitetura:

'Prática espacial crítica' me ocorreu em 2003, como uma forma de ajudar a descrever projetos localizados entre a arte e a arquitetura que, duplamente, criticassem esse lugar de intervenção, tanto quanto os procedimentos disciplinares nos quais operavam. Argumentei que tais projetos aconteciam em uma tripla encruzilhada: entre teoria e prática, entre público e privado e entre arte e arquitetura, e insistia em destacar três qualidades particulares dessas obras: a crítica, a espacial e a interdisciplinar. (RENDELLl, 2006, online, tradução minha) ${ }^{69}$

No original: “'Critical spatial practice' came to my mind back in 2003 as a helpful way of describe projects located between art and architecture, that both critiqued the sites into which they intervened as well as the disciplinary procedures through which they operated. In Art and Architecture (2006), I argued that such projects operated at a triple crossroads: between theory and practice, between public and private, and between art and architecture, and I was keen to stress three particular qualities of those works: the critical, the spatial and the interdisciplinary.” Acesso em 22 jul. 2019. 
De modo semelhante, a pesquisa de Jeremy Till, Tatjana Schneider e Nishat Awan, reunida no livro Spatial Agency. Other Ways of Doing Architecture (2011), que se organiza também como uma base de dados acessível por uma plataforma digital ${ }^{70}$, recorre à noção de espaço elaborada por Lefebvre para mapear casos exemplares que, em escala global, desafiam o senso comum sobre o que é arquitetura. Uma postura crítica do grupo às normativas da profissão, rigidamente reguladas no contexto britânico. Os pesquisadores sustentam que as ferramentas empregadas na produção arquitetônica se ampliaram e, consequentemente, é preciso uma revisão e expansão de seu escopo normativo.

Para melhor definir o que seria um escopo expandido por outras maneiras de se fazer arquitetura, a formulação tautológica de Lefebvre de que "o espaço social é um produto social” (LEFEBVRE, 1991, p.26, tradução minha) ${ }^{71}$ é tomada como indutora da desconstrução de três paradigmas. $\mathrm{O}$ primeiro refere-se ao fato de que o espaço social é por natureza coletivo, portanto jamais poderia ser associado a um projeto autoral descolado da contribuição de inúmeros agentes. O segundo compreende que o espaço social é dinâmico, não podendo ser relativo apenas ao edifício resultante, uma vez que abarca todo o processo e todas as circunstâncias implicadas em sua produção. Por último, o espaço social pressupõe sua raiz política, e é carregado por dinâmicas de interação, poder e controle que se amplificaram com o avanço e domínio das redes de comunicação e informação global.

No mapeamento proposto pela plataforma Spatial Agency, trabalhos realizados por não-arquitetos são igualmente considerados dentre os mais de 136 exemplos apresentados e comentados no livro, abrangendo um arco temporal que se inicia na esteira da contracultura, nos anos 1960, com os experimentos utópicos de grupos como Antfarm, Superstudio, Archizoom, e Haus-Rucker-Co., assim como grupos em atividade e reconhecidos no cenário internacional atual, como Atelier Bow Wow <imagem C2.2

Disponível em: https://www.spatialagency.net/. Acesso em 20 jul. 2019. No original: "(Social) space is a (social) product", que Lefebvre defende como uma obviedade cuja análise é da maior importância, uma vez que o espaço se apresenta como uma realidade própria e distinta, mas muito próxima, àquela assumida pelo processo global das commodities, do dinheiro e do capital. 
p.143>, Elemental <imagem C2.7 >, Haumlabor e Lacaton \& Vassal < imagem C2.1 p.142>, entre outros.

Três perguntas básicas estruturam a pesquisa de Spatial Agency e organizam o conjunto de características que aproximam as experiências catalogadas. "Por que?” revela as motivações e intenções de práticas que derivam do enfrentamento de problemas ecológicos, éticos, pedagógicos, políticos, e profissionais. “Como?” - determina quais operações e estratégias são empregadas nos casos estudados como apropriação, disseminação, empoderamento, conexão em rede, e subversão. "Onde?" - se relaciona diretamente com a noção de site, tanto como local geográfico quanto por sua noção expandida para o contexto que é atravessado por camadas sociais e metafóricas onde ações são propostas e realizadas. Portanto, “Onde?” abarca também os meios pelos quais essas ações se deslocam e se disseminam, considerando trabalhos que rompem as barreiras de produção e transmissão de conhecimento sobre arquitetura para reunir exemplos de estruturas que promovam novos sistemas organizacionais e parâmetros para a prática, além de apresentar grupos que atuam na mediação entre o projeto, as transformações físicas propostas e as relações sociais imbricadas no processo (AWAN, SCHNEIDER, TILL, 2011).

Não é por acaso que um artista como Antoni Muntadas parta de um procedimento semelhante e utilize pronomes interrogativos para provocar o público em relação aos contextos em que inscreve seu trabalho. Este é o cerne do trabalho intitulado Projeto (2007) <imagem C1.10 p.79>, no qual o artista catalão estabelece cruzamentos entre seu processo de pesquisa sobre um sítio e a forma que esse trabalho assume nos diversos meios pelos quais circula. Assim, suas perguntas se projetam como uma provocação para que o público atente para as condições do contexto que o cercam, com suas camadas sutis e narrativas invisíveis. Afinal, seja dentro de uma galeria ou museu, seja numa sala de aula ou no espaço urbano, o diagnóstico de Frederic Jameson a respeito da lógica cultural pós-moderna se impõe como um desafio que enfrenta, "necessariamente, uma posição política, implícita ou explícita, com respeito à natureza do capitalismo multinacional" (JAMESON, 1996, p. 29).

Trata-se, portanto, de uma crítica que compreende e questiona os modos de produção e consumo do espaço e da cultura, em seus diversos contextos de inserção. Questão 
claramente presente para uma instituição como o Canadian Centre for Architecture (CCA), preocupada em construir um arquivo de arquitetura com constante publicização de seu acervo em exposições, publicações e novas pesquisas, de modo a pautar discussões que problematizem, expandam e renegociem as convenções de inserção do pensamento arquitetônico, voltando-se para um diálogo cultural mais abrangente.

Fundado em 1979, o CCA tornou-se uma significativa plataforma de disseminação de conhecimento com função pedagógica, segundo o Spatial Agency, e possui em seu acervo os arquivos de Gordon Matta Clark, Cedric Price e Aldo Rossi, arquitetos e artistas com papel determinante na revisão crítica e criativa instaurada no debate arquitetônico a partir dos anos 1960. Conforme uma de suas curadoras residentes, Giovanna Borasi, uma ampla gama de novas ferramentas, conceitos e modelos operacionais em curso hoje foram formulados antecipadamente neste período e ecoam nos recentes trabalhos apresentados em duas exposições sob sua coordenação de pesquisa.

A primeira delas é Ferramentas para Ações. O Que Você Pode Fazer com a Cidade (2008), com curadoria de Borasi e de Miko Zardini, que, em sua itinerância, integrou o módulo “Modos de Agir” da X Bienal de Arquitetura de São Paulo, no Centro Cultural São Paulo (2013). A exposição reúne um repertório de novas ferramentas para o enfrentamento de problemas urbanos, conferindo importância política ao engajamento de grupos e comunidades que buscam soluções alternativas como forma de criticar as relações sociais e os modelos econômicos vigentes refletidos nas espacialidades urbanas.

The Other Architect (2017) dá continuidade a essa linha de pesquisa visando a construção de uma agenda cultural em que a arquitetura participe mais ativamente na construção das pautas contemporâneas, assumindo novas perspectivas de atuação. Para este fim, a exposição se voltou para os procedimentos empregados em novas abordagens profissionais, apurando e exibindo etapas processuais como "orçamentos, táticas para acessar recursos, planos de comunicação, atas de reuniões, rascunhos de projetos, declarações, correspondências, e estudos não publicados mais relevantes do que estudar os produtos finais" (BORASI, 
2015, online, tradução minha) $)^{72}$.

Essa diversidade de mecanismos, segundo o arquiteto Markus Miessen, faz com que o termo prática espacial crítica possibilite também a configuração de um território mais fluído de investigação entre campos, como comprovam os trabalhos da "documentarista Laura Poitras, da artista Hito Steyerl, da arquiteta e artista Celine Condorelli <imagens C3.8 p. 209 e C3.17 p.218>, do grupo de designers Metahaven, do coletivo ativista Ultra-Red e do arquiteto Teddy Cruz" (MIESSEN, 2016, p. 37-38).

Coeditor da coleção Critical Spacial Practice, juntamente com Nikolaus Hirsch, um dos editores do website e periódico E-flux Architecture, Miessen reivindica, por meio dessas publicações, um lugar de destaque para a crítica como uma ação complementar e não oposta à prática. Diversos críticos, artistas e arquitetos contribuíram com a coleção que reúne profissionais com pesquisas originadas em distintos campos do conhecimento e que estabelecem, segundo seu editor, correspondências e interlocuções na criação de um arquivo reflexivo e propositivo

Miessen afirma que o emprego do termo prática espacial crítica é capaz de abarcar um campo hibrido de produção no qual as fronteiras entre arte e arquitetura encontram-se já superadas. Esta hibridação conteria a "promessa central de unir um conhecimento multifacetado e de potência exponencial” (MIESSEN, 2017, p. 27) ao espacializar pesquisas transdisciplinares. Em função disso, Miessen (2016, p. 39, tradução minha) ${ }^{73}$ avalia que:

72 No original: "Reading the traces of these different creative processes-budgets, tactics for accessing resources, communication plans, meeting minutes, project drafts, mission statements, correspondence, unpublished studies-is more relevant here than studying the final products". Disponível em: https://www. cca.qc.ca/en/articles/issues/20/the-other-architect/50960/ another-way-of-building-architecture. Acesso em 15jul. 2019.

73 No original: “Moving toward a possible definition of critical spatial practice, one could argue that is central feature is a focus on the playful and culturally discursive potential of the relationship between architecture and related disciplines - first and foremost, art - in order to reinvigorate architectural production with cultural, social, and political criticism. It seeks to stablish a productive dialogue with other fields of knowledge by benefiting from the intrinsic friction that exists between them. It gains from complex and steady fertilization processes through intensive collaboration with diverse fields and practices, and vital interaction with its own situated context”. 
Para direcionar uma possível definição de prática espacial crítica, pode-se argumentar que sua característica central é um foco no potencial lúdico e culturalmente discursivo da relação entre a arquitetura e disciplinas correlatas - em primeiro lugar, a arte - para revigorar na produção de arquitetura com críticas culturais, sociais e políticas. Buscar estabelecer um diálogo produtivo com outros campos de conhecimento beneficiandose da fricção intrínseca existente entre elas. Ganhar com a complexidade e com processos de produção através da colaboração intensa entre diversos campos e práticas gerando interação vital com contextos específicos.

Ou seja, o que plataformas como Spacial Agency, Critical Spatial Practice e CCA vêm empreendendo é o reconhecimento da insuficiência da ênfase dada ao trabalho projetual e ao gênio do arquiteto como formuladores de soluções para os complexos problemas urbanos que se apresentam. Sem descartar a importância do legado histórico da profissão, e identificando uma inteligência intrínseca à disciplina, tratam de expandir e explorar fundamentos da prática que se relacionam à gestão sistêmica de processos e a modos alternativos para se intervir de forma transformadora e inventiva no espaço.

Tais características encontram paralelo na interpretação de Felicity $\operatorname{Scott}^{74}$ sobre uma possível inversão estratégica a partir de uma desobediência epistêmica que,

[...] desloca o papel da arquitetura de projetar formas elegantes, funcionais ou mesmo radicais, ou de se envolver com organizações e tecnologias inovadoras, para o de fornecer ferramentas políticas e estratégicas, competências tecno sociais e econômicas, dentro de um campo de batalha político expandido, institucional ou fluído, mas distintamente instável” (SCOTT, 2017, p. 49).

Felicity Scott é professora de arquitetura na Columbia University, onde é diretora do programa de doutorado em história e teoria da arquitetura, e co-diretora do programa de práticas críticas, curatoriais e conceituais em arquitetura (CCCP) na Escola de Arquitetura, Planejamento e Planejamento. 
Esse desvio de viés político e estratégico como potência para uma ação reconfigurada da prática arquitetônica é também tratado por Keller Easterling ${ }^{75}$ e sua investigação sobre a noção de "infraestrutura”. Para a autora de Extrastatecraft. The power of infraestrucure space (2016), as infraestruturas que hoje apreendemos são de ordem ubíqua, estão em todos os lugares, ao mesmo tempo que estão em lugar nenhum. Estabelecem uma relação direta entre o espaço físico percebido e os sistemas imperceptíveis que o determinam de forma ininterrupta e em expansão acelerada, assim como as tecnologias da informação.

Há, nos textos de Easterling, um jogo de linguagem que explora termos do universo digital para os ressignificar à medida em que passam a agir como conceitos, a exemplo da relação entre o software e sua interdependência para com o hardware. Para Easterling, mais do que o espaço físico apreensível (o hardware), o que determina a produção do espaço contemporâneo são os sistemas operacionais que replicam em escala global o espaço infraestrutural por meio de seus parâmetros de controle e governabilidade que resultam em edifícios, mas também em cidades inteiras erguidas como fórmulas reprodutíveis pelo globo. Um fenômeno que parece manter as possibilidades transformadoras da arquitetura à margem dos centros de decisão.

Dessa forma, seria possível compreender a existência de um campo inexplorado e estrutural da disciplina arquitetônica capaz de "projetar não somente objetos, mas também os protocolos entre objetos” (EASTERLING, 2012, p. 45), como um procedimento orientado a interferir nos circuitos que desencadeiam a produção do espaço.

Daí a afirmação de que:

Se o espaço matricial contemporâneo é uma arma secreta, é o segredo mais bem guardado de arquitetos e urbanistas, que são realmente treinados para criar espaço. Um repertório arquitetônico expandido que pode orquestrar múltiplos e manipular os parâmetros da organização talvez

75 Keller Easterling é arquiteta e escritora norte-americana, professora no programa de arquitetura da Princeton University, onde dirige o programa de Desenho Ambiental. 
esteja, ironicamente, muito próximo do coração da disciplina (EASTERLING, 2012, p. 45, tradução minha) ${ }^{76}$

A resposta, segundo a autora, estaria num enfoque sobre o meio, ou seja, sobre a forma como a arquitetura pode interferir na matriz que a afeta. Se o espaço se tornou informação, dificultando sua apreensão, uma inversão de abordagem voltada ao seu reconhecimento representaria uma ação de hackeamento que possibilitaria abrir brechas em sistemas de produção de informação.

Um procedimento de certa forma análogo à produção artística conceitual que proporcionou um deslocamento de interesse da produção do objeto de arte para suas questões e ideias, ou suas maneiras de agir no mundo. Tal questão se coloca de modo explícito no trabalho de um artista como Cildo Meireles, para quem a noção de circuito, explorada em Inserções em Circuitos Ideológicos. Projeto Coca-Cola e Projeto Cédula (1970), responde a questões fundamentais da prática artística.

Ao decalcar nas garrafas vazias de Coca-Cola instruções para utilizá-las como coquetel molotov, ou mensagens críticas para devolvê-las em circulação, e carimbando nas cédulas de 1 cruzeiro a pergunta “Quem matou Herzog?”, o artista evidencia o funcionamento dos sistemas de circulação, tornando-os inteligíveis. Ao mesmo tempo, pelo modo como recoloca esses objetos em circulação, o público se torna parte integrante do sistema de comunicação, participando do fluxo, ainda que involuntariamente, e multiplicando a ação também como relato oral.

Trata-se, portanto, de um modo de fazer e atuar que pressupõe uma noção alargada de estudo como estruturadora de sua poética, o que inclui,

[...] tanto a ideia de um esboço que demarca um projeto cuja realização efetiva se dará no futuro, como também pela via conceitual, a noção de um trabalho que já se realiza plenamente enquanto estudo, como um conjunto de instruções para ações. (MATOS; WISNIK, 2017, p. 13).

No original: "If contemporary matrix space is a secret weapon, it is perhaps a secret best kept from architects and urbanists who are actually trained to make space. An expanded architectural repertoire that can orchestrate multiples and manipulate the parameters of organization is perhaps, ironically, very close to the heart of the discipline”. 
A ideia de que um projeto não precisa se materializar para que já aconteça no mundo é também uma crítica ao próprio sistema artístico, assim como a inserção do trabalho através de um objeto que já está no mundo para, a partir dele, incitar ações, expõe o questionamento sobre o lugar do trabalho de arte.

Projeto Coca-Cola e Projeto Cédula produzem um desejado efeito político que se alastra por diversas camadas de comunicação, causando um distúrbio em atividades coditidianas e ganhando sentido justamente por assumir essas atividades corriqueiras como lugar do trabalho durante o período de maior tensão e repressão da ditadura militar.

Mas, a medida em que a dematerialização do objeto de arte passa a significar uma valorização de práticas e processos, de situações e encontros, novas formas de proximidade com contextos sociais são propostas como instâncias de problematização dos espaços e campos de atuação. Esse claro estreitamento de limites da arte com a arquitetura acontece num momento em que esta última também ensaiava novos modos de inserção social e política, criticando sua adesão atávica aos mecanismos de dominação do Estado e do mercado que controlam grande parte de sua produção. Esse curto-circuito entre campos, vale atentar, pode também expressar uma contradição no que diz respeito à potência crítica de ambas as práticas.

A revisão dos protocolos tradicionais da arquitetura, desde o último quartel do século XX, que se manifesta hoje em formas mais plurais e abertas de organização da produção arquitetônica, quando reportadas ao termo prática espacial crítica, são balizadas por uma interpretação otimista da leitura de Lefevbre por parte da crítica arquitetônica. Assim, seja por meio de processos multidisciplinares, coletivos e colaborativos que compreendem tanto um campo discursivo da arquitetura - curadorias, estruturas institucionais e pesquisas - seja por ações e intervenções que consideram e mobilizam as realidades socioculturais em que se inserem, seria possível afirmar um caráter propositivo e criticamente engajado dessas práticas com a produção do espaço.

No entanto, essa face mais utópica do pensamento lefebvriano é duramente criticada por autores que enxergam nela uma interpretação excessivamente positiva das possibilidades emancipadoras de experiências participativas, que são igualmente cooptadas por instâncias de poder.

Do mesmo modo a defesa de Lefebvre sobre as vantagens 
de flexibilidades espaço-temporais, teria se tornado um componente essencial da agenda neoliberal, assim como as possibilidades redentoras do cotidiano urbano parecem distantes no cenário atual, marcado por duros processos de gentrificação.

Segundo Stanek, tais abordagens não significam interpretações equivocadas dos escritos de Lefebvre, uma vez que essas questões não podem ser explicadas pela hermenêutica de seus escritos. No entanto, não deixam de ser questões sensíveis ao seu pensamento, que foi produzido em diálogo próximo com arquitetos e urbanistas, num momento em que se procuravam caminhos de renovação da imaginação arquitetônica para além das condições de instrumentalização do projeto a serviço do planejamento funcionalista, alvo de sua crítica mais implacável.

A negação da cidade planejada e funcional, subentendida na condição de "totalidade aberta" do espaço, elaborada em O direito à cidade (1968), expressa a crença de Lefebvre na pulsão transformadora que a sociedade urbana seria capaz de empreender por meio do emprego espontâneo de um potencial criativo presente na experiência vivida. Dimensão esta que aproxima arte e vida, e encontra na arte os elementos "concebidos como a capacidade de transformar a realidade, de apropriar ao nível mais elevado os dados da vivência, do tempo, do espaço, do corpo e do desejo" (LEFEBVRE, 2016, p. 124).

Portanto, os fundamentos do pensamento de Lefebvre, apropriados pela crítica arquitetônica, se apoiam na potência de sua construção epistemológica sobre o espaço que é produzido e praticado por diversos agentes configurando um campo transdisciplinar de prática. Um aparato teórico que favorece as análises de trabalhos recentes que desafiam categorias e distendem limites disciplinares ao adotarem um repertório ampliado de práticas, meios e circuitos de produção e circulação, e que se inserem num debate cultural mais abrangente.

Nesse sentido, o emprego do termo prática espacial crítica representa menos uma busca de validação para uma nova categoria e mais a reivindicação de um lugar fluido e indisciplinado de ação, ao qual esta tese recorre como apoio para as análises a seguir. 



\section{Coleção de referências}




\section{C1.1 Learning from Las Vegas (1972) Denise Scott Brown, Robert Venturi, and Steven Izenour.}
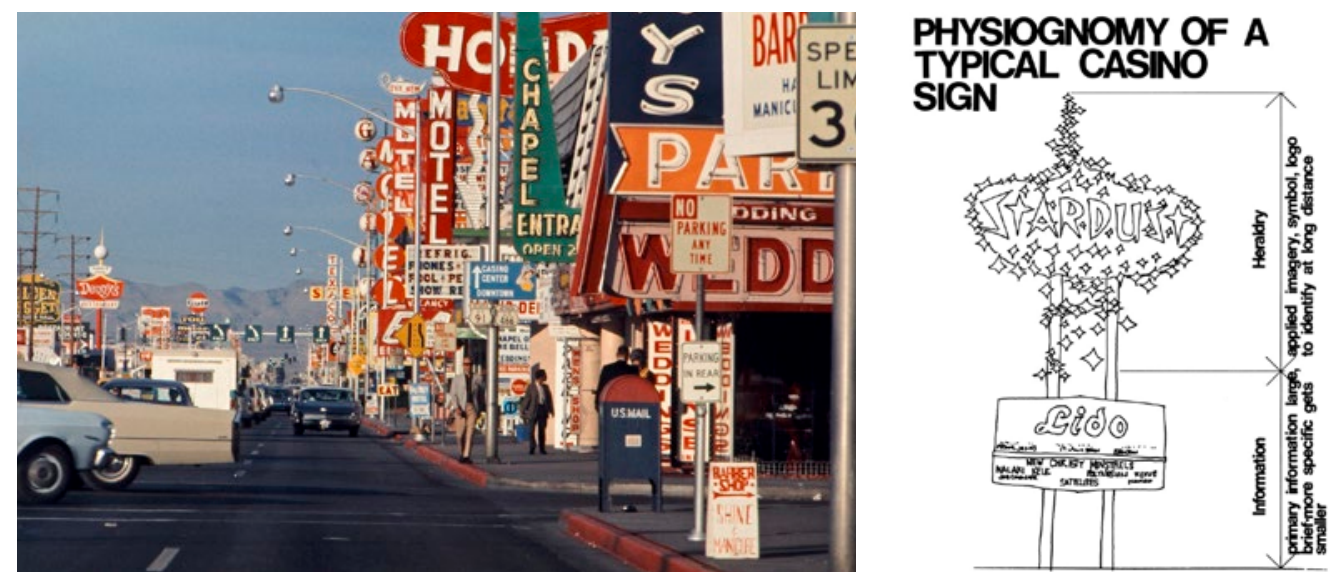

Nossa abordagem é não tentar ser heroico, não ser necessariamente revolucionário. Muitas vezes era apropriado ser heroico e revolucionário nos primeiros dias do modernismo, mas também há momentos em que a mudança evolucionária faz sentido. É por isso que adoramos começar pelo que está aqui, pelo vernáculo comercial da rodovia americana, é pelo comum e convencional que podem ser relevantes.

Robert Venturi

Segundo Koolhaas, Aprendendo com Las

Vegas foi o último livro manifesto sobre a arquitetura e o primeiro de uma série de livros que vieram a reboque de sua abordagem sobre a cidade real como campo de pesquisa e aprendizado.

O livro se estrutura sobre uma formulação que tem como origem o choque entre duas máximas do movimento moderno: a relação entre "ornamento e crime" e "a forma segue a função". Ao excluir o ornamento e derivar a forma a partir de sua função, os requisitos funcionais passaram a ser distorcidos para que se alcançassem formas expressivas. Com isso, a principal dedução do livro foi apontar os dois extremos resultantes dessa equação, o "pato" como edifício que distorce completamente seus pré-requisitos funcionais, resultando num todo expressivo, e o galpão decorado como o edifício genérico de aparência funcional que depende da aplicação de elementos decorativos para se tornar expressivo.

Em uma entrevista de 2002, Venturi e Scott-Brown reiteram sua defesa da importância da iconografia como elemento arquitetônico pré-existente à abstração estética do século XX, a exemplo dos hieróglifos egípcios, dos painéis barrocos católicos, e do vernáculo comercial americano. Eis o manifesto contido no livro, que conclama os arquitetos a não se constrangerem $\mathrm{e}$ a assumirem o papel comunicativo da arquitetura, acomodando a função de modo mais flexível. Portanto, a intenção da dupla nunca foi proclamar a morte da arquitetura, mas a morte da arquitetura como escultura.

Trata-se também de um livro sobre a cidade, que abarca a polêmica de se eleger Las Vegas e seus excessos como modelo, $\mathrm{e}$ a ironia decorrente desta escolha - aprender entre a atração e a repulsa. Realizado como uma plataforma de ensino a partir de um estúdio da Universidade de Yale, o livro se organiza em dois momentos resultantes da pesquisa. Um primeiro examina o espraiamento urbano, a tipologia comercial e os elementos comunicativos da via comercial a partir da experimentação com os meios de registro e representação mais adequados, de modo a dar conta desse fenômeno urbano que pressupõe o movimento e a velocidade dentro de um automóvel. A segunda processa esse material e realiza leituras comparadas e desenhos analíticos dos quais se depreendem as conclusões.

Em sua segunda edição, o livro trata da cidade e sua mudança radical. Reaprender com Las Vegas, 25 anos depois, significou constatar a perda de sua relevância em comparação a sua "era clássica". Hoje o espraiamento se converteu em adensamento, a strip virou um boulevard, o estacionamento passou a ser um jardim, o neon foi substituído pelo pixel, a iconografia pela cenografia, criando um todo exótico, uma Disneylândia, ou um lugar não real. 


\section{C1.2 Every Building on the Sunset Strip (1966) Edward Ruscha}

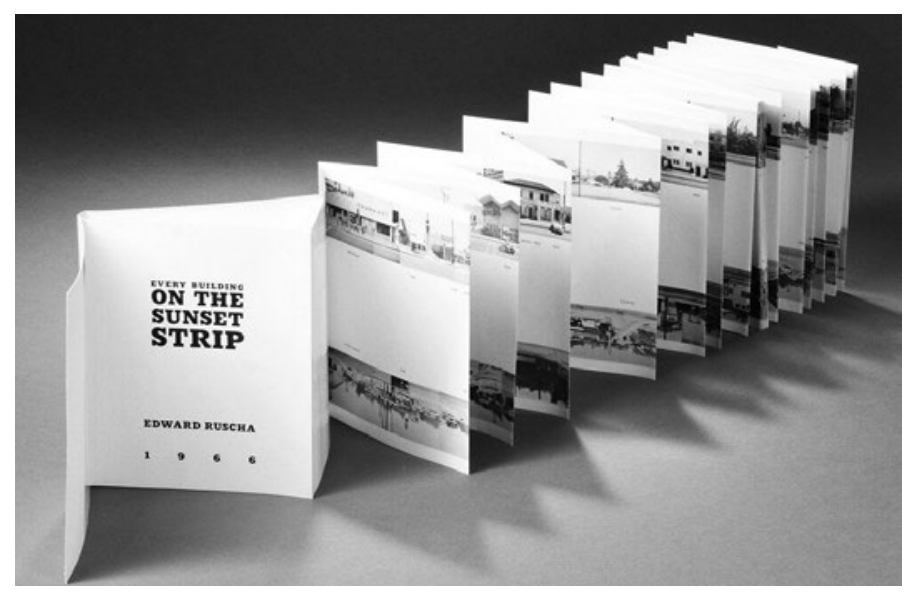

Eu eliminei todo o texto dos meus livros quero um material absolutamente neutro. Minhas fotos não são tão interessantes, nem o assunto. São simplesmente uma coleção de fatos; meu livro é mais como uma coleção de readymades.

Edward Ruscha

Every Building on Sunset Strip se inscreve numa série de livros produzidos por Edward Ruscha entre 1962 e 1971. O primeiro deles foi Twentysix Gasoline Stations (1962), no qual apresenta uma amostragem aleatória de fotos de postos de gasolina de beira de estrada tiradas no trajeto entre Los Angeles e Oklahoma City. Os postos de gasolina são sistematicamente registrados de modo distanciado e não emocional, como uma documentação democrática de elementos da cultura pop do oeste norte-americano, com letreiros e características ordinárias que interessavam ser apropriados como objetos estéticos.

$\mathrm{O}$ artista tratava seus livros como readymades. Todos medindo aproximadamente $18 \times 14 \mathrm{~cm}$, apresentavam apenas o título na capa, nenhum texto a mais. Eram elaborados como objetos acessíveis, simples, de tiragem industrial, com aspecto profissional, mas comercial, e feitos para serem vendidos como um produto de massa e não como um livro de artista com características artesanais e únicas.

O título precedia o projeto, e todas as decisões eram tomadas de antemão, uma vez que o conceito era o dado mais importante do trabalho, e sua confecção não dependia das habilidades do autor. Portanto, não se tratava de fotos artísticas, pois o meio não era a questão. Isto explica o fato de Every
Building on Sunset Strip ter sido selecionado por Sol Lewitt para acompanhar seu texto Paragraphs on conceptual Art (1967), publicado na revista Artforum, no qual Lewitt reflete sobre sua prática elaborando questões gerais para a arte conceitual.

Ao contrário da abordagem aleatória de publicações anteriores, Ruscha sistematiza um método para realizar Every Building on Sunset Strip. Após perceber a impossibilidade de realizar o trabalho a pé, cria um aparato atrelado a seu carro para fotografar e avançar o filme automaticamente, gerando todos os quadros que retratam cada um dos edifícios ao longo das 2,5 milhas que compõem a "strip".

O livro, quando fechado, era semelhante aos outros, mas se abria por meio de uma dobra sanfonada que revelava uma imagem contínua de toda a extensão da via. $\mathrm{O}$ conjunto da fachada sul foi disposto na parte superior, e o da norte, espelhado abaixo, de cabeça para baixo, e sob ambas foi anotado o número de cada imóvel. As fotos tiradas quase ao meio dia conferiam um aspecto chapado ao conjunto que, sem sombras não revelavam volumes ou profundidades. Segundo Ruscha, isto fazia com que a grande fachada comercial parecesse não ter nada por trás, como um cenário de filme de John Ford - uma grande referência para o artista.

O que vemos são restaurantes, farmácias, casas de show, galerias de arte, e as potenciais histórias do cotidiano que essa fachada contínua acolhe. Não há um interesse específico por um edifício, ou numa tipologia em especial, mas pelo conjunto não hierárquico e no registro de Los Angeles num momento em que crescia e se espraiava rapidamente. 


\section{C1.3 Rights of Passage (1995-1998) Flyer (1990-) \\ Martha Rosler}

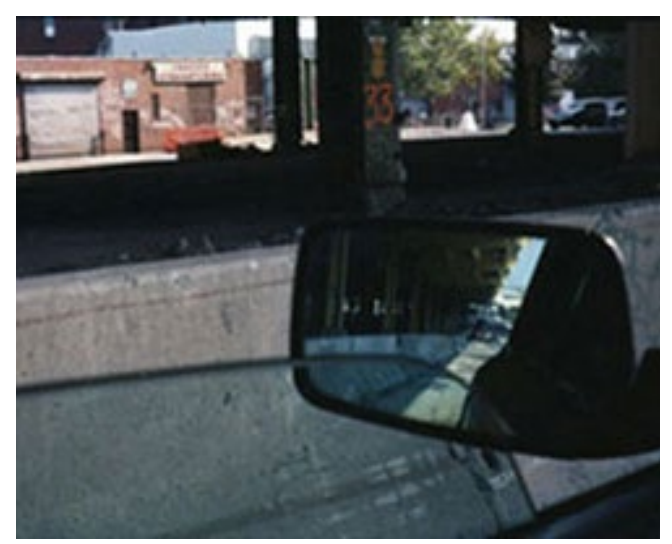

As duas séries de fotos de Martha Rosler foram reunidas em dois livros publicados, ambos com textos de abertura de Anthony Vidler. Em Rights of Passage (1997), a artista apresenta fotos panorâmicas que exploram a desorientação e a impossibilidade de uma perspectiva com escape para 0 olhar, que é confrontado a todo tempo por obstáculos: trânsito, barreiras de concreto e a mesmice do entorno.

Roesler desconstrói o ideal arraigado na cultura norte-americana, que associa a autopista à modernização, ao progresso e à liberdade do viajante sem destino. Em Travel Stories (2002), a artista produz uma reflexão sobre o deslocamento humano como um fluxo massivo pelo planeta, analisando as condições dos indivíduos e seus corpos como "o átomo ordinário no sistema" (ROESLER, 2002, p. 132). O transporte aéreo, metroviário ou em veículos particulares, presente em suas fotografias, é descrito por ela como um "quadro espacializado para a apreensão de fluxos" (ROESLER, 2002, p. 132). Os dois ensaios são, para Roesler, incompletos, à medida que não dão conta de condições estruturais e históricas, portanto a artista busca, por meio da escrita, adensar camadas de suas fotografias, expondo o controle dos corpos em fluxo, onde "estradas e ruas, em vastas áreas metropolitanas, são como uma estória maior, cuja dura realidade me controla muito mais do que eu gostaria, apesar da minha capacidade de decidir onde e quando entrar" (ROESLER, 2002, p. 112).

A liberdade, antes associada à viagem de carro, é retratada agora pela frustração

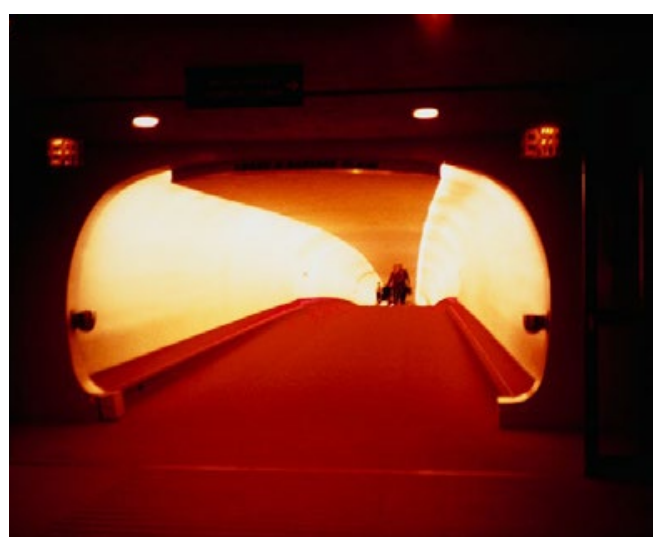

e pela necessidade de atenção constante do motorista ao volante, submetido a radares, satélites e pedágios.

$\mathrm{Em}$ In the Place of the Public: Observations of a Frequent Flyer (1998), o foco são os aeroportos e sua dialética entre liberdade e controle dissimulado de diferentes modos no espaço. Segundo Vidler, o Terminal TWA (1954) do aeroporto JFK, em Nova lorque, projeto do arquiteto Eero Saarinen, embora tenha sido pensado como um facilitador do fluxo de passageiros, surge nas imagens de Rosler como "um espaço que não comporta mais o discurso que embasou seu desenho" (VIDLER, 2002, p. 180).

A efetivação do espaço abstrato, engendrado pelo modernismo, como Henri Lefebvre observou e Rosler enfatizou em seu próprio trabalho, sempre esteve apoiado numa utopia de superação das diferenças sociais e culturais através do desenvolvimento tecnológico. Desenvolvimento este indissociável de consequências do avanço do capitalismo sobre o espaço, que acabaram por desencadear uma explosão da cidade. "Como Lefebvre colocou, contestando a aceitação distanciada de Sigfried Giedion acerca do espaço abstrato, em Espaço, Tempo e Arquitetura (1964), o espaço abstrato revela suas capacidades opressivas e repressivas em relação ao tempo. $\mathrm{O}$ espaço abstrato rejeita o tempo como uma abstração exceto quando o tempo diz respeito ao trabalho, a produção de coisas e de maisvalia -, e é reduzido a restrições de espaço, horários, corridas, travessias e cargas, como afirma Rosler" (VIDLER, 2002, p. 180). 


\section{C1.4 The Educational Complex (1995) Mike Kelley}

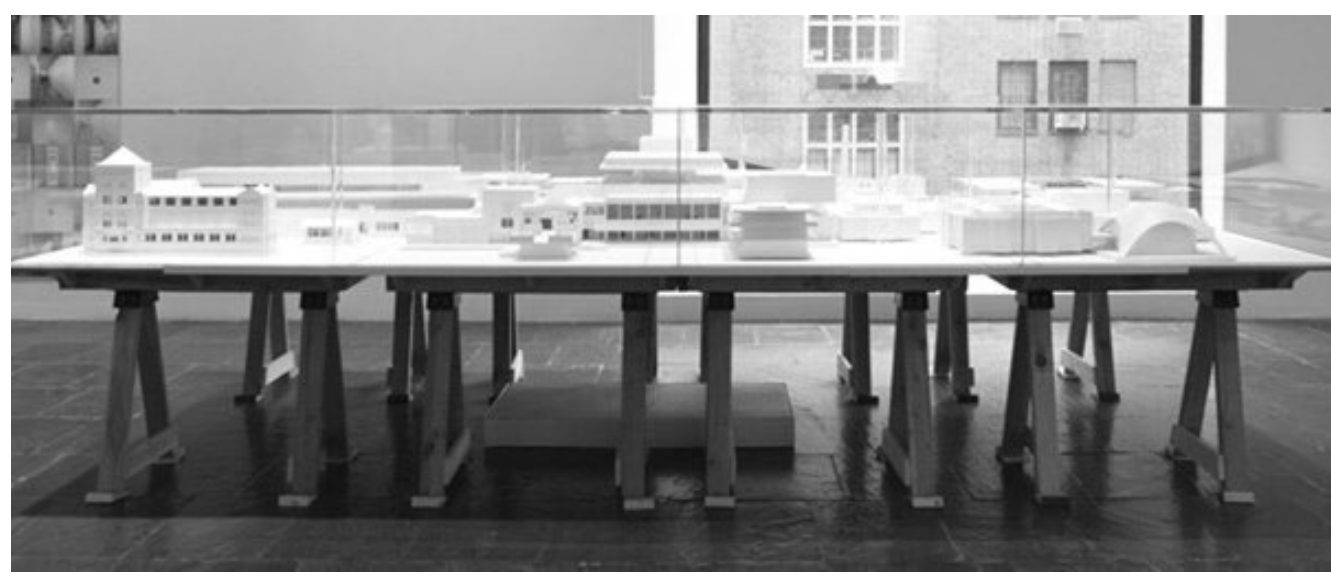

The Educational Complex (1995) é composto por modelos individuais de todas as escolas que já frequentei, além da casa em que cresci. As elevações exteriores são bastante precisas, com base em fotografias e, em alguns casos, plantas baixas. Os interiores, por outro lado, são radicalmente incompletos, refletindo minha incapacidade de lembrar o que estava lá. Essas seções de arquitetura não lembradas são deixadas em branco, são lacunas, espaços a serem preenchidos.

Mike Kelley

Essa colagem de espaços é materializada numa grande e complexa maquete na qual fragmentos são sobrepostos e fundidos numa superestrutura. Kelley procura, com esse procedimento, se reconectar com suas memórias reprimidas, cuja origem são os processos educacionais mentalmente abusivos pelos quais passou e que são explicitados no espaço arquitetônico. Ou seja, esses espaços são, para o artista, o mais autêntico espelho das instituições que os reproduzem.

Kelley enfatiza, com a construção desse modelo, a contradição entre o almejado sentido de integridade representado pela funcionalidade arquitetônica dos edifícios públicos e a realidade de "nossas verdadeiras condições sociais caóticas" (KELLEY, 1996, p. 38) ao vivenciarmos experiências dentro deles.

Vidler localiza este trabalho numa linhagem da produção artística que lida diretamente com a arquitetura, mobilizando-a metafórica e literalmente. Segundo o autor, esse é um fenômeno recorrente desde os anos 1960, quando Rosalin Krauss formulou o termo 'campo ampliado' na tentativa de abarcar transformações da produção tridimensional.

No entanto, o modelo crítico elaborado em The Educational Complex supera limites disciplinares para adentrar no campo arquitetônico e seus códigos, de modo a desvelar as complexas associações entre a sociedade e suas manifestações espaciais, assim como apresentar o espaço como produto das patologias que representa e desencadeia.

Por esse motivo, Vidler destaca a importância da escolha da maquete como modelo de linguagem empregado, no qual o artista "confia em seu efeito, precisamente em suas dimensões arquiteturais, e suas mensagens são codificadas em termos que seriam incompreensíveis fora do discurso da arquitetura... na verdade, ele para precisamente momentos antes, quando poderia ser reconhecido como projeto real, no momento onde a ambiguidade do possível e impossível retém seu status de crítica e seu lugar no contexto da arte" (VIDLER, 2001, p.160). 


\section{C1.5 Hard Space / Soft Space (1970) \\ Viena, Austria \\ Coop Himmelb(I)au}

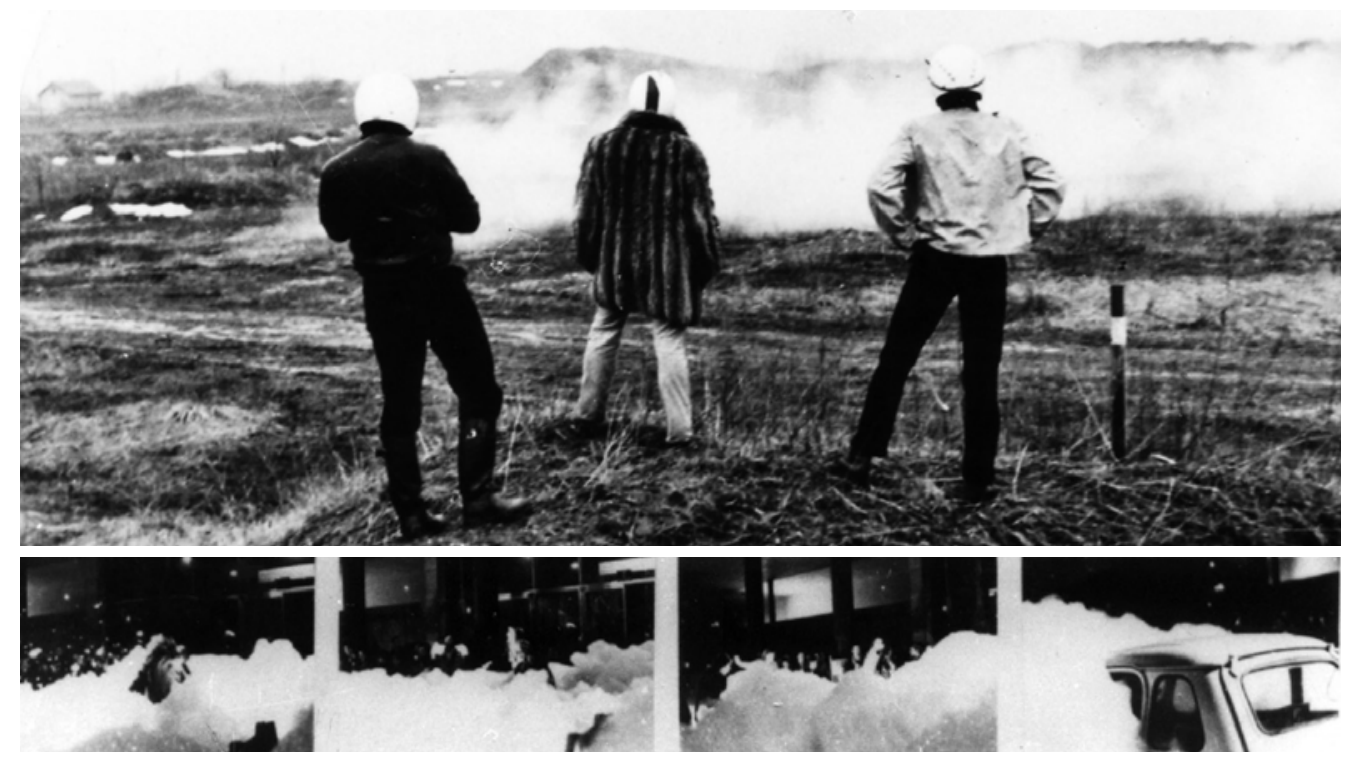

Hard Space (Duração: 10 min.)

Através do batimento cardíaco de 3 pessoas, 60 explosões foram liberadas. Os explosivos foram dispostos em linhas de $2 \mathrm{~km}$ de comprimento em todo o campo. Para a duração de 20 batimentos cardíacos, um 'espaço' é criado.

Soft Space

Espaço realizado em espuma/ $1.200 \mathrm{~m}^{3}$ por minuto.

Coop Himmelb(l)au

Os registros fotográficos documentam dois experimentos performáticos com uso de tecnologias responsivas que foram realizados pelos três integrantes do grupo Coop Himmelb(I)au, em 1970. Na primeira, vemos Wolf D. Prix, Helmut Swiczinsky e Michael Holzer no momento em que suas batidas de coração, captadas por microfones cardíacos, são transmitidas para acionar três cargas explosivas, construindo um espaço temporário e "instantâneo". No segundo, vemos uma onda de espuma engolir a rua, os corpos e automóveis em uma rua de Viena.

O grupo descreve seus experimentos como um tipo de escrita automática, num sentido surrealista. Uma escrita realizada por gestos cegos que são traduzidos em formas lineares ou tridimensionais, de modo a inscrever literalmente a linguagem corporal no mapa da cidade.

Anthony Vidler assinala também importante produção gráfica do Coop Himmelblau como campo de investigação e deslocamento do lugar de suas ações, utilizando colagens para revelar um processo de investigação que "funde fotografias de corpos na textura dos planos da cidade, e ilustram dramaticamente o desejo de dissolver o corpo autoritário do arquiteto" (VIDLER, 1990, p. 8).

Há, hoje, uma nítida distância entre os trabalhos iniciais do grupo e sua produção de edifícios coorporativos e públicos com programas complexos que são executados por meio de uma hiperperformance técnica, resultando em formas extravagantes. Esses edifícios parecem indicar uma perda da capacidade social experimental dos primeiros trabalhos do grupo em proveito de um pós-modernismo comercial.

Alguns desses experimentos iniciais ainda marcam um período de ânimo com as possibilidades tecnológicas como potencial gerador de interação no espaço público, um espaço rico de intersubjetividade, que encontra um potente eco no atual momento de onipresença digital, onde tecnologias responsivas e a internet das coisas enredam o usuário em seus "scripts" e os distanciam de pensamento e ação inovadores e transformadores do espaço. 


\section{C1.6 Installation at the Santa Monica Museum of Art (2008) Michael Asher}

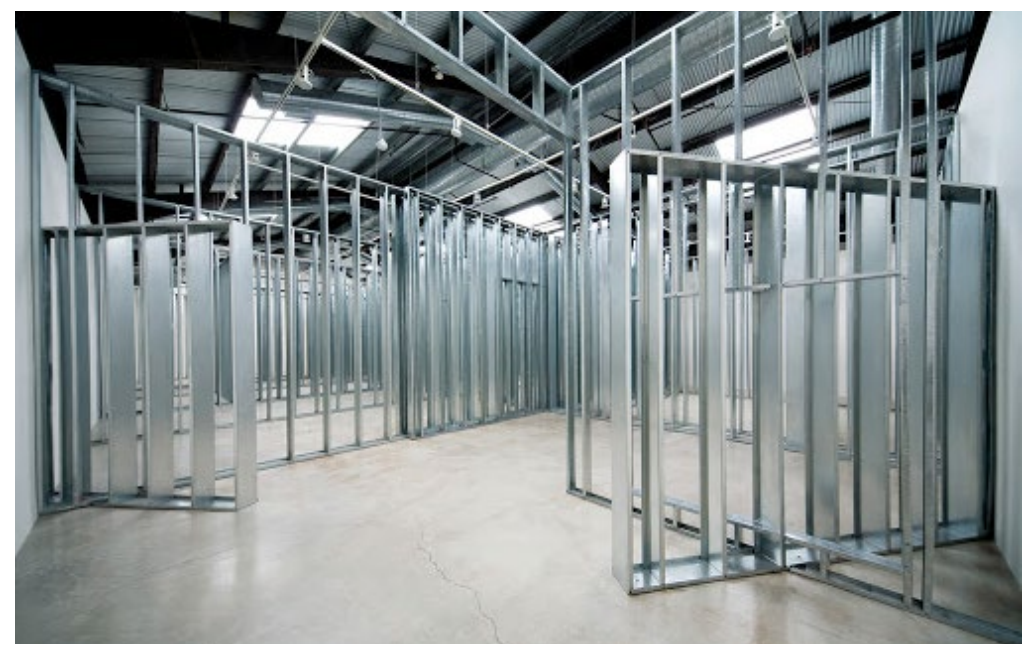

Os primeiros trabalhos de Michael Asher, nos anos 1970, já desestabilizavam a ordem do espaço expositivo desconstruída pela remoção de camadas de pintura branca sobre as paredes, deixando apenas o reboco aparente. Em 1974, na Galeria Claire S. Copley, em Los Angeles, o artista apenas removeu uma parede para que quem entrasse no espaço pudesse ver a área de trabalho anexada ao espaço expositivo, revelando as normalmente invisiveis operações comercias realizadas pelos galeristas.

As intervenções de Asher se davam no âmbito material e espacial das galerias, partindo de elementos já presentes no local de exposição, de modo a despertar a atenção dos espectadores para as condições ocultas que impactam na maneira como nos relacionamos com as obras de arte, estendendo-se para questionamos sobre como e por que as valorizamos. Com seus procedimentos de reconfiguração do espaço, revelavam-se camadas socioeconômicas que afetam a arte e a função pública de museus e instituições culturais, como "uma investigação epistêmica do status e da condição de produção de objetos estéticos" (KWON, 2009, p. 44).

Uma de suas últimas grandes intervenções aconteceu no Museu de Arte de Santa Mônica, que teve seu salão expositivo totalmente ocupado por um grande labirinto de estruturas de alumínio leve, formado por esqueletos utilizados para a construção de paredes drywall, conferindo uma aparência inacabada, porém organizada, ao todo. Para percorrer o espaço era preciso, muitas vezes, atravessar por entre as hastes verticais, cuidando para não tropeçar em sua base, num percurso incerto entre espaços amplos e confinamentos estranhos e desconfortáveis. A depender do ponto de vista, a sobreposição de camadas também oscilava entre a opacidade e a transparência, entre massa e volumes abertos. Mas essa distribuição não é aleatória. Há uma premissa conceitual que organiza a distribuição dos obstáculos, e é informada pelo posicionamento simultâneo de todas as paredes montadas e desmontadas, por todas as exposições que já ocuparam o salão, como uma revelação da história por trás dos complexos processos institucionais, dos projetos museográficos, do acúmulo de materiais e das negociações logísticas necessárias para a existência do museu. Installation at the Santa Monica Museum of Art, segundo Miwon Kwon (2009, p. 53), no texto para o catálogo da exposição, "fornece ao espectador a oportunidade de ver e encontrar fisicamente a mecânica das convenções de exibição à medida que elas mudam em relação à contingência do tempo. Mas sua qualidade provisória, mesmo fantasmagórica, como contornos estruturais, como paredes inacabadas, parece adequada à tarefa de revelar a temporalidade da arquitetura de exposições. Ao enfatizar a impermanência dessas paredes através de sua aparência oca literalmente transparente, Asher ressalta a transitoriedade do que comumente parece permanente e estável, incluindo, em última instância, a instituição do próprio museu". 


\section{C1.7 Food (1971) \\ Nova lorque \\ Gordon Matta-Clark, Carol Goodden, Tina Girouard, Suzan Harris e Rachel Lew}

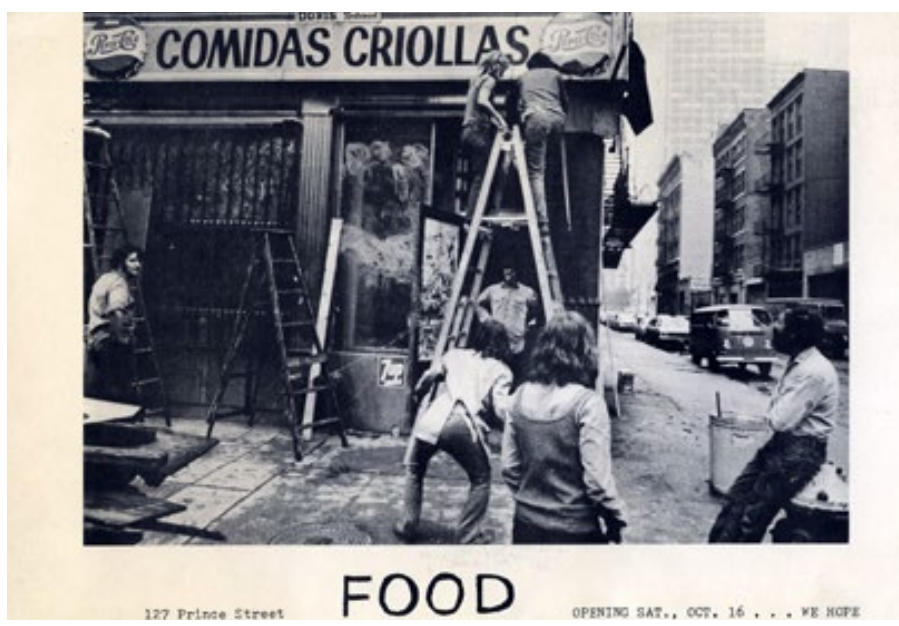

Quando Gordon Matta-Clark chega à

Nova lorque, no início dos anos 1970, a cidade vivia uma grave crise com falência institucional, violência e áreas degradadas.

É no SoHo esvaziado, um bairro formado por galpões industriais e edifícios de ferro fundido, antes ocupados por fábricas e tecelagens, que o arquiteto recém-formado na Cornell University se estabelece, sustentandose inicialmente como empreiteiro, reformando e negociando espaços convertidos em residências e galerias.

É nesse ambiente, em meio a uma comunidade de jovens artistas, que Matta-Clark começa a desenvolver o seu trabalho artístico, informado pelas operações de extração e decomposição física da arquitetura, e pela relação entre propriedade e apropriação, endereçando questões como o espaço social e seu uso.

Iniciativa da artista e dançarina Carol Gooden, e gerido por uma cooperativa de artistas, o restaurante Food representa um importante momento de atravessamento dessas questões. Matta-Clark faz o projeto e a reforma do espaço que já havia sido um restaurante popular, e durante a obra produz seu primeiro fragmento de edifício.

Wall sandwich (1971-1972), formado a partir de uma extração de parede que resultou da abertura de uma janela de serviço, é uma colagem de materiais brutos que revela as entranhas do edifício, com suas camadas de pregos, chapas e pintura. Utilizado depois como uma mesa de apoio do restaurante, se tornou a matriz a partir da qual Matta-Clark intuiu a possibilidade de seguir executando cortes.

Este e outros cortes integraram uma exposição na galeria 112 Greene St. - estúdio e espaço de exposição gerido por MattaClark e Jeffrey Lew - cada fragmento era acompanhado de uma fotografia que estabelecia uma relação entre peça e seu negativo. De fato, os fragmentos despertam a atenção para o que está além de sua materialidade, remetendo ao ambiente arquitetônico do qual antes fizeram parte, e "fornecem uma lição objetiva sobre os modos como a arquitetura e, por associação, a propriedade assumem uma função constitutiva na recepção da arte e vice-versa" (LEE, 2001, p.56).

Inaugurado no outono de 1971, rapidamente Food tornou-se um ponto de referência devido à hospitalidade, ao baixo custo da refeição servida em horários flexíveis e à oferta de trabalho em meio período a artistas, de modo que ainda tivessem tempo para produzir. Mas Food também foi um catalizador da cena artística e comunitária que se formava na vizinhança, promovendo eventos e performances, e fazendo da própria cozinha e do ato de comer um experimento performático para a convivência. Uma intervenção que assumiu e enfrentou as condições objetivas do mercado imobiliário, as relações de trabalho e a gestão dos negócios para criar um espaço de apoio e acolhimento a uma comunidade de artistas, alimentando sua subsistência. 


\section{C1.8 244 East 13th Street (1980-1981) Nova lorque Group Material}

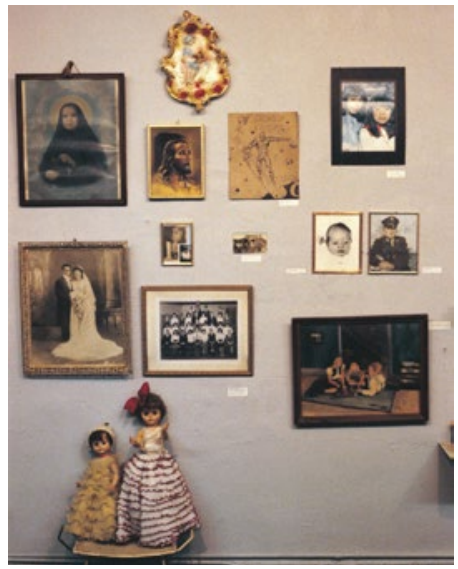

Que política informa os entendimentos aceitos sobre arte e cultura? Como é feita a cultura e para quem é feita?

Group Material

O Group Material (1979-1996) foi uma prática coletiva pela qual passaram e participaram diversos artistas. Insatisfeitos com a filiação elitista do mundo da arte, o grupo privilegiava a ação coletiva, adotando diversas estratégias para levar a produção artística a um público mais amplo, ao mesmo tempo em que propunham uma ação crítica e politizada que se contrapunha ao mercado, que ressurgia com força naquele momento - tendo em vista a passagem do período progressista da década de 1960 para o desmanche conservador das políticas econômicas e cultuais da Era Reagan (1981-1989).

O grupo experimentou diversos meios, da mobilização de espaços para anúncios comerciais à divulgação de press-releases, de curadorias ao desenho completo de exposições, sempre entrecruzando camadas visuais e discursivas. Desse modo, anteciparam uma série de questões ainda atuais para a arte, como práticas relacionais e participativas, o envolvimento com situações culturais específicas e a produção de instalações ou verdadeiras "exposições dentro de exposições" em bienais e museus, como forma de expor o vínculo entre política e cultura.

A primeira ação do Group Material foi alugar um espaço comercial para montar uma galeria que serviria como um laboratório para o próprio grupo. O local escolhido foi uma loja, cujo aluguel era acessivel para o grupo, no setor hispânico do bairro de East Village, em Nova lorque.

The People's Choice (Arroz con Mango) (1981) marcou a atuação do grupo nessa galeria. O grupo, então formado por Hannah Alderfer, Julie Ault, Patrick Brennan e Tim Rollins, entre outros, procurou estreitar sua relação com a comunidade local, de certo modo reagindo aos efeitos da gentrificação do bairro dos quais os próprios artistas e o circuito de galerias eram fomentadores.

Junto com crianças que falavam espanhol, o grupo visitou moradores do quarteirão e os convidou a participar da exposição, tomando emprestado objetos que estavam pendurados em suas casas e que normalmente não seriam vistos numa galeria de arte. A exposição era estetica e politicamente inovadora, e apresentou um acúmulo de objetos dos mais variados: santos, bibelôs, itens colecionáveis, posters, fotografias e arte popular. Ocupando todas as paredes, do piso ao teto, cada objeto era acompanhado de uma etiqueta que identificava o proprietário e a história daquele objeto. $\mathrm{O}$ subtítulo Arroz com Mango, uma expressão cubana que quer dizer "que bagunça", sugerido por uma participante, dá contornos claros à essência do projeto: "Ao rejeitar o papel do artista como fabricante, eles se tornaram outra coisa - produtores, organizadores, intérpretes de arte e de outros artefatos, até mesmo 'trabalhadores culturais'. Eles mobilizaram a exposição como um local ativo onde todas as coisas estavam sob escrutínio: poder institucional, estética, valor cultural e discurso político" (GREEN, 2018, p.18). 


\section{C1.9 Associação Arte Útil -Museu de Arte Útil (2011-) Tania Bruguera}

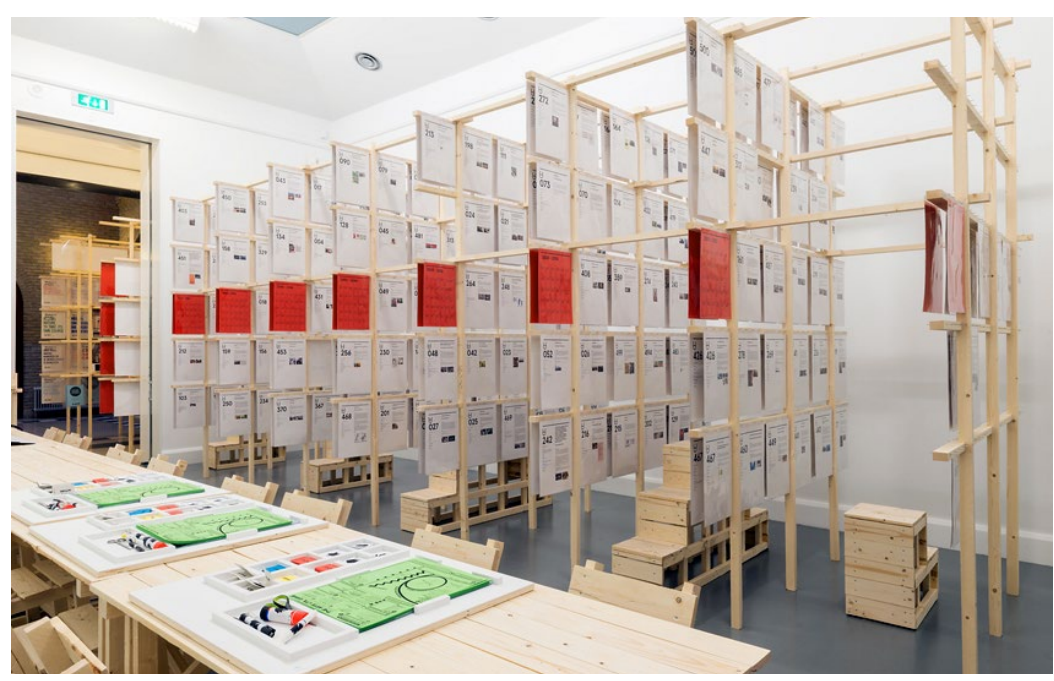

O sentido da Arte Útil é imaginar, criar, desenvolver e implementar algo que, produzido na prática artística, oferece às pessoas um resultado claramente benéfico. Isso é arte porque é a elaboração de uma proposta que ainda não existe no mundo real e porque é feito com a esperança e a crença de que algo pode ser feito melhor, mesmo quando as condições para que isso aconteça ainda não estejam lá.

Tania Bruguera

A artista cubana Tania Bruguera acredita que a arte ainda oferece um espaço protegido, ou uma arma de proteção cínica, para o dissenso criativo. Embora a artista compreenda que a arte per se, como proposição, não é suficiente para intervir num mundo autoritário, ela a utiliza como uma ferramenta para enfrentar a neutralização de instâncias democráticas por estruturas de poder.

Por esse motivo, Bruguera direciona seu trabalho para uma política efetiva, que faça sentido no tempo histórico. Assim, ela descreve seus projetos como "political-timingspecific " uma vez que não se relacionam apenas ao lugar, mas à vida pública afetada por práticas que existem e fazem sentido num momento político específico.

Neste contexto, o projeto Arte Útil surge como uma plataforma de longo prazo da artista, que procura também responder a um sistema de arte que absorveu o artista como um prestador de serviços, impondolhe ritmos de produtividade. Construído em colaboração com o Queens Museum, o Van Abbemuseum e o Grizedale Arts, o projeto procura identificar ações locais e iniciativas que lidem de modo inventivo com a autogestão e a transformação social, antes sob a responsabilidade do estado.

“Os projetos Arte Útil devem: propor novos usos para a arte na sociedade; usar o pensamento artístico para desafiar o campo em que opera; responder às urgências atuais; operar em uma escala 1: 1; substituir autores por iniciadores e espectadores por usuários; ter resultados práticos e benéficos para seus usuários; buscar a sustentabilidade e restabelecer a estética como um sistema de transformação" (ARTEÚTIL. online).

Portanto, Arte Útil está implicada na prática social, já que faz do uso e da utilidade do trabalho o seu sistema de interpretação da obra, mobilizando os diversos públicos em um sentido amplo.

Com a Escola de Arte Útil, Tania Bruguera transforma museus de todo o mundo em salas de aula e em espaços de debate e discussão, conferindo outros usos ao espaço expositivo, ativado pela artista para a realização de oficinas e seminários. Os mais de 200 casos mapeados pelo projeto ao longo dos últimos 10 anos e disponibilizados na plataforma digital https://www.arte-util.org/, demonstram que cada uma dessas iniciativas fomentam maneiras de se pensar processos, conteúdos e métodos de articulação social com real impacto sobre o mundo contemporâneo. 


\section{C1.10 Projeto (2007) Antoni Muntadas}

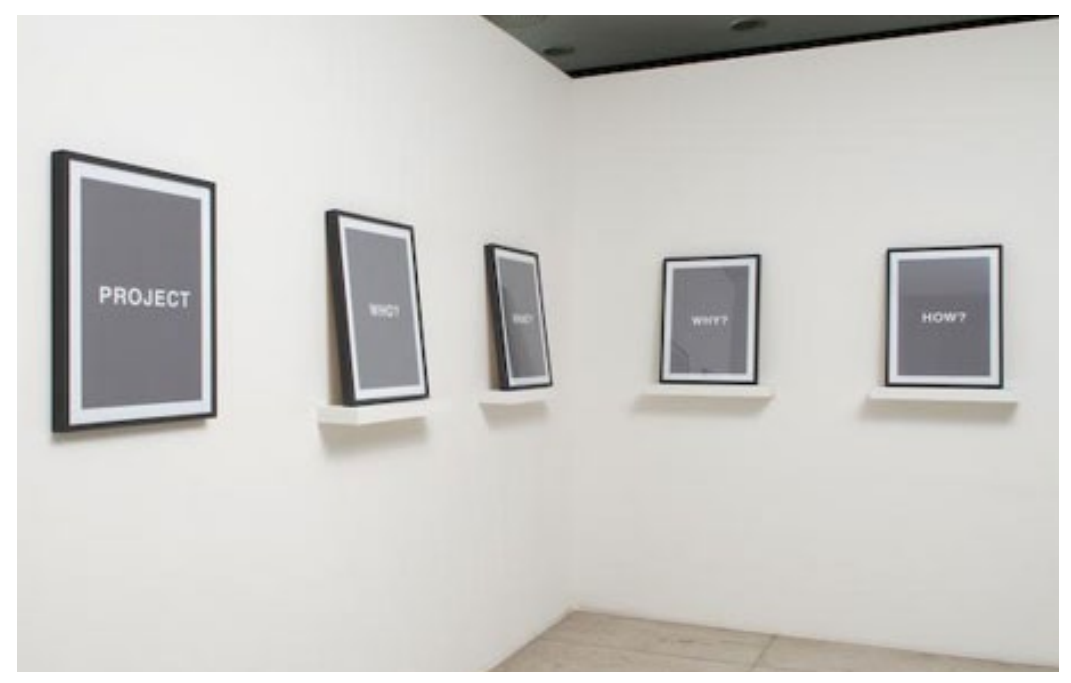

Projeto se estrutura como uma sequência de perguntas, um elemento disparador para o envolvimento do público, despertando atenção em relação ao seu próprio contexto, que pode ser o espaço do museu, a ser desafiado em sua suposta neutralidade, ou o sistema de ensino e seus protocolos, ou então o grande outdoor comercial que domina a visualidade dos espaços públicos nos quais se inserem.

Nas suas inúmeras facetas, Projeto gera novas versões, como traduções do mesmo trabalho. A cada nova versão, provoca um engajamento crítico do público com seu entorno, confrontado pelas perguntas: quem?; o que? por quê? como? onde? quando? Segundo Mundadas (2013, p. 32):

“... ‘Quem?', ‘O que?' e 'Por quê?' solicitam o desejo, o interesse, a necessidade e a responsabilidade em fazer. Além disso, 'Por quê?' define uma fase crucial do processo, a definição da pesquisa, e a reflexão sobre o que está nas origens do caminho. 'Como?' é o meio com que o trabalho será realizado, a identificação do mesmo terá lugar de uma forma orgânica e não mecânica, o projeto em si exigirá a forma. ‘Onde?', e 'Quando?" estão relacionados ao espaço e ao tempo, e nessas questões encontramos a noção de site-specific: um conceito ligado à história da arte a partir do final dos anos sessenta em que o trabalho é necessariamente considerado em relação ao espaço em que é feito."
Soma-se a essas questões uma última e decisiva condição, que expressa o desafio de se obter habilidosamente o máximo de rendimento a um custo controlado: 'quanto custa?'.

O título Projeto se explica, segundo Muntadas, pelo deslocamento das linguagens artísticas contemporâneas de sua materialidade para o processo empregado em seu desenvolvimento, tendo como consequência a "recusa do objeto como finalidade da produção" (MUNTADAS, 2013 , p.29). Com isso, etapas processuais passam a ser valorizadas como elementos indispensáveis do trabalho, uma vez que estes são o elemento chave para que se revele o encadeamento de decisões da experiência sensível do artista. É deste ponto que advém o título, Projeto, como na origem semântica do termo que indica o que se pretende criar no futuro.

Projeto é também uma estratégia pedagógica que Muntadas difunde em oficinas voltadas às práticas artísticas realizadas a partir da interpretação de contextos específicos. Assim, as traduções propostas pelo artista não dizem respeito apenas aos locais nos quais se inserem, mas também aos meios nos quais se infiltram, dando a ver a complexidade dos circuitos implicados em sua produção, representação e circulação, sejam eles veículos de disseminação, instituições ou molduras pedagógicas. 

2.

Distensões

da

prática

arquitetônica 



\title{
Procedimentos projetuais
}

Processos não excluem objetos. O contrário não é verdadeiro.

John Cage

Arquitetura é, e sempre foi, não apenas artesania, mas em primeiro lugar, uma gestão do espaço.

Yona Friedman

\begin{abstract}
A revisão dos princípios modernos processada pela arquitetura, a partir dos anos 1960, representou, por um lado, uma abertura da disciplina para debates externos e plurais, fato evidenciado pela intensa produção teórica e crítica do período associada à configuração de uma cultura arquitetônica ${ }^{77}$. Por outro, resultou numa prática e produção que, ao longo dos anos 1970 e, particularmente dos 1980, acabaram associadas a um fenômeno estilístico, inclinado a especulações formais extravagantes que, veiculadas e reproduzidas como imagem icônica de grandes empreendimentos, culminaram numa 'espetacularização do urbano', como precisou Otília Arantes (2002) ${ }^{78}$.
\end{abstract}

Alguns dos principais autores que se dedicaram ao exame da produção teórica desse período, como Kate Nesbitt, Diane Ghirardo, Reinhold Martins e K. Michael Hayes, entre outros, atestam a importância da crítica como a origem de uma cultura arquitetônica inserida num debate cultural ampliado. Hayes afirma que, após 1968, "a teoria da arquitetura praticamente subsumiu a cultura da arquitetura, pois o sentimento predominante nesses anos foi o de que a produção cultural, em seu sentido tradicional - especialmente o senso de cultura como algo ao qual simultaneamente se pertence e se possui, a cultura como alguma precipitação que satura de cima para baixo todo seu domínio, cultura como uma fronteira entre legitimidade e desestabilização - já não poderia surgir espontaneamente por uma questão de curso social, mas deveria ser constantemente construída, desconstruída e reconstruída através de procedimentos teóricos mais autoconscientes"(HAYES, 1998, p. X, tradução minha).

Em entrevista concedida em 2002 ao almanaque de filosofia e artes Rapsódia, Otília Arantes retoma um debate travado com Roberto Schwarz, por ocasião da defesa de sua livre docência, no qual defendera a impossibilidade de um "recolhimento estético" como autonomia para arquitetura, como intentava Schwarz. Ainda que a arquitetura moderna se colocasse de forma utópica, investida de "boas intenções democráticas”, seu entrelaçamento com o programa capitalista de 
Na busca por um distanciamento dos dogmas modernos, entre eles o dualismo forma e função, e a maneira como a forma, supostamente abstrata e simbolicamente neutra, seria capaz de implantar um projeto de desenvolvimento social isento de contaminação ideológica, a arquitetura desse período acabou, na prática, estabelecendo uma "continuidade fundamental entre arquitetos modernistas e pós-modernistas, pela reafirmação do poder da forma e, daí, da primazia do projeto, até a exclusão de outras estratégias para melhoria das cidades e das condições de vida”, conforme identifica Diane Ghirardo (2002, p. 26) em sua tentativa de registrar uma história concisa do período.

A discussão sobre a hiper performatividade dos edifícios, que se estende ao longo dos 1990 - intensificada pela implantação de grandes operações urbanas alavancadas por programas culturais como museus, salas de concerto, bibliotecas e teatros - atravessa o debate acerca das intersecções entre arte e arquitetura, tendo como caso mais emblemático o projeto de Frank Gehry para o museu Guggenheim de Bilbao (1991-1997), um paroxismo representado pela aliança de instituições culturais junto às esferas política e econômica na construção de uma identidade de cidade voltada a atrair investimentos, negócios e turismo, ou como coloca Hal Foster, "edifício quase abstrato como signo pop ou logotipo de mídia” (2012, p. 15).

Nesse contexto, de uma economia cultural global, Foster examina e qualifica como 'complexo arte-arquitetura' essa aproximação nem sempre equilibrada ou positiva entre arquitetos e artistas, resultando na construção de edifícios tão esculturais que dão a impressão de "que os artistas sentiram ter chegado atrasados para festa, como colaboradores depois do fato consumado" (FOSTER, 2012, p. $\mathrm{XI})$.

estandartização industrial resultou, segundo Arantes, em uma forma não figurativa e autônoma que se reproduziu por meio do emprego de princípios funcionalistas cujo programa de higienização e disciplina tratava de forjar o novo homem moderno. Assim, o formalismo engendrado pelo período moderno teria se desdobrado na "nova onda esteticista pós-moderna que celebra a diferença, a efemeridade e o espetáculo" como um "recrudescimento do fetichismo, porém noutro registro” (ARANTES, 2002, p. 235). Um registro no qual as relações sociais são reificadas e convertidas em imagem, e a arquitetura se realiza como simulação e cenário num processo de "culturalização do urbano" (ARANTES, 2002, p. 238) transformado em espaço espetacularizado. 
Foster também constata que, num dado momento, a arte torna-se o principal ponto de partida para informar o trabalho de diversos escritórios de arquitetura que, em substituição ao engajamento com a teoria ${ }^{79}$, assimilam discursos e estratégias da arte como condição para uma produção de vanguarda, como é o caso de Diller, Scofidio e Renfro, que absorvem experiências da arte conceitual incorporando a performance e pautas feministas em alguns de seus primeiros trabalhos nos anos 1980. Ou seja, essa aproximação com a arte se dá de forma plural, e não necessariamente culmina com a criação da imagem icônica que modela o espaço da economia cultural, podendo se abrir para diferentes perspectivas a partir dessa contaminação, inclusive para questionamentos sobre a potência prescritiva da arquitetura e sua materialização formal.

Em outros termos, o historiador da arquitetura Reinhold Martin, em sua revisão sobre o pós-modernismo na arquitetura, complementa:

Isso é em parte o que quero dizer ao insistir que o pós-modernismo não é um estilo, mas uma formação discursiva: uma maneira de falar sobre o mundo e um modo de agir nele que tornam certas afirmações possíveis excluindo outras, tornando-as impensáveis. Entre estes últimos está a utopia não no sentido de um mundo ideal, mas no sentido de mudança sistêmica. (MARTIN, 2012, p. 14, tradução minha $)^{80}$.

A afirmação de que o pós-modernismo não pode ser reduzido a um estilo e, como tal, não deveria ser associado apenas a uma produção caricatural e formalista, destituída

Basta pensar em arquitetos como Aldo Rossi, Robert Venturi e Denise Scott Brown, Peter Eisenman e Bernard Tschumi, e como sua produção teórica e projetual estabelece correspondências e suscita indagações e provocações que informam tanto uma 'divagação teórica' quanto o conjunto de procedimentos e estratégias para 'configurar o construído’, como nos apresenta Rafael Moneo em Inquietação teórica e estratégia projetual na obra de oito arquitetos contemporâneos (2008).

$80 \quad$ No original: "That is partly what I mean by insisting that postmodernism is not a style but a discursive formation: a way of speaking about the world and a way of acting in it that makes certain statements possible while excluding others by making them, in effect, unthinkable. Among the latter is Utopia not in the sense of an ideal world, but in the sense of systemic change". 
de um compromisso social ${ }^{81}$, coloca luz sobre a importância do período revisitado por Martin, em Utopia's Ghost. Architecture and Postmodernism Again (2010), livro em que analisa a maneira pela qual, neste período, se configura uma "formação discursiva arquitetônica" (MARTIN, 2010, p. $\mathrm{XXI)}$.

Trata-se, portanto, de se pensar os desdobramentos desse debate e seu impacto não somente sobre a produção teórica que o sucede, mas também sobre sua influência na reorganização da prática no contexto de uma condição pósmoderna, com uma investigação sobre como a arquitetura passa a incorporar novos procedimentos e a repensar seus modos e agir, como afirma Martin. Se a continuidade entre arquitetos modernistas e pós-modernistas se deu pela afirmação da forma, e pela "primazia do projeto”, como afirma Ghirardo, uma transição foi semeada nesse período, principalmente no que diz respeito à relativização da importância do projeto, ou de uma alteração de sua noção strictu sensu, com efeito de ampliação de seus desígnios na prática recente.

Essa alteração, ou ampliação da prática projetual, decorre principalmente da absorção da formação discursiva pela arquitetura, como um elemento que atravessa diversas etapas e camadas envolvidas na sua produção, desde a sua formulação até sua execução, o que estabelece uma ruptura com o padrão de que a forma pode ser a única geradora de significado. O que implica também um alargamento dos limites disciplinares e uma aproximação cada vez mais estreita com procedimentos empregados nas

No Brasil, o debate acerca do pós-modernismo foi circunscrito a uma questão formal ou a um modismo passageiro, permanecendo, ao longo dos anos 1980, restrito à algumas experimentações que emulavam formas importadas, ou buscavam conectar-se à história colonial. Segundo a historiadora da arquitetura Ana Luiza Nobre, na apresentação do livro manifesto de Paolo Portoghesi, Depois da Arquitetura Moderna (1980), o pós-modernismo entre nós sofreu de uma "disseminação afobada" e "teve como corolário uma miscelânea de interpretações errôneas e risíveis". Ainda segundo a autora, o modernismo brasileiro passava, então, no começo dos anos 1980, por uma incipiente revisão crítica, e diante desse contexto teria "se afigurado para alguns como uma chave para a saída do difícil impasse vivenciado pela arquitetura brasileira; de um lado, tomada de reverência pela obra ímpar de Lucio Costa e Oscar Niemeyer, de outro, movida pelo componente de rebeldia próprio da geração de arquitetos formados justamente no período mais negro da ditadura militar” (NOBRE, 2001, p. X). 
práticas artísticas no mesmo período, alterando o sentido consolidado da produção projetual e sua postura reativa e responsiva entre encomenda e programas preestabelecidos.

Basta pensar nos projetos dos franceses Lacaton e Vassal, e no modo como se posicionam para reverter as lógicas econômicas aplicadas à produção e à implantação de novas construções. A dupla, em parceria com o arquiteto Frédéric Druot, sistematizou no manifesto PLUS sua máxima antidemolição como uma atitude de precisão, delicadeza, amabilidade e atenção às pessoas, usos, edifícios, árvores, superfícies de asfalto e grama, para o que existe" (DRUOT; LACATON; VASSAL, 2007, p. 29), de forma a causar o mínimo de inconveniência.

Sintetizando: "É uma questão de nunca demolir, subtrair ou substituir coisas, sempre somar, transformar e reutilizá-las!" (DRUOT; LACATON; VASSAL, 2007, p. 29, tradução minha ${ }^{82}$.

Dessa forma, apresentaram uma alternativa ao consumo dispensável de recursos, energia e espaço, assegurando a reutilização de conjuntos habitacionais modernistas em cidades como Paris (Tour Bois le Prêtre - 2011), Saint Nazare (La Chesnaie - 2014 e 2016) e Bordeaux (Cité du Grand Parc - 2016). Mediante adequações de infraestrutura, e transformações para novos usos, ampliaram a área de cada unidade habitacional e melhoraram as condições de iluminação e ventilação a custos comprovadamente inferiores ao da demolição para a construção de novas unidades. Com isso, garantiram a permanência dos edifícios modernos, símbolos da política de habitação social francesa do pós-guerra. Agindo sobre as potencialidades destes edifícios e enfrentando problemas diagnosticados por meio de um levantamento atento às novas necessidades após anos de uso, buscaram reverter estigmas associados a esses edifícios para favorecer o reaproveitamento "dessa herança cultural que tinha que ser fiel à sua modernidade” (HUBER, 2016, online, tradução minha) ${ }^{83}$, adotando propostas com real impacto na qualidade de vida de seus moradores.

Mas é em um projeto anterior, numa pequena praça

No original: "It's a matter of never demolishing, subtracting or replacing things, but of always adding, transforming and utilizing them". No original: "[...] this cultural heritage had to be true to its modernity". 
em Bordeaux, que a dupla tensiona o papel prescritivo e formal da arquitetura de maneira mais radical. Convidados a propor uma requalificação de embelezamento para a praça Lèon Aucoc (1996) <imagem C2.1 p.144>, encomendada pelo município, os arquitetos decidem se abster de um desenho que propusesse uma modernização dos materiais existentes e a implantação de novos equipamentos urbanos para manter a praça exatamente como estava. Ao reconhecerem a qualidade inerente ao espaço desta típica praça francesa, com bancos e luminárias de desenho despretensioso, piso de cascalho e área para se jogar pétanque, optam por ressaltar as características legitimadas pelo uso dos moradores de seu entorno, adotando uma estratégia de reversão da demanda oficial.

Como resposta, após quatro meses frequentando a praça semanalmente, a encomenda foi colocada em xeque pelo desenvolvimento de uma argumentação baseada no levantamento de dados e na mobilização de usuários, de forma a se fazer reconhecer o valor de uso existente, colocado em risco pelas modificações e descaracterizações financiadas pelo investimento público. Por meio dessa ação incomum, em um meio associado à expressão do objeto arquitetônico e sua autoria, os arquitetos sugerem a reversão do investimento para a simples manutenção do local, com reposição do cascalho, limpeza frequente e cuidado com a vegetação.

O que se segue é uma negociação entre funcionários públicos, que a princípio rejeitam a proposta por verem seu desejo de intervenção física no espaço frustrado, e o posicionamento dos arquitetos que, ao confrontarem a demanda, expuseram o interesse subjacente à proposta da nova gestão municipal, interessada em adquirir um projeto de imagem ao qual se vincular. O diagnóstico de que a qualidade já existia e a beleza encontrava-se na simplicidade, consequência da vida cotidiana pré-existente, estabelece uma intervenção na narrativa subjacente à encomenda, na qual a melhoria do espaço público se resumia a um projeto estetizante.

Anne Lacaton afirma, ao ser questionada sobre o projeto da praça Lèon Aucoc, em uma entrevista de 2003, que "o trabalho de um arquiteto não é apenas construir, a primeira coisa a fazer é pensar” (LACATON, 2003, p.117, 
tradução minha) ${ }^{84}$ e, com isso, avaliar a real necessidade de se construir, ou não. Portanto, essa retenção não significa uma negação ou ataque à arquitetura, mas uma abordagem diferente sobre seu papel. Ao flertar com a dúvida e negar a necessidade do objeto construído, o projeto afirmase como ação crítica, na qual a negativa revela a lógica administrativa envolvida para endereçar por meio deste processo questões fundamentais sobre a esfera pública, e a quem cabe as decisões que determinam o futuro das cidades.

Lacaton e Vassal produzem uma investigação autocrítica que revela a disposição da disciplina para atuar em contato próximo a contextos específicos, como um agente organizacional em um sistema no qual a construção não é o único fim e a forma resultante não é o único contentor do significado.

Há, portanto, a possibilidade de se estabelecer uma conexão entre o projeto de embelezamento não realizado na praça em Bordeaux e a 'retirada perceptiva' por parte da arte conceitual, empreendida ao longo dos anos 1960. Nessa época, recorrendo a um rebaixamento da predominância da visualidade, a arte sublinha a experiência mental em trabalhos nos quais "a definição de estética se torna, por um lado, uma questão de convenção linguística e, por outro, a função de um contrato legal e de manifestação institucional - discurso de poder e não de gosto” (BUCHLOH, 1990, p.118). Assim, diante do reconhecimento da impossibilidade de se manter a autonomia e autossuficiência do objeto artístico moderno, o trabalho de arte é deslocado para uma prática crítica em que as instâncias administrativas e de validação das instituições nas quais se inscreve são tensionadas em seus procedimentos e seus mecanismos ideológicos.

Jean Philippe Vassal, que se diz mais interessado no ponto de vista de artistas contemporâneos sobre a arquitetura do que no de seus colegas arquitetos-artistas, acredita que a arte tem oferecido perspectivas mais relevantes de abordagem sobre as relações entre um espaço comum e outro interpessoal. Chama atenção a maneira

No original: "It is not about refusing to do something, but we consider that the work of an architect is not only to build, the first think to do is to think, and only after you are able to say whether you should build or not. Very often you have to build, but sometimes not." 
como sua fala corrobora a noção de arquitetura como um sistema organizacional:

Estou interessado na ideia de tentar definir alguns sistemas que possam proporcionar liberdade para seus usuários e para as pessoas em geral. Este é o tema principal para mim. Porque muitas vezes acho que o planejamento urbano ou a arquitetura está fechando espaço, fechando possibilidades e, assim, limitando a liberdade. Então, em algumas ocasiões, eu posso encontrar coisas interessantes em alguns trabalhos de artistas contemporâneos relacionados com a questão do espaço de todos, e do espaço de cada um. (VASSAL, 2016, online, tradução minha) ${ }^{85}$.

Nesse sentido, podemos compreender um desvio estratégico adotado por Lacaton e Vassal como procedimento semelhante à negação dos critérios visuais tradicionais utilizados pela arte conceitual, anos antes. Ao se recusarem a modificar desnecessariamente o espaço da praça, instauram uma prática crítica de caráter discursivo que redireciona o campo de ação do ato de projetar e de construir para o campo das negociações e justificativas em torno do não projeto.

Reforçam, dessa forma, o caráter eminentemente político e de crítica institucional dessa ação. Há nesse gesto, assim como na arte conceitual, um claro esforço de desvio da lógica positivista vigente nas relações de produção e consumo, seja no sistema da arte, na forma arquitetônica ou no espaço público.

No original: "I'm interested in the idea of trying to define some systems which may provide freedom for its users and for people in general. This is the main topic for me. Because very often I think that urban planning or architecture is closing space, closing possibilities and thus limiting freedom. So, in some occasions, I can find interesting things in some works by contemporary artists related with the question of a space of everybody, space for each”. 


\section{Programa, indeterminação e uso}

A inquietação presente na declaração de Jean-Philippe Vassal, sobre deixar aberturas para o imprevisto e para a liberdade em contraposição à tendência da arquitetura e do urbanismo em interditar o espaço, pode ser aproximada do trabalho de John Cage - músico e artista paradigmático para arte conceitual, o que remonta à sua experiência como regente do primeiro happening ${ }^{86}$ - e seu interesse em definir sistemas abertos que pudessem incorporar o público e romper estruturas rígidas de composição musical.

Cage questionava a estrutura tradicionalmente fechada da música ocidental, ordenada por notas e compassos organizados como uma construção autoral, para propor como alternativa a absorção dos ruídos e dos imprevistos da vida para dentro da peça musical. Como em 4'33" (1952), na qual o momento que antecede o início da interpretação dos músicos é encenado, mas o que se segue são 4 minutos e 33 segundos de silêncio. Essa peça silenciosa interpela o público e desperta sua atenção para os diversos sons e ruídos do ambiente que, em sua "expressividade não-intencional", e únicos a cada nova execução, proporcionam uma apreciação dos "prazeres da sociabilidade" presentes na sala de concerto (CAGE, 1974, p. 334). Daí sua manifesta predileção por processos em lugar de objetos, justamente porque processos, como sistemas abertos, podem desencadear a produção de objetos, enquanto o inverso jamais será possível. Em outros termos, nos coloca Cage, "uma variedade de disciplinas vai continuar a ser usada a fim de tornar a mente receptiva para eventos que estão além de seu controle" (CAGE, 1974, p. 334).

Acontecimento ocorrido no refeitório da lendária escola de arte Black Mountain College, em 1952, onde John Cage, juntamente com o bailarino e coreógrafo Merce Cunningham, o artista Robert Rauschenberg e o pianista Dave Tudor, realiza uma série de performances num intervalo de tempo coreografado, mas sem relação narrativa ou causal entre si. O evento sem título, mas agora conhecido como peça teatral n.1, embora presenciado por um pequeno público, conquistou notoriedade e reverberou vivamente nas décadas seguintes. 
A tentativa de garantir um estado de latência ao espaço, de forma a mantê-lo indeterminado e aberto ao acaso e às apropriações inesperadas, contestando a propensão de controle exercida pelo projeto, não é uma novidade para a arquitetura. O projeto como antecipação de uma ação futura, consolidado pela disciplina como o conjunto de informações e instruções gráficas que agenciam os diversos subsistemas necessários para a realização da construção, tende à determinação de espaços fechados, e enfatiza o reconhecimento da autoria.

Pensar processos, portanto, recai diretamente sobre uma reconfiguração das "metodologias de projeto", um enfrentamento tão desafiador quanto presente na arquitetura contemporânea, que tem expandido suas abordagens e seus modos de atuação. Enfoques de projeto que valorizam etapas processuais e procuram elaborar sistemas abertos incidem diretamente sobre a máxima funcionalista moderna como princípio que orienta a forma, desdobrando-se em especulações sobre abordagens ao programa de necessidades. Um procedimento projetual que parece renegar a orientação do programa arquitetônico prescritivo para questioná-lo no sentido de um "desenvolvimento crítico da ideia do programa, impulsionado por várias intervenções na concepção e na prática do projeto” (VIDLER, 2003, p. 60).

Reconfigurado pelo reconhecimento de condições locais e situações específicas, orientado por dúvidas e não por certezas, em sintonia com demandas éticas e políticas, o programa, segundo Vidler, converte-se no "local específico"87, uma referência próxima ao debate desencadeado no campo artístico anos antes, a partir de práticas site-specific e sua relação contextual, que ultrapassa a interpretação fenomenológica de um lugar para envolver condições culturais e sociais. Esse mesmo caminho, trilhado de maneira semelhante pela arquitetura, favorece, segundo o autor, o surgimento de uma "tecnologia do cotidiano" (VIDLER, 2003, p. 59).

Tal fenômeno transparece nos testemunhos de Anne Lacaton e sua defesa de uma intervenção sobre o programa como uma premissa a ser questionada de forma a garantir uso, sentido e custo nos contextos em que se inserem. Com

No original Vidler refere-se a "specific sites, which are considered as programs themselves." 
base nesse enunciado, Lacaton e Vassal atacam tanto a obsessão pela forma quanto o desejo de resolver problemas, assumindo desvios em relação ao sentido enrijecido do projeto como coordenação de informações técnicas para tomada decisões, ou como uma consequência entre o programa de necessidades e a função como indutores da forma. Ou seja, esse posicionamento, que não se pauta por uma premissa funcional determinista, pode garantir um resultado que não é autônomo formalmente, mas uma forma impregnada de sentido, uma vez que surge pela legitimação de uma prática de desenho vinculada aos contextos nos quais se atua.

Portanto, se praticamente invisível, ou imperceptível, o projeto da Praça León Aucóc é ainda hoje um exemplo representativo da maneira como Lacaton e Vassal procuram enfrentar suas encomendas - algo flagrante nas fotos do projeto <imagem C2.1 p.144> -, que não dá a ver a complexidade do encadeamento de ações necessárias para se comprovar que não fazer nada, naquele caso, era fazer muito. Com essa ação sutil, legitimam uma prática que se dispõe a clarear e organizar problemas, e não a buscar respostas ou soluções imediatas.

Nas palavras de Anne Lacaton (apud MARTINS, 2009, online): "arquitetos reagem ao invés de iniciar, respondem ao invés de agir, contestam ao invés de formular”.

Esse movimento de aderência ao contexto resulta, portanto, numa extensão de etapas processuais que se desdobram em coleta e análise de dados, mediação e diálogo entre usuários e instâncias governamentais, atenção e interferência em políticas locais e reconhecimento de instâncias culturais, culminando numa reformulação dos parâmetros que orientam o projeto tendo em vista um sentido ampliado de articulação social. Em alguns casos, as etapas processuais se desdobram em projetos paralelos e transferem o sentido do projeto arquitetônico para uma intervenção em camadas discursivas, uma vez que reconhecem e visibilizam modos de vida que demandam outras abordagens ou que prescindem de projetos que resultem em edificações.

Assim, essa interrupção do fluxo entre a encomenda e a resposta - como se se tratasse de uma sequência linear a reafirmar a máxima "a forma segue a função" -, expande o domínio do programa arquitetônico.

Sobre essa máxima, na conclusão de Teoria e projeto na primeira era da máquina (1960), o historiador inglês 
Reyner Banham relativiza o impacto da sentença como fator determinante para a arquitetura moderna e afirma: "Pode ser que o funcionalismo, como credo ou programa, possua uma certa nobreza austera; simbolicamente, porém, está assolado pela pobreza” (BANHAM,2013, p. 500). Com isso propõe uma revisão do funcionalismo como "palavra falaciosa" que serviu para rotular o Estilo Internacional e acabou por achatar possibilidades de análise que não fossem tão dependentes de um viés racionalista.

Para Banham, "a emoção havia representado um papel bem maior que a lógica na criação do estilo” (2013, p. 501) e formas simbólicas sempre estiveram presentes na produção moderna. Da mesma forma, suas análises críticas da arquitetura, pós anos 1960, para a revista Architecture Review, o levam a sopesar a relevância da máxima, equalizando-a:

"Funcionalismo com letra maiúscula está morto, vida longa ao funcionalismo com " $\mathrm{f}$ ” minúsculo baseado na ciência real” (BANHAM apud VIDLER, 2003, p.64).

Portanto, não se trata de associar o funcionalismo à revogação de valores simbólicos, assim como a adesão ao contexto não significa o cancelamento de premissas funcionais, mas sim uma busca por conferir maior valor de uso para a inscrição social de um projeto, o que passa por um questionamento a respeito do programa de necessidades como é determinado, em que grau é determinado e quem o determina.

Não é à toa que um arquiteto como Rem Koolhaas tenha atacado também essa questão - ainda que por um viés de ambígua adesão ao mercado ${ }^{88}$. Para Koolhaas, o programa é mais difuso e menos relacionado com a obra a ser construída, questões que enunciou em $S, M, L, X L$ (1995): “um máximo de programa, um mínimo de arquitetura”, e “onde não há nada, tudo é possível; onde há arquitetura, nada mais é possível” (apud MONEO 2008, p. 288).

88 Nesse sentido o historiador de arquitetura argentino Adrián Gorelik é preciso: "talvez ninguém tenha criticado de modo tão inteligente como Koolhaas a cegueira do urbanismo, sua mitificação heroica e progressista. Sempre irônico, sempre espirituoso, ele decidiu jogar no papel ambíguo de quem conhece como ninguém as regras da cidade e da arquitetura do mundo global contemporâneo, o que serve tanto para a crítica afiada de seus escritos, como para oferecer as respostas mais adequadas em suas obras e, com elas, criticar os arquitetos que não as entende ou aceita” (2006, p29. tradução minha). 
Agir de diversos modos sobre o programa é estratégia que ressurge como procedimento recorrente, adotado e defendido por outros grupos em atuação hoje, em escala global.

\section{Do programa ao lugar específico}

Um caso exemplar do emprego desta estratégia é a atuação dos arquitetos japoneses a frente do Atelier Bow-Wow ${ }^{89}$, que são conhecidos por sua maneira de pensar intervenções a partir do reconhecimento de condições preexistentes - o que não significa apenas a decodificação das informações do entorno físico, mas uma operação cuidadosa de entendimento das condições de vida e das relações cotidianas entre as pessoas envolvidas.

As pesquisas, que precedem qualquer intervenção, possuem um caráter etnográfico de interpretação cultural como forma de envolver as comunidades com as quais trabalham nos diversos momentos de produção, desde a elaboração do programa de necessidades, passando por etapas preliminares de discussão acerca das inúmeras soluções possíveis, até a ponderação sobre alternativas que não envolvam construção ou intervenção física no espaço, mas gestão, reordenação e reuso do que já existe.

A natureza investigativa por trás do trabalho do BowWow estava declarada desde o início de suas atividades, quando mapearam soluções da arquitetura informal e não planejada que emergem do enfrentamento das condições de vida nas cidades japonesas hiperadensadas. Esses registros foram compilados em dois livros: Made in Tokio (2001) e Pet Architecture $(2002)^{90}$.

Escritório formado em 1992 por Yoshiharu Tsukamoto e Momoyo Kaijima, ao qual posteriormente se agrega Yoichi Tamai. O nome utiliza a grafia francesa para a palavra ateliê, e Bow-Wow que poderia ser traduzido para "au-au”, ou seja, a maneira infantil de se referir aos cachorros pelo som de seu latido, o que no Japão altera sua grafia para Atelier Wan-Wan, "porque cães japoneses latem wan”, de acordo com Kajima (KAJIMA apud GREENE, 2008, p. 51).

Pode-se dizer que ambos se inscrevem numa linhagem de investigações sobre a cidade real e comum. Não é coincidência, portanto, que Momoyo Kaijima cite o já referido Aprendendo em Las Vegas (1966), de Denise Scott Brown, Venturi e Izenour, como fonte de inspiração para tentar compreender o fenômeno da rápida urbanização que ela vivenciou ao longo dos anos 1980, no Japão. Além desse, ela menciona outros livros que contribuíram para sua formação por apresentarem novas perspectivas para a teoria da arquitetura e do urbanismo. São eles: Architecture 
Em Pet Architecture, pequenos edifícios construídos nas nesgas de terrenos residuais decorrentes da subdivisão de lotes maiores ${ }^{91}$ - de esquinas obliquas a micro lotes esdrúxulos -, são documentados, desenhados, analisados e somados aos relatos de seus habitantes, resultando num conjunto de soluções inusitadas, como uma espécie de tratado arquitetônico para o enfrentamento de problemas distintos, tais como: ventilação, acessos, escadas e outros recursos. Segundo os arquitetos, essas improvisações podem não ser levadas a sério por muitos, mas informam sua maneira inventiva de projetar em condições extremas na cidade de Tóquio, fazendo uso de reinterpretações das soluções documentadas nesse vocabulário informal.

Com esse olhar analítico e sensível ao cotidiano e ao ordinário, inclusive ao que pode ser considerado duvidoso - lembrando que a assertiva "o espaço urbano através da arquitetura que os arquitetos gostariam de esquecer" é o subtítulo provocativo de Made in Tokio -, o Ateliê Bow-Wow reconhece fricções entre instâncias de comportamento que se cruzam e que demandam interpretação para a elaboração de seus projetos: o comportamento humano e o comportamento dos fenômenos naturais nos, e em torno dos, edifícios e do espaço público.

Daí deriva o neologismo utilizado como título de um livro sobre a produção do escritório, Behaviorology (2010), ou poderíamos dizer comportamentologia, concepção que pode ser sintetizada por uma imagem apresentada por Yoshiharu Tsukamoto durante conferência no Canadian Centre for Architecture (CCA $)^{92}$. Vemos nessa imagem um

Without Architects , de Bernard Rudofsky, A arquitetura da cidade (1966), de Aldo Rossi, e Nova Iorque delirante, de Rem Koollhaas (1978) .

91 Ao longo do tempo, as propriedades que possuíam $250 \mathrm{~m}^{2}$ foram fracionadas e, hoje, os lotes possuem em média $80 \mathrm{~m}^{2}$, resultado de dois fatores combinados: a explosão da bolha econômica do Japão, na década de 1980, que levou a uma valorização da terra; e as altas cargas tributárias, que impeliram herdeiros de grandes terrenos a subdividir e vender lotes menores como única alternativa para quitarem os impostos e permanecer com parte dos imóveis. Isso afetou a tipologia dos bairros residenciais onde predominam casas que, de acordo com sua implantação, permitem identificar o período em que foram construídas, culminando com as soluções atuais, em lotes estreitos e de alta densidade - soluções de baixa qualidade arquitetônica, determinadas principalmente pela especulação imobiliária.

92 O vídeo documenta a conferência Architecture Behaviorology. Disponível em: https://www.youtube.com/watch?v=-AJ9wWZIop0 . Acesso em: 9 jan. 2020. 
grupo de pessoas sentadas, enfileiradas, numa calçada; todas acomodadas de modo a se recostarem contra uma mureta na cidade de Copenhague. Ao fim de um dia de sol, a pedra com a qual a mureta fora construída havia armazenado calor suficiente para funcionar como um aquecedor natural que todos queriam aproveitar para desfrutar dos últimos momentos do dia.

Essa confluência de comportamentos pode ser melhor analisada no projeto de longo prazo desenvolvido pelo Bow-Wow com uma comunidade de pescadores afetados pelo terremoto de Tōhoku, seguido do tsunami de 2011, em Momonoura.

O caráter emergencial para que se mitigassem os efeitos da catástrofe e fosse dado início à reconstrução da vila não alterou o modo de aproximação da dupla de arquitetos, que, com sua experiência para reconhecer o repertório cultural e construtivo vernacular, passou a coletar depoimentos dos moradores mais velhos, e realizou um mapeamento da comunidade, como forma de rememorar e enaltecer o modo de vida local de seus habitantes. Com isso, entre outras medidas, foi possível restabelecer sua conexão com as montanhas e o extrativismo de árvores frutíferas, que durante muitos anos abasteceu aquela comunidade e era um recurso indispensável para enfrentar o período de reconstrução.

Tsukamoto ressalta que ler a comunidade, escrever e aprender com processos mais próximos da etnografia do que dos estudos urbanos significa, para ele, praticar arquitetura. Uma elaboração que suplanta a obrigação de fabricação que dominou todo o pensamento do século $\mathrm{XX}$, avançando também sobre esfera da construção como produção industrializada. No caso de Momonoura, soluções rápidas poderiam desencadear, no longo prazo, consequências que se mostrariam desastrosas por não imaginarem nem incorporarem alternativas ao estilo de vida urbano contemporâneo tomado como modelo de sociedade consolidado ${ }^{93}$.

Não se trata, segundo o arquiteto japonês, de 
retroceder as intervenções a um estágio artesanal de produção, mas reconhecer que, nessa vila, há um “hibridismo fantástico entre relações sociais etnográficas e industriais” (TSUKAMOTO, 2018, depoimento em vídeo ${ }^{94}$ ).

Se tomarmos uma definição contemporânea da etnografia para o campo da antropologia, não como método ou exploração do exotismo, mas como estranhamento e pré-disposição para a pesquisa empírica e imprevisível de modo a questionar certezas e verdades estabelecidas rumo a uma compreensão do mundo em que vivemos (PEIRANO, 2014), é possível iluminar o que a "etnografia arquitetônica" do Bow-Wow pretende implementar. Kaijima valoriza a pesquisa empírica como modo de se aproximar de pessoas e comunidades, agenciando modos de representação que aproximam o projeto de seus destinatários e dos diversos técnicos e colaboradores, o que inclui os futuros usuários. Segundo a arquiteta:

Uma das características da arquitetura é que ela possui seus próprios meios internos de avaliação crítica que orientam o projeto em todas as etapas de seu desenvolvimento. Trabalhando continuamente em escalas que variam de 1:1 a 1:1000, o arquiteto se move fluidamente entre diferentes dimensões, entre parte e todo, entre o empírico e a abstração. É essa qualidade de autonomia do projeto que pode ser combinada à etnografia para compor uma etnografia arquitetônica. (KAIJIMA, 2018, online, tradução minha).

Essa virada antropológica em muito se assemelha ao diagnóstico de uma virada cultural da arte elaborado pelo crítico Hal Foster no texto O artista como etnógrafo (1996), sendo possível estabelecer um paralelo com a tendência de mapeamentos sociológicos e antropológicos pela arte de viés site-specific (FOSTER, 2017, p. 174), posto que a noção de lugar deixa de ser associada às características físicas para abarcar grupos de pessoas, comunidades e as pautas

Depoimento extraído do vídeo que integra o projeto do CCA Islands and Villages. A documentary series on the posturban phenomenon in rural Japan (2018) 9':18”. Disponível em: https://www.cca.qc.ca/en/articles/issues/26/what-about-theprovinces/56455/islands-and-villages . Acesso em: 10 jan. 2019. 
multiculturais.

Foster cita inúmeros exemplos dessa orientação gradual da arte para a etnografia, desde os mapeamentos fotográficos de Ruscha <imagem C1.2, p.71>, em Los Angeles, ou em estradas, como em Vinte e seis postos de gasolina (1963), até as enquetes realizadas por Haans Hacke como crítica institucional, ou ainda, os trabalhos de matriz documental que endereçam questões sociopolíticas globais, como o trabalho de Alan Sekula ou Martha Roesler <imagem C1.3 p.72>.

No entanto, toda essa diligência artística teria, segundo o crítico, resultado em conexões discursivas que "borram as antigas memórias disciplinares", e "tornam a arte contemporânea perigosamente política” à medida em que a perda de distanciamento crítico com a realidade representaria um risco de "superidentificação com o outro" (FOSTER, 2017, p. 185).

Para a curadora de arquitetura Kayoko Ota ${ }^{95}$, no ensaio The Posturban Phenomenon (2018), essa virada etnográfica é positiva, refletindo mais sobre o Japão contemporâneo e as possibilidades de contribuição da arquitetura para a transformação social do que o programa de recuperação emergencial transparecia.

$\mathrm{Na}$ perspectiva de Ota, grandes arquitetos japoneses como Toyo Ito e Kazuyo Sejima estão olhando para fora dos limites urbanos, uma vez que fenômenos como o decréscimo populacional japonês, o encolhimento das grandes cidades e o empobrecimento de pequenas comunidades rurais e pesqueiras, aliado a uma possível mudança de valores das novas gerações, que não encaram os grandes centros urbanos como única alternativa de vida, fazem com que esses lugares abram novas frentes para reinvenção da prática, oferecendo:

[...] condições não encontradas nas cidades [...]. Isso é um "ganho" para arquitetos e para o intercâmbio entre arquitetos e seus colegas. Uma hipótese do

Kayoko Ota é curadora de arquitetura baseada em Tóquio, onde fundou a PLAT, uma plataforma para aprimorar o pensamento arquitetônico em projetos culturais e educacionais socialmente engajados. Ota contribui durante 10 anos com o AMO, o estúdio de pesquisa, gestão de marcas e publicação do escritório OMA, e foi curadora do pavilhão japonês na Bienal de Arquitetura de Veneza em 2014. 
motivo é que, uma vez que a população de uma área diminuiu até certo ponto, é criado um espaço para medidas e experimentação não convencionais, além dos marcos administrativos e das lógicas capitalistas dos centros urbanos. Os arquitetos que chegam a esses lugares podem, dentro desse contexto diferente, tentar o que havia sido limitado ou negado anteriormente na cidade e ampliar seu repertório de práticas - se não na forma de projeto tradicional de construção, talvez por meio de um pensamento arquitetônico ou de uma pesquisa ampliada (OTA, 2018, online, tradução minha) ${ }^{96}$.

Ao instigar projetos que, em suas palavras, não são "imediatamente arquitetônicos", o Bow-Wow aproxima pesquisa e prática como elementos intrinsecamente conectados para a formulação de problemas, etapa tão valorizada quanto a elaboração de soluções - construídas ou não.

O processo em Momonoura resultou, afinal, na construção de uma série de pequenos edifícios espalhados pela vila <imagem C2.2 p.145>, mas os relatos sobre o projeto se baseiam no processo e no conjunto de ações estratégicas, mais do que nas construções. O ponto central para o conjunto das intervenções foi a criação de uma escola de pescadores, iniciativa fundada para propiciar o livre intercâmbio de conhecimento entre técnicos de diversas áreas, estudantes de arquitetura e as tradições locais voltadas a criação propiciando uma vitalidade para o programa de apoio à recuperação do povoado. O envolvimento dos arquitetos extrapola, portanto, o projeto e a construção do edifício da escola para pensá-la, e nela atuarem regularmente, de modo a fazerem desse espaço um lugar de irradiação e agenciamento social necessário para a

No original: "[...] they offer conditions not found in the cities where they are based. That's a "gain" for architects, to answer my earlier question about the exchange between architects and their counterparts. One hypothesis for why it is that once the population of an area has thinned to a certain extent, a space is created for unconventional measures and experimentation, beyond the administrative frameworks and capitalist logics of urban centers. Architects who arrive in these places may, within this different context, attempt what had previously been limited or denied in the city and extend their repertoire of practice-if not in the form of traditional building design, then perhaps through architectural thinking or expanded research". 
recuperação da vila no longo prazo.

Uma experiência semelhante é o projeto Broadway Estate Community Garden (2005) ${ }^{97}$ <imagem C2.3 p.146> do escritório inglês Muf architecture/art, em Tilbury, um distrito próximo a Londres, no estuário do rio Tâmisa. Trata-se de uma região voltada para a atividade portuária e repleta de armazéns de cargas. O município, inserido num programa de desenvolvimento estratégico da região para fomentar atividades econômicas e comunidades sustentáveis, encomendou ao Muf um projeto de parque para uma área descampada entre conjuntos habitacionais, tida como área abandonada e sem uso.

Após uma primeira investigação da área, as arquitetas Liza Fior e Mel Dodd constataram que a área na qual deveriam intervir não estava abandonada ou vazia, dado que sua grande extensão gramada era utilizada para o pasto de cavalos e como picadeiro para prática de equitação. Essa constatação fez com que o Muf reorientasse sua abordagem ao projeto para aprofundar a pesquisa e o envolvimento com o lugar ${ }^{98}$, evidenciando aspectos importantes da cultura local que foram omitidos do relatório e dos documentos oficiais sobre a implantação do projeto. Dessa forma, procuraram reverter o programa oficial mapeando redes de moradores dispostos a contribuir com sua revisão, e passaram a mediar o processo no sentido de agregar e mobilizar as demandas dos diversos grupos em negociação com a prefeitura.

Liza Fior, uma das fundadoras do Muf, e que ainda permanece à frente do grupo ${ }^{99}$, menciona que o modo original

Uma outra versão da análise desse projeto foi publicada por mim num artigo escrito para a revista editada pelo grupo de pesquisa de museus e patrimônio da FAU-USP-Ara Ymã n ${ }^{\circ} 4$ - Espaços em movimento (2018) - com o título "Participação entre campos".

Segundo Mel Dodd, que fez parte do grupo de 1997 a 2003, e que permanece como colaboradora próxima do grupo, o empenho em atividades processuais implica na necessidade de se reestruturar uma série de normas profissionais, estruturas de planejamento e condições administrativas para a sustentabilidade financeira de um escritório de arquitetura. Uma vez que o levantamento e o projeto se estendem, as encomendas, públicas ou privadas, dificilmente dão margem para serem renegociadas de forma a cobrir essas despesas, fator agravado por um não reconhecimento dessas etapas no rígido sistema de regulação do Instituto Real de Arquitetos Britânicos (RIBA), por exemplo. e teórica da arquitetura Katherine Schofield. Katherine Clark 
de atuar do Muf destacou-se quando surgiu no contexto inglês por questionar a autoria individual e voltar-se para a cidade e seu cotidiano, tendo como foco de suas intervenções as infraestruturas sociais, espaciais e econômicas na esfera pública. Segundo Fior:

Para algumas pessoas éramos suspeitas só porque éramos mulheres e compartilhávamos esse interesse pelo espaço público, vindas de disciplinas díspares como arte, arquitetura e teoria urbana, e durante a última administração conservadora, era super excêntrico interessar-se pelo espaço público. $\mathrm{O}$ dinheiro só era gasto em espaços públicos se você pudesse provar que estava trazendo investimentos privados para um bairro. Assim, o trabalho inicial do Muf foi uma crítica criativa disso. (FIOR, 2010, online, tradução minha' ${ }^{100}$ ).

A aproximação crítica diante das encomendas para uma reescrita de suas diretrizes, particularmente quando se trata de uma encomenda pública ou intervenção direta sobre o espaço público, tornou-se uma característica do grupo cujas abordagens se distanciam do protagonismo do projeto como elemento determinante das transformações do espaço, sem com isso preterir o emprego de um saber técnico específico.

Vale ressaltar que a diversificação das etapas de projeto não implica sua negação, mas a mobilização de equipes múltiplas e diversas, muitas vezes atravessando os limites dos papéis preestabelecidos, partindo sempre de um atento mapeamento dos atores envolvidos na configuração do espaço. O projeto, nesse caso, é um critério para a ação, cujo entendimento representa a garantia de sua viabilidade e a repartição das responsabilidades entre todos os participantes. Ou seja, o "princípio projetual” não

e Liza Fior permanecem até hoje como base permanente das diversas formações, uma vez que se organizam por meio de uma extensa e flutuante rede de colaboradores. Essa rede é tratada como uma árvore genealógica da história do grupo.

100 For some people we were suspicious just because we were women and shared this interest in public space while coming from disparate disciplines of art, architecture and urban theory. Back in 1995, during the last Conservative administration, it was super eccentric to be interested in public space. Money was only spent on public spaces if you could prove that you were bringing private investments into a neighbourhood. So muf's early work was a creative critique of that. 
é negado, mas se diversifica, sem que com isso se abra mão do necessário comprometimento com uma coerência interna, implícita à atividade e sua finalidade, o que não exclui uma autonomia conjectural do pensamento arquitetônico como construção intelectual. Como especulam Manuel Orazi e Pier Vitorio Aureli:

[...] um princípio projetual 'des-realiza' uma situação contingente por meio de uma abordagem analiticamente precisa e realista. Por esse motivo, o princípio projetual não pode se tornar a imprecisão do projetivo ou o puro narcisismo das boas intenções. O princípio do projetivo deve ser concretizado na singularidade absoluta de uma forma definida, cuja inteligibilidade escapa às armadilhas de imagens e ícones para impactar o coração de problemas e necessidades e sua verdade efetiva. (AURELI; ORAZI, 2006, p. 30, tradução minha $\left.{ }^{101}\right)$.

Segundo Dodd, abordagens projetuais como as do Muf admitem a complexidade e a instabilidade subentendidas em processos mais abertos, possibilitando "desvios entre o oficial e não oficial, o normativo e o ilegal, o planejamento e a informalidade ${ }^{102}$, muitas vezes negociando seus meios à medida que se apresentem" (DODD, 2017, p. 257), o que contribui para que relações sociais não acabem neutralizadas e espaços públicos desmobilizados e despolitizados por meio de uma intervenção arquitetônica. Também por esse motivo, seus projetos tendem a uma maior indeterminação de protocolos e usos, de modo que contribuam para que se explicitem as relações de força e, consequentemente, se favoreça a constituição de uma esfera pública.

Do original: "A project principle de-realizes a contingent situation through an ana- lytically precise and realistic approach. For this reason, the project principle cannot become the vagueness of the projec- tive or the pure narcissism of good intentions. The project principle must be concretized in the absolute singularity of a defined form, whose intelligibility escapes the traps of images and icons to impact the heart of problems and needs and their effectual truth".

102 "O texto, escrito originalmente em inglês teve sua tradução publicada em 2017 em um livro organizado por mim, Contracondutas, ação político-pedagógica, mas adquire melhor sentido em português com a revisão aqui proposta. 


\section{Indeterminação}

Há, portanto, um outro aspecto a ser considerado, que passa da abertura do processo projetual em suas etapas de análise e elaboração de necessidades - propensas a desvios programáticos para que se incorporem dissensos e imprevistos ao longo da elaboração do projeto -, para outro tipo de abertura, na qual o projeto estabelece graus de indeterminação que possibilitem a fluidez de uma dinâmica dos usos, acomodando transformações ao longo do tempo por meio de um afrouxamento do controle espacial determinado pelo programa e suas atribuições funcionais.

Contudo, o aparente paradoxo presente na ideia de um desenho aberto para indeterminação não significa uma invalidação de todo o legado histórico da prática profissional fundamentada na ação projetual. O que ocorre é uma produtiva tensão ao se admitir disjunções entre a obra e sua recepção, como uma lacuna entre intenção e resultado, que dá margem para o acaso e para as dinâmicas de interação do público, como em inúmeras experiências propostas pelo campo artístico ${ }^{103}$.

Não é à toa que um arquiteto que procurou explorar os limites disciplinares, como o suíço Bernard Tschumi, tenha se deparado com essa questão. Em sua produção de projetos teóricos ${ }^{104}$ e textos, ao longo dos anos 1970-80, Tschumi desenvolveu uma "teoria da disjunção arquitetônica”, criticando justamente a idealização distanciada dos usos praticada pelos arquitetos ao projetarem, em contraposição aos usos efetivamente realizados no espaço. Segundo o arquiteto:

103 O hiato entre intenção e resultado, assim como entre a produção e a recepção do trabalho de arte, atravessa a história do século XX. Basta pensar na importância que Duchamp conferia a experimentos com o acaso, desde 3 standart stoppages (1914), quando cria instruções que conduzem a resultados imprevistos a partir da forma como uma fita largada no ar se acomoda no chão, ou mesmo no modo como Le Grand verre (1915-1923) se compõe de imagens geradas por uma série de procedimentos casuais, até o modo como os efeitos do tempo, trincas e poeira, passam a fazer parte do trabalho. Mas o flerte entre aleatoriedade e controle dos resultados pode ser encontrado numa gama ampla de trabalhos, que incluem readymades, a pintura expressionista - caso do dripping de Pollock - e performances, entre outros.

104 Conforme a designação do próprio arquiteto, tanto suas especulações evidentemente conceituais, caso de The Manhattan Transcripts (1976-1981) e Screenplays (1976), quanto projetos construídos como o Parque de la Villette (1982-1998), em Paris, são projetos teóricos. 
Embora não se deva entender a noção de disjunção como um conceito arquitetônico, seus efeitos se imprimem no local, no edifício, e mesmo no programa, de acordo com a lógica dissociativa que rege a obra. Para definir disjunção para além do seu sentido nos dicionários, temos de insistir na ideia de limite, de interrupção. (TSCHUMI, 1988, p. 189).

Para Tschumi, a disjunção pode operar como uma ferramenta na qual o fazer arquitetônico é desviado do ideal de síntese enquanto premissa da lógica projetual, conduzindo a uma reorientação que produz questionamentos permanentes e extremos da ordem consolidada. Por isso sua aposta na ação do tempo sobre a obra, como dissociação entre espaço e tempo orientada à apreensão de condições instáveis e imprevisíveis. A partir da ação dos corpos, dos eventos e dos conflitos sobre o espaço, fatalmente ocorrerão disjunções, comprovando a incompatibilidade de "uma visão estática, autônoma, e estrutural da arquitetura” (TSCHUMI, 1988, p. 191).

São justamente essas necessárias relações de conflito, fruto de dinâmicas inconstantes e cambiantes das cidades contemporâneas que devem ser preservadas do excesso de controle exercido pela arquitetura, sob risco da total neutralização da esfera pública, conforme indicado por Mel Dodd ao argumentar sobre a postura do Muf.

Há, portanto, uma modulação das nuances entre a sobredeterminação do espaço e sua total indeterminação que passa por procedimentos empregados no projeto arquitetônico e seu programa, agindo sobre sua ordem diretiva como "uma espécie de 'funcionalismo invertido', com o uso sendo definido pelo usuário e não pelo conhecedor específico" (PERROTA-BOSCH, 2013, online). Algo que se concretiza de maneira exemplar no Vão Livre do MASP, que, como reconheceu John Cage ${ }^{105}$, se apresenta como "uma arquitetura da liberdade”, comportando-se como o silêncio de 4'33', ao desprender-se da estrutura fechada do compasso musical para disponibilizar-se para o ruído da vida.

Consequência de um complexo encadeamento de circunstâncias históricas e embates políticos - como

Em referência ao conhecido depoimento de Lina sobre seu encontro com Cage em Uma aula de arquitetura (GRINOVER;RUBINO, 2009, p. 166). 
será tratado no capítulo 3 desta tese - e resultado de uma inventiva intenção de Lina Bo Bardi, o Vão Livre se apresenta como um espaço que participa do todo projetado para o Museu de Arte de São Paulo, sendo emoldurado por ele. No entanto, ele se concretiza como um espaço aberto a apropriações e situações imprevistas, o que transparece nas falas da arquiteta sobre a função "coletiva e sociopolítica” (BARDI, L., 2009, p. 165) da arquitetura e sobre o desenho de uma "obra que sirva, que tenha uma conotação de uso, de aproveitamento” (BARDI, L., 2009, p.165).

Assim, espaços indeterminados e adaptáveis são cada vez mais uma demanda programática, particularmente em edifícios públicos, nos quais a acomodação de vários usos demanda flexibilidade para o aproveitamento coletivo no longo prazo. Uma conjuntura que faz com que Lacaton e Vassal remetam à sua vivência no norte da África como contexto essencial para sua interpretação de modos simples, fluidos e eficazes de organização do espaço que repercutem tanto em sua prática quanto $\mathrm{m}$ sua abordagem conceitual.

É como praça aberta que Lacaton e Vassal se referem às grandes áreas da Escola de Arquitetura de Nantes (2009), para as quais não são atribuídas funções específicas, de modo que alunos e professores possam ocupá-las como bem entenderem, impactando diretamente o princípio pedagógico da escola, como um lembrete constante das possibilidades de reinvenção do programa - do espaço às atividades acadêmicas.

E é também como uma grande praça que interpretam o edifício construído para a Feira Mundial de 1937, readequando-o para a implantação do centro de arte contemporânea, o Palais de Tokio (2001/2014), em Paris. Sua referência conceitual parte da Praça Jemaa el-Fna, em Marrakech ${ }^{106}$ - uma grande área descampada no miolo da cidade, que já foi uma importante mesquita -, e da maneira como é reconfigurada e transformada cotidianamente pelo fluxo diário dos vendedores ambulantes, acrobatas, curandeiros, músicos, dançarinos, e barracas de comida típica. Outra referência declarada é o projeto para o Fun Palace (1960-61) ${ }^{107}<$ imagem C2.4 p.147>, de Cedric Price.

106 O mercado tornou-se Património Cultural Imaterial da Humanidade da Unesco em 2008. 
O Palais de Tokio foi pensado em diálogo próximo com os curadores Nicolas Bourriaud, e Jérôme Sans, no intuito de garantir que um máximo de espaço do grande pavilhão de $16.500 \mathrm{~m}^{2}$ permanecesse acessível, assegurando que seu potencial de uso possa ser explorado livremente pelas exposições, sem o engessamento em uma única configuração.

Possibilitando ocupações diversas, flexíveis e independentes dos espaços, Lacaton e Vassal delegam suas redefinições constante aos artistas, curadores e visitantes - uma proposta que se coloca como oposição ao diagnóstico de complexo arte-arquitetura de Hall Foster, como se se tratasse de uma síndrome ou desiquilíbrio das relações entre artistas e arquitetos, afirmada principalmente pela exacerbação formal da arquitetura do início dos anos 2000.

De fato, uma característica do projeto é o despojamento dos acabamentos e a maneira como camadas desnecessárias foram removidas sem que se adicionassem novos revestimentos, revelando o estado da construção como ela é, com sua aparência gasta, inacabada e de quase ruína; um posicionamento que rebaixa a importância dos acabamentos e dos excessos formais ${ }^{108}$, ao mesmo tempo em que nega a galeria como cubo branco, neutro.

Para o arquiteto Alejandro Zaera-Polo, essa estética se aproxima da arte póvera, como um recuo de viés político contra o domínio dos efeitos econômicos sobre o agenciamento da produção arquitetônica. Se o pós-moderno explorou a dissociação entre estilo e valor de maneira cenográfica, como uma transfiguração especulativa voltada ao mercado, a "estética do barato" do Palais de Tokio provavelmente o metro quadrado construído mais barato para a reforma de um museu, segundo Zaera-Polo - explora o custo como argumento do projeto (ZAERA-POLO, 2010, p. 15-27).

setembro de 2000, o projeto do Fun Palace foi realizando durante um ano, entre 1960 e 1961, embora muitos meios o divulguem como um projeto desenvolvido entre 1960 e 1964. (PRICE; OBRIST, 2009, p. 74).

Uma resposta ao orçamento e à demanda por área, de modo a garantir o menor custo de metro quadrado possível, característica pela qual Lacaton e Vassal são reconhecidos. Há um consenso sobre a qualidade do desenho por trás da austeridade material de sua obra, empregando técnicas construtivas de baixo custo apropriadas durante décadas de pesquisa voltadas à concepção de sistemas construtivos leves e adequados à flexibilidade de seus projetos. 
Por outro lado, como aponta Claire Bishop - uma das principais críticas do termo "arte relacional” -, a orquestração entre instituição e sua arquitetura despojada, que resulta no projeto para o Palais de Tokio, tornouse uma espécie de paradigma europeu de instituição de arte à procura de "reconceitualizar o modelo do cubo branco". Instituições que abraçam o modelo de "laboratório interdisciplinar" ou de "estúdio experimental", como forma de se diferenciarem de "museus baseados em coleções e sobrecarregados pela burocracia”, conferem à arte contemporânea um sentido de constante fluxo e incompletude, facilmente capitalizado pela instituição como espaço de lazer e também de entretenimento numa “economia da experiência”, e pelo curador, que conquista capital cultural por criar as condições dessa experiência (BISHOP, 2004, p.51-79).

A crítica de Bishop, sempre aguçada ao endereçar as contradições de uma adesão incauta a modismos e jargões que, de tempos em tempos, acometem o campo artístico, foi precisa ao estabelecer um contraponto à Bourriaud e à “arte relacional”. Para a autora, há um entusiasmo com práticas artísticas que, a partir dos anos 1990, disseminamse fora dos estúdios dos artistas, próximas de contextos específicos e orientadas para preocupações sociais, o que corresponde, em sua análise, a uma tendência à arte participativa, abarcando uma variedade de modalidades referidas a termos como "arte socialmente engajada, arte baseada na comunidade, comunidades experimentais, arte dialógica, arte intervencionista, arte participativa, arte colaborativa, arte contextual e, mais recentemente, práticas sociais" (BISHOP, 2012, p. I). O que todas essas práticas têm em comum, segundo a autora, é sua centralidade no envolvimento de pessoas como meio e matéria da produção artística.

Sua crítica, claramente, não invalida toda essa produção, mas pontua termos para sua análise e atenta para os riscos de uma instrumentalização da arte participativa como uma suave engenharia social, edulcorada e distanciada de seu contexto real (BISHOP, 2012). Esta preocupação é igualmente necessária quando arte e arquitetura se aproximam de uma prática espacial crítica, na qual o processo é enfatizado, mais do que uma síntese ou imagem definitiva, e o conceito passa a refrear a produção de objetos. Ou seja, desloca-se o sentido da forma resultante para a 
maneira como os espaços são produzidos e utilizados.

Diante da notável diversificação que essas formulações representam para a arquitetura, quando tensionada a metodologia ortodoxa do projeto, e à medida que o programa de necessidades se converte no 'lugar específico', amplia-se a importância de uma poética voltada à consciência crítica sobre contextos e o espaço social onde se intervêm - o que implica também a reorganização dos papéis desempenhados por arquitetos a partir de parâmetros críticos.

A aproximação entre arte e arquitetura, nesse sentido, se estabelece por estratégias e procedimentos empregados para uma construção conceitual, processual e crítica, atenta ao seu embate com o cotidiano e o público, e ao valor de uso dos espaços. 


\section{Projeto}

\section{participação}

Pensar arquitetura como construção de sistemas abertos foi a grande ocupação de Yona Friedman, o heterodoxo arquiteto húngaro radicado na França e firme crítico da positividade que atravessou a sociedade no pós-guerra.

Tendo sobrevivido à Segunda Guerra e se engajado nos movimentos de resistência e sionista, Friedman relata que o contato com a mitologia e a ciência ${ }^{109}$, no seu período de formação, quando ainda jovem na Hungria, foram uma abertura determinante para que intuísse a possibilidade de construir sistemas. Também as experiências limite durante a guerra o colocaram em contato com estratégias de guerrilha e uma sensibilidade para soluções aplicadas e reais, envolvendo o engajamento de não especialistas.

O interesse pelos usuários levou Friedman a desenvolver sistemas construtivos que pudessem ser manipulados e transformados, como objetos inacabados ou como uma obra aberta, em que a forma é um fator secundário. Isso quer dizer que sua proposta compreende as necessárias soluções para questões técnicas, como um sistema construtivo composto por elementos replicáveis e possíveis de serem manipulados. Mas a solução técnica é pensada para servir como uma das diretrizes 'disparadas' pelo arquiteto, tendo em vista um sistema projetual aberto e apreensível por todos os participantes. Contribuindo, dessa forma, para que a tomada de decisões envolva seus futuros usuários, inclusive na definição das dimensões dos ambientes e sua distribuição no todo, cabendo ao arquiteto

109 Esta ligação entre ciência e mitologia é apresentada por Manuel Orasi, autor de Yona Friedman:The Dilution of Architecture (2015), um livro baseado em sua pesquisa de doutorado escrita ao longo de diversas entrevistas com Friedman, dentre as quais "A Conversation with Yona Friedman” (2012), dedicado a "abordagens cautelosas e esperançosas para o design digital e de código aberto, bem como abstrações, aforismos e tratamentos literários da arquitetura” -, Werner Heinsenberg, prêmio Nobel de física em 1932, e Károly Kerényi, um filólogo especializado em mitologia, informaram as reflexões de Friedman sobre inteligência coletiva, espontaneidade e imprevisibilidade inerente aos sistemas. 
apenas um gerenciamento dessas definições. Nas palavras do arquiteto:

Não era um projeto com fachada e então outras coisas. Isso significava que seria completado pelos habitantes e mudado pelos habitantes. [...] minha proposta não era arquitetura, nem arte; não era um objeto final. Era o começo de um processo, e os edifícios podiam parecer completamente diferentes. O uso não era determinado. (FRIEDMAN, 2012, p. 69, tradução minha) ${ }^{110 .}$

O que parece simples em tese, sem dúvida encontrou resistência para sua efetiva implantação, uma vez que esse procedimento desconstrói princípios de controle mediados pelo desenho. Ainda que ao arquiteto fosse garantida a gestão do processo e o controle técnico e financeiro para sua realização, houve um deslocamento de seu papel de autor para o de coordenador da ação participativa aplicada às etapas de projeto.

Nesse sentido, uma das poucas experiências de Friedman levadas a cabo foi uma escola em Anger, na França, em 1978, da qual chegou a ser afastado do processo por agentes locais, retornando por exigência do grupo de usuários envolvidos no projeto. Utilizando diagramas <imagem C2.5 p.148>, os espaços e a distribuição do programa foram determinados coletivamente, e construídos respeitando o desejo de longas circulações entremeados por pátios de descanso, o que contrariava as determinações burocráticas. Fiel a seus princípios, dentre eles o de negar a estabilidade e permanência da forma arquitetônica, Friedman assegurou uma abertura para a futura transformação do edifício após a sua ocupação, e seu comprometimento com essa abertura facilitou a descaracterização do projeto e sua conversão para uma escola convencional alguns anos depois.

A dificuldade em efetivar processos de projeto como sistemas abertos talvez explique a razão de as especulações

No original: "It was not a project with a facade and then other things. This meant it would be completed by the inhabitant and changed by the inhabitant. [...] my proposal was not architecture, not art; it was not a final object. It was the start of a process, and the buildings could look completely otherwise. The use was not determined". 
não construídas de Friedman serem mais conhecidas do que suas proposições realizadas, e de terem sido protagonistas do recente resgate de seu trabalho pelo campo da arte, quando, após um longo período de isolamento do debate público, participa da Documenta 11 (2002), em Kassel, das Bienais de Arte de Veneza de 2003 e 2005, e do Panorama da Arte Brasileira, em 2013, no MAM, em São Paulo ${ }^{111}$.

A retomada de interesse pelo trabalho de Friedman foi motivada pela atualidade de seus questionamentos, tanto pela forma como suas investigações promovem o protagonismo do público na tomada de decisões quanto por sua provocação para uma "arquitetura sem edifício"112. Trata-se de especulações que mobilizam hoje um imaginário de transformação espacial relevante para o enfrentamento das ameaças de esgotamento ecológico, em um mundo sobrecarregado de construções e no qual o esgarçamento do tecido social no ambiente urbano amplifica a demanda por uma gestão partilhada e inclusiva das responsabilidades sociopolíticas.

Sua Vila Espacial (1959), formulada como conceito na ocasião em que o arquiteto participou do X Congresso Internacional de Arquitetura Moderna (1956), organizavase como uma superestrutura espacial de múltiplas camadas, suspensa por grandes colunas com intervalos de 40 a 60 metros, que poderia recobrir cidades tão distintas quanto Paris (1970) <imagem C2.6 p.149>, Nova Iorque (1964), ou Medina (1959), e responder à necessidade de adensamento das cidades sem demolição de áreas existentes ou expansão territorial. O sistema, tecnicamente desenvolvido pelo arquiteto, possibilitava a convivência de diversos usos

111 Yona Friedman é um dos arquitetos-artistas convidados, apresentando um conjunto de desenhos manifesto para o museu sem edifício, no qual é a exposição que define o espaço do museu. Os desenhos são acompanhados das seguintes frases: "É a exposição que faz o museu”; "o edifício em si, é caro e supérfluo"; "você pode criar um museu sem edifício"; "um suporte expositivo de andaimes pode fazê-lo” (FRIEDMAN apud LAGNADO; MAIA, 2013, p.186).

112 Arquitetura sem Edifício (2012) é também o título de um livro editado pelo CNEAI, um centro de arte contemporânea francesa voltado a pesquisa e fomento de práticas culturais colaborativas, que vem publicando a obra de Friedman. No livro, referenciando a importância histórica da exposição de Bernard Rudofsky Arquitetura sem Arquitetos (1964), realizada no MoMA, Friedman defende a ideia de uma reconfiguração do papel do arquiteto a partir da descentralização da importância do edifício transformando-se numa gestão do espaço. 
organizados por meio da ocupação coletiva de módulos de 6 X 6 metros, servidos por toda infraestrutura necessária, e pelas células construídas pelos próprios habitantes.

Trata-se de um evidente enunciado sobre seu ponto de vista acerca do papel do arquiteto, encarregado de pensar a grande infraestrutura urbana como meio oferecido para a articulação de células flexíveis, autoconstruídas e reguladas por seus habitantes.

Segundo os arquitetos e pesquisadores Manuel Orazi e Pier Vittorio Aureli - este último que também integra o grupo Dogma ${ }^{113}$-, os desenhos para a Vila Espacial foram mal interpretados e erroneamente associados às propostas utópicas que a sucederam, como as de Constant ${ }^{114}$, Archigram e Superstudio, de quem Friedman procurou se diferenciar, por considerar tais propostas abstratas e desengajadas demais, resultando, segundo Orazi e Aureli, na suspensão de suas especulações gráficas, nos anos 1970, para que não se confundissem com uma imagem de "carimbo formal” (AURELI; ORAZI, 2006, p. 28).

O meio gráfico é substituído pela escrita como lugar de elaboração para suas concepções de auto-organização da sociedade, sendo sistematizadas no livro Utopias Realizáveis (1974) ${ }^{115}$, onde abarca um pensamento utópico,

Escritório fundado em 2002 por Pier Vitorio Aureli e Martino Tattara, dedicado a projetos urbanos de grande escala e à pesquisa com intensa produção gráfico-teórica.

Em entrevistas concedidas ao curador Hans Ulrich Obrist, entre 1998 e 2002, Friedman afirma que, apesar de ter conhecido e se correspondido com o artista holandês Constant Nieuwenhuys, - integrante do grupo CoBrA e autor do plano da cidade situacionista Nova Babilônia (1959)

- "o modo de pensar de Constant era o que chamo no meu livro de uma utopia paternalista: uma utopia baseada no 'alguém que sabe'. Meu ponto de vista era exatamente o oposto: 'não sei'... De certo modo, Constant age como um 'maitre de ballet', criando um balé muito bonito inventado exclusivamente por ele. Quanto a mim, não interfiro no que os verdadeiros artistas fazem. Eu nem sei o que eles fazem; para mim é suficiente se eles estão satisfeitos. A diferença entre o balé e as pessoas na rua expressa nossa diferença conceitual. Um balé pode lembrar a multidão da rua, e uma multidão pode lembrar um balé, mas eles são estruturalmente completamente diferentes". (FRIEDMAN entrevista concedida à OBRIST, 2003 - p. 239, grifo meu)

Utopies réalisables foi escrito em 1974 e reeditado no ano 2000. Segundo Manuel Orazi e Pier Vitorio Aureli, no artigo “The Solitude Of the Project", existe um princípio projetual neste trabalho de Friedman, que recorre a desenhos esquemáticos, aliados a textos de linguagem direta e de fácil compreensão, elementos característicos de toda sua obra, com o objetivo de esboçar uma visão social utópica como realidade desejável e possível de ser construída por meio de 
aberto à criação de uma ecologia social diversa, com o propósito de integrar autogestão e boas soluções urbanas. Há, portanto, um deslocamento de seus projetos de uma esfera voltada à construção para uma outra, voltada à constituição de um campo discursivo mediante uma argumentação propositiva e direta ${ }^{116}$ - o que para Aureli e Orazi representa uma alternativa à teoria e sua tendência de abstração e descolamento da realidade, "desprovida de qualquer tensão pública” (AURELI; ORAZI, 2006, p. 32). Com isso, os pesquisadores ressaltam a importância do projeto de Friedman como uma ética aplicada, ou como "um protesto, uma contraproposta vis-à-vis formas institucionais de tomada de decisão pública, e também como uma teoria fundadora que esclarece uma hipótese de governança” (AURELI; ORAZI, 2006, p. 31).

Aspectos deste tipo de raciocínio são reconhecíveis em formulações contemporâneas como as do escritório chileno ELEMENTAL, coordenado pelo arquiteto Alejandro Aravena, curador da $15^{\mathrm{a}}$ Bienal de Arquitetura de Veneza, e prêmio Priztker de 2016. Em projetos como a Quinta Monroy (2003) <imagem C2.7 p.150> e a Habitação Villa Verde (2010), com objetivo de garantir o acesso à infraestrutura básica para um maior número de famílias mantendo o custo mínimo adequado ao investimento público disponível, as unidades habitacionais são construídas de forma a permitir aos moradores expandir até o dobro de sua área inicial e concluir suas unidades de acordo com seu desejo e disponibilidade de recursos.

A tensão pública e a urgência para que se apresentem soluções com impacto concreto foi o que motivou Aravena, em seu discurso curatorial, a fazer da $15^{\mathrm{a}}$ Bienal de Arquitetura de Veneza, com o título Reporting From the Front [Relatos desde o fronte ] (2016), uma provocação aos

ações claras e de explicação racional. Ainda segundo os autores: “Friedman se opõe ao otimismo como vontade de acreditar que é a própria comunidade que cria sua própria forma reconhecível; e embora isso seja gerado pela auto-organização, considerada um mito impossível até hoje, sua realização supõe paradoxalmente a existência de um princípio de projeto" (AURELI, ORAZI, 2006, p. 29-30).

116 Essa preocupação de comunicação ampla e direta por parte de Friedman corresponde ao que ele se referia como um 'direito de entender', e que, de acordo com uma entrevista concedida à Hans Ulrich Obrist, significa que "toda experiência do homem pode ser expressa em linguagem compreensível” (OBRIST, 2003, p.235) 
arquitetos para que assumissem uma posição diante das competências profissionais, e reformulassem qualquer possibilidade de idealização utópica distanciada da realidade - uma posição associada a uma visão eurocêntrica de mundo que domina as curadorias das bienais internacionais.

Para explicar sua proposta, o arquiteto chileno partiu de uma fotografia feita nos anos 1970 pelo romancista e escritor de viagens inglês Bruce Chatwin, que retrata a antropóloga alemã Maria Reiche no deserto de Nazca. Do ponto de vista de quem está com os pés no chão, é possível avistar apenas um monte de pedras a perder de vista, mas Reiche, do alto de sua escada de mão de alumínio, encontrou uma outra perspectiva para descortinar pássaros, flores e animais, e documentar mais de cinquenta geóglifos munida apenas de caderneta, bússola e fita métrica. Uma estratégia que garantiu à antropóloga sua independência em relação aos caros sobrevoos, conferindo agilidade ao trabalho.

Essa é a analogia proposta por Aravena: encontrar meios que possibilitem identificar novos pontos vista para a prática da arquitetura reconhecendo que, para o enfrentamento dos problemas sociais globais, é necessário ampliar a perspectiva de atuação profissional de modo que se evidencie a importância de processos e suas circunstâncias - o que envolve reconhecer as diversas forças em disputa, as limitações e os artifícios para que se atinjam resultados capazes de impactar a qualidade de vida das pessoas.

Por essa razão, Reporting From the Front foi reconhecidamente a edição da Bienal de Veneza mais carregada de preocupação social desde a origem do evento, em 1980, apresentando exemplos que oferecem resultados expressivos com baixo impacto econômico e ambiental, características fortemente presentes na arquitetura latinoamericana contemporânea.

Assim, não é casual que essa edição tenha contado com a participação do Peru, tenha concedido o Leão de Ouro de melhor participação ao arquiteto paraguaio Solano Benitez e seu Gabinete de Arquitectura, e tenha sido o ponto de partida para a realização do documentário Hacer mucho con poco (2018), produzido após o interesse em torno da participação do grupo equatoriano Al Borde ${ }^{117}$. Uma evidente reorientação

Grupo de arquitetos, baseado em Quito, Equador, formado em 2007 por Pascual Gangotena, David Barragán, Marialuisa Borja e Esteban 
política que enfatizou pela primeira vez na história do evento a importância do que vem sendo produzido na América Latina.

O documentário Hacer mucho con poco retrata como uma geração de arquitetos equatorianos criou condições para a prática arquitetônica diante das condições adversas impostas pela crise econômica de 2008. A produção de diversos escritórios de arquitetura equatorianos retratada no filme conquistou visibilidade internacional ao demonstrar como foram capazes de reverter a escassez de recursos em resultados de alta qualidade, por meio de um desenho inventivo realizado junto a comunidades com necessidades reais de intervenção arquitetônica, tanto nas cidades quanto no campo, e em situações normalmente distantes das pranchetas desses arquitetos, de forma geral, limitados a responder demandas comercialmente viáveis.

A gestão de recursos como um mecanismo de projeto ocorre por meio da valorização do contexto, com seus fatores materiais e humanos, há um empenho de todas as partes nas soluções de programa e de técnicas construtivas, assim como um caráter "mão na massa” por parte de todos os envolvidos, inclusive estudantes e residentes ${ }^{118}$. O agenciamento sistêmico de todo esse contingente sócio-econômico é a essência do modo de agir do Al Borde, que acredita ser esta a riqueza invisível de sua prática, ao que se referem como 'recursos escuros'. Ou seja:

"a matéria escura e a energia quase desconhecidas que constituem a essência real de todo o universo.No nosso caso, os recursos escuros são representados pelo atendimento de nossas necessidades e das ferramentas disponíveis.Eles não são extraordinários, mas comuns e acessíveis,

Benavides. In: http://www.albordearq.com/ .Acesso em 17 jan. 2020.

118 Vários fatores estão envolvidos no modo de produção do Al Borde, que procura estabelecer um cotidiano produtivo e comunitário baseado num encadeamento de dinâmicas econômicas alternativas. O que envolve o combate da precariedade das condições de trabalho pela valorização e preparo do almoço por todos no escritório, pela otimização do trabalho para reduzir a semana a 4 dias úteis - uma rebelião contracultural dadas as extensas jornadas de trabalho comumente (mal) remuneradas por hora nos escritórios de arquitetura -, e uma atuação mais próxima junto aos estúdios práticos na Universidade, que envolve também um projeto de residência internacional para recepcionar colaboradores interessados em contribuir durante seis meses com o grupo. 
provenientes de fontes não convencionais e escapando às lógicas do mercado.”(AL BORDE, 2016, online, tradução minha).

Desse modo, o Al Borde, ao lado de sua geração, acabou estabelecendo um lugar privilegiado para endereçar uma resposta concreta e crítica ao setor da construção civil e seus mecanismos de desvalorização de toda a cadeia produtiva, do arquiteto à mão de obra no canteiro de obras, da matériaprima empregada e sua sustentabilidade ao catastrófico impacto urbano, quando a lógica de mercado controla todo o planejamento urbano. Por isso mesmo, o Al Borde abre os orçamentos de suas obras e de todos os projetos incluídos no documentário Hacer mucho com poco, de forma a explicitar o desequilíbrio do mercado e dos valores por metro quadrado espantosamente baixos que conseguem alcançar.

Há, portanto, uma ação pela qual os meios de produção e publicização dos trabalhos são mobilizados de modo encadeado, para com isso alavancar especulações espaciais e críticas como no projeto para o Pavilhão Alemão HIII (2016) e sua indissociável continuidade no Protótipo para um centro comunitário pós terremoto (2017) <imagem C2.8 p.151>. Uma operação que se efetiva no contexto real, mas que estabelece correspondências com deslocamentos discursivos, e vice-versa.

\section{Os mutirões autogeridos em São Paulo}

A reprodução do espaço como fator de exclusão ao acesso à moradia digna na cidade de São Paulo engendrou experiências de grande relevância no contexto latinoamericano diante dos desafios não superados pela arquitetura moderna. A explosão urbana e o consquente inchaço das periferias, que cresceram sob a lógica da autoconstrução, de ocupações irregulares e à revelia de qualquer participação dos arquitetos e do planejamento urbano do Estado, estabelece o contexto no qual surgem os mutirões autogeridos, nos anos 1990.

As assessorias técnicas formadas nesse período reúnem um rico repertório de ferramentas ${ }^{119}$ empregadas para uma 
reconfiguração da prática profissional. Reconfiguração esta que requer projetar em outro registro, no qual soluções técnicas, programáticas e de formalização estejam voltadas para a transformação da construção informal juntamente com os movimentos de moradia em formação naquele momento.

A Usina Centro de Trabalhos para o Ambiente Habitado (Usina CTAH), e outras assessorias técnicas que se diversificaram no ambiente da redemocratização passaram a enfrentar a limitação do planejamento público atuando para estimular a autogestão da construção de moradias como resposta para a urbanização das periferias. Um direcionamento que permite uma formulação original para inquietações que se amplificaram e se disseminaram globalmente ao longo das décadas seguintes, tornando-se urgentes na atualidade, e sintetizadas com precisão por Keller Easterling, professora e pesquisadora de Yale, no texto Stones in the Water (2012), onde pontua:

“Os arquitetos estão fazendo pedras ocasionais na água. O mundo está fazendo água” (EASTERLING, 2012, p.41, tradução minha) $)^{120}$.

Essa condição de distanciamento da produção e da esfera de decisões que determina o desenho das cidades e o acesso a direitos básicos é essencial para entender o surgimento das assessorias técnicas, notadamente da Usina, e a maneira como passaram a desempenhar um papel ativo para a conversão do canteiro de obras em um lugar de colaboração e formação técnica para a transformação social. O emprego de processos participativos, com debate coletivo das possibilidades e soluções, passa posteriormente por uma "transcrição gráfica" (FERRO, 2015, p.26) com o objetivo de compartilhar os saberes sobre as técnicas construtivas a serem empregadas na organização da produção no canteiro de obras.

usuários" (USINA CTAH, 2015, p. 157). No texto "Processos de Projeto como Construção de Autonomia" (2014), escrito por Isadora Guerreiro e Kaya Lazarini, a partir de debate com as equipes da Usina, o projeto arquitetônico é problematizado a partir da experiência do grupo diante dos enfrentamentos que se apresentavam a cada projeto, e das ferramentas acumuladas para apoiar a autogestão, a participação, o direito à cidade e a tecnologia, compreendidos como um processo único. O texto foi reeditado para integrar o livro Usina: Entre Projeto e Canteiro (2015).

120 No original: "Architects are making the occasional stone in the water. The world is making water". 
O projeto desenvolvido pelas equipes técnicas funciona por seu trânsito entre o debate e a "transcrição gráfica", como elemento mediador de uma prática didática. É a peça que auxilia na comunicação social e embasa a tomada de decisões coletivas, manifestando-se como elemento fundamental para a luta por melhoria na qualidade da moradia de interesse social e como alternativa aos modelos existentes, uma vez que reverbera na revisão dos termos de contratação dos serviços, na qualidade das condições de trabalho no canteiro de obras, e na qualidade dos espaços que proporciona. O projeto opera, portanto, como um contraponto ao sistema hegemônico ao voltar-se para "a emancipação política, a solidariedade e construção de um bem comum" (USINA CTAH, 2015, p.156) instaurando, por meio do projeto, um processo horizontal de produção e uma retomada da noção de comunidade autogerida.

Esse modo de projetar passa por uma constante revisão e adequação de suas práticas às novas experiências, e constitui um sofisticado acervo de experimentações participativas na concepção, construção e gestão de recursos e fundos. Segundo o arquiteto Sergio Ferro (2015, p. 23):

O projeto e a construção propriamente ditos não são quase nunca os marcos iniciais de seu relacionamento com o grupo e sua organização. Antes, os membros da Usina examinam detalhadamente as condições indispensáveis para viabilizar sua esperança. Como obter terreno, financiamento, meios de produção, condições de trabalho. Como chegar a um acordo sobre o que fazer para obter tudo isto, pedir, pressionar, enrolar, ocupar, etc. Como estruturar o grupo para enfrentar, talvez, por longo tempo, as inúmeras tarefas indispensáveis, as várias responsabilidades, com quais regras de conduta, prioridades, etc., etc., etc. Por um bom tempo, o trabalho comum do grupo e da Usina se concentra em torno da obtenção das condições para produzir e da antecipação do futuro sujeito coletivo desta produção.

A abordagem do projeto que se diversifica em inúmeras atividades e se desdobra em etapas complexas e mais extensas para sua concretização foi aperfeiçoada pela Usina através da atuação de equipes multidisciplinares. Essas 
equipes se renovam e se reorganizam de acordo com as demandas e orçamentos disponíveis, mantendo sempre uma isonomia salarial entre todos os envolvidos - característica que faz da Usina uma plataforma fundamentada sobre os mesmos princípios participativos que aplica em seus projetos.

Preocupada em cuidar da publicização e inserção desse arquivo de experimentos em meios que pudessem expandir o debate circunscrito à arquitetura, a Usina também recorreu a linhas de financiamento da área cultural, e contou, entre 2009 e 2014, no seu quadro composto por diversos colaboradores, com a participação da artista Graziela Kunsch.

Tendo se aproximado da Usina em virtude de seu trabalho ativista com movimentos sociais, Kunsch inicialmente foi convidada a se juntar a Paula Constante ${ }^{121}$ para desenvolver uma oficina de produção de vídeo para a realização de um documentário durante o Mutirão da Comuna Urbana Dom Helder Câmara (2008-2012), do Movimento dos Trabalhadores Rurais Sem Terra (MST), na cidade de Jandira, interior de São Paulo.

Contudo, os rumos da produção desse documentário acabaram se desviado da intenção original de Kunsch, que propunha pensá-lo como uma estrutura radicalmente aberta - sem autoria ou dispositivo pré-determinado para a edição futura, no qual a câmera de vídeo circularia livremente entre os participantes, sem que houvesse antes instruções ou preparo. As exigências do edital de financiamento, e a resistência por parte de alguns mutirantes em aderir à produção do vídeo ${ }^{122}$, fez com que o documentário fosse adaptado a um roteiro mais linear na sua etapa de pósprodução. Apesar desse fato, a participação da artista já era reconhecida por seu envolvimento nas diversas atividades da Usina, e ela foi integrada à equipe antes mesmo da conclusão desse projeto.

Ao longo desse período, ocorre uma intersecção entre a prática de Kunsch e os projetos da Usina. Fato que contribui

121 Arquiteta que integrou a Usina e que se direcionou para o cinema, com o qual já se envolvera desde a produção documentário Capacetes Coloridos (2007), seu projeto de conclusão de curso na FAU-USP.

122 Segundo depoimento da artista, em entrevista realizada no dia 4 de out. de 2019, houve uma resistência por parte de participantes do movimento em aderir ao processo de documentação e captação de imagens, compreendida como uma atividade secundária, ou um desvio da causa central da luta pela moradia. 
para uma análise dos trânsitos entre arte e arquitetura como campos que se tangenciam ao longo história, particularmente quando aproximados por sua relação inextricável com a política, como base estética e forma de experiência, conforme conceituado pelo filósofo Jacques Rancière, em A partilha do sensível. Estética e política (2005).

Denomino partilha do sensível o sistema de evidências sensíveis que revela, ao mesmo tempo, a existência de um comum, e dos recortes que nele definem lugares e partes respectivas. [...]Essa repartição das partes e dos lugares se funde numa partilha de espaços tempos e tipos de atividade que determina propriamente a maneira como um comum se presta à participação e como uns e outros tomam parte nessa partilha. (RANCIÈRE, 2005, p.15).

O senso de comum elaborado a partir do fortalecimento das coletividades, no caso da parceira de Kunsch com a Usina, cruza limites disciplinares e estabelece trânsitos que faz com as identidades sejam múltiplas, o que desestabiliza lugares sedimentados de prática. Não somente os códigos e protocolos dos espaços são desafiados pelas coletividades e pela participação ${ }^{123}$, mas também as identidades oscilam entre o “artista/ativista, teórico/profissional, participante/espectador, organizador/organizado” (WRIGHT apud SHOLLETE, 2006, p. 5). E por que não artista/arquiteto, e vice-versa?

$\mathrm{O}$ atravessamento entre ativismo político, artístico e a arquitetura é agenciado por Kunsch como construção de práticas dialógicas ${ }^{124}$ que se utilizam de processos educativos,

Mais do que uma mobilização do debate em torno de uma "estética relacional” ou de uma “arte participativa” já trabalhados no primeiro capítulo desta tese, como concepções que tentaram abarcar uma arte conectada a processos e práticas sociais pelo envolvimento do público - não mais compreendido como espectador passivo - interessa estabelecer um contraponto entre essa 'maneira de fazer' e a normalização de conflitos, encenados de forma dúbia e recorrente em museus, festivais e bienais desde a virada do milênio e reportados à esses conceitos.

“Resumidamente, trata-se de projetos artísticos onde se pode identificar uma forte inclinação educativa. Não uma educação disciplinar, mas uma educação baseada no diálogo, na troca de experiências, no compartilhamento de estudos, no aprendizado mútuo, enfim” (KUNSCH, 2016, p.3). 
também caros à Usina, para instaurar a coletividade em galerias, espaços expositivos, assembleias em canteiros de obras, ou em debates e aulas. Por meio deste diálogo, é estabelecida uma significativa ponte entre arte e arquitetura, e entre prática e reflexão crítica, a exemplo da elaboração de textos assinados pela Usina, que circularam em outros contextos a partir da Revista Urbânia ${ }^{125}$, ou na forma como essa interação afeta os desdobramentos de seu Projeto Mutirão (2005-), uma pesquisa aberta que assume diversas formas de exibição na busca por criar situações - performances, aulas, conversas - visando à construção de um pensamento coletivo para lutas políticas na cidade.

Quando convidada a integrar a 29a Bienal de São Paulo (2010), a artista ocupou o espaço expositivo exibindo quatro filmes de seu Projeto Mutirão, e trouxe à público sua biblioteca de livros sobre utopias, projetos de cidade, educação e autogestão, além de um arquivo de excertos ${ }^{126}$ organizados em uma plataforma digital de software livre. Realizadas nos terreiros $^{127}$ presentes naquela edição, cada sessão transferia para o público o controle sobre a combinação e a ordem de exibição. O debate disparado a partir dessa articulação

125 A Revista Urbania nasce como projeto da artista em março de 2001, originalmente com pequena tiragem para a livre reprodução a partir de uma estratégia de distribuição que contava com a multiplicação por parte de diversos coletivos de artistas ativistas. A $3^{\text {a }}$ edição, com o tema "Direito à Cidade" - que integra o projeto Arte Esfera Púbica (2008), contemplado no Edital Conexão Artes Visuais MinC-Funarte-Petrobras -, traz o texto "Arquitetura, política e autogestão. Um comentário sobre

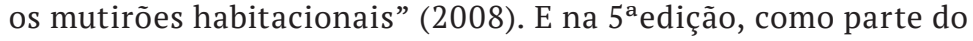
trabalho de Graziela Kunsch em colaboração com o Educativo da $31^{\text {a }}$ Bienal de São Paulo, a revista publica o artigo "Processos de projeto como construção de autonomia”, ambos da Usina.

"Chamo estes planos de excertos, tanto para explicitar esse processo de tão somente extrair um trecho de horas de observação (sem uma edição posterior/ou junção com outros planos) como na tentativa de dizer que se trata de momentos, de peças de um processo maior. A cada apresentação escolho excertos diferentes para mostrar narrativas únicas que não se repetem" (KUNSCH, 2016, p. 2).

127 Os curadores Moacir dos Anjos e Agnaldo Farias na 29a Bienal de São Paulo , concebem para ocupação do enorme pavilhão do Ibirapuera um espaço de exposição intercalado por respiros nomeados de terreiros a partir do samba Brasil, pandeiro (1940), de Assis Valente. "Transpostos e adaptados para o ambiente expositivo, os terreiros desempenham seu papel como lugar de encontro, fala, escuta, disputa, comunhão, e dúvida, ecoando a potência da política como ato de criação do que não é dado, ou do que sequer se adivinha possível” (FARIAS; DOS ANJOS, 2010, p. 27). 
retroalimentava a plataforma, com a inserção de novos excertos reflexivos captados durante essas performances, estabelecendo uma continuidade da luta política entre o espaço e os públicos da bienal, e sua implicação direta com a cidade.

Ainda como efeito desse entrecruzamento, o projeto Sem título (Nova Luz, mas poderia se chamar Porto Maravilha - 2013) <imagem C2.9 p.152> responde ao convite endereçado à Usina para integrar a exposição de inauguração do Museu de Arte do Rio (MAR), O Abrigo e o terreno: arte e sociedade no Brasil (2013). A curadoria de Paulo Herkenhoff e Clarissa Diniz propunha como marco inicial das atividades do MAR uma investigação crítica sobre a Praça Mauá128 e os conflitos apagados pela operação urbana que deu origem ao museu como uma das "âncoras” da reurbanização. $\mathrm{O}$ trabalho desenvolvido e apresentado pela equipe coordenada por Kunsch contraria a demanda de exibir grandes fotos do acervo histórico da Usina ao propor uma investigação específica para esse contexto, adotando a estratégia de elaborar uma exposição dentro da exposição e, assim, aguçar a percepção do público sobre o modus operandi das intervenções urbanas e seus efeitos nas cidades brasileiras, sejam elas São Paulo, Recife, Fortaleza ou Rio de Janeiro.

Pode-se afirmar que essa transposição para o contexto da arte, com seus modos de experimentação estética com públicos diversos e não especializados, cria uma segunda camada, ou um novo contexto participativo. Um contexto que "reflete essa heterogeneidade estrutural e os múltiplos sites e formas de intercâmbio através dos quais a arquitetura opera” (SCOTT, 2012, p. 65, tradução minha) ${ }^{129}$, investindo na problematização das relações de força, no debate público e nas disputas narrativas em curso nas cidades. Uma plataforma

A transformação urbana da Praça Mauá integrou o projeto do Porto Maravilha (2009-2016), que transformou a região portuária do Rio de Janeiro com obras monumentais que incluíram a demolição da Perimetral, via elevada de $7 \mathrm{~km}$, a construção de $4 \mathrm{~km}$ de túneis escavados sob sítios históricos, com alto impacto sobre o patrimônio simbólico, ambiental e social da região. Para mais, consultar a pesquisa coordenada por Ana Luiza Nobre no Departamento de Arquitetura e Urbanismo da Pontifícia Universidade Católica do Rio de Janeiro. Plataforma RioNow (2009-2016). Disponível em: http://rionow.org/home.html. Acesso em: 11 out. 2019.

129 No original: "[...]to reflect this structural heterogeneity and the multiple sites and formats of exchange throught wich architecture operates." 
para repensar radicalmente as paisagens urbanas de poder dentro das quais a arquitetura opera.

Ainda segundo Scott (2012, p. 66):

De fato, exposições (e eventos e publicações relacionados) têm sido um local produtivo e visível de prática crítica e experimental em arquitetura; eles têm sido fundamentais para abrir novas linhas de pesquisa, testar novos formatos, tecnologias e investigações programáticas, e lançar novas polêmicas e reivindicações conceituais sobre para onde a arquitetura pode estar indo. ${ }^{130}$

Essa prática crítica e experimental em arquitetura, que desloca o pensamento arquitetônico para outros lugares de ação, agindo também sobre suas formas de visibilidade, configura uma "prática estética" nos termos elaborados por Rancière. Nesse sentido, conforme o filósofo, não se trata de uma oposição entre o desencantamento pós-moderno acerca do fim das utopias e possíveis respostas vanguardistas por parte da arte, mas, sim, uma elaboração sobre as “[...] 'maneiras de fazer' que intervêm na distribuição geral das maneiras de fazer e nas suas relações com as maneiras de ser e formas de visibilidade" (RANCIÊRE, 2005, p.17, grifo do original). Ou seja, como instâncias articuladas, pensar, fazer e visibilizar definem uma estética política, "como formas de inscrição do sentido da comunidade” (RANCIÈRE, 2005, p.18), seja "pelos tipos de inserção social dos artistas ou o modo como as formas artísticas refletem estruturas ou movimentos sociais" (RANCIÈRE, 2005, p. 19).

Guardadas as especificidades e diferenças entre contextos, os processos gestados pelos movimentos de moradia e assessorias técnicas em São Paulo, assim como A utopia realizável de Friedman, ensaiada na França, ou os recentes experimentos lationamericanos, possibilitam um alto grau de partilha das responsabilidades entre as partes implicadas em diversas etapas dos processos de transformação

$130 \quad$ No original: "Indeed, exhibitions (and related events and publications) have been a productive an visible site of critical and experimental practice in architecture; they have been central to opening new lines of research, testing new formats, technologies, and programmatic investigations, and lauching new polemics and conceptual claims for where architecture might head". 
espacial, considerando o envolvimento dos futuros usuários no fortalecimento do comum.

Seja na concepção, gestão ou construção, os diversos processos aqui analisados configuram um potente espaço social, e dessa forma, estabelecem uma ruptura que expõe as dificuldades para a implantação de tais sistemas, uma vez que perturbam os interesses políticos, econômicos e de controle onde se inserem. Práticas em consonância com as questões tratadas por Jane Rendell, em seu livro Art and Architecture. A place between (2008), ao lançar a questão:

"Onde estão os lugares que os arquitetos devem investigar e inventar para criticar os sistemas dentro dos quais operam?” (RENDELL, 2006, p. 37, tradução minha).

É sintomático, portanto, que nos últimos dez anos o trabalho de Yona Friedman tenha sido revisitado. Sua produção múltipla, que se desloca também para o campo discursivo - no qual elaborou de forma mais completa seu pensamento sobre sistemas abertos à participação -, estabelece uma importante interlocução com o debate arquitetônico contemporâneo, abrindo o projeto como sistema de organização e troca de informação para a construção ou para outras intervenções possíveis que tenham impacto real sobre a produção do espaço, como em sua hipótese de governança publicada como livro, onde elabora meios para transferir para os cidadãos a real gerência sobre a produção do espaço, e evoca outros campos de ação com novas ferramentas e procedimentos necessários para uma contribuição à prática de arquitetura.

Retomando Aureli e Orazi, há uma coerência no projeto de Friedman, e no modo como aborda o projeto "como um formato conceitual no qual a relação entre pensamento e forma, intenção e artifício, tema e contexto, é sempre esclarecida e pertinente a problemas e questões específicas que designamos como urgentes" (2006, p. 25, tradução minha $\left.{ }^{131}\right)$. Ou seja, são modos de intervenção em "circuitos ideológicos” para o enfrentamento das condições da vida urbana, sem os quais condições emergenciais permanecerão sem resposta, ao menos por parte dos arquitetos.

No original: "project must be seen as a conceptual format in which the relationship between thought and form, intention and device, theme and context, is always made clear and pertinent to specific prob- lems and issues that we designate as urgent". 


\section{Projetos deslocados}

A pergunta retórica de Rendell, sobre os lugares inventados para a crítica dos sistemas nos quais os arquitetos operam, contém um olhar interno à própria disciplina com evidente teor de crítica institucional. Algo que se complexifica diante de um cenário de distensões da prática e de um momento no qual a arquitetura faz uma revisão de seus compromissos sociais e políticos.

A argumentação de Jacques Rancière sobre uma prática estética e política, que articula fazer, pensar e visibilizar, contribui para esse debate quando transposta para um exame de sua aplicabilidade à arquitetura. Foi o que aconteceu durante um seminário realizado, no final de 2019, na Faculdade de Arquitetura Cooper Union, em Nova Iorque, envolvendo um diálogo entre o filósofo e teóricos da arquitetura $^{132}$, que endereçou a seguinte pergunta: como a arquitetura pode distribuir o sensível?

Dentre as diferentes análises e interpretações produzidas por esse debate, a resposta de Rancière aponta para um paradoxo disciplinar, dado que a arquitetura, por estar atrelada à produção de algo para além de si, no mundo real, com fins específicos e determinados por um poder externo, faz com que seja, dentre as artes, aquela em que um processo de "desidentificação"133 torna-se mais

132 O seminário Architecture Exchange - Jacques Rancière: How Architecture Distribute the Sensible, que aconteceu em novembro de 2019, contou com contribuições de Peggy Deamer, Anthony Vidler, Michael Young e Joan Ockman, além do próprio filósofo. Cada autor escreveu um artigo sobre suas leituras de Rancière, que na sequência comentou as diversas interpretações e apresentou sua resposta à pergunta tema. Disponível em: https://architecture. exchange/exchange/ranciere/. Acesso em: 18 jan. 2020.

133 Desidentificação no pensamento de Rancière significa uma subjetivação política, um afastamento de definições impostas de limites à participação no comum. Em sua reflexão sobre política, Rancière presume uma interlocução entre sujeitos e a exposição de seus mundos para que se elaborem reconfigurações, uma vez que o comum pressupõe reconstrução constante. Assim, a ação política pode ser abordada por meio da criação de uma cena dissensual que questione as linhas de divisão entre 
complicado. Isso, segundo o autor, implica o reconhecimento de uma distinção entre arquitetura e edificação para que se ressalte a importância da arquitetura para além de um papel na distribuição material - de espaços físicos e atividades humanas - e sua importância num campo subjetivo e simbólico no qual se possam formular reconfigurações do espaço comum.

Assim, para Rancière, é ao se aproximar da arte, como nas imagens e colagens propostas pelo grupo inglês Archigram, que a arquitetura melhor tangencia sua interpretação sobre uma possível distribuição do sensível. Ao assumir diversas formas e produzir imagens, textos e especulações sobre espaços, suspendendo finalidades e hierarquias para distribuir igualdade e liberdade, a arquitetura talvez possa reconfigurar o comum justamente por não construir nada ${ }^{134}$ (RANCIÈRE, 2019, vídeo online).

Mas, desde que Filippo Brunneleschi assume a cisão entre os tempos e lugares da produção arquitetônica - ao representar e antecipar a solução construtiva da cúpula da Catedral de Santa Maria del Fiore no século XV - configurase uma nítida distinção entre o momento da produção intelectual projetada e o canteiro de obras como estágio do saber manual que a executa. Desde então, a arquitetura recorre ao projeto como lugar de uma formulação gráfica e mental, como território especulativo ${ }^{135}$, sendo essa inclusive

igual e desigual, o que implica numa “desidentificação desses sujeitos com relação ao estatuto que lhes é institucionalmente e culturalmente atribuído" (MARQUES; LELO, 2014, p. 58).

134 Rancière ressalta que a história da arquitetura, segundo Hegel, começa justamente com a Babel, um edifício impossível de ser construído, e segue destacando o sentido de progresso técnico que a impulsiona como disciplina. Assim, ainda que edifícios sejam parte da construção do sensível, o filósofo destaca que são também elementos responsáveis pela construção de divisões e separações, e indica caminhos para a arquitetura redistribuir o sensível a partir da construção de continuidades e de mobilidade rumo a uma civilização que não separe arte e vida, passividade e atividade, trabalho e gozo. Tais especulações surgem com maior veemência em projetos nunca construídos, como no exemplo citado pelo filósofo da proposta do OMA para o concurso da biblioteca Nacional da França, Jussieu - Two Libraries (1992).

135 Basta pensar em como, no passado, diversos arquitetos como Giovanni Battista Piranesi com sua série de Cárceres Imaginários (1745-50), Etienne Louis Boullée com o Cenotáfio de Newton(1784) e Antonio Sant'Elia com a Cittá-Nuova (1914), experimentaram desenhos arquitetônicos como meio de investigação e produção de um discurso arquitetônico. 
a grande matriz na qual se pauta o ensino da disciplina.

A relação entre imaginado e real mobilizada pelo projeto arquitetônico representa, portanto, um amplo espectro de concepções na qual os desenhos normalmente utilizados para descrever a construção projetada são apropriados como código para a comunicação de especulações conceituais com potencial crítico ou utópico, sem um necessário desdobramento físico no mundo.

Recentemente, a produção de projetos utópicos, ou mesmo distópicos, vem sendo reportada ao termo "arquitetura de papel" [paper architecture] ${ }^{136}$, uma interpretação que assume muitas vezes um tom pejorativo e que diminui a relevância dessas investigações gráficas ficcionais, na medida em que as circunscrevem a uma atividade marginal, não levando em conta seu papel de subversão conceitual em momentos de revisão disciplinar.

O recuo estratégico deste tipo de proposta não significa uma rejeição da arquitetura, mas um enfoque sobre a natureza da disciplina que, por meio da produção de projetos como imagens autocríticas, direcionam um exame acerca da positividade representada pela associação da arquitetura às forças instáveis que a sustentam e a viabilizam, como nos ensaios em que novos modos de vida e a contracultura informavam a criação de espaços abertos, nômades e possíveis de serem modificados por seus usuários, em projetos radicalmente ${ }^{137}$ conceituais do final dos anos

136 O termo paper architects foi empregado por um grupo de jovens arquitetos russos dissidentes que, na década de 1980, assumiram uma postura crítica ao não se submeterem à rígida cartilha de padronização estética do governo soviético, que resultava em edifícios burocráticos, erguidos de maneira barata e rápida, com baixa qualidade técnica e sem qualquer comprometimento com os futuros usuários e com os espaços urbanos massificados que geravam. Michael Belov, Alexander Brodsky e Ilya Utkin, Mikhail Flippov, Nadia Bronzova e Yuri Avvakumov, entre outros, produziram nesse contexto uma série de projetos visionários e burlaram as restrições da cortina de ferro para participarem de concursos internacionais então proibidos.

137 Pier Vittorio Aureli atenta para o fato de que a classificação “arquitetura radical”, por parte de críticos como Germano Celant, estava em desacordo com as intenções de muitos dos protagonistas de movimentos de arquitetura, arte, design e política nos anos 1970. Tais classificações acabavam por esvaziar seu princípio crítico inicial. Segundo o autor, "comodificadas nas páginas das revistas de arquitetura como mais um gesto de vanguarda, não se tratava mais de uma tentativa de criticar as formas existentes de produção teórica e de construção” (AURELI, 2013, p. 81). 
1960 e início dos anos 1970, produzidos por grupos como os italianos Archizoom e Superstudio, e o inglês Archigram.

O mesmo pode-se dizer de Bernard Tschumi e seu interesse em hibridações com o campo da arte, que resultam em trabalhos como Manhattan Transcrips (1976-1980), e o modo como o arquiteto explorou a linguagem gráfica para ressaltar justamente o que o desenho arquitetônico não consegue apreender, ou seja, os eventos e deslocamentos e, portanto, as disjunções entre o que é idealizado pelo projeto e seu embate com as complexidades do uso diário.

Não é surpreendente, portanto, que Koolhaas, em dado momento, após a repercussão de Nova Iorque Delirante (1978) e da participação de destaque do OMA em exposições e concursos - o que lhe garantiu a fama de promessa da arquitetura holandesa -, tenha manifestado preocupação em ser taxado como um arquiteto do papel, sem que lhe fossem oferecidas reais oportunidades de construir. Na introdução de uma exposição em Amsterdã, em 1980, ele declara:

$\mathrm{Na}$ ausência de comissões específicas, este trabalho pertence à categoria recentemente inventada de “arquitetura de papel". O efeito desse status é ambíguo: a aparente vantagem de uma carreira como arquiteto de papel é um desenvolvimento acelerado. Mais projetos são feitos, mais problemas são abordados e mais temas são examinados do que em uma carreira convencional. Mas existe o perigo de que o desenho se torne uma atividade vicária e a reputação "de papel" de seu criador, no final, atrapalhe a realização. Sua atividade se torna um tipo de fertilizante para a arquitetura 'real'. Nos últimos quatro anos (alarmado com a abundância de projetos "teóricos" - um reservatório quase transbordante de reinvidicações e argumentações não comprovadas), o OMA realizou projetos concretos nos quais suposições anteriores puderam ser testadas. Adeus papel. (KOOLHAAS apud VAN GERREWEY, 2017, p. 99, tradução minha). ${ }^{138}$

No original: "In the absence of specific commissions this work belongs to the recently invented category of " paper architecture'. The effect of this status is ambiguous: the apparent advantage of a career as a paper architect is an accelerated development. More designs are made, so more problems are addressed and more themes are examined than in a conventional career. But the danger exists that drawing becomes a vicarious activity and the 'paper' reputation of its maker in the end stands in the way of realisation. His 
No entanto, esse percurso teórico do início da carreira de Koolhaas representa uma faceta de sua prática nunca abandonada pelo arquiteto, que se tornou um profícuo comentarista da própria obra, assim como figura fundamental a pautar o debate teórico nos últimos 30 anos por meio de um amplo repertório de análises de fenômenos urbanos, ou como ele próprio coloca: "investimento em olhar, mais do que em fazer" (KOOLHAAS apud EISENMAN, 2013, p.61). Assim, num constante trânsito entre teoria e prática, Koolhaas mobiliza a pesquisa e a escrita como um "sítio arquitetônico para a invenção vitalícia” (STEELE apud EISENMAN, 2013, p.177).

Nesse sentido, o trabalho de um arquiteto como John Hejduk pode ser tomado como referência de um movimento estratégico para a constituição de um lugar deslocado da prática arquitetônica, no qual o projeto configura um campo de criação empregando princípios relacionados à prática projetual.

Os projetos edificados de Hejduk, conquanto existam ${ }^{139}$, acabaram ofuscados pela importância da sua atuação no ensino e por uma produção discursiva que entrelaçava desenhos de edifícios - com grau de detalhamento suficiente para que fossem construídos - e poesia como estratégias projetuais fantásticas, intervindo na estrutura institucional da disciplina ao submeter suas propostas em concursos, importante circuito de publicização e legitimação do pensamento arquitetônico. Este é o caso de Berlin Masque (1981) e de Victims (1983) <imagem C2.10 p.153>, ambos desenvolvidos para a Internationale Bauausstellung (IBA) - um projeto de renovação urbana do governo alemão para a então Berlim Ocidental.

Tais exemplos evidenciam que arquitetura invariavelmente recorre a uma reflexão teórica formulada por meio de projetos deslocados de sua finalidade voltada à edificação para constituir um campo reflexivo interno à disciplina.

Portanto, seria necessário compreender um sentido

activity becomes a kind of fertiliser for 'real' architecture. The past four years (alarmed by the abundance of 'theoretical' projects - an almost overflowing reservoir of unproven claims and pretensions) OMA has taken to concrete projects in which previous assumptions can be tested. Goodbye paper!"

139 Alguns exemplos são o projeto de renovação do edifício da Cooper Union (1975), as Torres de Kreuzberg (1988), em Berlim, ou a Wall House II, um projeto de 1973 que foi executado somente em 2001 como parte de um projeto maior de urbanização desenvolvido por Daniel Libeskind, financiado por uma empresa de desenvolvimento imobiliário na cidade de Groningen, na Holanda. 
ampliado e multifacetado da produção contemporânea capaz de abarcar atividades e manifestações da prática que envolvam não apenas a arquitetura como forma construída, mas todos os veículos de disseminação e discursos como "sítios constitutivos do conhecimento e prática em arquitetura” (SCOTT, 2010, p.67, tradução minha) ${ }^{140}$, o que inclui "seus artefatos e veículos de divulgação, seus discursos e polêmicas, suas molduras institucionais e pedagógicas, seus modos de produção e representação" (SCOTT, 2010, p.65, tradução minha $)^{141}$. É essa abrangência que envolve todas as maneiras como pensamos e comunicamos a prática ${ }^{142}$ que Felicity Scott nomeia de "plataformas operacionais", no texto onde discute a necessidade de abordagem desses conteúdos em um curso coordenado por ela na Universidade de Columbia.

É importante compreender que essas propostas discursivas não representam exclusivamente um mecanismo de distanciamento impessoal ou de afirmação autorreferente, pretendendo uma autonomia descolada da realidade. Há, em casos exemplares desse tipo de projeto deslocado, um comprometimento com questões urgentes, como colocam Aureli e Orazi (2006) ao se referirem à coerência da obra de Yona Friedman,

[...] cuja pesquisa é exemplar da constituição de um projeto: reação ao senso comum, pesquisa empírica, realização do irreal por meio de um dispositivo teórico tangível e, finalmente, projetação. Acreditamos que o projeto de Friedman pode ser visto como uma resposta à ansiedade pós-crítica de emancipar o pensamento arquitetônico e urbano de sua dimensão crítica imanente. (AURELI; ORAZI, 2006, p. 25, tradução minha). ${ }^{143}$

No original: "[...] constitutive sites of architectural expertise and practice". No original: "Indeed, the vitality and diversity of what we appreciate as "architecture" - its artifacts and vehicles of dissiminaton, its discoureses and plemics, its institutional and pedagogical frameworks, its modes of production and representation".

Scott menciona que essa questão já estava claramente enunciada por Beatriz Colomina no texto de introdução do livro Architectureproduction (1998).

No original: "One example of a project with a coherent intellectual path is that of Yona Friedman, whose research is exemplary of the constitution of a project: reaction to 
Ou seja, Friedman desenvolve uma linguagem na qual a representação arquitetônica, seus desenhos simples e comunicativos, assim como a escrita, são recursos para uma reconfiguração do comum como sugerido por Rancière, em que signos e imagens são rearranjados para construírem ficções que relacionam o que é visto e o que é dito, instaurando um intervalo entre o que é feito e o que pode ser feito. Do mesmo modo, na medida em que os projetos se desdobram em processos e práticas espaciais mais complexas - como demonstram os exemplos citados ao longo deste capítulo e apresentados no caderno de imagens 2 a seguir -, novas atribuições e sentidos são demandados da representação arquitetônica. Isso resulta numa espécie de inversão da ordem sedimentada pelo protocolo profissional, na qual o projeto antecipa e presume os termos de sua execução. As instâncias de comunicação da prática, que envolvem diálogos processuais, levantamento e análise de dados, mapeamentos - muitas vezes realizados de modo coletivo -, registros e relatos de intervenções e situações, produzem um choque entre as temporalidades da produção: de um lado, a abstração do espaço projetado, de outro, o espaço vivenciado.

Portanto, esses projetos deslocados endereçam conteúdos claramente críticos e propositivos, mobilizando estratégias de representação e comunicação da arquitetura como um não-sítio de investigação de seus processos de produção no qual a representação arquitetônica torna-se um importante campo de reflexão, mas também de ação, promovendo um deslocamento análogo à dialética entre "site" e "non-site" na obra do artista Robert Smithson.

\section{A dialética sitio e não-sitio}

Não é casual, portanto, que o interesse do artista Robert Smithson pela arquitetura e pela linguagem arquitetônica como modo de subverter noções de representação pictórica, como a perspectiva ${ }^{144}$-, a partir dos anos 1960, o tenha

common belief, empirical research, making unreal by means of a tangible theoretical device, and finally, projection. We believe that Friedman's project can be seen as an answer to the postcritical anxiety to emancipate architectural and urban thinking from its immanent critical dimension”.

144 Segundo Mark Linder autor de Nothing Less than Literal. Architecture after the Mininmalism (2004) Smithson procurava negar a noção de 
conduzido a desenvolver o não-sítio como lugar deslocado de suas intervenções na paisagem, mas também como um modo de exercer uma crítica arquitetônica "que não é apenas sobre arquitetura, mas é implicitamente arquitetônica em sua mídia, seu conteúdo, sua implantação e sua forma” (LINDER, 2004a, p.146).

À medida que seu trabalho conquistava uma expressão tridimensional, destacando-se das superfícies planas - na forma de estruturas que remetem a cristais de acrílico e espelho - e desencadeando rebatimentos múltiplos da galeria que deslocavam o olhar do objeto para a periferia do espaço expositivo, sua escrita, como um meio essencial à sua manifestação artística, abordava a arquitetura e remetia ao ambiente dos subúrbios e à arquitetura das obras de ficção científica $^{145}$. Nesse período de maturação de seu trabalho, Smithson é convidado a integrar como artista-consultor a equipe encarregada de projetar o novo aeroporto de Dallas ${ }^{146}$.

Segundo críticos e analistas de sua obra, essa experiência ${ }^{147}$ foi determinante para que Smithson iniciasse seus "earthworks" 148 e se direcionasse para as intervenções de grande escala na paisagem que culminaram em seu mais

janela pictórica como a abstração proposta por Alberti, assim como a planaridade defendida por Greenberg por considerá-las “invenções formalistas do espaço pictórico”. (LINDER, 2004, p. 133-167).

145 Como no texto Entropy and the New Monuments (1966), no qual Smithson se refere a uma arquitetura presente nas ficções científicas que sugere um novo tipo de monumentalidade que era encontrada de modo semelhante na arte daquele período, nomeadamente o minimalismo, que segundo ele produzia uma analogia visível do princípio da entropia, nos demonstrando que é mais fácil perder do que obter energia. Do mesmo modo, a desvirtuada arquitetura da Park Avenue, em Nova Iorque, com suas caixas de vidro geladas, ou a modernidade maneirista de Phillip Johnson, teriam também atingindo um caráter entrópico (SMITHSON apud FLAM, 1996, p.10).

"Um contrato de um ano a partir de julho de 1966 como arista consultor na firma Tippetts-Abett-MacCarthy-Stratton, Engineers and Architects (TAMS), que foi responsável pelo plano inicial de implantação e pelo projeto do novo Dallas-Fort Worth Regional Airport, uma colaboração esporádica que incluía consultoria e visitas ocasionais ao site”. (LINDER, 2004b, p. 189).

147 "Mais importante, Smithson chegou a essa reconfiguração do formalismo por meio de um compromisso com a arquitetura, uma mudança transdisciplinar que tem sido amplamente negligenciada nas inúmeras narrativas sobre seu trabalho" (LINDER, 2004b, p. 189).

148 Earthwork pode ser traduzido como terraplanagem, que adquire um sentido técnico específico, sendo mais comum a sua disseminação no original em inglês quando relacionada à vertente da produção artística associada à landart. 
conhecido trabalho, Spiral Jetty (1970). É também durante suas visitas de campo ao canteiro de obras, assistindo às escavações, e a análise dos mapas e planos de implantação do aeroporto, que ele primeiro sugere a relação entre sítio e não-sítio:

Eu estava interessado em capturar a sensação de expansão e distanciamento fora do espaço da sala. A experiência do meu trabalho tinha que ocorrer tanto em ambientes internos quanto externos. Fiquei interessado em movimentos de terra como resultado do projeto do aeroporto. Os não-sítios surgiram como resultado do meu pensamento em realizar terraplanagens em larga escala na borda do campo de pouso e depois pensei: como posso transmitir isso para o centro? (SMITHSON apud LINDER, 2004, p. 139 , tradução minha) $)^{149}$.

Smithson chega a pensar em um circuito de câmeras para transmitir os movimentos de terra para o interior do terminal do aeroporto, mas seu interesse aos poucos se desvia do edifício para o processo de sua elaboração e, mesmo após se desligar da equipe de projeto do aeroporto, continua a desenvolver seu argumento numa sequência de trabalhos exibidos em galerias ao longo de 1968, os NonSites <imagem C2.11 p.154>. Nessas instalações, Smithson desenvolve o conceito do não-sítio combinando múltiplos meios de representação, como mapas, fotografias, textos descritivos e extrações de amostras do local, para apresentar os espaços dos sítios reais.

Desse modo, ele explora a materialidade, a representação e os registros do sítio como elementos organizados numa composição tridimensional esquemática que estabelece conexões mais abstratas entre o interior e o exterior da galeria, sem empregar representações pictóricas. Não há uma hierarquia entre os elementos expostos, pois todos os elementos operam conjuntamente para descrever o sítio, mas também para, a partir dele, abrir outras interpretações

149 No original: "I was interested in capturing the sense of expanse and remotness outside of the room space. The expirience of my work had to take place both indoors and outdoors. I got interested in the earthworks as a result of that airport project. The non-sites came as a result of my thinking about putting large-scale earthworks out on the edge of the airfield, and then I though, how can I transmit that to the center?" 
especulativas que borram os limites entre o ficcional e o real, conjurando um mundo onde estas instâncias se sobrepõem.

Igualmente relevantes para essa elaboração são os textos A Provisional Theory of Non-Sites (1968) e Sedimentation of the Mind (1968), ou mesmo a nota que acompanha seu texto The Spiral Jetty (1972), na qual Smithson desenvolve e apura a relação dialética entre sítios e não-sítios como uma oposição entre limites abertos e fechados, subtração e adição, reflexão e espelho, borda e centro, dispersão e concentração de informação, físico e abstrato. Segundo o artista:

O alcance da convergência entre o Sítio e o NãoSítio consiste em um percurso de acasos - um caminho duplo composto por signos, fotografias e mapas que pertencem a ambos os lados da dialética de uma só vez. Ambos os lados estão presentes e ausentes ao mesmo tempo. A terra ou o terreno do sítio é colocado na arte (não-sítio) ao invés da arte ser colocada no terreno. O não-sítio é um contêiner dentro de outro contêiner - a sala. Coisas bidimensionais e tridimensionais trocam de lugar entre si na faixa de convergência. [...] As regras dessa rede de signos são descobertas na medida em que você percorre trilhas incertas, tanto mentais quanto físicas. (SMITHSON apud FLAM, 1996, p.153, tradução minha). ${ }^{150}$

Como se vê, para Smithson não se tratava de uma simples transferência de informações de um local para outro, mas de rebatimentos possíveis entre o sítio como obra e o não-sítio como seu campo discursivo e de documentação, insinuando uma troca constante de sinais entre o concreto e o metafórico. Ou como sugere o artista, “o non-site passa a ser o centro do sistema e o próprio site a periferia ou a

No original: "The range of convergence between Site and Nonsite consists of a course of hazards, a double path made up by signs, photographs, and maps that belong to both sides of the dialectic at once. Both sides are present and absent at the same time. The land or ground from the Site is placed in the art (nonsite) rather than the art placed on the ground. The Nonsite is a container within another container- the room. Two-dimensional and threedimentional things trade places with each other in the range of convergence. [...] The rules of this network of signs are discovered as you go along uncertain trails both mental and physical." 
extremidade" (SMITHSON, apud FERREIRA; COTRIM, 2006, p.285).

Esse questionamento sobre onde está o centro do trabalho revela justamente o complexo fluxo que Smithson propõe, conectando ambas as instâncias de criação, aquela do objeto em sua materialidade e aquela dos processos subjetivos e camadas de informação e representação tanto prévias quanto posteriores a sua realização. Ou seja, tempo e espaço ganham uma dimensão além do que se pode perceber pela presença física, uma vez que representação e construção se embaralham.

Com esse procedimento, Smithson estabelece um significativo ponto de inflexão no debate artístico do final dos anos 1960, do qual dois pontos podem ser destacados. Em primeiro, o artista instaura uma prática movediça a partir de sua saída do estúdio rumo ao mundo, em busca de novos sítios à margem do sistema econômico e de legitimação do sistema de arte, o que direciona seu olhar tanto para a perifieria do sistema quanto para a porosidade discursiva e crítica, manifesta com rigor na formalzição de seus trabalhos e textos. Em segundo, ele manipula diversos meios de expressão, como a escrita, a documentação fotográfica e videográfica e as instalações, onde reúne subjetivamente artefatos e informações, privelegiando a discursividade.

Portanto, transpor o não-sítio para o pensamento arquitetônico, como um campo para exploração do papel conceitual e crítico da arquitetura, de acordo com a proposição de Jane Rendell, não significa admitir que desenhos processuais para elaboração de um projeto necessariamente configurem um não-sítio, o que significaria uma simplificação de sua proposição.

Trata-se de uma sofisticada provocação para o campo arquitetônico em sua aderência demasiada ao sitespecific fenomenológico. A proposição de Rendell pode significar uma revisão da representação arquitetônica como elemento imbricado à construção, ao mesmo tempo em que é elemento constituinte do espaço vivenciado - tanto quanto as camadas existentes e não percebidas, os processos de apagamentos, os projetos não realizados e as ficções possíveis. Pensar o não-sítio e sua transposiçõ para o campo arquitetônico pode, portanto, sugerir uma nítida ampliação do escopo destinado à representação arquitetônica, que pode assumir novos sentidos ao revelar e orientar operações 
possíveis.

Do mesmo modo, tal transposição conceitual não quer dizer que o crescente fenômeno de bienais de arquitetura pelo mundo constitua não-sítios da prática arquitetônica per se, como deslocamentos discursivos para o ambiente expositivo. Também, não garante que molduras pedagógicas e acadêmicas configurem necessariamente esse espaço. No entanto, a proposta de Rendell nos alerta sobre a necessidade de se examinar como essas "plataformas operacionais" são mobilizadas pela arquitetura e como podem configurar novas práticas e deslocamentos do ato de projetar.

Um caso excepcional, no qual todas essas plataformas se cruzam, ampliando o entendimento sobre como a arquitetura oferece perspectivas de reconfiguração desde um campo discursivo com rebatimentos práticos e concretos, é a atuação do grupo multidisciplinar Forensic Architecture, baseado no Goldsmiths College ${ }^{151}$ da Universidade de Londres e coordenado pelo arquiteto Eyal Weizman.

O Forensic Architecture parte de situações reais para realizar investigações espaciais que empregam diversas mídias, meios de representação e tecnologias para a reconstrução virtual de espaços e situações nas quais ocorrem casos de violação de direitos humanos. O grupo trabalha em proveito de causas comunitárias ou agindo diretamente nas comunidades afetadas por violência, estabelecendo redes de apoio e troca com organizações de direitos humanos, órgãos internacionais de justiça, grupos que atuam em causas ambientais e organizações de mídia independente para constituírem, segundo o próprio grupo ${ }^{152}$, um campo acadêmico emergente, a “arquitetura forense”.

O termo forense, que em sua raiz originária do latim quer dizer tudo que pertence ao fórum, é normalmente

Eyal Weizman é professor de culturas espaciais e visuais no Goldsmiths College que, embora não ofereça um curso de Arquitetura e Urbanismo, possui tradição em pesquisas interdisciplinares baseada em sua matriz acadêmica voltada para as humanidades nas áreas de artes, ciências sociais, estudos culturais, computação e administração, favorecendo a hospedagem de uma plataforma de pesquisa inovadora, cujo campo de atuação é elaborado na medida em que o grupo se desenvolve e molda seu contexto de atuação.

Definição baseada nos textos que compõem o livro Forensis: The Architecture of Public Truth e nas informações disponibilizadas pelo grupo em sua plataforma on-line disponível em: https:// forensic-architecture.org/about/agency. Acesso em: 7 jan. 2019. 
associado à aplicação da ciência a casos levados aos tribunais de justiça, mas, segundo Weizman, esse é um desvio linguístico do sentido original do fórum romano como espaço político constituído por múltiplos aspectos. Ambos os sentidos informam a prática crítica do grupo que produz investigações paralelas e independentes das instâncias oficiais, de modo a articular os dois sítios constitutivos da prática forense: o campo, como o espaço que molda e é moldado por situações de conflito, e o fórum, como lugar onde o resultado da investigação é apresentado e debatido, podendo ser contestado. Trata-se, portanto, de tentar transformar o "forense em uma prática contra-hegemônica capaz de inverter a relação entre indivíduos e estados, desafiar e resistir à violência estatal e corporativa e à tirania de suas verdades" (WEIZMAN, 2014, p. 11 , tradução minha $)^{153}$.

Ao contrário do caráter científico das análises forenses convencionais, o grupo se pauta em pesquisas históricas, em práticas artísticas - historicamente próximas às causas de direitos humanos ${ }^{154}$ - e na arquitetura como um campo de conhecimento que possibilita sofisticadas interpretações do espaço.

Em consonância com a formulação lefebvriana do espaço como um fenômeno social simultaneamente produto e agente de sua produção, as análises do Forensic Architecture utilizam a arquitetura como ferramenta tanto por seu papel determinante sobre a produção do espaço quanto pela sua constituição como um sistema de informação que possibilita a leitura e a interpretação de inúmeras camadas subliminares a partir de técnicas de representação do espaço, realizando uma

153 No original: "We were on the other hand committed to the possibilities of reversing the forensic gaze, to ways of turning forensics into a counter hegemonic practice able to invert the relation between individuals and states, to challenge and resist state and corporate violence and the tyranny of their truth".

154 O grupo reconhece a potência dessa aliança pela qual artistas e órgãos de defesa de direitos humanos construíram uma forte relação de sensibilização pública, empregando documentações poéticas. No entanto, por identificarem pontos frágeis nessa colaboração - em casos nos quais explorar imagens significa reafirmar estereótipos, ou por expor de modo ilustrativo situações de violência nas quais o perigo é real e iminente -, procuram se posicionar criticamente diante do material documental a ser publicizado. Por essa razão, dialogam proximamente com instâncias e representantes envolvidos nos casos com os quais se envolvem, atentando para um debate sobre políticas de representação, de modo a marcar uma posição cuidadosa sobre o modo como utilizam meios estéticos como ferramentas de investigação, análise e comunicação. (WEISMAN, 2014) 
espécie de engenharia reversa que reconstrói cenas, edifícios e ambientes urbanos em busca de novas evidências.

As características físicas são documentadas e periciadas por um processo de arqueologia do projeto, em busca de marcas, alterações e deformações, ao mesmo tempo em que camadas de informação subjacentes são cotejadas com a configuração do espaço, oferecendo interpretações intersubjetivas relativas aos protocolos que desencadeiam situações de manipulação e controle espacial com impacto direto sobre indivíduos e comunidades.

Atuando como uma agência autônoma, o Forensic Architecture criou um contexto para sua prática, ocupando um campo estratégico voltado a revelar as contradições implícitas aos sistemas de poder, em meio a um imbricado cruzamento e dissolução de limites entre público e privado no presente cenário global, o que torna mais urgente intervir criticamente na epistemologia forense, de modo a afetar processos políticos e seu impacto sobre corpos e modos de vida.

Além de empregar a linguagem arquitetônica para localizar e interpretar ações de violação de direitos humanos, o Forensic Architecture depende da comunicação de seu trabalho para reverberar as contranarrativas que produz. Em um vídeo de apresentação para a exposição dos indicados ao Prêmio Turner, em $2018^{155}$, Weizman reafirma a importância da exposição como um lugar deslocado da prática e pesquisa do grupo, um espaço estratégico e necessário de inserção dos trabalhos em circuitos de comunicação e publicização de informações para sensibilização da opinião pública.

Cruzando os circuitos da arte e da arquitetura, bem como o regime de produção cultural no qual esses campos se encontram imbricados, o Forensic Architecture exibe seus trabalhos ou produz trabalhos específicos a convite de molduras institucionais que passam também a se posicionar a partir de seus depoimentos curatoriais e dos trabalhos que comissionam, a exemplo dos trabalhos desenvolvidos para a Documenta 14 (2017), ou para a $3^{\circ}$ Bienal de Arquitetura de Chicago ... and Other such Stories (2019) ${ }^{156}<$ imagem C2.12 turner-prize-2018/forensic-architecture. Acesso em: 7 jan. 2019.

156 A última edição da Bienal de Arquitetura de Chicago, com curadoria de Yesomi Umolu, Sepake Angiama e do brasileiro Paulo Tavares, 


\section{p.155>.}

The Murder of Halit Yozgat (2017) foi desenvolvido a convite de uma organização local da cidade de Kassel para a Documenta 14 e reconstitui a cena do assassinato de Halit Yozgat, filho de imigrantes de origem turca assassinado em 2006, em seu internet-café na cidade. A partir da reconstituição da cena do crime, empregando maquetes eletrônicas e a construção de uma instalação em escala $1: 1$, foi possível reconstruir uma linha do tempo que posicionou todas as testemunhas no espaço, reencenando seus deslocamentos ao longo dos $6 \mathrm{~min} 29 \mathrm{~s}$ decisivos na execução dos disparos contra Yozgat. A partir do cruzamento dos registros de login nos computadores e dos depoimentos das testemunhas presentes, três cenários possíveis foram reencenados, comprovando o falso testemunho de um agente de segurança do Estado, presente no local e hora do crime praticado por um grupo neonazista, evidenciando a indiferença na investigação do crime e a provável conivência de autoridades com crimes de ódio no país ${ }^{157}$.

Durante os 100 dias de duração da Documenta, o grupo promoveu e abrigou encontros e debates que articularam diferentes grupos de proteção a imigrantes na Alemanha e movimentos internacionais de direitos humanos no espaço expositivo, onde também foram mostrados vídeos, documentos e a reconstituição acústica dos disparos que o oficial alemão alegava não ter escutado, amplificando as revelações de racismo estrutural e cegueira institucional a partir da instalação em Kassel.

O Forensic Architeture revela, por meio de sua prática, um imbricado entrecruzamento de plataformas operacionais nos quais a arquitetura se reposiciona estrategicamente deslocando sua produção da ortodoxia do projeto. Baseado numa universidade, o grupo realiza pesquisas amparado por

se posicionou de modo a alterar o rumo conservador das primeiras edições da mostra, procurando repensar as paisagens urbanas de poder da celebrada arquitetura da cidade Chicago de modo a deslocar a investigação da mostra para outras narrativas como a origem indígena do território ocupado pela cidade, políticas de segregação racial que historicamente discrimina populações, e o envolvimento de agentes financiadores da própria exposição em violações ambientais e trabalhistas com impacto no território e na história da cidade.

157 O vídeo que documenta toda a reconstituição do crime está disponível em: https://forensic-architecture.org/investigation/ the-murder-of-halit-yozgat. Acesso em: 20 fev. 2020. 
análises transdisciplinares, com emprego de ferramentas e tecnologias sofisticadas para a espacialização de informações, de modo a criar imagens e contranarrativas que são recolocadas em circulação com objetivo de gerar rebatimentos concretos.

Nesse sentido, os trabalhos do Forensic Architecture, aqui apresentados, dizem tanto sobre o grupo quanto sobre o modo como curadorias e molduras institucionais se posicionam estrategicamente e passam a ter um protagonismo na elaboração de um campo discursivo e propositivo da prática, agindo conjuntamente sobre os territórios com os quais esses eventos se relacionam e articulando sítio e não-sítio de modo a gerar rebatimentos concretos entre um e outro. 



\section{Coleção de referências}




\section{C2.1 Praça Lèon Aucoc (1996) Bourdeaux, França Lacaton e Vassal}

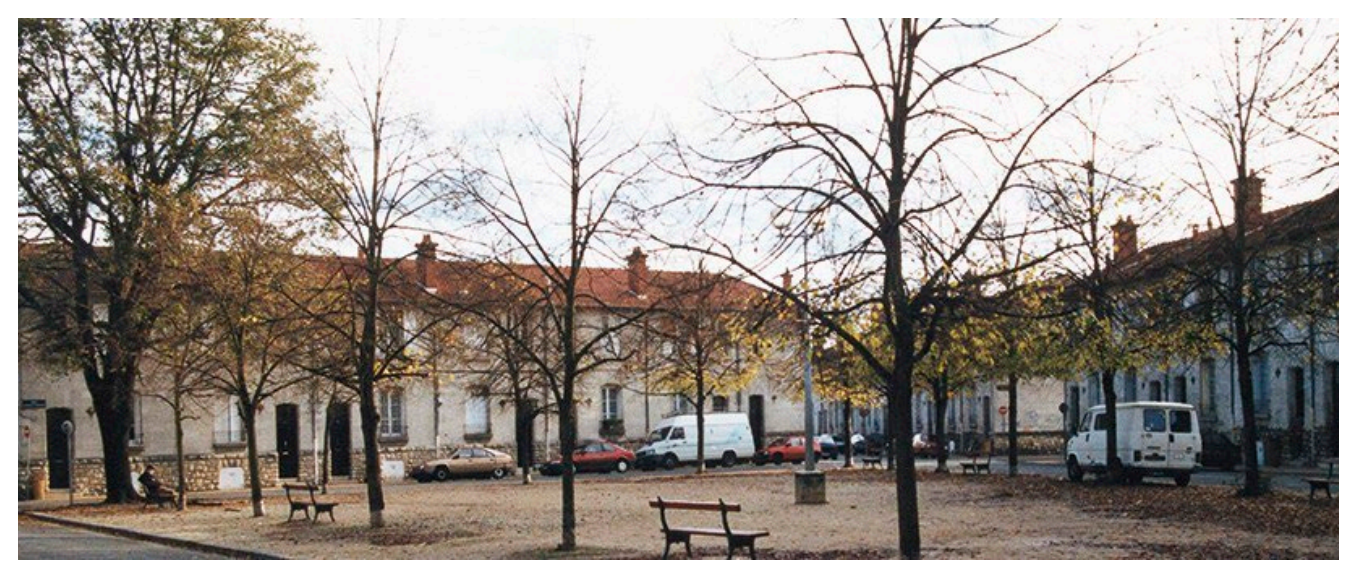

São muitas as possibilidades de análise do procedimento empregado por Lacaton e Vassal no projeto para a pequena praça em Bordeaux, que se tornou um caso emblemático para interpretação do discurso que atravessa e embasa o trabalho da dupla de arquitetos.

Para além da aparente negação que parece abalar alguns princípios consolidados da disciplina arquitetônica, há uma desestabilização das ideologias que determinam seus meios de produção. O principal efeito dessa ação é justamente confundir percepções equivocadas sobre o papel da arquitetura, e destacar sua responsabilidade como inteligência independente da forma, demonstrando que a arquitetura pode se ocupar de não construir, tanto quanto de construir.

O desvio proposto não e , portanto, uma simples recusa da encomenda, ou um projeto não construído, mas um posicionamento afirmativo sobre o reconhecimento do site, com a qualidade de suas soluções cotidianas, a intensidade de seus usos corriqueiros, com elementos convencionais e belos em sua simplicidade. Esse reconhecimento determina um redirecionamento do investimento naquilo que é de fato necessário para a transformação do ambiente vivenciado - neste caso, apenas a sua devida manutenção. O projeto age na reordenação da demanda, distribuindo o orçamento no espaço e no tempo, destacando a existência de alternativas de transformação de uma cidade que não estão condicionadas apenas à implantação de novos edifícios ou às intervenções monumentais, o que pode incluir eventos, o cotidiano, os diversos modos de vida, e uma transformação qualitativa do habitar.

Mas é no deslocamento do projeto da praça para um campo discursivo que se revela a engenhosidade da construção realizada pela dupla. É neste "não sítio" que o efeito de sua ação se amplifica, seja pelo relato escrito e publicado nas principais compilações de seu trabalho, seja nas recorrentes entrevistas em que defendem princípios como simplicidade, baixo custo e baixo impacto das intervenções. Depoimentos sempre acompanhados de imagens intencionalmente despretensiosas - fotos tiradas pelos arquitetos durante suas visitas ao local.

A fotografia do projeto, que não apresenta nenhum objeto construído além do próprio local tal como é, exerce um papel dissociativo fundamental no mercado inflacionando da circulação de projetos-imagens espetaculares. Opera criticamente pela contradição em mostrar uma intervenção invisivel; afinal, como afirma Jean Felipe Vassal (2013, online), "diria que esse projeto já é conhecido e visível. Estamos falando dele agora mesmo". 


\section{C2.2 Intervenções na Vila de Momonoura (2011-) Península de Oshika, Japão Atelier Bow-Wow}
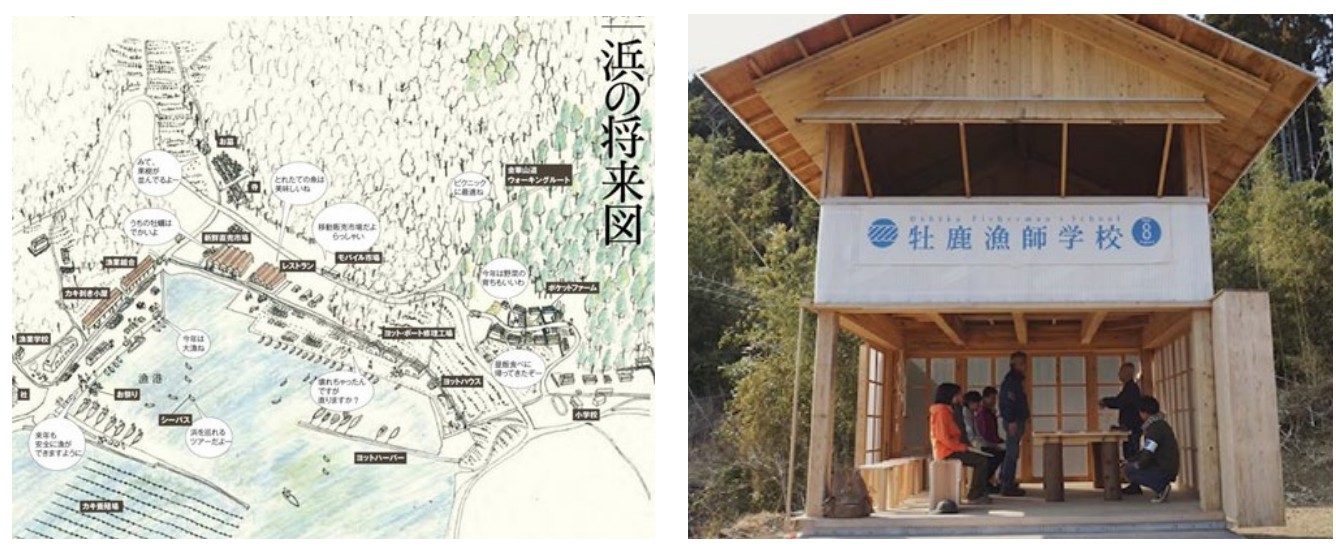

Momonoura é uma vila pesqueira, localizada na península de Oshika, no Japão, devastada pelo tsunami de 2011. Diante das circunstâncias emergenciais, vários escritórios de arquitetura se prontificaram em amparar e assistir as comunidades destruídas criando o ArchiAid.

Para o Atelier Bow-Wow, essa ação implicou um envolvimento de longo prazo com a vila de pescadores, cujos habitantes haviam sido transferidos para abrigos temporários. Para isso, criaram uma equipe envolvendo estudantes universitários e voluntários das brigadas humanitárias, para, em conjunto, mediar, equalizar e compatibilizar as expectativas da comunidade e reuní-las numa proposta alternativa aos projetos apresentados pelo governo que, com suas equipes segmentadas e burocráticas, apresentava respostas imediatistas, como a criação de um dique, a elevação de vias costeiras e a alteração da zona portuária propostas que preocupavam a comunidade.

Um plano diretor foi elaborado coletivamente visando a implantação gradual de diversas intervenções, todas resumidas num mapa com desenhos simples de serem compreendidos. Uma peça de comunicação que poderia ser utilizada por todos, criando uma imagem partilhada e consciente para o futuro da vila.

A nova zona residencial foi criada na parte alta, nas montanhas. Uma vez que a reconstrução era quase total, e duraria quatro anos, transferir a vila era não só factível,

mas desejável, pois gerava um sentido de segurança e reconexão com a floresta.

Os arquitetos agiram em diversas frentes de trabalho. Uma delas foi a construção de um protótipo para um núcleo residencial básico, que considerasse aspectos das tradicionais casas de pescadores locais. $\mathrm{O}$ núcleo inicial podia ser expandido ao longo do tempo, com emprego de técnicas e materiais locais, uma cultura construtiva abandonada a partir dos anos 1980, e da intensificação da préfabricação de componentes de madeira para a indústria da construção civil - para a qual a vila era fornecedora de matéria prima. O protótipo de casa serviu para confirmar a viabilidade de um sistema construtivo misto, aliando peças industrializadas à carpintaria tradicional, ao mesmo tempo em que orientou os habitantes da vila na construção de suas próprias casas.

Como ponto central do projeto, uma escola alternativa foi fundada, não apenas para treinar pescadores, mas para ampliar o intercâmbio entre moradores e equipes externas, intencionando uma troca mútua e fora do sistema acadêmico, de modo a favorecer a recuperação da vila e a sobrevivência e valorização de um modo de vida baseado na pesca.

A escola de pesca, como estratégia de aproximação com o contexto específico de Momonoura, alterou, segundo o BowWow, sua já ampliada visão sobre o potencial de agência da arquitetura como disciplina, a partir de uma prática que denominam de "etnografia arquitetônica". 


\section{C2.3 Broadway Estate Community Garden (2005)}

Tilbury, Inglaterra Muf Art/Architecture
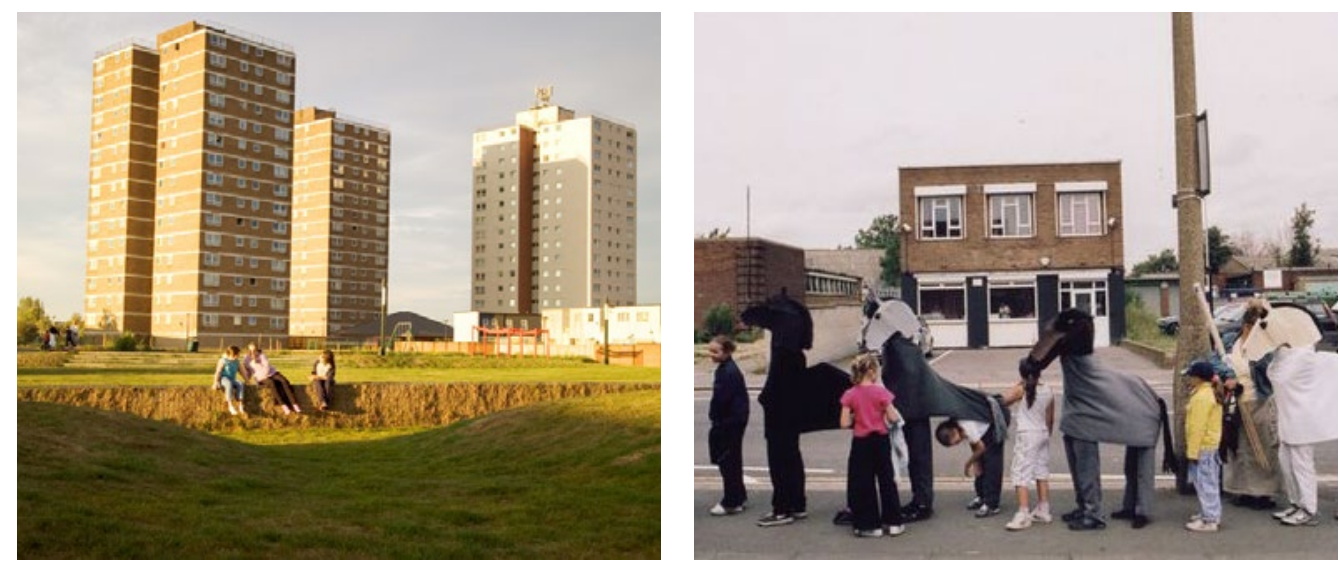

Um jardim comunitário contíguo a densos conjuntos habitacionais tem a sua premissa de encomenda revertida após a constatação de que a área já era utilizada pelos seus moradores.

Antes de responder ao poder público e ao fundo de investimento para desenvolvimento da região, e com isso reiterar procedimentos normativos e tecnocráticos, a intervenção deveria reconhecer e favorecer o valor de uso já existente no local.

Esse projeto integrou a exposição Ações, o que você pode fazer com a cidade (2008-2009), no CCA, e sua remontagem no módulo Modos de Agir da X Bienal de Arquitetura de São Paulo (2013), no Centro Cultural São Paulo.

Com o título de Ação $n^{\circ} 65$ - Cavalos falsos planejam parque de verdade, a exposição destacava o modo proposto para engajar o público - por meio de jogos desenvolvidos com a escola local envolvendo primeiramente as crianças. Afinal, elas poderiam ser os agentes irradiadores de uma campanha para mobilização dos diversos grupos interessados no destino do jardim, identificados após um mapeamento da região pelo Muf.

Os cavalos que pastavam no terreno, cuja presença não era uma casualidade ou reflexo do abandono da área, mas um aspecto celebrado da cultura local, inspiraram brincadeiras com as crianças utilizando fantasias de cavalo confeccionadas por elas como atividade escolar.

Os registros dessa atividade se desdobraram numa campanha com cartazes e um website visando alavancar uma mobilização mais ampla para levantamento das demandas coletivas que pudessem redefinir o programa de necessidades oficial.

Como resultado, o projeto foi simplificado, e contemplou acomodações de terreno com muro gabião, uma cobertura de vegetação rasteira para as áreas destinadas a banhos de sol, um espaço protegido para a instalação de um playground infantil, um picadeiro para passeios a cavalo, além de grandes áreas livres e gramadas com usos não determinados.

As fotos do projeto concluído dizem muito pouco sobre a transformação física do local. A divulgação do projeto e o seu sucesso são compreendidos menos pelas fotografias que documentam o resultado formal, e mais pelos registros das diversas atividades, uma demonstração da importância do processo que, inventivamente, alterou expectativas, mediou e contornou interesses, agregando moradores na tomada de decisões sobre como utilizar o local. Ou seja, ainda que em pequena escala, o projeto foi considerado um êxito de intervenção numa esfera micropolítica, na medida em que investiu de autoridade a comunidade para que decidisse a melhor maneira de destinar a verba pública a ser empregada na transformação da área. 


\section{C2.4. Fun Palace (1960-61) Cedric Price}

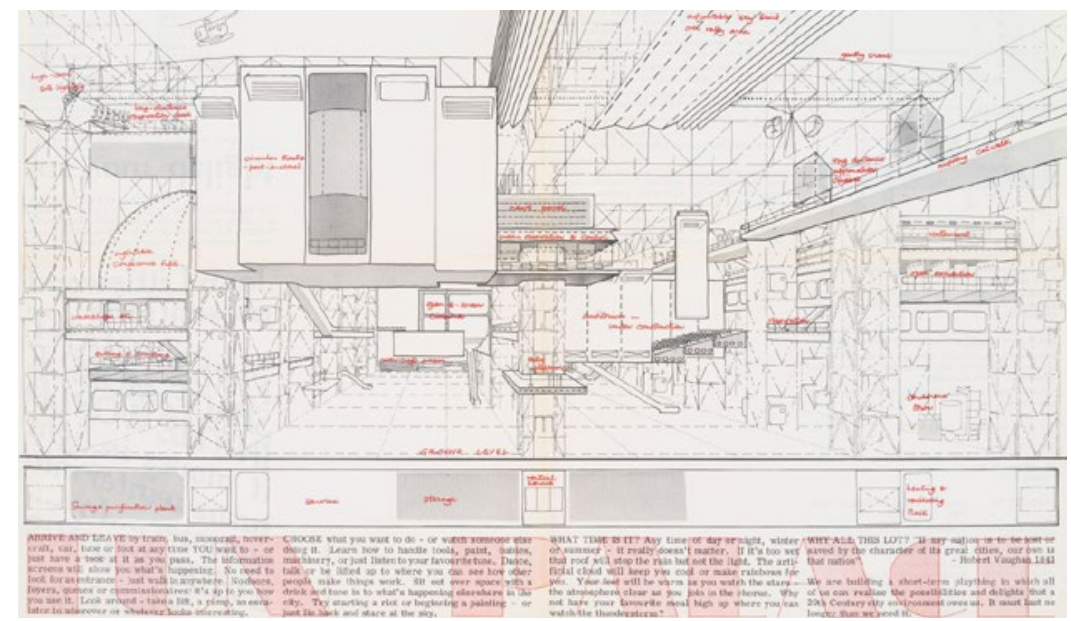

Venha e vá ... ou apenas dê uma olhada. Não é necessário pesquisar a entrada - você pode entrar em qualquer lugar. Sem portas, sem saguão, filas ou balcão de tendimento: tudo está aberto. Assistir, pegar um elevador, uma rampa, uma escada rolante, ir a tudo o que parece interessante.

Escolha o que você quer fazer ou assista a outra pessoa fazê-lo. A qualquer hora do dia ou da noite, inverno ou verão, é a mesma coisa. Se chover, o teto para a chuva, mas não a luz.

Cedric Price

O texto acima integrava o folheto de divulgação para angariar fundos para a construção do projeto Fun Palace, um edifício interativo e maleável, que pudesse ser montado, modificado, desmontado, deslocado e remontado em terrenos públicos em desuso.

Desenvolvido pelo arquiteto inglês Cedric Price, a convite de Joan Littlewood, uma produtora de teatro de vanguarda que havia desenvolvido o conceito para criação de um espaço que pudesse animar o ambiente londrino, que passava por um período de ressaca com a política de austeridade do pós-guerra, o desemprego e a falta de perspectivas que afetava as novas gerações acometidas pelo avanço da cultura de massa.

A dupla interage no desenvolvimento do conceito e da espacialidade simultaneamente, um informando e corrigindo os rumos do outro, partindo de um hibridismo e um programa indeterminado que, embora pressuponha atividades de ensino e a realização de espetáculos, não seria nem uma universidade nem um teatro. O Fun Palace deveria ser um espaço flexível, acessivel, com atividades que promovessem o envolvimento ativo de seus participantes.

Price se encarregava do desenvolvimento do projeto, assim como das peças gráficas de sua divulgação, produzindo desenhos comunicativos informados pelos quadrinhos que admirava. Utilizou diversos tipos de desenho, colagens e modelos para ensaiar as configurações variadas e suas possíveis implantações. Realizou ainda questionários com o público, que codificou em diagramas para determinar a compatibilidade entre atividades concomitantes. $\mathrm{O}$ processo de desenvolvimento foi inventado ao longo de seu desenvolvimento, pois, segundo o arquiteto, a criação de algo novo não poderia partir de um método preestabelecido, reiterando o que sempre defendeu como papel da arquitetura: criar questões e não se dispor a simplesmente resolver problemas.

Tendo como princípio que o que importa são as pessoas e não os edifícios, e que é o uso que confere importância à arquitetura, Price se preocupava com a vida útil dos edifícios que projetava, considerando que deveriam estar abertos à adequação, absorvendo novas condições e padrões de vida, e que pudessem ser demolidos, uma vez que não deveriam durar mais tempo do que necessário.

Embora não tenha sido construído, o Fun Palace foi considerado uma referência conceitual para o desenho de outros edifícios como o Centre Pompidou (1977), de Renzo Piano e Richard Rogers, e o Millenium Dome (1999), de Rogers e Mike Davis. 


\section{C2.5 Liceu David d'Angers (1978-80) Angers, França Yona Friedman}

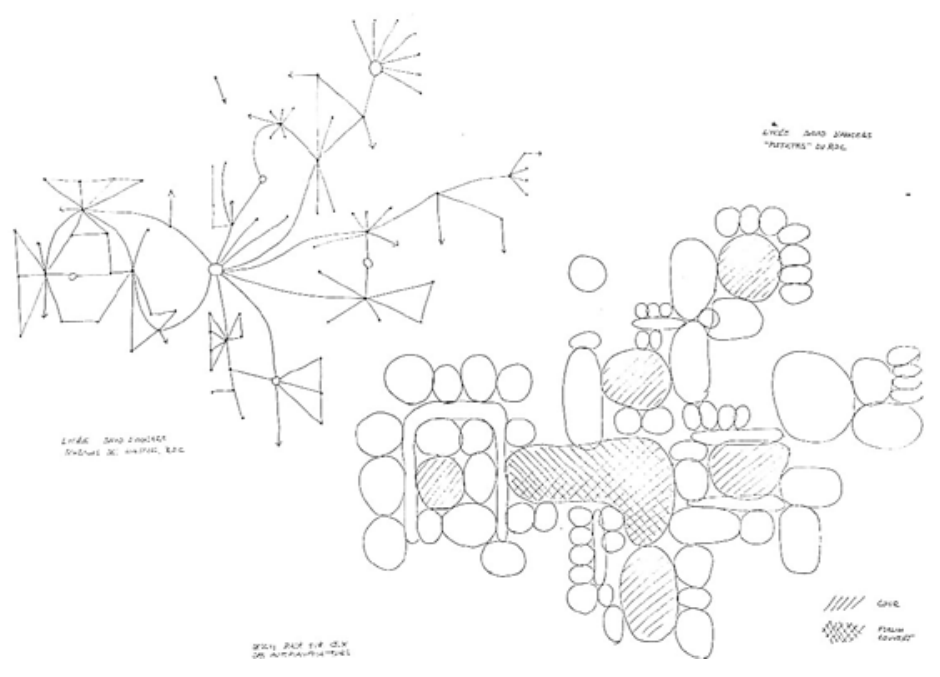

O projeto para o Liceu David D'Anger permitiu que Yona Friedman desencadeasse um processo de desenvolvimento coletivo para o projeto de uma escola, e aplicasse sua tese de flexibilidade do espaço. Por meio de um conjunto de regras, aplicadas em diferentes etapas, os futuros usuários do edifício puderam tomar decisões baseadas no emprego de um sistema modular industrializado, recombinando elementos que resultaram no que ele denominava de 'estética da aleatoriedade'.

Com exceção da dimensão dos ambientes, regulados pelo Ministério da Educação, todos os elementos arquitetônicos foram projetados e decididos pelo grupo que ocuparia o edifício. $\mathrm{O}$ interior das salas e sua distribuição também foram determinados pelos professores e alunos, enquanto o arquiteto mediava as decisões e organizava as informações que resultaram no perímetro e nas elevações.

Assim, o arquiteto agiu como mediador para a realização dos desejos dos usuários, garantindo a flexibilidade do espaço como conceito chave para a transferência das decisões. Essa flexibilidade garantia, inclusive, modificações após o uso, uma vez que Friedman pretendia que o processo fosse repetido sempre que desejado.
Para que o projeto pudesse incluir demandas coletivas, houve uma necessária reordenação dos meios de expressão, como forma de se estabelecer uma linguagem esquemática comum para a cooperação entre os participantes. Esse sentido coletivo de comunicação estimulou o uso de diagramas, um meio mais intuitivo e pouco utilizado então. Esses diagramas são, para Friedman, a mensagem codificada que ele recebe dos outros.

Assim, a representação arquitetônica convencional - que emprega projeções ortogonais das quais derivam plantas, elevações e cortes - foi substituída por diagramas que determinavam as relações entre os espaços, seus arranjos e conexões, posteriormente interpretados como expressão arquitetônica dos desejos e escolhas coletivas.

A definição e distribuição dos usos do edifício pelas pessoas que o utilizariam derrubaram certezas consolidadas, tais como: a necessidade de uma circulação direta e eficiente que deveria encurtar o tempo de deslocamento entre salas, substituída por passeios longos, contemplativos e necessários para romper com um sentido de produtividade do dia o dia. 


\section{C2.6 Vila Espacial (1958-1964) Yona Friedman}

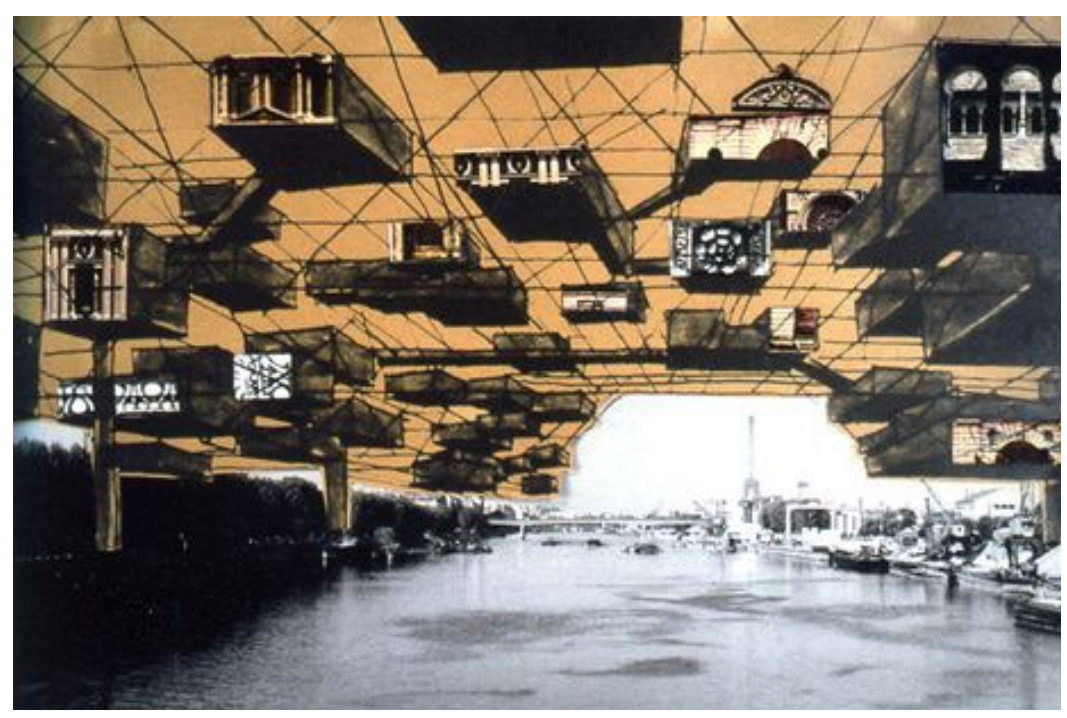

Com o projeto da Vila Espacial, Yona Friedman elaborou e expressou muitos de seus princípios:

, Não demolir as cidades existentes consolidadas, mas construir sobre elas, adensando-as como meio de evitar seu espraiamento - uma estrutura aérea com impacto mínimo sobre o solo poderia expandir a cidade dentro de seus limites; , Construir o mínimo, de maneira a fornecer soluções técnicas adaptáveis, passiveis de serem manipuladas pelos futuros habitantes, de acordo com suas necessidades e possibilidades;

, Proporcionar a infraestrutura necessária, a fim de garantir ao futuro habitante condições de manipular, construir e transformar seu ambiente, com estruturas leves e temporárias, e assim delegar as decisões e proporcionar liberdade sobre os modos de habitar;

, Adaptar o projeto ao usuário, e não o usuário ao espaço projetado, de maneira que a cidade não ofereça resistência aos seus habitantes, mas os obedeça com um desenho urbano adaptável.

Os desenhos da Vila Espacial não apresentam plantas ou fachadas, pois podem, segundo Friedman, se tornar qualquer coisa. Oferecendo um contraponto à idealização do espaço funcional e acabado, enfatiza a participação, a abertura aos desvios inventivos dos indivíduos, o que levou o arquiteto a pensar modelos de comunicação para mediar decisões em grupo. Assim, suas imagens e desenhos comunicativos contribuem para a elaboração de uma retórica sobre como a arquitetura poderia ser informada pelo comportamento social.

Esses desenhos provocam o imaginário para uma nova configuração espacial da sociedade que surgiria a partir da emancipação proporcionada pela automação da produção, liberando o indivíduo para o lazer. Essa visão utópica era então informada pelo debate revisionista do modernismo e reverberava também em outros experimentos, como no metabolismo japonês, nas especulações de grupos como Archigram e Superstudio, e na Nova Babilônia (1956-1974) de Constant.

Ecos contemporâneos dessas especulações são atualizados pela inversão distópica que a prontidão impõe. Os trabalhos de Friedman ressurgem, assim, como potencial comunicativo sobre a identidade coletiva diante da baixa qualidade das condições de vida no espaço urbano, ascendendo debates sobre o papel do Estado na produção das cidades, processos participativos e de autogestão, e o impacto e as possibilidades transgressivas da arquitetura neste contexto. 


\section{C2.7 Quinta Monroy (2003-2004) Iquique, Chile ELEMENTAL}
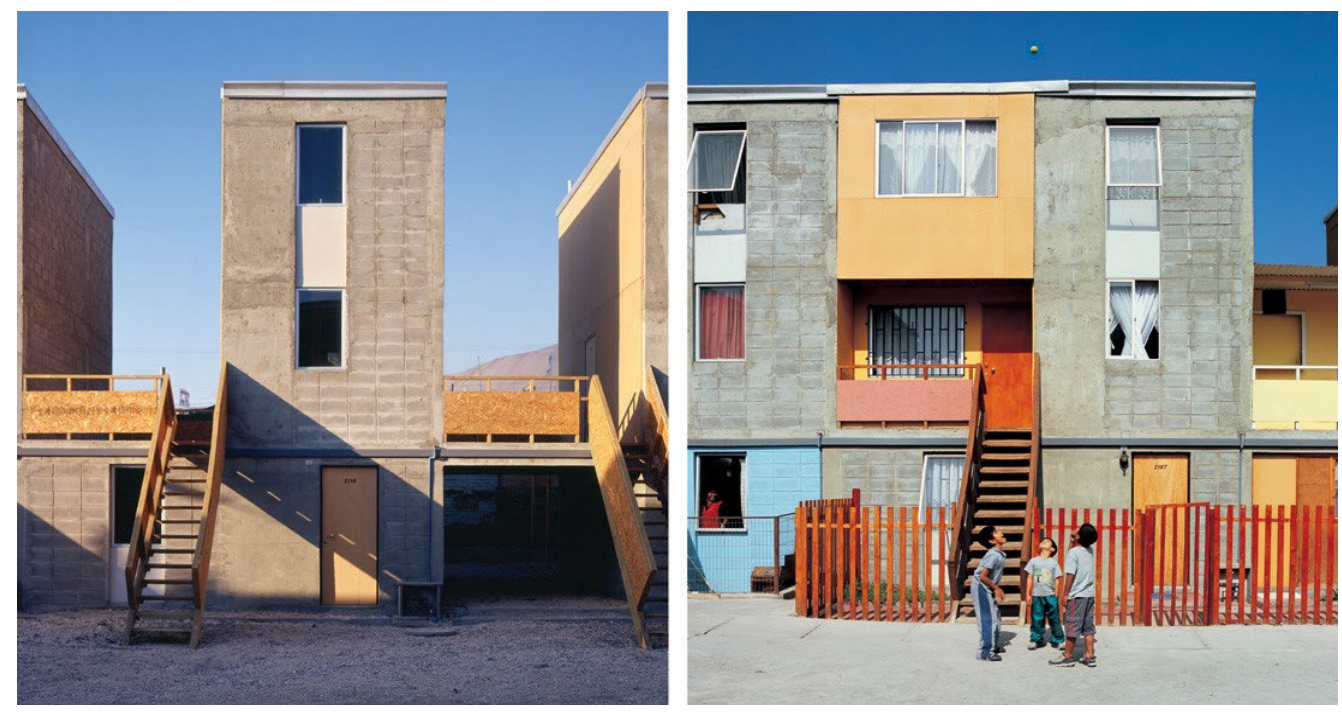

Diante do consenso de que a urbanização é um processo inevitável, e sua rapidez demanda soluções que consigam equilibrar uma delicada equação de fatores envolvendo escala, velocidade e recursos, Aravena demonstra a seguinte projeção: até 2030, dois bilhões de pessoas estarão vivendo em cidades abaixo da linha da pobreza. Isso significa construir uma cidade de um milhão de habitantes por semana.

Elemental é uma plataforma criada pelos arquitetos Alejandro Aravena, Andrés lacobelli e Pablo Allard, em 2001, no Chile, para tentar responder a esse problema e desenvolver projetos habitacionais de baixo custo. O momento era então favorável e novas políticas públicas estavam sendo gestadas, dentre elas o programa Vivienda Social Dinámica sin Deuda (2013), no qual cada família receberia um voucher de U\$ $7.500,00$ para subsidiar sua demanda habitacional, devendo cobrir a aquisição de propriedades, o desenvolvimento do projeto e a construção de uma casa.

O projeto para a Quinta Monroy procurou responder pragmaticamente à demanda de transferência de 100 famílias que ocupavam um terreno central e em vias do despejo, na cidade de lquique, considerando que o recurso escasso deveria garantir a compra de um terreno que possibilitasse a permanência daquele grupo próximo

de sua rede de contatos e emprego.

O conjunto de restrições e decisões demandava o envolvimento e a participação das famílias no processo do desenho. O desenvolvimento do projeto impunha desafios contingenciais, uma vez que a verticalização engessaria as unidades em $40 \mathrm{~m}^{2}$, e a desejável construção de $80 \mathrm{~m}^{2}$ não cabia no orçamento.

Este impasse levou à reformulação do problema, ou ao que Aravena define como organização da informação cujo propósito é extrair da complexidade um raciocínio sintético e propositivo. Dessa reformulação lógica resultou a decisão de garantir, com o recurso público, aquilo que as famílias não conseguiriam fazer individualmente, possibilitando futuras expansões. Trata-se de uma compreensão da casa como um processo inserido em um sistema aberto capaz de canalizar todas as forças disponíveis, e a capacidade individual das famílias na autoconstrução, o que envolveu inclusive a organização dos grupos para futuras decisões sobre a gestão do espaço coletivo.

Elemental emprega com precisão ferramentas de validação política e social, ampliando um raciocínio sobre arquitetura como processo, resultando num objeto poroso e em constante transformação, no qual as tensões entre o projeto e o espontâneo se chocam sem se anular. 


\section{C2.8 Pavilhão Alemão HIII (2016) Protótipo para um centro comunitário pós terremoto (2017) Al Borde em colaboração com El Sindicato Arquitectura Equador}
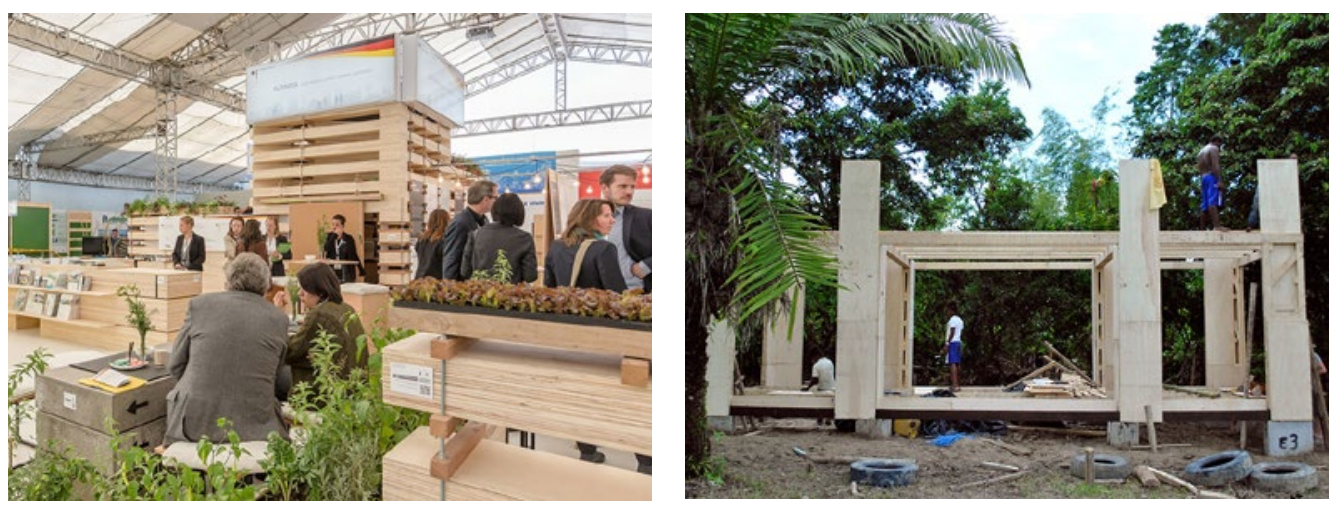

O terremoto de 2016, no Equador, foi um primeiro impulso para que arquitetos passassem a se envolver com a construção de moradias emergenciais em áreas rurais. No entanto, o efeito dessa mobilização perdurou, como uma espécie de reviravolta que descortinou um promissor modo de atuar em áreas desassistidas pelo governo e sem qualquer investimento privado, dado o desinteresse da indústria da construção civil pelos altos custos gerados decorrentes da distância em relação aos grandes centros.

Poder acessar comunidades distantes da atuação de arquitetos para, junto com elas, identificar habilidades e técnicas construtivas - assim como engenhosidade e força de trabalho - a serem empregadas no desenvolvimento de projetos com impacto real na melhoraria das condições de vida locais. Essa, passou a ser alternativa de trabalho para uma geração de jovens arquitetos, sem perspectivas de bons contratos nas grandes cidades equatorianas.

Parte dessa história é contada no documentário Hacer mucho com poco (2018), produzido pelo Al Borde, um grupo de arquitetos baseados em Quito que conquistou maior reconhecimento internacional e passou a atuar como uma espécie de embaixador de um fenômeno local mais amplo.

Enquanto desenvolvia o projeto para construir uma casa permanente para as famílias afetadas, com um subsídio de 10mil dólares destinados à construção de casas temporárias, o Al Borde foi convidado a projetar um pavilhão para a Alemanha, num evento da ONU, o Habitat III, realizado em Quito. Segundo o grupo:
“Fazer um pavilhão para uma exposição é um problema básico e concreto de desenho, assim como fazer uma casa que responda a uma catástrofe natural. Colocá-los juntos, no entanto, cria uma nova relação entre o consumidor e o ciclo de produção" (AL BORDE, 2016, online, tradução minha).

O pavilhão foi tratado como um depósito de materiais, e a verba gasta neste tipo de evento temporário, que ao final gera muito lixo, foi revertida em matéria prima para a construção do protótipo de quatro modelos de casas projetadas para o socorro pós-terremoto. O grupo participou de todas as etapas do trabalho, dos orçamentos ao projeto, do gerenciamento da obra à construção, que envolveu também estudantes e a mão de obra local.

Com isso, o Al Borde, em parceria com El Sindicato Arquitectura, conseguiu atingir o custo de $U \$ 106,00 \mathrm{~m}^{2}$. Graças à sua articulação para transferência de recursos e a participação direta na construção das casas, disseminaram o conhecimento de novas técnicas, elaboradas a partir da identificação das habilidades de carpintaria dos habitantes, e a possibilidade de diversificar e replicar o repertório local de construção a partir do sistema desenvolvido com a utilização de chapas de compensado. 


\section{C2.9 Sem título - imagem de cidade vendida pelo mercado imobiliário $X$ imagem de cidade real, ou Nova Luz, mas poderia ser Porto Maravilha (2012-2013) \\ MAR - Rio de Janeiro Coletivo Usina}

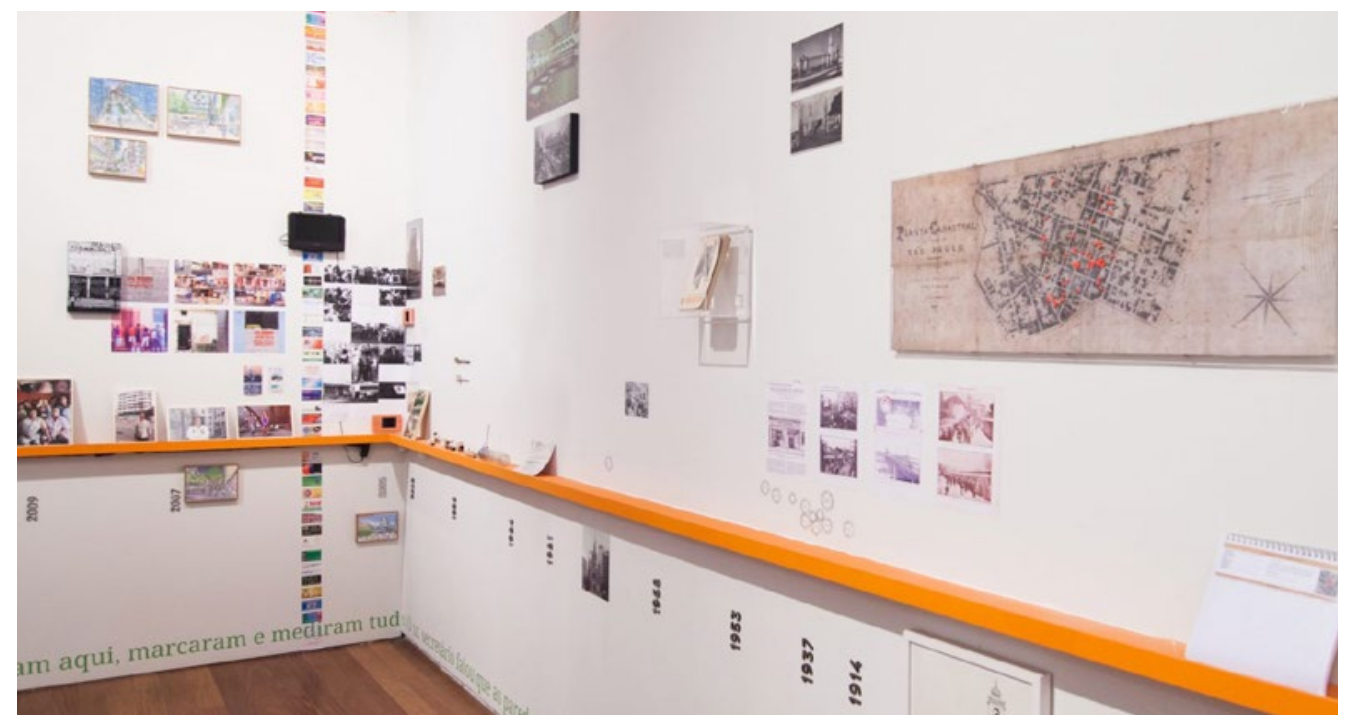

A exposição $O$ abrigo e o terreno: arte e sociedade no Brasil (2013), com curadoria de Paulo Herkenhoff e Clarissa Diniz, inaugurou o MAR e um projeto previsto para durar quatro anos, mas posteriormente modificado. Voltado a pensar as relações sociais no país por meio da arte como um âmbito de elaboração subjetiva e de potência política, sua primeira proposição, oportunamente, procura explicitar a ambiguidade da criação do museu e sua espécie de pecado original, uma vez que exerce a função de alavanca cultural e de emblema de uma operação urbana violenta sustentada por questionáveis parcerias público-privadas.

A proposição da Usina crava na exposição um espaço de expansão desse debate, buscando elaborar essa condição como um traço constituinte de tantas outras transformações urbanas que se deram historicamente no país, e que estavam em curso com grande intensidade na cidade do Rio naquele momento.

O contexto estava dado: o Porto Maravilha, mas poderia ser a Nova Luz, território conhecido da equipe paulistana. Pensando o trabalho de arte como curadoria, e com clara referência ao trabalho do grupo nova-iorquino Group Material, a estratégia de infiltrar o discurso curatorial sobre o Porto Maravilha não devolve uma imagem, ou um todo de fácil consumo. O espaço foi ocupado por uma linha do tempo que cotejava a região paulistana com a carioca, envolvendo extensa pesquisa sobre os consecutivos apagamentos da região da Luz, desde o início do século XX, quando o bairro, habitado pelo povo negro, ainda era chamado Santa Iphigênia, em homenagem a sua santa.

O trabalho demandava tempo e atenção do público, uma vez que o conteúdo denso surgia em diversas mídias. Estavam presentes: vídeos institucionais, que propagandeavam as intervenções, editados com outros que retratavam as remoções; reproduções de pinturas e mapas históricos; levantamentos e depoimentos; fotografias e desenhos; uma biblioteca sobre o tema, e cachimbos para o consumo de crack, razão pela qual a região da Luz tornou-se conhecida nas décadas recentes. Além disso, frases de moradores removidos do Morro da Providência, no Rio, e da região da Nova Luz, em São Paulo, cruzavam as paredes. Como parte da exposição, a Usina também realizou um programa público de debates que estabeleceu correspondências com os projetos do Poço da Draga, na Praia de Iracema, em Fortaleza, que incluiu a construção do Acquário do Ceará, e o Novo Recife, que envolveu a região do Cais José Estelita. 


\section{C2.10 Victims (1983) John Hejduk}

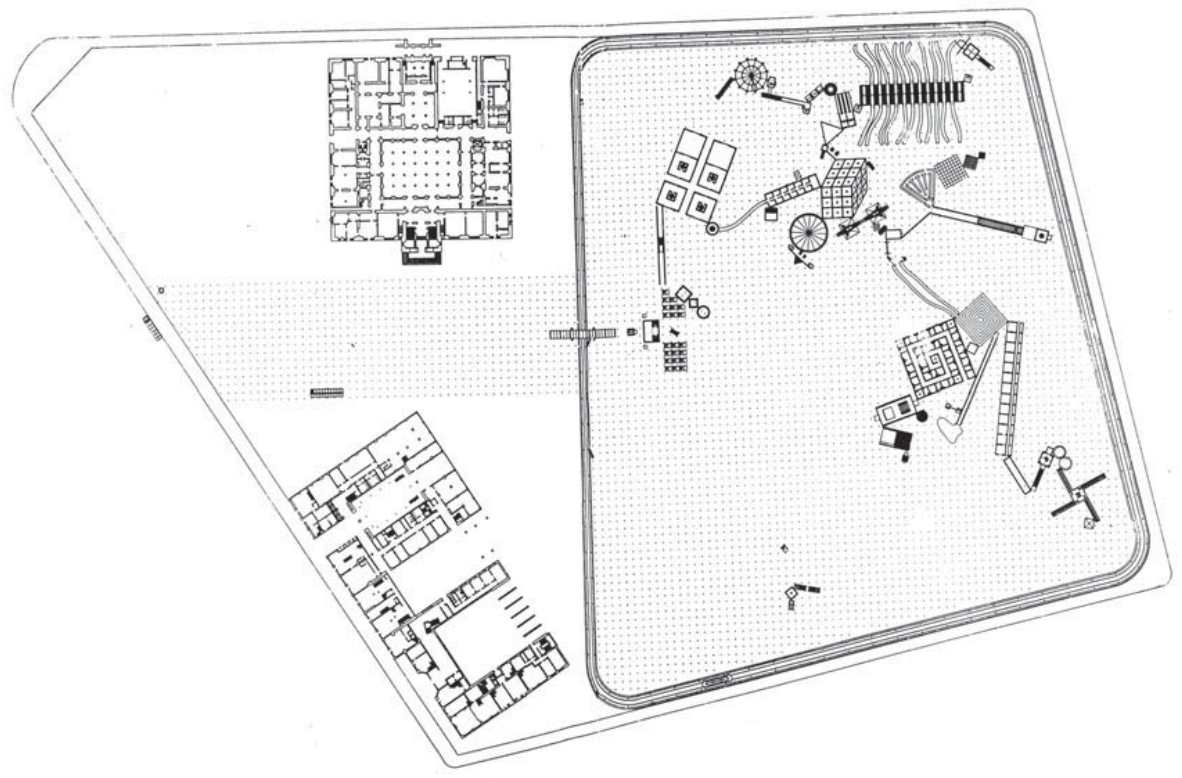

Este catálogo de 67 estruturas é apresentado à cidade e aos cidadãos de Berlim. Uma possibilidade é que todas as 67 estruturas possam ser construídas ao longo de dois períodos de 30 anos, a outra possibilidade é que nenhuma das estruturas seja construída. Uma terceira possibilidade é que algumas estruturas sejam construídas. A decisão é da cidade e dos cidadãos de Berlim.

John Hejduk

Em 1983, Hejduk projetou as 67 estruturas que compõem Victims para um concurso promovido pelo Internationale Bauausstellung, na cidade de Berlim, e que tinha como objetivo pensar propostas de ocupação para o quarteirão onde se situaram as sedes da SS e da Gestapo, dois edifícios remanescentes e a área no entorno, transformando-o em um espaço público para memória e reflexão sobre o nazismo.

O projeto previa envolver o quarteirão com uma dupla camada de cercas, em meio às quais um trem se deslocaria constantemente. Entre os dois edifícios, um caminho conduziria à entrada principal a partir de onde seria possível tomar o trem ou acessar o terreno por meio de uma ponte. No projeto, Hejduk fornece apenas algumas instruções iniciais, como instalar os trilhos, plantar as mudas de árvores, construir a ponte levadiça, a portaria e a torre do relógio.

Assim, a proposta, que ganha uma menção especial do júri, representa um entre inúmeros cenários possíveis de disposição do projeto no terreno, uma vez que se comporta como um organismo ou um sistema aberto, no qual cada estrutura é também um personagem constituído por uma forma e por um poema escrito pelo arquiteto, ambos elementos que informam e encarnam esse objeto-sujeito.

Desta abertura deriva um jogo de possibilidades narrativas a ser desenvolvido no tempo - em dois intervalos de 30 anos -, e no espaço, na medida em que tais estruturas fossem construídas e deslocadas, estabelecendo relações entre si, com a vegetação de folhagem perene, a ser implantada sobre os cruzamentos de uma quadrícula uniforme, e com os moradores de Berlim, que decidiriam como e quando construir novas estruturas.

Victims sugere pensamentos, impressões e interpretações simbólicas sobre a memória coletiva sem aderir diretamente ao passado do lugar, que é apenas sugerido como é o caso das estruturas $n^{\circ} 45$ Detentor dos registros, $n^{\circ} 59$ Quarto daqueles que olharam para outro lado, $n^{\circ} 65$ Exilados e $n^{\circ} 66$ Desaparecidos, em que essa relação fica mais evidente. Desse modo, Hejduk articula um pensamento reflexivo sobre a noção de projeto, recorrendo a fragmentos em constante deslocamento, como presenças surreais entre a arquitetura e a escultura, assim como entre a teoria e prática. 


\section{C2.11 A Nonsite (1968) Franklin, New Jersey Robert Smithson}

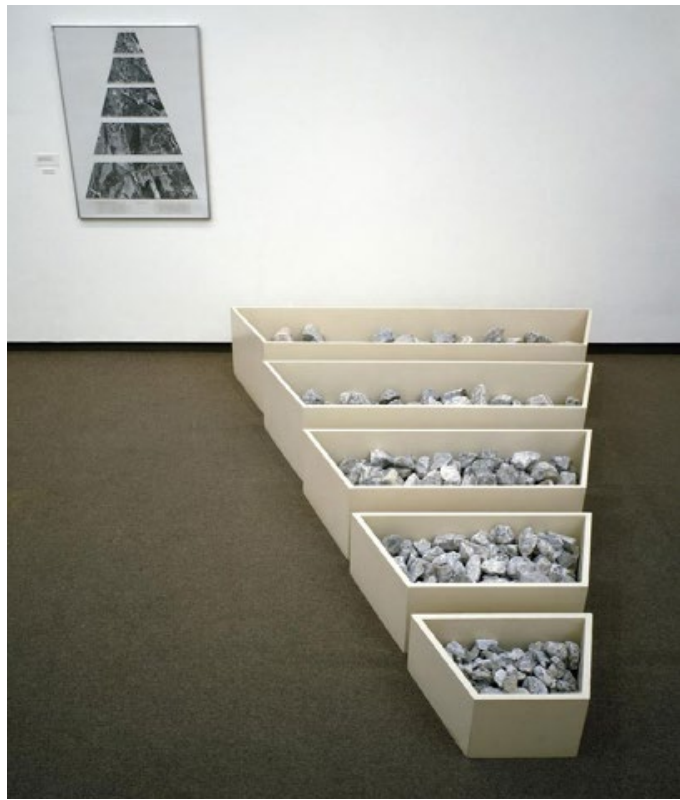

Entre o local real em Pine Barrens e o próprio não-sítio existe um espaço de significado metafórico. Pode ser que "viajar" neste espaço seja uma vasta metáfora. Tudo entre os dois locais pode se tornar material metafórico físico desprovido de significados naturais e suposições realistas. Digamos que alguém faça uma viagem fictícia se decidir ir ao site do Não-Site. A "viagem" torna-se inventada, planejada, artificial; portanto, pode-se chamá-lo de não viagem a um local de um não local. Uma vez que alguém chega ao "campo de aviação", descobrese que ele é feito pelo homem na forma de um hexágono, e que mapeei este local em termos de limites estéticos em vez de limites políticos ou econômicos"

Robert Smithson

Cada um dos não-sítios realizados por Robert Smithson, em 1968, é conformado por três partes, ou elementos reunidos e dispostos no espaço expositivo. Uma primeira parte consiste na documentação do sítio utilizando os tradicionais meios de representação bidimensional como fotografias e mapas junto de textos estritamente descritivos. A segunda parte são as amostras minerais coletadas no site, como areia, pedras e detritos, que são arranjadas num terceiro elemento, caixas fracionadas com formas geométricas que sugerem e acentuam a perspectiva.

Tal disposição propõe um deslocamento que opera diretamente sobre as instâncias de representação para provocar rebatimentos no site e, assim, produzir um embaralhamento com inversão de sinais entre real e o "espaço de significado metafórico".

Com este procedimento, Smithson formula uma sofisticada interrogação que confere um papel central à linguagem que, quando transposta para a prática arquitetônica, contribui para uma reflexão sobre como mobilizar os meios de representação tradicionais de modo a ampliar seu repertório, compondo também o textual como camada verbal e matérica, não subserviente ao visual. Tal distensão recai também sobre os endereçamentos possiveis da linguagem arquitetônica ao real, que ao não se limitar apenas à descrição fenomenológica do sítio específico, possibilita novas especulações críticas e teóricas com implicações políticas, econômicas e sociais multiplicando as possibilidades de operações empregada pela prática arquitetônica. 


\section{C2.12 Six Durations of a Split Second: The Killing of Harith Augustus (2019) Chicago Architecture Biennial Forensic Architecture}

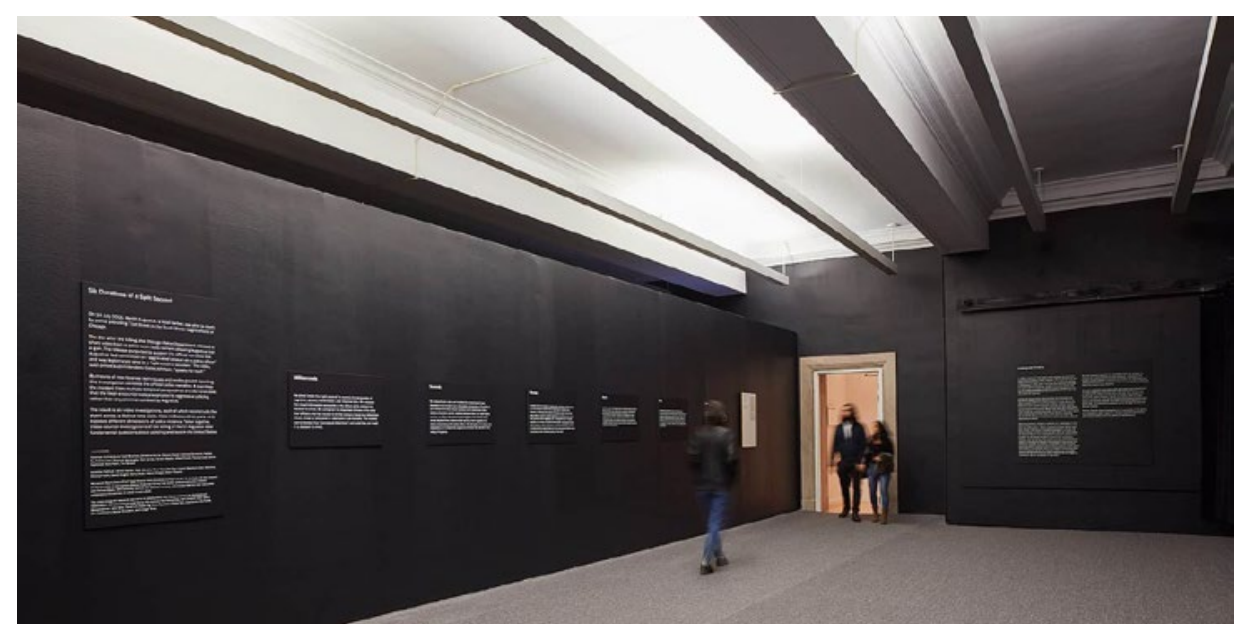

A decisão de utilizar força letal é tomada numa fração de segundo e baseia-se na segurança do oficial e da comunidade circundante. Esse depoimento, do superintendente do departamento de política de Chicago, abre o vídeo do Forensic Architeture que propõe investigar o uso de força letal como resposta reativa - justificativa recorrente para o emprego de disparos fatais realizados por policiais em serviço.

O grupo se deteve num segundo extraído de dois vídeos que registram a ação policial que culminou na morte de Harith Augustus, um homem negro de 37 anos, alvejado por cinco tiros durante uma batida policial, na parte sul da cidade. Contestando a narrativa oficial, de que Augustus teria reagido à abordagem e tentado utilizar a arma que carregava consigo, o trabalho procura apoiar a família de Augustus e o movimento negro da região sul da cidade, cujas manifestações após a sua morte foram agressivamente reprimidas.

Os quadros do vídeo foram transformados em milissegundos e informaram a construção de uma animação 3D que possibilitou ao Forensic Architecture, auxiliados por um neurocientista, isolarem os comportamentos de todos os cinco policiais envolvidos no incidente, analisando suas ações e reações e interpretando a sensação de risco desde a perspectiva do policial atirador - o que ele viu, e a quais estímulos foi exposto. A comparação das imagens, quadro a quadro, demonstra que, mesmo tendo Augustus cooperado e apresentado seus documentos, inclusive sua licença para portar a arma de fogo que estava travada em seu coldre quando foi morto, a equivocada abordagem policial leva a uma escalada de tensão e a um comportamento reativo por parte da vítima. No entanto, apenas um dos policiais saca sua arma e reage violentamente, numa conduta nitidamente enviesada por preconceito racial.

Ao longo de um ano de investigação, o Forensic Architecture e os curadores da exposição estiveram envolvidos com organizações, ativistas e lideranças comunitárias, chegando a uma decisão conjunta de não apresentar qualquer imagem sobre o caso no espaço expositivo, por entenderem que havia uma contradição implícita entre a necessidade de olhar e a dificuldade de mostrar as imagens de violência. No entanto, estas ficaram disponíveis no site do grupo e no da bienal como forma de ampliar o acesso a ferramentas e técnicas para construção de contranarrativas. No espaço expositivo foram exibidos apenas textos relativos à sequência de eventos e suas temporalidades, desde os anos de segregação racial na cidade de Chicago, passando pelos minutos que antecederam a abordagem equivocada que resultou na morte de Augustus, até as horas e dias após o incidente no qual o departamento de polícia reprimiu protestos e divulgou vídeos editados que descontextualizavam o que de fato ocorreu no local do incidente de modo a manipular a opinião pública. 

3.

São Paulo:

dois projetos,

quatro exposições 


\section{A Marquise do Ibirapuera}

É necessário, aqui, retomar a diferença entre as abordagens não convencionais do projeto arquitetônico de forma a diferenciar processos participativos e inclusivos nas etapas de projeto e construção dos projetos intencionalmente abertos a transformações pelo uso. Um primeiro procura incluir o usuário não especializado nas definições do projeto e de sua construção, enquanto o segundo parte da indeterminação como premissa do programa, aspirando uma abertura para públicos e usos múltiplos que se darão espontaneamente. Há ainda os casos em que são inesperadas as apropriações ocasionadas por desvios das intenções originalmente programadas.

Tomando como exemplo uma cidade como São Paulo, dois casos celebrados de espaços "desprogramados" e abertos às transformações imprevistas chamam atenção. Resultam de partidos distintos, e ambos repercutem no debate sobre os trânsitos entre arte e arquitetura e sua capacidade de estabelecer intercâmbios entre museu, obras de arte e o espaço público como dimensões do cotidiano em sua diversidade.

O primeiro exemplo é a Marquise do Ibirapuera. O projeto de Oscar Niemeyer e equipe contou com a participação do arquiteto desde as etapas iniciais de sua concepção, quando da criação do parque, inaugurado durante as comemorações do IV Centenário da cidade, em 1954. Niemeyer esteve envolvido inclusive na formulação do programa de necessidades, contribuindo com a determinação das funções de cada pavilhão. Destinada a ser elemento de ligação e apoio para os pavilhões expositivos e instituições que ocupam suas extremidades, a Marquise do Ibirapuera subverte sua destinação original de importância secundária, e ganha protagonismo como espaço de acolhimento das manifestações culturais espontâneas e plurais que a povoam, tornando-se um dos mais significativos espaços públicos da cidade.

Ainda que o extenso passeio coberto, pensado como conexão entre os pavilhões expositivos, represente um programa vago - particularmente quando inserido na escala 
do parque, um dos mais importantes equipamentos gratuitos da cidade -, é indiscutível que a planta livre, conformada por um chão e uma cobertura de $28.000 \mathrm{~m}^{2}$, que extravasam para o parque por todos os lados, desperta uma atração e um impulso que agem sobre corpo, convidando-o a ocupar e a experimentar livremente o espaço.

O desafio em investigar como se dá essa ocupação foi o enfrentamento proposto pelo arquiteto Eduardo Gurian em sua dissertação Marquise do Ibirapuera: suporte ao uso indeterminado (2014), na qual procurou registrar graficamente a dinâmica dos usos espontâneos da Marquise hoje <imagem C3.1 p.204>. Como referência para este trabalho, o autor valeu-se das Heliografias (1980-1986) de Léon Ferrari, nas quais o artista argentino, radicado em São Paulo, criava complexas relações espaciais a partir da utilização de catálogos de letraset aplicados às plantas baixas.

Embora não estejam claras, as regras são perceptíveis, e são analisadas geometricamente em concordância com o meio escolhido por Gurian: o desenho técnico arquitetônico. A análise dos desenhos assume a linguagem da geometria e traduz o movimento dos corpos em vetores, que se recombinam constantemente, ou como campos que expandem seus limites físicos para exercerem movimentos de atração e repulsão à medida que se “deslocam com violência” (GURIAN, 2014, p.219). A dinâmica se altera ao longo do dia, entre manhãs mais calmas e acolhedoras, tardes ruidosas e noites velozes, que assustam os desavisados pelo caminho, evidenciando o desafio da mediação constante entre consensos e dissensos reiteradamente negociados sob a Marquise.

As responsabilidades individuais são reguladas e mediadas conforme novos usos são inventados, renovando potenciais conflitos. Conflitos que não podem ser compreendidos sob uma perspectiva harmônica, assim como não se encerram no corpo a corpo cotidiano. Outras camadas de negociação atravessam a Marquise, como aquelas que concorreram para o fechamento do rinque de patinação, nos anos 1950, motivadas por acusações de atentado ao pudor endereçada aos patinadores sem camisa, ou pelos recentes "rolezinhos" que desconcertaram a segurança do parque. Enquanto ambulantes irregulares fogem da fiscalização e ciclistas atropelam caminhantes, já disputaram aquele espaço um estacionamento irregular de veículos e até 
exposições de aparato militar, como demonstra a linha do tempo que integra a pesquisa de Eduardo Gurian ${ }^{158}$.

É essa lógica de disputas e conflitos sob a Marquise que atravessa a história do Museu de Arte Moderna de São Paulo (MAM-SP). O “museu nômade”159, até 1968, alojou-se numa infraestrutura prevista para ser temporária ${ }^{160}$, mas que permaneceu, como demonstra a curadora Ana Maria Maia no artigo "Museu de Cera, Pavilhão da Marquise, Pavilhão Bahia, Museu de Arte Moderna de São Paulo” (2013). Segundo Maia (2013, p. 37), “o que hoje persiste sob a marquise é o resultado de um acúmulo de histórias institucionais e pessoais”, ou seja, uma história mundana. E é esse contexto que impulsiona duas curadorias recentes a atualizarem o debate sobre a presença desta instituição e sua indissociável condição histórico-espacial atravessada pela sua ligação com a Marquise e o Parque.

As exposições P33 - Formas únicas da continuidade no espaço (2013), $33^{\circ}$ edição do Panorama da Arte Brasileira,

A linha do tempo de Marquise do Ibirapuera: suporte ao uso indeterminado (2014), apresenta a pesquisa histórica de levantamento de ocorrências diversas sob a marquise noticiadas em jornais e revistas. Abarca desde os eventos do festejo do IV Centenário (1954), passando por espetáculos populares, desfile de cachorros, exposição de primavera, programações de carnaval, estacionamento irregular, congressos religiosos, exposição do exército durante a ditadura militar (19641985), solenidades oficiais, prestação de serviços públicos, formaturas, feiras e shows diversos, até os fenômenos mais recentes, como os "rolezinhos", e a apropriação por parte grupos de vindos de diversas partes da cidade (GURIAN, 2014, p.126-209), demonstrando sua vocação de refletir e visibilizar comportamentos e manifestações culturais.

Termo utilizado por Felipe Chaimovich, curador do MAMSP desde 2002, no texto O museu nômade no Brasil (2008), no qual relata a trajetória do museu, desde sua primeira sede na Rua 7 de Abril - passando pela OCA, pelo Palácio das Industrias, entre outros endereços -, até se instalar no parque do Ibirapuera. Chaimovich associa os deslocamentos dos primeiros quinze anos a uma condição adquirida de independência entre a instituição e a posse de um edifício.

O MAM-SP, fundado em 1948 por Francisco Matarazzo, ocupa hoje um local cuja a implantação data da inauguração do Parque do Ibiriapuera, conforme registro da planta geral do parque, de 3 fevereiro de 1954 (In: MAIA, 2013, p.38). Originalmente destinado ao Museu de Cera (1954-1955), este espaço foi também ocupado por um rinque de patinação (1955). Passou a ser alugado para diversos fins e entre 1956 e 1958, foi chamado de Pavilhão da Marquise, depois como Pavilhão Folclórico. Em 1959, recebe a exposição Bahia no Ibirapuera, e passa a ser chamado de Pavilhão Bahia. Após mais um período de locação para fins diversos, é concedido ao MAM-SP, em 1968, pelo então prefeito Faria Lima. (MAIA, 2013, p.29-37). 
com curadoria de Lisette Lagnado, e A marquise, o MAM, e nós no meio (2018), com curadoria de Ana Maria Maia, em colaboração com o educativo do museu e O Grupo Inteiro, reverberam a intensidade e a diversidade das experiências que as relações de vizinhança com o Parque e a Marquise impõem ao MAM.

\section{P33 - Formas únicas da continuidade no espaço (2013)}

Pode-se afirmar que a $P 33$ propôs uma interpretação "retroprospectiva"161 do MAM-SP ao retomar a origem dos panoramas de arte brasileira, criados em 1969, e cujo objetivo era (re)constituir ${ }^{162}$ o acervo do museu, ao mesmo tempo que este se transferia para o pavilhão temporário existente sob a Marquise. Esse momento marcante passa por uma revisão histórica informada pelas múltiplas interpretações que a narrativa crítica, proposta por Lisette Lagnado e pela curadora adjunta Ana Maria Maia, estabelece ao relacionar esses dois acontecimentos como constituintes do MAM-SP, e, portanto, disparadores de uma autoanálise da instituição, tendo em vista suas perspectivas futuras.

Daí a intenção de conduzir uma investigação sobre os arquivos do MAM-SP, repartido entre as instituições que

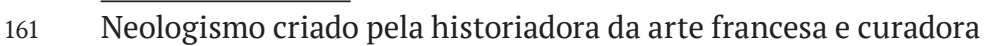
Catherine David para explicar sua pesquisa para a Documenta $X$ (1997), elaborada como um olhar para o passado que ao revisitar as edições anteriores possibilitasse uma compreensão mais clara da situação cultural do presente e suas perspectivas futuras.

162 Em 1963, Francisco Matarazzo Sobrinho - Ciccillo - polêmico empresário, fundador do MAM e empreendedor por trás da fundação do Parque do Ibirapuera, encontrava-se mais envolvido com a consolidação da Bienal de São Paulo doando a coleção de arte moderna. O MAM SP, que já se encontrava fragilizado pela prioridade financeira e de empenho das equipes dedicadas às bienais, se reorganiza graças à persistência do seu grupo de conselheiros. Os panoramas de arte contemporânea do MAM SP aconteceram anualmente entre 1969 e 1991, quando passam a ser bienais, e são responsáveis por recompor o acervo do museu por meio de aquisições e doações, conformando contraditoriamente uma coleção mais voltada à arte contemporânea brasileira. 
dele nasceram - o MAC-USP, que herdou sua coleção de arte moderna, doada por Ciccillio Matarazzo, em 1963, e a Bienal de São Paulo, iniciada como programa de exposições do MAM-SP. A pesquisa para a exposição envolveu e provocou a instituição na medida que propunha uma revisão da maneira como elabora e conta sua própria história, buscando uma afirmação de sua identidade. Por essa razão, a arquitetura atravessa a exposição em distintas camadas, revisitando sua condição nômade, a origem de sua atual sede, e abrindo-se para especulações sobre possíveis futuros.

Uma primeira camada contribui para que se elabore a construção de um ideal de museu moderno no Brasil, representada pela seleção de projetos exemplares para o pensamento da museografia brasileira, como o Museu de Arte Moderna do Rio (1954), de Affonso Eduardo Reidy, o projeto da exposição Bahia no Ibirapuera (1959), de Martim Gonçalves e Lina Bo Bardi ${ }^{163}$, que ocupou o mesmo pavilhão onde, em 1983, Bo Bardi projetou a adequação das instalações do MAM-SP, consolidando sua permanência sob a Marquise ${ }^{164}$ e inaugurando o controverso debate com Oscar Niemeyer, que defendia o partido original que previa a Marquise como espaço vazio ${ }^{165}$.

Também no âmbito histórico foram apresentadas fotografias de Michel Aertsens, que documentam a construção do MAM-RJ, e de Marcel Gautherot <imagem C3.2 p.205> que retratou o Cassino da Pampulha (1943)

Em 1959, o pavilhão temporário foi escolhido por Lina Bo Bardi e o dramaturgo Martim Gonçalves para receber a exposição Bahia no Ibirapuera que integrava V Bienal de Arte de São Paulo. Dessa forma estaria próxima o suficiente para integrar a exposição principal, mas seria capaz de estabelecer uma desejada autonomia expográfica, razão pela qual tornou-se um paradigma, desafiando os princípios do cubo branco para "afirmar o teor sincrético e eclético que dedicou aos objetos comuns, ou à chamada arte popular" (MAIA, 2013, p.31).

$\mathrm{O}$ antigo Museu de Cera, atual MAM-SP, assim como outras construções sob a marquise, foram tombados pelos Condephaat conforme a ata de tombamento do Parque do Ibirapuera, publicada no Diário Oficial do Estado, no dia e 25 de janeiro de 1992, p.22.

165 A polêmica se faz presente na exposição que apresenta uma carta de esclarecimento de Niemeyer junto a um croqui para o novo edifício do MAM-SP dentro do parque, e projetado por ele quando convidado a atualizar Plano Diretor do Parque do Ibirapuera, em 1996. Mas também pelo texto curatorial, no qual duas falas de Lina Bo Bardi revelam mais do que uma ambiguidade na fala da arquiteta que afirmara que se fosse ela "já havia pedido a demolição de tudo aquilo", mas que a "vivência popular' sempre supera 'o desenho da prancheta”" (BO BARDI apud LAGNADO, 2013, p.15). 
recém inaugurado, hoje Museu Pampulha. Fotografias que apresentaram ao mundo a relevância da arquitetura moderna brasileira e contribuiram para a constituição de uma identidade nacional, ainda que sua atualização pelo trabalho de Mauro Restife - que retrata cenas de fora do Palácio da Alvorada durante o velório de Oscar Niemeyer, em 2012 -, e de Yuri Firmeza e Amanda Melo da Mota <imagem C3.2 p.205> explicitasse as ambiguidades presentes no ideal moderno, que não ultrapassou os limites edificados para refletir na esfera pública princípios de transparência e neutralidade.

Mas é por meio da continuidade de uma pesquisa anterior de Lagnado sobre a figura do "artista-arquiteto"166 que a arquitetura manifesta-se de maneira mais marcante na exposição. Resgatado pela curadora em seu texto de apresentação, o “artista-arquiteto” seria aquele que, partindo das especificidades da formação em arquitetura, controlaria "ferramentas que transcendem a dimensão plástica” (LAGNADO, 2013, p. 19), e com isso poderia habilitar "uma visão crítica do significado de um espaço público e comum” (LAGNADO, 2013, p. 19). Este “artista-arquiteto” conseguiria provocar a prática artística em sua tensão com a realidade, assim como o seu avesso: convocar uma filosofia arquitetônica que antecede a edificação.

É desta tensão que deriva o convite dirigido a sete escritórios de arquitetura ${ }^{167}$ para que apresentassem especulações projetuais sobre uma nova sede para o MAM-SP como forma de explicitar a fragilidade das atuais instalações do museu no conjunto do Parque do Ibirapuera. Tal enunciado ancora-se na premissa de que um horizonte sem restrições, e sem a finalidade de uma real implantação, possibilitaria um exercício imaginativo que o aproximaria de uma natureza utópica artística.

A maior parte dos resultados que integram a exposição, no entanto, acabaram por reafirmar lugares consolidados. De um lado, desenhos e maquetes de futuras edificações

166 Pesquisa que fundamentou a mostra Desvios da deriva: experiências, travessias, morfologias (2012), realizada com curadoria de Lisette Lagnado no Museo Nacional Centro de Arte Reina Sofia, em Madri, presente no texto de mesmo título disponível em: https://www.museoreinasofia. es/sites/default/files/publicaciones/textos-en-descarga/12LL_es.pdf

167 São eles: Tacoa, Gruposp, Andrade Morettin arquitetos, Sbpr, SUBdv, Y arquitetura, e Usina. 
reproduziam a desconexão entre arquitetura e público, condição agravada pelos modos de representação em escalas distanciadas do corpo, que pouco exploraram a condição de liberdade proposta - situação que nem a realidade virtual foi capaz de superar. De outro lado, aos artistas coube um pensamento mais radical e crítico, capaz de se distanciar da necessidade de um edifício como catalizador da experiência de museu e mobilizar a imaginação sobre as possibilidades de explosão dos limites do Museu, ou do princípio do cubo branco isolado do mundo, para especular sobre possíveis convergências entre a instituição e o espaço, e entre museu e cidade.

Dois projetos foram mais propositivos nesse sentido: o primeiro, da Usina CTAH, e o segundo, do Gruposp. O primeiro utilizou a exposição para debater as contradições desse museu moderno, sua inserção no Parque e sua relação com a "metrópole truncada e incongruente" (USINA CTAH, 2013, p. 214), valendo-se, para isso, de oficinas realizadas durante a exposição com os públicos que frequentam o MAMSP e também com as equipes do próprio museu. Já o Gruposp devolveu a sede do MAM-SP ao centro da cidade, origem do modernismo paulistano e local onde o museu iniciou suas atividades em 1948, na sede dos Diários Associados, na Rua 7 de Abril. O Museu difuso e urbano (2013) compreendeu que o edifício deveria abrigar o acervo técnico e a área administrativa, de forma que as exposições pudessem se diluir pelo calçadão densamente ocupado, mesclando-se às lojas e espalhando-se pelos edifícios da região consolidada.

Essa possibilidade foi realmente vivenciada pela instalação dos trabalhos Postococa (2013) no qual Dominique Gonzalez-Foerster apropria-se do desenho dos postos de salvamento cariocas, projetados por Sérgio Bernardes, e os reinterpreta como um suporte para o poema beba coca-cola (1957), de Augusto de Campos, transformando-o em um totem-ponte entre Rio de Janeiro e São Paulo, inserido em meio à circulação pública do Ed. Galeria Nova Barão (1962); pela performance Parada pedra (2013), de Arto Lidsay, que desfilou pelo circuito do Museu Difuso; e pela Catarata (2013), de Federico Herrero <imagem C3.3 p.206>, que demarca o campo superior da empena que seria ocupada pelo MAMSP, pintando-a de um azul que ora a destaca em meio às intermináveis camadas de edifícios, ora a dissolve no céu de São Paulo.

Mas o Museu difuso e urbano é extrapolado por Pablo 
Leon de La Barra, que propõe a criação do Novo museu tropical (2013), um museu nômade, efêmero, sem acervo ou paredes, de baixo custo e ao alcance de todos. O "curadorartista", que trabalha com o reconhecimento e consolidação de redes de artistas na América Latina, apartadas da História da Arte "oficial”, apropria-se dos trechos de Arquitetura sem edifício (2012), de Yona Friedman. A colaboração entre La Barra e Friedman para a P33 explora as possibilidades de um museu diluído pelo país, atingindo locais distantes do circuito da arte, dialogando com "espectadores desinteressados"168, e visibilizando uma potente diversidade de produção e de agenciamentos possíveis.

Logo, se é a exposição que define o espaço do museu, a explosão de seus limites para territórios expandidos provoca um alargamento do panorama cultural como potencial para uma reconstrução, em outras bases, de uma nova história da arte. Essa uma questão fundamental para a produção de arte latino-americana a partir dos anos 1960 como agente precursor de experimentos “de arte na situação, de arte antiarte” (1965, p.9), como afirma Mario Pedrosa sobre a obra de Lygia Clark e Hélio Oiticica.

A radicalidade de Oitica e sua experiência no Morro da Mangueira, a partir da qual o artista elaborou sua diluição no mundo para dele se apropriar, convocando o público como participador, repercute em Novo Museu Tropical. Essa ação, nas palavras de Oiticica (1986, p.79), representa um "golpe fatal ao conceito de museu, galeria de arte etc., e ao próprio conceito de exposição. [...] Museu é o mundo".

Mesmo não tendo sido um golpe fatal, os conceitos de museu, galeria e exposição permanecem como objeto da investida artística diante da intensificação da diluição dos limites entre arte e vida pelas pós-vanguardas, com seus flagrantes rebatimentos no espaço expositivo. Assim, tendo em vista as aproximações entre arte e arquitetura, os projetos museográficos são cada vez mais convocados como camada infraestrutural essencial para a reflexão sobre os dispositivos

O “espectador desinteressado" é definido por Stephen Wright em consonância com o "espectador emancipado”, elaboração Jacques Rancière que trata da ruptura do distanciamento entre obra e espectador. O espectador emancipado pelo domínio da linguagem estaria implicado no jogo como um participante da ação artística. Wright sugere a substituição da palavra espectador por usuário, como chave de compreensão mais direta da proposição de Rancière. 
de exibição. Segundo Lagnado (2010, online),

Montar uma grande mostra coletiva de modo a dar sustento a uma narrativa é um tema que, nos últimos sessenta anos, se tornou central, com influências notáveis na agenda da museografia. Essa centralidade se deve à importância dada à percepção estética do público visitante, seja leigo ou não: arte contemporânea não se define apenas por uma eventual qualidade intrínseca dos objetos à mostra como numa feira de arte, mas pela sua capacidade de criar uma atmosfera, um ambiente. Sendo assim, desde a fixação das obras, sua altura na parede, cor dos painéis, distância entre as obras e distância das obras com o espectador, a iluminação, a informação gráfica... tantos detalhes que, sabemos, não são detalhes, são a alma da exposição.

No caso da P33, o projeto expositivo do arquiteto Álvaro Razuk <imagem C3.4 p.207> recupera as paredes escalonadas do salão expositivo principal e retoma a continuidade visual com o Parque do Ibirapuera pela sua fachada envidraçada à leste. Também evita a solução simplista e convencional de utilizar paredes autoportantes, divisórias opacas que compartimentam o espaço e barram uma deriva do olhar. $\mathrm{E}$ retoma, ainda que pelo curto período de sua exibição, a porta de entrada, pintada de amarelo, na extremidade em frente ao Pavilhão da Bienal, que segue permanentemente fechada sob justificativa de acondicionamento e segurança do principal salão expositivo do museu.

Assim, o projeto museográfico da P33 opera para além da sua condição secundária de pensar os suportes e distribuição das obras, propondo um "enunciado espacial" (LAGNADO, 2015, p.84) que se justapõe à narrativa curatorial e, neste caso, realiza-se como uma exposição do espaço do MAM-SP, tal como imaginado por Lina Bo Bardi <imagem C3.4 p.207>. 


\section{A Marquise, o MAM, e nós no meio (2018)}

Aprofundar questões originadas durante a $P 33$ e atualizá-las diante do uso cada vez mais intenso da Marquise, apropriada como espaço de manifestação simbólica e cultural da cidade, foi premissa e proposição da exposição A Marquise, o MAM, e nós no meio (2018), com curadoria de Ana Maria Maia em conversa com o Educativo MAM e O grupo inteiro ${ }^{169}$.

A investigação parte da formulação de que "o extracampo importa tanto quanto o que se vê"(MAIA, 2018, p.15). Uma afirmação que abre o texto de Maia sobre a exposição, intitulado "Autorretrato de mãos dadas com...” (2018), e faz clara menção a uma imagem do acervo. Trata-se de um intrigante autorretrato do fotógrafo Otto Stupakoff ${ }^{170}$, onde o vemos de mãos dadas com uma criança propositadamente deixada de fora do enquadramento. Ausência que inverte a lógica do autorretrato e desvia a atenção do protagonismo de seu autor.

Uma exposição de acervo pode, portanto, ser interpretada como uma espécie de autorretrato da instituição. E neste caso, assim como no autorretrato que a instiga, o extracampo pode informar tanto quanto o território conhecido e controlado do museu de arte moderna, com seus modos de exibição consolidados e baseados na lógica do cubo branco. Em vista disso, uma exposição de acervo pode reivindicar um olhar desviante, atraído para aquilo

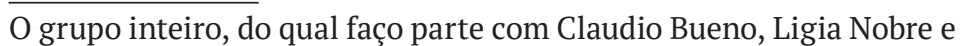
Vitor Cesar, foi formado em 2014 e reúne diferentes práticas e repertórios nos campos da arte, design, aprendizagem, arquitetura e tecnologia, na busca por uma multiplicidade de caminhos, instaurando condições de diálogos públicos informados por diferentes redes, plataformas e projetos, realizados por seus integrantes e colaboradores.

170 Autoretrato, Nova Iorque (1967) de Otto Stupakoff, integra o acervo do MAM, que possui uma relevante coleção de fotografias em seu acervo estimulada por um programa anual de aquisição que envolve proposições diversas que abarcam de registros de artistas à fotojornalismo. Essa coleção é apoiada pelo clube de colecionadores, e se divide em um clube de fotografia e outro de gravuras, e contemplando seus associados com reproduções das provas do artista que permanecem no acervo. 
que não é imediatamente visível, mas está enunciado, gerando rebatimentos nas diversas camadas que compõem a preparação de uma exposição.

A pesquisa e seleção de obras, por exemplo, pode retirar da reserva técnica uma seleção de pinturas, fotografias, gravuras, objetos e performances que revelem a existência de um conjunto menos homogêneo de arte contemporânea ${ }^{171}$ na coleção, demonstrando um viés de forte apelo ao imaginário pop. Do corpo do museu, podese destacar o vívido trabalho do Educativo e sua interface com o público conformada por uma história rica em práticas de escuta exercidas e consolidadas no dia a dia por meio de diálogos de dimensão pública.

E de forma inevitável, por se tratar de uma condição que se formula pelo espaço que escapa do enquadramento de uma fotografia, o extracampo recupera a noção de enunciado espacial nos termos explorados pela expografia da $P 33$, para tentar expandi-lo. A curadoria de Maia propõe pensar-se além das obras selecionadas, sua distribuição no espaço e sua justaposição ao discurso curatorial, e ensaia uma inversão que parte do entorno do espaço expositivo do museu para, a partir dele, alargar o contexto de atravessamentos de camadas físicas e discursivas. Reinterpretado com o distanciamento de cinco anos ${ }^{172}$, o enunciado espacial do MAM-SP demandou uma ruptura do enquadramento a galeria

Essa é mais uma das contradições históricas que conectam MAM-SP e MAC-USP, consequência da doação da coleção de arte moderna do MAM-SP por Cicillio Matarazzo, em 1963. Com isso, o Museu de Arte Contemporânea hoje detém uma importante coleção de arte moderna, enquanto o MAM-SP, que desde 1969 buscou reconstruiu um acervo, veio a constituir uma coleção predominantemente voltada à arte contemporânea.

Os cinco anos que separam as duas exposições, embora não seja longo período, apresentaram um desenrolar de fatos com significativa mudança no cenário político nacional, nas perspectivas sociais e no ânimo econômico, com impacto direto sobre o panorama cultural. Retomando o texto de apresentação de Maia, o período de trabalho e exibição de $A$ Marquise, o MAM, e nós no meio, entre setembro de 2017, quando se forma a equipe, e maio de 2018, quando foi inaugurada, é atravessado por uma sequência de fatos, alguns dos quais afetam diretamente o museu, como o anúncio de privatização do parque pelo então prefeito João Dória Jr., e uma falsa acusação que viraliza nos meios digitais, colocando o MAM-SP no centro de uma polêmica sobre uma criança exposta à nudez durante a performance do artista Wagner Schwarts, na abertura do $35^{\circ}$ Panorama da Arte Brasileira. Segundo Maia, "embora não tenham sido matéria para o projeto, esses e outros episódios certamente incidiram na conjuntura institucional e nas subjetividades de equipes e públicos, obrigando-os a lidar com sentimentos como incerteza, medo e reatividade" (2018, p.15). 
e sua pretensa neutralidade ${ }^{173}$ que legitima protocolos, age sobre os corpos, e seleciona públicos.

A Marquise, o MAM e nós no meio, como seu título enuncia, admite a história tortuosa do museu em busca de uma sede, para superá-la e enaltecer a singularidade de sua localização ${ }^{174}$. A Marquise é compreendida como um fluxo do qual o MAM-SP já participa ativamente, entre skatistas e dançarinos, assembleias, debates e manifestações das mais diversas. Menos do que uma nova sede, caberia ao museu reconhecer-se parte do mesmo piso contínuo e da mesma cobertura partilhada com o restante da Marquise, permeado por todos nós, atando e desatando os nós de sua convivência diária com os eventos e disrupções dali desencadeados.

Esse exercício de reconhecimento procurou suspender, ainda que temporariamente - ao longo dos três meses que durou a exposição, entre maio e agosto de 2018 -, o domínio do museu de arte moderna sobre o objeto artístico e sobre o visitante ${ }^{175}$, para se deixar arrebatar pelas disjunções da Marquise. As disjunções aqui são entendidas como um paralelo às discussões teóricas do arquiteto Bernard Tschumi, nos anos 1970, quando ele, por meio de textos e proposições gráficas, desafiou dualidades arraigadas do campo arquitetônico que atrelam forma e função, programa e contexto, estrutura e significado. Um sistema de oposições binárias que a característica polivalente da Marquise do Ibirapuera desmonta, interditando qualquer possibilidade de síntese, de controle ou determinação, como já nos

173 Basta pensar na frase “A pureza é um mito” presente em um dos penetráveis de Oiticica que compõem Tropicália (1967). A pureza é qualificada pelo artista como uma idealização, uma falsa representação a partir do estado atingido pela arte no século XX, que não admite "quaisquer ligações extraestéticas ao seu conteúdo” (OITICICA, 1988, p.53).

174 Segundo Ana Maria Maia, com quem conversei em 7 de outubro de 2019, durante os diálogos com os diversos artistas e arquitetos que problematizavam a condição do MAM-SP durante a P33, apenas o artista Daniel Steegmann recusou a postura de negatividade para afirmar o privilégio de ter um parque como Ibirapuera e a Marquise ao alcance do museu.

Thomas McEvelly, em sua introdução ao livro No interior do cubo branco de Brian O'Doherty, baseado em seu texto publicado na revista Artforum, em 1976, afirma que os preceitos que constituem a construção da galeria moderna excluem e isolam o mundo criando um “ contexto demasiado orientado da galeria modernista sobre o objeto artístico, sobre o visitante e, num momento crucial para a arte moderna, como o contexto se apodera do objeto, tornando-se ele próprio” (2002, p.XV). 
demonstravam os desenhos diagramáticos de Eduardo Gurian $^{176}<$ imagem C3.1 p.204>.

Esses eventos espontâneos,

[...] produzem sistematicamente a dissociação no espaço e no tempo, em que o elemento arquitetônico somente funciona por meio da colisão de um elemento programático com o movimento de corpos ou coisas do tipo (TSCHUMI, 1988, p.191).

É justamente da energia gerada pela colisão de "corpos e coisas do tipo" com o programa "museu de arte moderna" que se extrai o impulso para a pesquisa de A Marquise, o MAM e nós no meio, sugerindo um raciocínio inverso ao pressuposto de se selecionar e mostrar obras do acervo como fundamento de dentro para fora: do museu para o mundo.

Por meio de um movimento contrário, buscou-se abrir passagens para que o fluxo dos públicos que utilizam os espaços adjacentes ao museu, como lugar de afirmação de identidade e expressão cultural, pudessem permear as superfícies que os separam e se reconhecerem também dentro do museu.

As demandas por uma interface entre museu e público hoje superam as habilidades de resposta dos marcos referenciais Spider [Aranha] (1996), de Louise Bourgeois, que de sua redoma envidraçada ${ }^{177}$ olha ao longe e recepciona encontros, ou do grafite OSGÊMEOS(2010) que, ao lado da entrada do museu, angaria selfies. Ambos flertam com o público do parque, mas não promovem passagens. É da porta contígua à Aranha, que se abre para a realização dos

O recorte escolhido do desenho de Gurian para ser apresentado aqui, propositadamente mostra o trecho ocupado pelo MAM-SP como um espaço branco e vazio cercado por situações variadas, graças às decisões de representação gráfica que o orientaram. Apenas a Aranha é representada, mas sua redoma desaparece como superfície. Segundo o arquiteto, as regras estabelecidas foram: "nunca desenhar bordas, deixar os programas determinados em branco, desenhar a vegetação como textura e os pilares como a sombra que projetam, para que por contraposição os campos formados pelos corpos se destacassem" (em conversa com o arquiteto, no dia 13 nov. 2019).

A área envidraçada foi construída numa expansão do museu, em 1998, especificamente para abrigar a exposição permanente de Spider[Aranha] (1996) quando de sua aquisição pelo Banco Itaú, após a obra participar da 23ª Bienal de São Paulo, em 1997. 
Domingos $\mathrm{MAM}^{178}$, que trânsitos mais intensos ocorrem.

O programa Domingos MAM surge em 2013, diante do agravamento de situações de risco envolvendo violência e alcoolismo por parte do público jovem. Esses episódios, que passaram a interpelar o museu, representam um momento de inflexão essencial, no qual o Educativo ganha protagonismo e estabelece uma significativa ponte capaz de dar vazão à energia das manifestações e comportamentos de sua vizinhança, construindo uma relação baseada na troca e na atenção às manifestações socioculturais em toda sua diversidade.

Coube a Maia, portanto, como membro do Conselho Consultivo do museu e convidada a desenvolver essa curadoria, ter a sensibilidade de juntar as pontas soltas, distribuir o conteúdo, embaralhar os papeis, e partilhar as inquietações, constituindo um processo transversal de criação que envolveu conversas internas e externas com o educativo do MAM-SP e O grupo inteiro - que se tornaram coautores do projeto à medida que suas práticas se entrecruzavam. Curadora, educativo, e artistas-arquitetos passaram, conjuntamente, a agenciar uma sequência de torções na estrutura da produção, ampliando seu escopo para um exame dos dispositivos que mobilizam o corpo e o espaço para além da condição de apoio da camada discursiva que se debruça apenas sobre os trabalhos do acervo.

A equipe apostou na afirmação da diversidade dos públicos que hoje passam pelo MAM-SP, mas que não necessariamente entram no museu. E assumiu os riscos de provocar cruzamentos entre os grupos que frequentam o Ibirapuera e o museu, construindo um programa público de eventos que pudessem acontecer dentro e fora da sala Paulo

O programa Domingo MAM propõe atividades diversas com o intuito de criar um espaço de relação e pertencimento com os frequentadores do Parque Ibirapuera, particularmente com o público jovem. Sua programação gratuita, sempre aos domingos, envolve dança, música, cultura de rua e oficinas. Segundo sua coordenação, essas atividades expandem os sentidos do museu por meio do contato com as pessoas que dele participam. 
Figueiredo ${ }^{179}$ e da sala de vidro ${ }^{180}$ utilizadas pela exposição.

Para tanto, o projeto expográfico promoveu uma limpeza, de modo que se reconstituíssem os acessos diretos desta galeria com a sala do educativo e com a sala de vidro. Foram removidas as divisórias temporárias que se acumulam a cada exposição, fechando os acessos e bloqueando o contato visual com o exterior e cujo intento é isolar o espaço de qualquer interferência.

A partir daí, o desafio de romper com protocolos de comportamento e controle dos corpos, reiterados pela museografia convencional, passava por garantir as condições de segurança para exibição das obras, ao mesmo tempo que se propunha a encorajar outras posturas e usos no interior da galeria. Ou ainda, criar ambiguidades com os anteparos que estabelecem a distância entre espectador e obra (fitas, distanciadores etc.) ressignificados como Obstáculo (2018) <imagem C3.5 p.208>, obra produzida para a exposição e utilizada para prática de dança, skate, parkour, ou outros jogos, quando deslocadas para a Marquise durante os Domingos MAM.

Ao serem destacadas de suas bases, essas peças deixavam como rastro um campo de cor preta, um negativo demarcado nas paredes da galeria <imagem C3.5 p.208>. Indícios de sua existência, quando ausentes, voltavam a ser ocupados por peças riscadas e marcadas pelo uso, constantemente rearranjadas conforme o desejo de

A Sala Paulo Figueiredo faz parte de uma das ampliações do projeto original de Lina Bo Bardi, realizada em 1995 pela arquiteta Maria Lucia Pereira de Almeida. Essa reforma expandiu a área do museu com essa segunda galeria, de menor porte, e com a construção do restaurante, alterando o auditório, o acesso principal e a distribuição dos espaços (MAIA, 2013, p. 37). O memorial descritivo do projeto do Gruposp para exposição P33 faz uma justa e dura crítica a esse projeto que descaracterizou o volume do MAM deixando-o "eclipsado por um restaurante” (GRUPOSP apud MAIA 2013, p. 2016).

Aranha, que integrava a lista de obras da exposição, passou por um restauro para lhe garantir melhor estabilidade. Em razão de um atraso, deixou sua sala disponível para ser usada durante A Marquise, o MAM e nós no meio, recebendo o Café Educativo: uma escuta da fome (2018), de Jorge Menna Barreto, e Teia (2018) d'O grupo inteiro, um painel que inventava, com o uso das palavras, diferentes encontros entre os públicos e objetos da marquise, do museu e do parque, ficando visível para quem estava do lado de fora, e gerando também certo flerte e interface com um projeto que desejava se comunicar com esses públicos. Teia conviveu com Aranha durante quinze dias, após ter retornado restaurada para a celebração de 70 anos do MAM-SP. 
convivência, e intensamente utilizadas dentro e fora da galeria. Ao desempenharem seu papel de suporte de uma forma amplificada, Obstáculo alterou pontos de vista, regulou proximidades e estabeleceu contato entre público, obras e eventos, como a performance BeyHives <imagem C 3.6 p.209> - pelo fã clube performático da cantora Beyonce -, as batalhas de break e de vogue ${ }^{181}<$ imagem C 3.6 p.209>, as manifestações do coletivo LGBTQI+ A revolta da lâmpada e do grupo de secundaristas egressos que formaram o coletivA ocupação e apresentaram a peça Quando quebra queima (2017) <imagem C 3.6 p.209>.

Operações como essa foram arquitetadas por meio da identificação e ocupação de brechas ${ }^{182}$ manejadas como ações micropolíticas a partir do sistema do museu e de suas infraestruturas. Servem como exemplo o tratamento dado à lista de $\operatorname{artistas}^{183}$, que equiparou eventos às obras de acervo, artistas da coleção aos grupos convidados, ou a ficha técnica que diluiu as categorias curadoria, expografia, linguagem e proposições artísticas, como reflexo da estanqueidade dos modos de operar das instituições de arte. Ou ainda a maneira de elaboração das legendas de obras, com a participação do público e ao longo da exposição, como "uma narração heterogênea e, ainda assim, corresponsável” (MAIA, 2018, p.16).

A característica “indisciplinada” da exposição parte de um grupo curatorial que admitiu conviver com incertezas para produzir uma reflexão sobre o papel hierárquico do museu moderno como “depósito de saber ordenado em

Competição de dança caracterizada pelas poses estilizadas de seus participantes.

182 Segundo Stephen Wright, em Para um léxico dos usos, "as brechas são a quintessência das táticas que os usuários põem em prática, já que abrem vias de entrada em um sistema sem danificá-lo materialmente", mas se aproveitam de suas zonas cinzentas para rebater obliquamente às expectativas (WRIGHT, 2016, p.33).

A lista de obras e eventos incluiu: Alessandra Leão, Amelia Toledo, BeyHive, Breaking lbira, Racha Show, Cinthia Marcelle, Claudio Tozzi, Coletivo ocupação, Explode!, MC Dellacroix, Falves Silva, Flávio de Carvalho, Georgete Melhem, Guilherme Peters, Henrique Fuhro, Rough, lone Saldanha, lvens Machado, JAMAC. Jorge Menna Barreto, Laura Lima, Lenora de Barros Manuk Poladian, Mário lshikawa, Maureen Bisilliat, Micrópolis \& Ariana Miliorini , Mídia Ninja , Mônica Nador , Nair Benedicto , Nenê da Vila Matilde , O grupo inteiro, Otto Stupakoff, Paulo Nazareth, Revista on/ off (Regina Silveira e Julio Plaza org.), Rosana Paulino, Siron Franco, Vilma Slomp, Waldeny Elias (MAIA, 2018, p.185). 
categorias conhecidas e aceitas” (ALLEN, 1999, p. 101) e, quem sabe, pensá-lo como campo expansível e aberto, acolhendo mudanças de baixo para cima, de fora para dentro, e ao longo do tempo.

A esse respeito é oportuna a reflexão do arquiteto Stan Allen:

Quando os papeis sociais, políticos e técnicos dessas instituições são questionados, as tipologias correspondentes perdem sua capacidade de ordenar e representar o espaço que elas ocupam. [...] A capacidade da arquitetura em representar e abrigar essa memória coletiva ficou debilitada. Hoje projetar uma biblioteca ou um museu é um conjunto inteiramente novo de expectativas. Significa acima de tudo reconhecer uma incerteza cada vez maior sobre o que é o conhecimento, quem tem acesso a ele e como está distribuído.

(ALLEN, 1999, p. 101)

A relação imbricada entre tipologias e seus princípios organizacionais em estado de atrofia, como nos coloca Allen, poderia ganhar com ajustes mais maleáveis das diferentes atividades e suas relações com indivíduos e discursos presentes no espaço e manifestos por meio do espaço.

A Marquise, o MAM e nós no meio, em sua pequena escala, questionou os discursos normativos que cruzam essas estruturas e provocou, por meio de seu enunciado espacial e programação, outras formas de produzir repertórios e sentidos dentro de um museu. Para tanto, procurou distribuir valores ${ }^{184}$, tendo em vista o quanto museus "influenciam o perfil educacional e socioeconômico de quem nele existe enquanto propositor, audiência, e ainda os que estão ausentes” (MAIA, 2018, p. 17) ${ }^{185}$. Este processo seletivo e naturalizado representou um desafio no sentido de respeitar e cuidar para que processos colaborativos,

184 Valores simbólicos, mas também os monetários. Agindo sobre planilha de produção da exposição, foi possível manejar quantias de forma a favorecer uma distribuição dos recursos e contemplar o trabalho dos grupos que integraram a programação dos Domingo MAM nós no meio.

185 É necessário pontuar que houve uma atenção e cuidado para que os processos colaborativos, abertos e inclusivos, não incorressem numa prática de validação e enquadramento das manifestações espontâneas e dos grupos participantes por parte do museu. 
abertos e inclusivos não incorressem numa exotização dos grupos participantes, nem numa tentativa de validação e enquadramento, por parte do museu, das manifestações espontâneas.

Apesar dos engessamentos que enrijecem programações e instituições de arte, os museus podem ainda ser considerados espaços maleáveis para que se testem limites e se somem capacidades partilhadas pela arte e a arquitetura na elaboração de práticas que redefinam as partes e as relações entre elas. Nesse sentido, diante de um campo mais amplo e flexível, com permanências transitórias e abertura para programações temporárias, a arte tem favorecido experimentos que formalizam hipóteses espaciais que se manifestam física e discursivamente.

Basta pensar em outras experiências correlatas, como O outro, o mesmo (2011) <imagem C3.7 p.210>, no qual o arquiteto mineiro Carlos Teixeira desenvolveu peças em papelão corrugado que público e artistas rearranjaram no térreo do pavilhão da Bienal durante a $29^{\text {a }}$ Bienal de São Paulo. Ou a Estrutura suporte ${ }^{186}$ (2003-2005) <imagem C3.8 p.211> de Celine Condorelli, pensada como um sistema expositivo variável e indeterminado, entre arte e arquitetura. A depender de seu uso e da programação designada pelo "curador do dia”, durante uma exposição chamada Eu sou um curador (2003), a Estrutura suporte pretendia revelar, por meio de suas configurações, a expressão física de seu manuseio, e assim evidenciar o processo e suas interfaces.

A natureza destes exemplos coloca luz também sobre como essas hipóteses espaciais catalisam processos e propiciam a elaboração de conteúdos discursivos, um recurso que contesta o insuperável antagonismo da não correspondência entre teoria e prática na arquitetura.

186 Livre tradução do termo Support Structure, título da obra e questão que atravessa de maneira transdisciplinar o trabalho dessa arquiteta de formação, que em sua pesquisa publicada no livro Suport Structures (2014), afirma a necessidade de "nos livrarmos de algumas noções: por exemplo, que o que valida um assunto deve ser constituído por um objeto de pesquisa, pertencer a um campo disciplinar ou traduzir um conjunto distinto de entidades”(CONDORELLI, 2014, p.10). 


\section{O Vão Livre do MASP}

Pensar uma arquitetura conectada à cidade é um desafio projetual crucial para um edifício de interesse público, particularmente um museu e sua vocação de caráter monumental. No entanto, no caso do Museu de Arte de São Paulo (MASP-1968), projeto de Lina Bo Bardi, o Vão Livre não só dilui a importância do objeto arquitetônico sem abrir mão de sua monumentalidade ${ }^{187}$, como o subordina a um espaço projetado de maneira radicalmente aberta, graças ao grau de indeterminação que deixa para sua futura ocupação.

É essa ocupação coletiva que a arquiteta enfatiza quando afirma:

[...] o que eu quero chamar de monumental não é questão de tamanho ou de 'espalhafatoso', é apenas um fato de coletividade, de consciência coletiva. O que vai além do 'particular', o que alcança o coletivo, pode (e talvez deve) ser monumental. (BARDI, 1967, p. 20)

Disponível para dinâmicas complexas, o vão flerta com o acaso, os acontecimentos e as situações que atravessam o museu, tendo se tornado outro exemplo de apropriação referencial para São Paulo. Trata-se de um espaço que concentra importantes manifestações políticas e culturais que irradiam da cidade e interpelam o museu e sua história, proporcionando um contexto único.

De fato, podemos entender o museu, dividido ao meio pelo Belvedere, como se fossem dois blocos, um sob seu piso, outro suspenso pela estrutura de concreto protendido. Dos dois níveis suspensos resulta a forma reconhecida e marcada

Questão crucial para os Congressos Internacionais de Arquitetura Moderna no pós-guerra, a ruptura com os paradigmas funcionais da Carta de Atenas tendo as associações humanas como elemento central para uma abordagem de cidade cuja escala e programas fossem voltados para pessoas é patente na maneira como Lina Bo Bardi ressignifica a noção de monumentalidade. 
pelos dois pórticos vermelhos, que vencem os 74 metros de vão, enquanto os dois níveis abaixo acomodam- se ao terreno, originando o grande terraço.

Destinado a ser um logradouro público desde o loteamento da Avenida Paulista, no começo do século XX, característica potencializada pelo projeto de Lina Bo Bardi, o Vão Livre, hoje, se apresenta como desafio para que o MASP estabeleça conexões mais francas com a diversidade cultural que o habita - ainda que, desde a criação do museu, em 1949, o casal Bardi se orientasse para uma abertura ao diálogo amplo e acessível com a sociedade. Nas palavras de Lina Bo Bardi:

A ideia de museu é das que se acham mais entrosadas na mentalidade das pessoas com a ideia de mausoléu intelectual, o que se deve entender como fruto particular da organização dos museus instalados na base da conservação e da especialização em que se fecham as coleções em um edifício[...] sufocadas sob as cúpulas, as escadarias monumentais, os salões cheios de colunas, tornando-se assim uma embaraçosa superfluidade. (BARDI, L. 1950, p. 17) 188

Para entender as contradições e contingências que informaram o projeto, bem como as negociações políticas que até hoje influenciam a gestão e regulação do vão, pertencente à prefeitura municipal de São Paulo, a recente pesquisa do historiador italiano Daniele Pisani ilumina detalhes sobre a origem do partido incomum que caracteriza o museu e marca a Avenida Paulista. Sua investigação apoia-se numa extensa documentação do acervo público do município, até então inédita e jamais cotejada, explicitando aspectos da longa e tortuosa negociação ${ }^{189}$ para obtenção da cessão de uso do terreno para o MASP. Sua principal

188 Texto que Lina Bo Bardi escreveu e publicou na primeira edição da revista Habitat. Importante lembrar que o MASP é fundado em 1949 sobre um tripé de ação conjunta, com vistas a constituir um contexto cultural ampliado. Assim, além da coleção de arte, foi lançada a revista Habitat voltada para arte, arquitetura e cultura, e foi criada a escola de arte e desenho industrial - o Instituto de Arte Contemporânea (IAC).

189 O Trianon do MAM ao MASP. Arquitetura e política em São Paulo 19431968 (2019), de Danieli Pisani, passa a limpo toda a história do lote hoje ocupado pelo MASP, e que ao longo dos anos 1950 foi cobiçado por Cicillio Matarazzo para a instalação de um equipamento cultural, mas que teve inúmeras propostas de projeto e usos como teatro, museu de arte moderna, salão de baile e pavilhão de exposições. 
tese, comprovada pelos documentos, contesta a versão consolidada de que o Vão Livre é consequência de restrições legais que determinavam a manutenção da vista em alusão ao histórico Belvedere projetado por Ramos de Azevedo, na década de 1920.

Embora houvesse um consenso sobre certas condições a serem observadas - por exemplo, garantir um sistema estrutural independente do túnel da Avenida 9 de Julho ${ }^{190}$ que corta o terreno, e a manutenção do mirante que conecta visualmente o parque Trianon e o Vale do Anhangabaú, intenções perseguidas em maior ou menor grau por projetos anteriores ${ }^{191}$-, não existe, segundo Pisani, um único documento que comprove a condição de se manter o Belvedere do Trianon como espaço vazio com a vista preservada, exceto os depoimentos enviesados e endossados pelos envolvidos no projeto do Masp, principalmente por Pietro Maria Bardi ${ }^{192}$, diretor artístico do museu.

A versão consolidada como oficial se apoiaria numa falsa questão cujo intuito seria escamotear interesses e

O Instituto de Pesquisas Tecnológicas (IPT) é acionado tanto em 1951, a pedido de Cicíllio Matarazzo, quanto em1956, quando a prefeitura retoma projetos para a área, e, ainda que de maneira incipiente, tem seu interesse confirmado "pelo fato de os técnicos da prefeitura começarem a levar em conta os eventuais problemas relacionados às fundações por causa da presença do túnel (retomado relatório no 1905 do IPT)" (PISANI, 2019, p. 161).

191 Desde versões anteriores, quando ainda se intencionava transferir para aquele terreno o Teatro Brasileiro de Comédia, recuperar o salão de baile ou construir o edifício definitivo do MAM, a vista era uma questão considerada, mas sempre permitida através de pilotis e outros elementos de circulação que ocupavam o chão. Nas diversas versões de projetos, fica também evidente que Cicillio se articulava politicamente e especulava construir no terreno que havia acolhido o pavilhão temporário da I Bienal de São Paulo, em 1951, com autoria de Luis Saia. São de 1952 o projeto do arquiteto Mieczyslaw Grabowsky, que trabalhava para os Matarazzo (PISANI, 2019, p. 20-25), a versão para um edifício que sediasse “manifestações artísticas” de José Augusto Belluci (PISANI, 2019, p. 41) e mais conhecido entre eles, o projeto de Affonso Eduardo Reidy, publicado na revista L'Architecture D'Aujurd' hui como um Museu de Artes Plásticas a ser construído em São Paulo (PISANI, 2019, p. 13-19), depois nomeado de Palácio das Artes (PISANI, 2019, p. 117). Segundo a tese de Pisani, esse projeto seria abandonado após longa negociação simplesmente por não ter sido possível angariar os recursos necessários para a sua construção.

192 Embasado pela documentação, Pisani (2019, p.185) afirma que “Bardi, não raro, manipula a verdade, omitindo o que deseja que o leitor ignore, e sugerindo, pelo contrário, uma versão dos fatos que lhe seja mais conveniente”. Segundo autor, os projetos que a prefeitura vinha desenvolvendo para recuperação do salão de baile e do belvedere previam, inclusive, a construção de pavilhão que ocupava boa parte do terreno. 
acordos políticos. Uma explicação que acomodava a opinião pública, oferecendo uma justificativa plausível para o alto custo de investimento na construção de um edifício que representava uma 'excentricidade arquitetônica'193. Portanto, "Lina contou o próprio projeto como mera consequência de uma restrição legal - ao contrário daquilo que foi na verdade: a brilhante escolha de um partido" (PISANI, 2017, p. 7).

Essa versão dos fatos nos permite sublinhar a intenção da arquiteta de criar um espaço público ${ }^{194}$ extraordinário.

A pesquisa também esclarece que a solução em dois blocos permitia uma flexibilidade de ocupação que acomodava os interesses das partes envolvidas ao longo da truncada negociação. Enquanto o edifício era construído, havia uma previsão de ocupação repartida, na qual os dois andares do bloco superior seriam destinados ao MASP, enquanto os níveis sob o Belvedere seriam destinados ao hall cívico e a outras demandas da prefeitura de São Paulo, prolongando a disputa pelo espaço até que fosse ocupado definitivamente pelo MASP, após sua abertura.

No entanto, o anseio legítimo em projetar um espaço de liberdade, um vazio que não estivesse submetido a um programa ou a exigências funcionais, está presente em diversos momentos na fala de Lina Bo Bardi, assim como seu desejo de que este espaço fosse também utilizado pelo museu. No memorial descritivo do projeto, apresentado para a prefeitura, em 1957, Lina menciona que, “ao nível da Avenida Paulista, está previsto o espaço para colocação de obras de Arte"(BARDI, L. apud PISANI, 2019, p.168).

Dez anos mais tarde, quando Roberto Burle Marx é convidado a redesenhar o Parque Siqueira Campos, do

193 E ainda alimentava a vaidade de Bardi, desafeto de Cicillio Matarazzo. Bardi se vangloriava por ter vencido a disputa pelo terreno, tendo respondido corretamente às condições desconsideradas anteriormente, o que a documentação comprova ser uma mentira, uma vez que "o MASP entra em cena quando o MAM já havia desistido por falta de tempo e dinheiro. [...] e não pelo fato de um oponente possuir informações que o outro ignorava” (PISANI, 2019, p.197).

194 Essa, sim, uma condição presente no documento de aquisição do terreno pela prefeitura, em 1911. De acordo com correspondências e o documento de compra do terreno pela Prefeitura de São Paulo - e não de doação como na versão dos Bardi -, a real restrição existente era quanto ao uso "destinado a logradouro público perpétuo" (PISANI, 2019, p. 200), possibilitando interpretações que não determinam nem explicam de maneira incontestável a solução adotada. 
outro lado da Avenida, e promover uma integração com o museu, sem que Lina fosse consultada, ela lhe escreve em uma carta: "o belvedere do Trianon, instalado na cobertura do grande hall cívico, será uma praça, sem jardim nenhum, para reuniões populares, exposições ao ar livre e concertos gratuitos. Nada mais” (BARDI, L. apud PISANI, 2019, p.178). No mesmo ano, na revista Mirante das Artes, Lina Bo Bardi comenta:

Procurei recriar um 'ambiente' no Trianon. E gostaria que lá fosse o povo, ver exposições ao ar livre e discutir, escutar música, ver fitas. Até crianças ir brincar no sol da manhã e da tarde. E retretas. Um meio mau gosto de música popular, que, enfrentado 'friamente' pode ser também um 'conteúdo'. (BARDI, L. apud FERRAZ (org.), 2015, p. 12)

Um depoimento que demonstra sua visão de abertura irrestrita, com disposição para a espontaneidade, para as práticas e convívios diversos, mesmo que representassem conteúdos idealmente indesejáveis.

Em seus desenhos, como Museu de arte de São Paulo. Perspectiva indicando ocupação do Belvedere com esculturas (1957-68) <imagem C3.9 p.212>, vemos esculturas ocupando o vão em uma grande exposição, enquanto em Estudo preliminar - Esculturas praticáveis do Belvedere do MASP (1968) <imagem C3.9 p.212> elas se espalham também rumo ao mirante do Vale, cercada por crianças que as utilizam, borrando definições que diferenciam o comportamento perante brinquedos e obras de arte. São desenhos que reiteram a ideia de museu proposta pelos Bardi, expandindo seu domínio para além do edifício, das galerias e do acervo, enfatizando a importância deste espaço pensado como chão comum partilhado com a cidade. Um espaço habitado e imbuído de um papel pedagógico emancipador ${ }^{195}$, que

É sabido que Lina Bo Bardi não interrompia seu trabalho projetual com o início das obras, transferindo seu escritório para o canteiro de obras para que projeto e programa fossem trabalhados de modo simultâneo (FERRAZ, 2008, online). Do mesmo modo mantinhase próxima das instituições que ajudou a construir, estendendo seu trabalho também para a programação dos espaços que criava, a exemplo de várias exposições no MASP, ou Mais de Mil Brinquedos para a Criança Brasileira (1982/2013) montada na área de convivência do SESC Pompéia no ano de sua inauguração. 
pudesse romper as barreiras que distanciam o público, oferecendo uma possibilidade de "aproximação com o museu gradual e por outras vias” (PROENÇA, 2016, p.15).

O Estudo preliminar - Esculturas praticáveis do Belvedere do MASP possibilita também se deduzir que, a um ano da inauguração, era flagrante que se planejava ocupar o Vão Livre com exposições e eventos. O que de fato ocorre durante a inauguração do MASP, em 1969, com a tríade de exposições montadas nesta ocasião: $A$ mão do povo brasileiro no primeiro andar, a coleção de arte do museu na pinacoteca do segundo andar, com os cavaletes de concreto e cristal, e a exposição Playgrounds composta por trabalhos interativos de Nelson Leirner no Belvedere.

\section{Playgrounds (1969)}

Nelson Leirner, artista afeito aos trocadilhos de tradição duchampiana, chamava atenção, naquele período, em razão da repercussão polêmica de suas ações. Experimentando com a noção de jogo, o artista implicava o público e a crítica direta e ativamente em seus happenings.

Entre 1967 e 1968, Leirner tinha, em ao menos três ocasiões - o Encerramento da Rex (1967), o Happening da Crítica (1968) e Bandeiras na Praça (1968) ${ }^{196}$-, deslocado seu trabalho para um embate de ideias num jogo discursivo através do qual reverberava seus lances estratégicos de modo a desconcertar todo aparato institucional da arte. Estratégia de "avacalhação que sempre fez com seriedade e método" (FARIAS, 2005, p. 16), colocando em xeque a aura mítica do artista, o valor da obra de arte e sua absorção pelo mercado, assim como o papel de legitimação desempenhado pela

196 Os três happenings integram o catálogo da exposição Playgrounds (1969), de Nelson Leirner, e são apresentados pelo artista com os nomes aqui citados. O catálogo é composto por cartelas impressas em duotone, com nove figuras destacáveis em cada cartela, sugerindo a manipulação do público como extensão das proposições em exibição. As figuras destacáveis mesclam fotos dos trabalhos apresentados na exposição Playgrounds com outras ações anteriores do artista, dentre as quais as três aqui indicadas. Disponível para consulta no Arquivo de Referência da Exposição Playgrounds no Centro de Pesquisa do MASP. 
crítica, pelos curadores e os museus.

Com Happening da Crítica, o artista constrói o trabalho a partir do envio e aceite da obra Porco com presunto para o Salão de Brasília, em 1967. O porco empalhado funcionou como pretexto para que o trabalho acontecesse no campo que de fato interessava a Leirner, a discussão sobre os critérios de escolha do júri ${ }^{197}$, que foi interpelado pelo artista a se posicionar publicamente com uma carta publicada no Jornal da Tarde com o título Qual o critério? (1967).

Para o Encerramento da Rex, que aconteceu em 25 de maio de 1967, Leirner convidou o público para uma exposição individual sua, à qual deu o nome de Exposição não-exposição, marcando o encerramento das atividades da Rex Gallery \& Sons (1967-1968), criada em parceria com Wesley Duke Lee, Geraldo de Barros, Thomaz Souto Corrêa, Frederico Nasser, Carlos Fajardo e José Resende - o Grupo $\operatorname{Rex}^{198}$.

O convite, publicado no jornal, convocava: "pare... olhe... entre... pegue (um happening não explica o que acontecerá)"199 - ou seja, tudo o que estava pendurado, embora estivesse acorrentado ou chumbado às paredes, foi arrancado em minutos por uma massa ensandecida, que levou inclusive uma série premiada na IX Bienal de Tóquio, colocando-se, na sequência, na frente da galeria e negociando as obras com quem chegasse. Ou seja, uma total desvalorização do especialista e do mercado de arte diante da livre negociação e consumo dos trabalhos pelo público.

197
“Dos cinco membros do júri, apenas Clarival do Prado Valadares não respondeu. Walter Zanini enviou uma carta oferecendo-se a responder publicamente caso os outros membros do júri assim concordassem. Mario Barata escreveu uma carta ao editor do Jornal da Tarde, em tom irritado. Mario Pedrosa publicou, em 11 de fevereiro de 1968, no jornal Correio da Manhã, o artigo ‘Do porco empalhado, ou os critérios da crítica'; enquanto Frederico Morais publicou dois artigos a respeito” (LOPES, 2011, p. 35).

"O Grupo Rex foi uma iniciativa de seis artistas unidos em torno do projeto de uma galeria, a Rex Gallery and Sons, com a intenção de intervir no circuito de arte, assim como de questionar a relação entre a arte e o campo cultural. [...] Para cada exposição é publicado um jornal, o Rex Time, distribuído na própria galeria. Marcada por irreverência e humor, a atuação do grupo busca novas formas de apresentação da arte (sempre em processo), bem como outros tipos de comunicação com o público, em franco embate com o circuito tradicional do mercado e das mostras de arte e com a crítica de arte dominante" (FERREIRA; COTRIM, 2006, p. 152-153).

Convite da exposição endereçado a Pietro Maria Bardi. Arquivo de referência, Nelson Leirner, Centro de Pesquisa do MASP. 
Já em Bandeiras na Praça (1968) <imagem C3.10 p.213>, junto com Flavio Motta, Leirner leva para uma esquina movimentada, em plena véspera de Natal, um conjunto de bandeiras produzidas por eles com temas populares, até terem todo o material apreendido pelo "rapa". Deflagram, com essa ação, um debate sobre o espaço público, cultura popular e públicos da arte, mais uma vez utilizando a imprensa como meio de interlocução para sua crítica.

É notório, por essa pequena amostragem, que as provocações de Leirner no mínimo o gabaritavam como um artista predisposto a experimentações fora dos enquadramentos institucionais convencionais, podendo responder à altura da exposição que inauguraria o museu, ocupando o Belvedere. Um alinhamento que ressoava a convocação de Lina Bo Bardi ao "choque" como disparador de "reações de curiosidade e investigação" (BARDI, L., 1950, p.17) no texto com tom de manifesto publicado na primeira edição da revista Habitat, O Museu de Arte de São Paulo Função Social dos Museus (1950).

Sobre o convite a Leirner, Pietro Maria Bardi afirma:

$$
\begin{aligned}
& \text { A intenção da apresentação dos objetos de } \\
& \text { Nelson Leirner no Belvedere do Museu era a da } \\
& \text { comunicação com o público, não platonicamente, } \\
& \text { mas direta, tão direta que sugeria, solicitava } \\
& \text { mesmo, uma participação tanto mental quanto } \\
& \text { táctil, manual, dando-se a liberdade de neles se } \\
& \text { mexer, modificar suas posições em composições e } \\
& \text { ajeitamentos que melhor agradassem ao visitante. } \\
& \text { (BARDI, P. 1969, datilografado, Centro de Pesquisa } \\
& \text { do MASP) }
\end{aligned}
$$

Playgrounds (1969) <imagem C3.11 p.214> consistia em um conjunto de aproximadamente 30 trabalhos que instigavam a interação por meio da manipulação dos objetos ali dispostos e convidavam o público passante a se envolver com a exposição, reforçando o caráter de extensão da rua exercido pela continuidade do piso que se expande sob o MASP.

Dentre as novas peças, trabalhos já conhecidos estavam dispostos para "encher o espaço" do vão, como $O$ porco (1966) empalhado, Matéria e Forma - tronco e cadeira (1965), um tronco de árvore marcado pela extrusão do perfil de uma cadeira, que ressurgia aplicada a uma altura que fazia com que crianças escalassem a peça para nela se sentarem, 
Adoração - altar para Roberto Carlos (1966), um neon de Roberto Carlos cercado por imagens de santos católicos sob o qual almofadas possibilitavam ajoelhar-se - tudo envolto por uma cortina com uma catraca na frente. Junto com esses trabalhos, um conjunto de novos objetos implicava o corpo e instava o uso espontâneo de quem passasse pela Avenida Paulista. Eram peças de madeira pintada, caixas de areia com bolinha de gude, flores de plástico e ferraduras, tendas de pano com formas destacáveis com zíper, e outros volumes geométricos que se encaixavam, como pirâmides e colunas de madeira, alguns fixos e outros apoiados em rodízios sobre um tablado liso para que pudessem ser deslocados.

Todos foram intensamente manuseados e reorganizados em diferentes composições. Leirner ressalta que não havia, na época, uma preocupação com o valor dos trabalhos:

Não tinha esse aspecto de arte de hoje. As bolinhas de gude nas caixas esvaziavam depois de duas horas [...]. A gente comprava sacos de bolinha muito barato, então era mesmo para o pessoal levar [...]. Não tinha importância se era destruído ou não. Foi destruído por uma razão política. (LEIRNER; PEDROSA, 2016, p. 38)

Atacada pelo Comando de Caça aos Comunistas durante a noite ${ }^{200}$, a exposição amanheceu sem condições de ser restaurada, apesar do esforço do Museu em recompor os trabalhos ${ }^{201}$. Um dramático e evidente indício do quanto

Os relatos sobre a destruição da exposição são evasivos e inconclusivos. Nada consta nos arquivos sobre a exposição no Centro de Pesquisa do MASP, nem nos jornais da época. Fato que pode ser explicado pelos efeitos do AI-5 e da censura sobre os veículos de imprensa. No catálogo O fim da arte segundo Nelson Leirner (1995), lançado por ocasião da exposição retrospectiva de Leirner no Paço das Artes, o curador Agnaldo Farias credita a destruição "a imprevisibilidade inerente ao projeto [...] o que poderia ser interpretado como fragilidade das mesmas ou, então, como violência de um público naturalmente distante das manifestações artísticas”. A menção ao envolvimento do Comando de Caça aos Comunistas parte do próprio artista quando entrevistado por ocasião da abertura da reencenação de Playgrounds em 2016, em: Folha de São Paulo: edição de 17 mar. 2016. Disponível online: https://www1.folha.uol.com.br/ilustrada/2016/03/1750659masp-inicia-onda-de-remakes-com-playgrounds-de-nelson-leirner. shtml?origin=folha .Acesso em em 8 dez. 2019.

"Uma noite, o pessoal do Comando de Caça aos Comunistas 
a contestação de Leirner extravasava o sistema artístico e provocava as estratégias repressivas agravadas pelo recrudescimento da ditadura civil-militar desde o decreto do AI-5, meses antes. A esse respeito, o artista afirma retoricamente: “Meus trabalhos interativos, que são toda uma série dos anos 1960, estão guardados por soldados” (LEIRNER, 2011, depoimento vídeo Assim É, se Lhe Parece ${ }^{202}$ ).

A importância dessa exposição, um tanto ausente da historiografia ${ }^{203}$, pode ser compreendida por múltiplos pontos de vista. Um primeiro diz respeito à própria importância da inauguração do Museu e sua primeira experiência com as potencialidades geradas pelo Vão Livre como espaço de engajamento direto e interlocução com um público espontâneo e não "especializado”. Outro aspecto é a construção de uma narrativa que adensa aquela demasiadamente tributária dos desdobramentos do neoconcretismo, representado por Lygia Clark e Hélio Oiticica ${ }^{204}$, como fundamental vertente de ensaios de interação e participação na arte brasileira. Afinal, Exposiçãonão-exposição e seu desfecho drástico propunham uma ruptura direcionada ao sistema de arte e seu controle sobre

destruiu metade das obras, lembra Leirner. Não daria tempo para fazer outras peças e tudo ficou jogado no chão, arrebentado até o fim”. Disponível em:https://m.folha.uol.com.br/tv/ ilustrada/2016/03/1751133-masp-inicia-onda-de-remakes-complaygrounds-de-nelson-leirner.shtml. Acesso em: 29 nov. 2019.

202 Filme documentário dirigido por Carla Gallo, onde a frase citada de Leirner nomeia um “capítulo” do documentário (18:0321:47min), no qual o artista comenta seu desencanto com o que entende ser um esvaziamento de seus trabalhos, uma vez que adquiriram valor comercial e são exibidos como pura visualidade, destituídos da interatividade para a qual foram criados.

203 Pouco se encontra sobre a exposição, mesmo no acervo do Centro de Pesquisas do MASP, e sua história se fia em relatos. Nos acervos de jornais, a destruição da exposição pelo Comando de Caça aos Comunistas simplesmente não foi noticiada, o que se explica pelo período de tensão e censura agravado pelo AI-5 em vigor desde dezembro de 1968. A exposição e sua destruição ressurgem como fato apenas nas matérias sobre sua reencenação em 2016.

204 Nesse sentido, Agnaldo Farias comenta em texto, no catálogo da exposição individual de Nelson Leirner Por que Museu? (2005-2006), no MAC de Niteroi: “o artista não só passou a existir como se tornou ponto de referência alternativo à decantada vertente construtiva que desembocou no Neoconcretismo - Lygia Clark e Helio Oiticica à frente -, trilha que nos últimos anos passou como sendo a única, sobretudo para os estrangeiros, ávidos em confirmar sua suposição de que no Brasil a sensualidade faz margem com uma arte de matriz interativa, a quem toda nossa arte contemporânea rende tributo” (FARIAS, 2005, p. 21). 
a fruição sacralizada e distanciada do público, ampliando o debate para o próprio enquadramento do formato exposição, atacando de maneira literal e disruptiva os protocolos do espaço expositivo.

A originalidade dos experimentos de Leirner é concomitante a outros casos exemplares no cenário internacional, isso quando não antecipa questões sensíveis para a arte desse período. Playgrounds se inscreve, portanto, num conjunto de exposições evocadas quando o assunto é interação e participação, tendo o jogo como experiência crítica e transformadora, na medida em que provoca elaborações políticas de alta densidade, encontrando correspondência em trabalhos como The Model for a qualitative society <imagem C3.12 p.215>, que Palle Nilsen realiza durante três semanas no Moderna Museet de Estocolmo, em 1986, ou mesmo Bodyspacemotionthings, de Robert Morris <imagem C3.13 p.216>, que só aconteceria em 1971, na Tate Gallery, em Londres.

Nesse sentido, o trabalho de Nilsen e a radicalidade com que enfrenta a construção da autonomia na educação infantil, colocando o museu no centro dessa discussão como agente de processos de aprendizagem, reverbera na crescente influência dos programas de mediação nos espaços de arte, e faz dele uma referência extremamente atual, tanto para reencenação de Playgrounds, em 2016, no MASP ${ }^{205}$, como de Playgrounds, reinventar la plaza (2014), no Museu Reina Sofia, em Madri, e mesmo para outras exposições que proliferaram nesse período com o mesmo tema ${ }^{206}$.

Em todas elas, há uma característica comum: a retomada de um conjunto de propostas de artistas e arquitetos que produziram peças esculturais e abertas à apropriação imaginativa. São revisitados playgrounds

A reencenação de Playgrounds, em 2016, como exposição coletiva, fazia parte do programa de reorganização do MASP após anos de uma gestão desastrosa que o descaracterizou como instituição. Retomar o momento de inauguração do edifício e as exposições que aconteceram então significava um olhar do museu para sua história e seu rico repertório de referências, que descarta a necessidade de um mero espelhamento em modelos importados (PEDROSA, 2016, p. 5).

206 Alguns exemplos são The Playground Project (2013), no museu Carnegie Museum of Art, em Pittsburg, Art Experiment, The Playground Project: from New York to Moscow (2016-2017), no Garage Museum of Contemporary Art de Nova Iorque, Los parques de Nogushi (2016-2017), no Museu Tamayo, no Mexico, ou The Playground Project (2016), no Kunsthalle Zürich. 
pensados por artistas como Isamu Nogushi ou Waldemar Cordeiro ${ }^{207}$ e a maneira como fundiam paisagem e brinquedos voltados para a ocupação de parques e praças. São também recorrentes as referências ao arquiteto Aldo Van Eyck e a maneira como direcionou a ocupação de terrenos vazios na Amsterdam do pós-guerra. Esses terrenos eram preenchidos com equipamentos infantis simples e criavam praças que modulavam gradualmente o trânsito entre espaços públicos e os lugares desenhados para se adequarem à escala dos bairros como estratégia de resistência ao avanço de propostas funcionalistas e tecnocráticas <imagem C3.14 p. $217>$.

Van Eyck integrou o Team 10, grupo que se forma e dá início a uma revisão crítica desde o interior dos $\mathrm{CIAMs}^{208}$, pondo em questão a Carta de Atenas (1933) e sua visão segmentada da vida cotidiana, cuja perspectiva desconsiderava a preexistência dos centros históricos e a participação do indivíduo real na vida cotidiana em oposição ao ideal de homem moderno.

O que constitui uma crítica de matriz semelhante à empreendida pelos Situacionistas ${ }^{209}$, cujas ideias e práticas propunham novas formas de sociabilidade embasadas pela noção de jogo - implícito às práticas efêmeras de deriva, que propõem um caminhar errante para se perder e surpreender "apaixonadamente" com a arquitetura e os espaços da cidade, ou a construção de situações, ambiências vivenciadas motivada pelo desejo e partilhadas num domínio coletivo. Esse seria o antídoto a agir contra a alienação e espetacularização da vida nas cidades a partir da

O playground do Clube Espéria (1963), de Waldemar Cordeiro artista múltiplo que atuava também como paisagista, designer e crítico - encontra-se, hoje, descaracterizado. O desenho original foi prejudicado pela cessão de parte do terreno que ligava o clube ao rio para a passagem da Avenida Marginal Tietê em 1970 e o restante passou a dividir espaço com brinquedos industrializados de plástico colorido - ver documentação recente em artigo publicado na revista Paisagem e Ambiente $n^{\circ} 42$ da FAU-USP (CARMONA-RIBEIRO; OLIVEIRA, 2018, p. 50). O labirinto em dupla espiral que ocupava o centro do parque infantil foi remontado e apresentado na 30 Bienal de São Paulo em 2012.

208 Conforme tratado no $1^{\circ}$ capítulo, em especial na nota $n^{\circ} 40, \mathrm{p} .37$.

209 “Mais do que simplesmente coincidências ou questão de zeitgeist, existiram de fato contatos e trocas entre os dois grupos, principalmente através de seus membros holandeses e ingleses. [...] Aldo Van Eyck é o caso mais explícito desse intercâmbio" (JACQUES, 2003, p.27). 
conversão de seus habitantes em participadores ativos, ou "vivenciadores" de um jogo revolucionário.

O Urbanismo Unitário (U.U.), elaborado pela I.S. (Internacional Situacionista) e que tem em Guy Debord seu principal expoente, propõe "meios de ação que convergem para uma composição integral do ambiente" (DEBORD, 1957, p.54). Partindo de um diálogo inicial com a arte, particularmente os desdobramentos das vanguardas dos anos XX - o Dadá e o Surrealismo mais precisamente -, a diluição das fronteiras entre arte e vida passa a ser compreendida pela I.S como indissociável da arquitetura e da vida urbana dada sua influência determinante na vida pública e, portanto, a esfera política.

“A arte integral, de que tanto se falou, só se poderá realizar no âmbito do urbanismo. Mas já não corresponderá a nenhuma das tradicionais definições de estética”. (DEBORD, 1957, p. 55)

O tempo do viver afirmado em um espaço urbano lúdico, livre para ser modificado, agiria, assim, contra o tempo utilitário ordenado pela distribuição espacial baseada na produtividade racional e funcional moderna - condição que é evidente na forma como o Vão Livre projetado por Lina Bo Bardi se apresenta, segundo Van Eyck (apud FERRAZ, 2015, p. 50), como um fenômeno ou "um choque no primeiro encontro, contrário a tudo aquilo que fomos acostumados equivocadamente”, ou surpreenda John Cage, que reconhece ali uma 'arquitetura da liberdade’. Como relata a própria arquiteta:

Acostumada aos elogios pelo 'maior vão livre do mundo, com carga permanente, coberto em plano', achei que o julgamento do grande artista talvez estivesse conseguindo comunicar aquilo que queria dizer quando projetei o MASP: o museu era um 'nada', uma procura da liberdade, a eliminação de obstáculos, a capacidade de ser livre perante as coisas. (BARDI, L., 2009, p. 166)

Essa capacidade de ser livre perante as coisas é garantida pelo grau de indeterminação que transforma esse espaço em ambiente da prática do social, estabelecendo-se como uma fissura que resiste a qualquer controle de comportamento do público, sendo revivificado por usos jamais determinados, 
ainda que alguns tenham sido imaginados e ensaiados nos desenhos em que vemos circos, brinquedos e esculturas. Nesse sentido, não seria exagero aproximá-lo do que Rancière elabora como "eficácia da desconexão":

[...] que põe à mostra que a eficácia da arte não consiste em transmitir mensagens, modelos ou contramodelos de comportamento ou ensinar a decifrar representações. Ela consiste sobretudo em disposições dos corpos, em recorte de espaços e tempo singulares que definem maneiras de ser, juntos ou separados, na frente ou no meio, dentro ou fora, perto ou longe. [...] Pois o que ela opõe às duvidosas lições de moral da representação é simplesmente a arte sem representação, a arte que não separa a cena da performance artística da vida coletiva. (RANCIÈRE, 2019, p. 55)

Por essa lógica, o vão passaria de antessala do museu a ponto nevrálgico de sua estrutura pelo potencial de fazer convergir a performance artística e a vida coletiva. Um espaço atravessado pelo ordinário e o espontâneo, por onde circulam informações e discussões políticas que o MASP assiste cotidianamente, mas não consegue abarcar em toda sua potência.

\section{Playgrounds (2016)}

Esse ambiente, desencadeador de relações e dissensos, foi intensamente documentado pela curadora Luiza Proença ${ }^{210}$, então responsável pelo programa de Mediação e Programas Públicos do museu, e que, durante o período de pesquisa e projeto da reencenação de Playgrounds (2016) - exposição

210 De uma conversa com Luiza Proença em 25 de nov. 2019, na qual externou sua inquietação com a turbulência das manifestações políticas que desde 2013 têm no Vão Livre seu ponto de encontro e concentração. Manifestações intensificadas com a aceitação do processo de impeachment da presidente Dilma Roussef pela Câmara dos Deputados, em dezembro de 2015, até seu afastamento em agosto de 2016, período que coincide com a pesquisa, montagem e inauguração de Playgrounds 2016. 
que divide a curadoria com Adriano Pedrosa e Julieta González -, reviveu uma época de agitação política, com ares de intolerância e autoritarismo, que remetiam a 1969.

Diante desse cenário, a dimensão pedagógica de uma exposição como Playgrounds poderia atualizar questões presentes desde a fundação do museu, e que aproximam o antimuseu dos Bardi da antiescola de Paulo Freire como uma base experimental para a produção de uma crítica acerca dessas instituições e sua vocação pedagógica para reverter processos de massificação em favor de uma democratização do ensino e da cultura, tendo a arte como elemento central para essa reconfiguração, como expõe Olivia Oliveira no texto Os antimuseus e antiescolas de Lina Bo Bardi e Paulo Freire (2015).

Segundo Oliveira, os métodos expositivos e didáticos dos museus de Lina Bo Bardi e os métodos revolucionários de alfabetização propostos pelo educador Paulo Freire baseiamse numa pedagogia de emancipação e na liberdade exercida como diálogo horizontal, nos quais palavras e quadros são estímulo para o debate consciente e crítico em face do que se analisa, numa relação que reconhece no ouvinte e no visitante o poder de criação e transformação do mundo (OLIVEIRA, 2015).

Revisitar Playgrounds significava para a curadoria, particularmente para a equipe de Mediação e Programas Públicos, exercer uma escuta que pudesse estabelecer reconexões com o Vão Livre como espaço ativo do museu, com toda a potência que sua utilização pode representar na construção de processos voltados a uma troca franca entre o repertório cultural que o MASP armazena e disponibiliza, e a absorção das experiências que vêm de fora - uma questão central para a elaboração de ações educativas menos instrumentalizadas e mais independentes de instâncias prescritivas de mediação.

Daí a mobilização de um “instinto de jogo” como proposta de mediação direta capaz de provocar experiências emancipatórias com dimensão pública amplificada ${ }^{211}$. Esse

A reflexão de Olivia Oliveira sobre os antimuseus de Lina Bo Bardi e as antiescolas de Paulo Freire baseia-se numa conjuntura análoga à que Jacques Rancière apresenta em O espectador emancipado (2012). Partindo de seu texto $O$ mestre ignorante (2004), no qual pensa a importância da educação como processo horizontal de construção crítica para do conhecimento, Rancière aproxima o ensino e a arte como instâncias 
"instinto de jogo", que segundo Rancière é matéria central para superar o paradoxo do espectador, é explicitado no teatro pela oposição entre Brecth e Artaud. "Para um o espectador deve ganhar distância; para outro, deve perder qualquer distância” (RANCIÈRE, 2019, p. 10).

A superação desse paradoxo não implica apenas numa superação da oposição entre "ignorância e saber, atividade e passividade, individualidade e comunidade" (RANCIÈRE, 2019, p. 22), mas uma resistência à sujeição do domínio do espetáculo sobre a cultura e a vida, conforme enunciado por Guy Debord. Rancière evidencia que essa ruptura não é um ato reducionista que contrapõe o olhar e o agir, afinal "o espectador também age[...]. Ele seleciona, compara e interpreta [...].Assim, são ao mesmo tempo espectadores distantes e intérpretes ativos do espetáculo que lhes é proposto" (RANCIÈRE, 2019, p. 17).

Dessa maneira, o "instinto de jogo" é o que ocasiona, para Rancière, a suspenção de uma hierarquia social do regime estético que "se definia pela imposição ativa de uma forma à matéria passiva, e esse efeito coadunava com uma hierarquia social na qual os homens de inteligência ativa dominavam os homens da passividade material" (RANCIÈRE, 2019, p. 58), configurando uma "eficácia estética" por meio da produção de um dissenso - uma operação capaz de reconfigurar a experiência do comum e do sensível.

Seria com esse intuito que as peças instaladas no Vão Livre, entre a escultura e o brinquedo, entre a contemplação e o uso, disponíveis gratuitamente e diretamente conectadas com a rua apresentariam uma oportunidade de reexaminar as atividades de mediação do museu por meio de dispositivos que desencadeassem novas relações com o público, o que é explicitado pelo texto de Luiza Proença para o catálogo da exposição:

Como o museu, enquanto instituição e escola, pode também aprender com esses processos em seu entorno e entender seus públicos como sujeitos que afetam e são afetados, e que são capazes de subverter o estado das coisas? Quais

culturais determinantes para a emancipação intelectual, estendendo esse questionamento para o papel do "espectador no cerne da discussão sobre as relações entre arte e política” (RANCIÈRE, 2019, p. 8). 
níveis ou esferas de mediação o museu pode estabelecer nesse contexto? Talvez devêssemos falar de um revezamento de agentes mediadores, entre instituição, obras e seus públicos, que, como num jogo, assumem tanto as funções de participantes como de propositores, de orientandos e orientadores, de conduzidos e condutores. Parece ser por essa via de troca e aprendizado mútuo, pela criação de situações e não de programas, que um museu popular ou do povo seja possível. (PROENÇA, 2016, p. 19)

O que ocorre, no entanto, é uma tímida ocupação do Vão Livre por Playgrounds (2016), fato explicado como consequência da complexa negociação sobre o uso deste espaço submetido à agenda da prefeitura municipal, que dentre seus compromissos acolhe a tradicional Feira de Antiguidades aos domingos, sob a sombra do bloco suspenso.

Apenas dois trabalhos, entre os seis que integravam a exposição ${ }^{212}$, puderam estar acessíveis em condições semelhantes aos trabalhos de Leirner na primeira edição da exposição em 1969: Zero ao infinito [Zero to Infinity] (19682016), do artista Rasheed Araeen <imagem C3.16 p.219>, por ser facilmente manipulável, permitindo seu deslocamento aos domingos ou recolhimento à noite; e Peça de conversa (2016) <imagem C3.17 p.220 >, de Celine Condorelli, uma espécie de gira-gira colorido insinuado por Lina Bo Bardi no desenho Estudo preliminar - Esculturas praticáveis do Belvedere <imagem C 3.9 p.212 >. Por não interferirem nas atividades programadas pela prefeitura, ambos puderam permanecer acessíveis ao público que passava pelo Belvedere.

Peça de conversa partiu da reinterpretação do mesmo desenho que informou o Carrossel, de Carlos Blanc e Maria Helena Chaturi, realizado no começo da década de 1970. Uma releitura que foi desdobrada em dois módulos, um ocupando o ponto no Belvedere, sugerido pelo desenho de Bo Bardi, enquanto o outro foi posicionado no subsolo imediatamente

Além de Conversation Piece (2016), de Celine Condoreli, e Zero to Infinity (1968-2016), de Rasheed Araeen, a exposição reuniu os seguintes trabalhos: Enquanto Caminhamos... sonhamos (...), (2016), de Ernesto Neto, Condutores (2016), O Grupo Inteiro, Lyautey Unit Soft Blocks (Playgorund in a Box) (2015) de Yto Barrada, Espaço-dispositivo para conversar sobre a escola que queremos: se a escola se repensa, $o$ que acontece com os outros espaços? (2016), do Grupo Contrafilé. 
abaixo do primeiro, como se ambos girassem em torno de um mesmo eixo.

Condorelli qualifica esse trabalho como mais uma etapa de sua pesquisa sobre "estruturas suporte", o que, em suas palavras, significa uma interpretação do "objeto como dispositivo".

Segundo a artista-arquiteta,

O encontro com um conjunto de ideias ou um objeto acontece através de algo que muitas vezes é um dispositivo físico [...]. Um encontro entre arte e arquitetura de alguma maneira, sem separações disciplinares. Estou interessada no enquadramento, na estrutura subjacente da forma que as coisas aparentam para nós, que frequentemente faz parte de algo que desconsideramos. As coisas no mundo chegam para nós mediadas por outras coisas, por ações que muitas vezes permanecem invisíveis porque não estamos treinados para enxergá-las. (CONDORELLI; PEDROSA, 2016, p. 44)

Ao utilizar o conceito de dispositivo, para pensá-lo como objeto num campo híbrido entre arte e da arquitetura, Condorelli propõe uma articulação de relações entre seres humanos e coisas, entre problemas e ideias, conferindo papel central à espacialização de objetos e aos conceitos que suscitam no ambiente expositivo - o que pode ser oportunamente relacionado com a noção de enunciado espacial $^{213}$ como camada infraestrutural das exibições. E, para isso, ao utilizar do conceito de dispositivo, remete-se diretamente à Michel Foucault e à importância estratégica desse termo no pensamento do filósofo sobre governamentalidade.

Em O que é um dispotitivo (2005) ${ }^{214}$, o filósofo italiano Giorgio Agamben procura sistematizar a genealogia do

214 O que é um dispotitivo (2005) é um texto que deriva de versão apresentada por Giorgio Agambem como conferência em 2005, no Brasil. Nele, propõe uma chave de leitura para o termo dispositivo na obra de Michel Foucault, com papel fundamental para a compreensão de mecanismos políticos contemporâneos, publicado no livro O que é o Contemporâneo? e outros ensaios (2009). 
termo dispositivo e a maneira como é empregado por Foucault, inferindo que "parece remeter a um conjunto de práticas e mecanismos (ao mesmo tempo linguísticos e não-linguísticos, jurídicos, técnicos e militares) que têm o objetivo de fazer frente a uma urgência e de obter um efeito mais ou menos imediato" (AGAMBEN, 2015, p. 35). Por isso, segundo o autor, apresentando um caráter flutuante e estratégico, como uma rede que mantém e determina as relações de poder, um dispositivo pode abarcar "discursos, instituições, edifícios, leis, medidas de polícia, proposições filosóficas etc." (AGAMBEN, 2010, p. 29).

Assim, esses objetos-dispositivos, chamados de “estruturas suporte” por Condorelli, abarcam camadas que não se estratificam nos termos que a estrutura produtiva segmentada e setorizada que o museu, como modelo de instituição cultural, adquiriu para responder às demandas externas, tornando-se, ao longo do tempo, um espaço opaco, que maneja visibilidades e invisibilidades, e "um local da desencarnação gradual do público como requisito para a chamada apreciação da arte" (CONDORELLI; SEGADE, 2018, p. 30$).{ }^{215}$

Peça de conversa dialoga mais proximamente com o que Lina Bo Bardi chamaria de "esculturas praticáveis" ou também de "estruturas para brincar". Dispositivos que, assim como os cavaletes de concreto e vidro ${ }^{216}$ desenhados para a exibir o acervo, ou como A Grande Vaca Mecânica (1988) <imagem C3.15 p. 218>, que desenharia posteriormente para abrir uma exposição realizada no MASP, proporcionam conexões com os públicos, transferindo-lhes a possibilidade de criar relações e construir conhecimento. $\mathrm{Ou}$ seja, colocam-se de maneira aberta, "evitando a separação entre a elaboração da exposição e seu caráter educativo",

No original "You are describing a movement that goes from a cultural institution model of the museum as a place to go and [...], to it being the site of audiences' gradual disembodiment as a requirement for a so-called appreciation of art."

216 Os cavaletes de concreto e vidro são uma experiência única na maneira como rompem com a forma tradicional de exibição de quadros, sempre distanciados por faixas de segurança, organizados sequencialmente de maneira a induzir leituras predeterminadas por seu arranjo nas paredes e legendas explicativas. Os cavaletes possibilitam uma proximidade do visitante com a obra, e uma leitura em relação às outras obras e ao ambiente como um todo. As legendas são colocadas no verso, o que permite uma abordagem desprevenida do espectador, facultando um percurso livre entre o conjunto exposto. 
com influência direta sobre os programas de mediação. Condorelli aborda o assunto numa entrevista, na qual demostra sua admiração pelos projetos expositivos de Lina Bo Bardi e como identifica neles uma maneira de agir com a qual se alinha, "evitando a separação entre o fazer da exposição e a educação. Eu entendo os museus como lugares de construção coletiva" (CONDORELLI; SEGADE, 2018, p. 31).

Diante das questões levantadas por Proença, Playgrounds apresentava uma importante oportunidade de se repensar processos de mediação, a partir de uma pesquisa que revisitava os repertórios engendrados pelo MASP, em seu importante período de formação, enquanto, ao mesmo tempo, procurava construir novos repertórios e práticas coletivas de caráter público e em diálogo mais próximo com as ruas. Um desfaio que, segundo a curadora, foi melhor correspondido por um trabalho como os desdobramentos de Rebelião das crianças (2005-), do Grupo Contrafilé - projeto que o grupo vem realizando desde 2005 como uma plataforma para pensar o papel da criança e do jovem na construção do comum e da "vida urbana" 217 , e que foi pensado a partir do contexto da exposição e de uma compreensão da abrangência da brincadeira. Segundo o Grupo:

[...] em A Rebelião das Crianças estávamos tentando entrar em contato com esses lugares de afeto, tendo a criança como potência central. Quando entendemos que as ocupações nas escolas têm algo de brincadeira, no sentido de um possível que está ali sendo criado, de uma normalidade que está sendo desafiada, estamos entendendo que ali está o sentido vital da brincadeira, um estado que é de rebelião, que coincide com o próprio estado criança. (D'AMBROSIO; CONTRAFILÉ, 2017, online)

Sobre essa questão o Contrafilé elabora na entrevista concedida à Luiza Proença para o catálogo da exposição Playgrounds (2016), nas páginas 57-58: “No começo do processo do Grupo, entendíamos o espaço público como território da cidade, de pensamento sobre o espaço urbano, do ocupar e intervir nele. Ao entrar em uma dimensão mais micro e invisível dos processos, o espaço público foi deixando de ser apenas um espaço físico e de tornando presente também em territórios não físicos, como o corpo [...]. A cidade somos nós; não o asfalto, o prédio [...]. Vida urbana talvez seja o termo mais apropriado para o que estamos pensando". 
Dessa forma, para a exposição Playgrounds, o grupo propôs a realização de encontros concomitantes no MASP e nas escolas públicas paulistas, então ocupadas pelo Movimento Secundarista ${ }^{218}$. A relação entre estes espaços não é casual, uma vez que, como lembra Proença (2016, p. 17), “o primeiro protesto que reuniu um grupo de estudantes, em 6 de outubro de 2015, foi justamente o Vão Livre do MASP, onde ocorria, no mesmo momento, o seminário Histórias da Infância”.

Ao longo dos seis encontros realizados no MASP, reuniram-se estudantes, artistas, pesquisadores e comunidade de maneira horizontal. O lugar escolhido foi uma esquina do mezanino, no subsolo do museu, configurando o que o Grupo Contrafilé chamou de Espaço-dispositivo para conversar sobre a escola que queremos: se a escola se repensa, o que acontece com os outros espaços? (2016).

Neste canto, escolhido por sua luminosidade, foram dispostas peças de mobiliário: banquetas em torno de um tapete circular verde para as rodas de conversa - elemento essencial replicado como "clareira" nas escolas; caixotes de madeira para a divisão de ambientes, também funcionando como biblioteca; cadeiras para encontros em torno da mesa-lousa; vasos de plantas; e imagens impressas fixadas diretamente sobre o vidro. Uma ambientação de caráter doméstico que produzia um estranhamento em relação ao espaço de exibição, dada a maneira como foram transpostos para o museu objetos do universo cotidiano.

O Grupo Contrafilé enunciava, desse o modo, a inversão que pretendia empreender ali, assinalando que não se tratava da exibição de algo, mas da demarcação de um espaço a ser ocupado pela presença física dos integrantes do grupo e seus diversos interlocutores. Gesto que corroboraram ao deitar a lousa, sublinhando a importância da horizontalidade na construção do conhecimento, e ao sugerir a alteraração de seu

O movimento de ocupação das escolas estaduais de segundo grau em São Paulo, iniciado no final de 2015, se estendeu ao longo de 2016 e mobilizou a opinião pública mediante a ocupação de mais de 200 escolas e a realização de protestos de rua contra o programa de "reorganização do ensino” do governo de São Paulo que, de maneira arbitrária, pretendia fechar 92 escolas e transferir mais de 300mil alunos. A articulação dos estudantes nas escolas ocupadas fortaleceu a participação da comunidade, aproximando as famílias e os movimentos sociais que passaram apoiar o movimento na reinvenção dos espaços escolares propondo novos usos que foram geridos coletivamente, e criando uma programação alternativa que atraiu artistas, professores, intelectuais e sociedade como um todo em torno do debate sobre os rumos da educação pública. 
status de artistas para se autodenominarem "espectadores públicos" ${ }^{219}$, ou seja, participantes das atividades, revezandose no papel de autores e espectadores.

Como resultado, o trabalho se desenvolve também como uma publicação de autoria partilhada com os Secundaristas de Luta e com uma rede que envolveu mais de setenta pessoas. Distribuído gratuitamente, A Batalha do Vivo (2016) ${ }^{220}$ reúne textos, imagens, desenhos e relatos que apresentam a potência do Movimento Secundarista em seu impulso de construção coletiva como desígnio de outras perspectivas de comum, que a partir das escolas poderia se estender aos museus e à cidade.

Um grupo como o Contrafilé, que é conhecido por sua atuação próxima do ativismo político ${ }^{221}$, é favorecido por situações como essa, na qual se infiltram na lógica expositiva para criar, através de processos educativos e de mediação, espaços nos quais os relacionamentos e as presenças desafiem os parâmetros que hoje regem uma forma de pensar e de fazer exposições. Um modo de agir que pode ser associado a um "hackeamento" 222 da estrutura institucional, tal como sugere o crítico Stephen Wright em Para um léxico de usos (2016), trabalhando nas “fendas” das redes de produção para realizar a "liberação do conhecimento de uma economia da escassez" (WRIGHT 2016, p. 93). Nesse sentido, a exposição Playgrounds proporcionou um contexto para que o grupo alargasse a investigação proposta e incluísse novos atores e participantes na produção e distribuição de informação a partir do museu.

219 Termo utilizado pelo grupo para definir sua atuação no MASP, na entrevista concedida à Luiza Proença e que integra o catálogo da exposição.

220 Disponível em: https://issuu.com/grupocontrafile/ docs/a_batalha_do_vivo/182. Acesso em 7 jan. 2020.

221 Joana Zatz Mussi, integrante do Grupo Contrafilé, defende em sua tese de doutorado Arte em Fuga (2017) a confluência de uma produção artística de viés político e insurgências que, em seu fazer político, possuem uma dimensão estética indissociável de sua prática. Neste enclave ela discorre de forma a localizar a produção do Grupo Contrafilé.

222 Segundo o Stephen Wright "hacking” é uma palavra saxã que designa um corte chanfrado, ou talho obliquo feito por um machado. Termo que ganha novas conotações e usos a partir de sua absorção pelo universo da programação, principalmente a partir do manifesto do escritor McKenzie Wark A Hacker Manifesto (2004), no qual o autor trata o hackeamento como "uma prática relacionada à arte porque o sistema de produção de valor no mundo da arte dominante também tem como premissa um regime de escassez, sustentado pela assinatura do autor" (WRIGHT, 2016, p. 95). 
Essa ação de “hackeamento" não é uma condição nova no campo artístico, mas uma reinterpretação dos modos de operar diante do aparato da arte contemporânea que, impulsionado por novos agentes em escala global, passa a lidar com interesses econômicos, de mercado, e novos estatutos culturais cuja lógica é subvencionada por um modelo pautado na realização de exposições, distanciando-se de um enfoque sobre a obra ou a coleção.

Tendo isso em vista, operar de modo a intervir na lógica de produção das exposições significa reconhecer uma quantidade de investigações elaboradas por artistas que, a partir dos anos 1960, passam a tensionar as condições espaciais das galerias, os meios de produção e percepção das obras, e o modo como uma rede discursiva sustenta e impulsiona a arte. Uma variedade de proposições que, ao se apropriarem da exposição como objeto de produção, problematizam e questionam seus modelos e parâmetros estruturais.

Refiro-me aqui, dentre tantos outros exemplos ${ }^{223}$, aos trabalhos de Marcel Broodthaers e seu Musée d'Art Moderne, Département des Aigles, Section Publicitè (1972), exibido na Documenta 5, reunindo um reportório da cultura popular, tendo como tema a águia e sua mítica simbólica, associada à sagacidade e ao poder, para criar um museu ficcional com o propósito de desconstruir o sistema classificatório e arbitrário sobre qual se fundamentam. Outro exemplo são as performances de Andrea Fraser, em que a artista intervém justamente no intervalo entre a produção do discurso institucional e sua recepção por parte do público, assumindo o papel de guia do Museu de Arte da Filadélfia em Museum Highlights: A Gallery Talk (1989), ou em Little Frank and His Carp (2001), no qual suas reações são irônica e sensualmente encenadas de acordo com as instruções do áudio-guia do Museu Guggenheim Bilbao, projeto de Frank Gehry, exaltado pelas curvas sensuais de sua arquitetura.

Portanto, pensar o museu e seu papel educativo, a partir de uma exposição como Playgrounds, tendo o MASP como

Seria possível pensar aqui em grande parte de uma produção artística que se desdobra, a partir do último quarto do sec. XX, em instalações e performances que atacam diretamente a esfera institucional tanto pela suposta neutralidade física do cubo branco quanto por suas camadas discursivas a exemplo Hans Haacke, Michael Asher, Brian O’Doherty, Group Material, Antoni Muntadas, entre outros. 
ferramenta e meio dessa investigação, significa também explicitar os impasses que o debate em torno da participação, neste contexto específico, é capaz de desenredar.

É pertinente retomar aqui um comentário um tanto desiludido de Nelson Leirner, no qual ele relaciona a primeira edição de 1969 com a segunda edição da exposição Playgrounds em 2016:

Naquela época, a arte era um subterfúgio. Você dava mensagens de maneira subliminar. Hoje, acho que caberia ser mais direto, mais panfletário, menos sonhador. Vejo a arte agora como um tabuleiro de xadrez em que todas as peças são iguais. Quando os lados são da mesma cor, não existe jogo. (LEIRNER; MARTÍ, 2016, online)

Leirner decreta a impossibilidade do jogo, isto é, evidencia o dilema da arte entre a "superidentificação redutora com o outro" e a "desidentificação assassina do outro", nos termos colocados por Hal Foster, em O retorno do real (2007, p. 186). Em outras palavras, entre uma redenção na qual se internaliza e se domina a subjetividade da arte sob uma promessa libertária, e uma participação intersubjetiva na qual se constitui uma experiência efetiva do sujeito autônomo.

Ao identificar uma "virada etnográfica na arte contemporânea”, diante do "esgotamento das definições restritivas de arte e artista” e a crescente absorção da pauta multicultural, Foster associa esse momento à constituição de um "campo ampliado da cultura, que supostamente é o domínio da antropologia” (FOSTER, 2017, p. 174), ao mesmo tempo que clarifica as contradições implícitas na assimilação de tensões por parte do aparato da arte sob risco da neutralização de sua potência política.

Se os novos estatutos do público e as promessas de emancipação pela participação contêm doses de autoengano, à medida em que representam, numa lógica institucional, cifras e público que fazem girar a engrenagem da produção cultural, um espaço como o Vão Livre ainda representa uma bem-vinda indeterminação, um espaço liso $^{224}$ onde tudo pode acontecer,

224 Refiro-me aqui ao espaço liso conforme a conceituação de Delleuze e Guatarri, como o espaço “onde se desenvolve a máquina de guerra”, ou seja, como espaço nômade, de múltiplas identidades móveis cuja 
mas nada parece aderir. Um espaço que se consolida pela importância de seu “'funcionalismo invertido', com o uso sendo definido pelo usuário e não pelo conhecedor específico" (PERROTA-BOSCH, 2013, online).

É justamente diante dessas condições e contradições que Playgrounds 2016 oscila, e é nessa circunstância pendular que instâncias de mediação conquistam proeminência e passam a constituir um significativo eixo investigativo para a arte, a arquitetura e sua propensão para criar condições de investigações compartilhadas.

assimilação é fugidia e que, juntamente com seu duplo indissociável, o espaço estriado e sua regulação fixada e "instituída pelo aparelho de Estado" alternam-se como "dois espaços que existem de fato graças às misturas entre si: o espaço liso não para de ser traduzido, transvertido num espaço estriado; o espaço estriado é constantemente revertido, devolvido a um espaço liso"(DELEUZE;GUATTARI, 1997, p. 179-180). 



\section{Coleção de referências}




\section{C3.1 A marquise ocupada (2014) Eduardo Gurian}

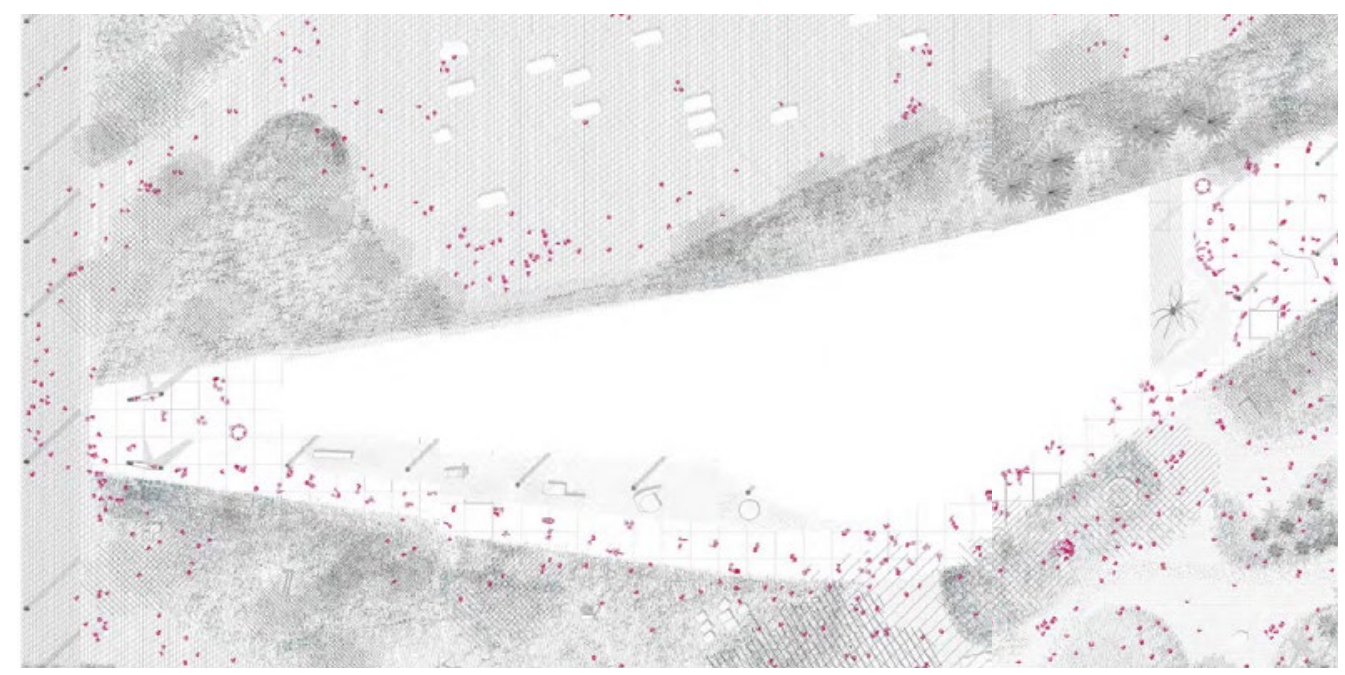

É através da repetição de tipos gráficos transferiveis, que reproduzem objetos e pessoas em situações cotidianas, que Gurian ocupa livremente o desenho - uma planta onde vemos a projeção da cobertura sobre o piso da Marquise diluindo-se no parque. Esse desenho demonstra que o espaço se conforma numa resultante dos acontecimentos sob a cobertura, como um campo determinado pelos corpos que ali estão, tanto quanto por pilares e vegetação.

Ao registrar os usos e sua distribuição pela Marquise, Gurian coteja seu desenho com textos. Dentre eles, Condições de Campo (1999), de Stan Allen, oferece embasamento teórico para destacar que a dinâmica dos corpos e suas regras intrínsecas são o que configuram a Marquise como elemento infraestrutural capaz de "unificar diversos elementos, ao mesmo tempo respeitando a identidade de cada um deles" (ALLEN, 2013, p.103). Ou seja, não há uma tipologia que predetermine a forma das coisas, nem uma construção que organiza um todo, mas um espaço que se constitui entre as coisas.

Esse "entre" as coisas, trabalhado como matéria pelo minimalismo norte-americano
- implicado na ampliação do campo da escultura para o todo espacial de seu entorno a partir da inserção do objeto -, é expandido pelas especulações de artistas como Barry Le Va, cujas Esculturas Distribucionais, do final dos anos 1960, resultavam de ações aleatórias sobre os materiais no espaço expositivo, sendo posteriormente registradas como diagramas dessas ações.

É dessa forma que o registro de Gurian nos apresenta os usos da Marquise: como um diagrama informado pela aleatoriedade do usuário indisciplinado, onde os eventos e ações cotidianas se desvinculam de qualquer programa. A escolha dos locais para o posicionamento de ambulantes incide nos pontos de maior fluxo, variando de acordo com os ritmos e públicos que transitam entre a área coberta e o parque. Skatistas e patinadores buscam impulso nos declives, ainda que mínimos, utilizando dos pilares tanto como obstáculos quanto para o apoio das mochilas. Os pilares em " $\mathrm{V}$ ", nas extremidades que tocam o pavilhão da Bienal, ou o Museu Afro-Brasil, são utilizados como espreguiçadeiras que acomodam o corpo em posição ideal para o descanso. 


\section{C3.2 Cassino da Pampulha (1944) \\ Marcel Gautherot \\ Still do vídeo Museu de Arte da Pampulha (2013) \\ Yuri Firmeza e Amanda Melo da Mota}
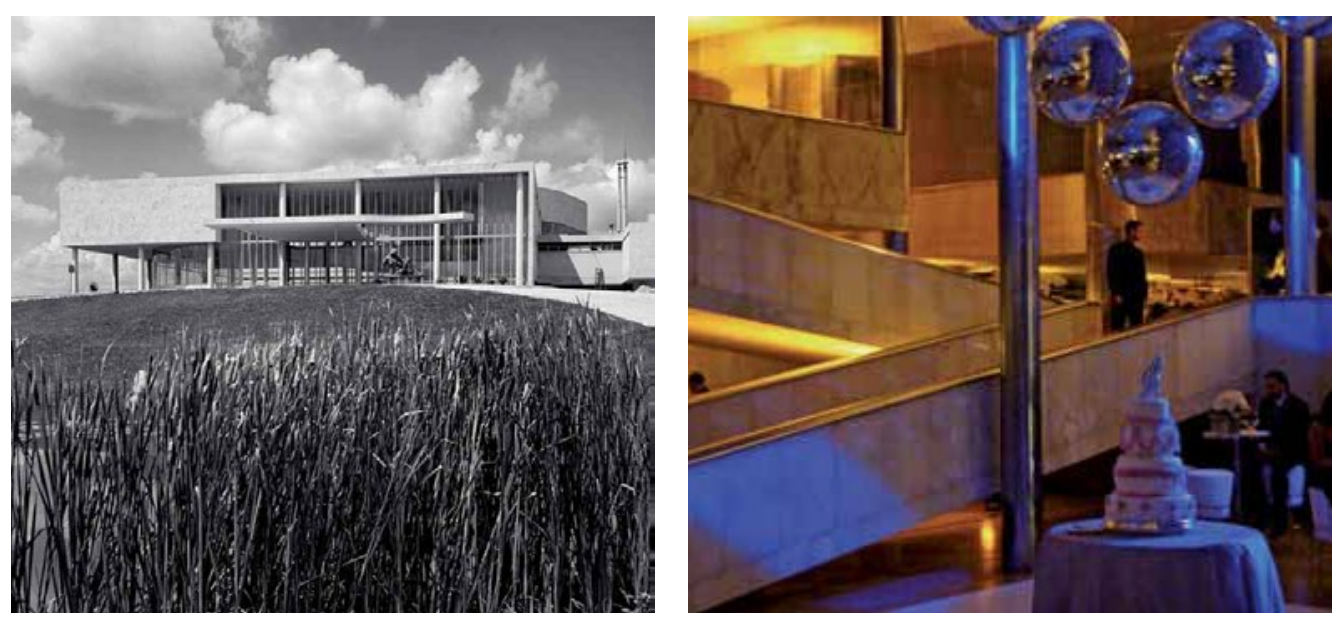

O Cassino da Pampulha faz parte de um conjunto de quatro edifícios, construídos entre 1940 e 1942, em torno da lagoa de mesmo nome. Destinada a se tornar uma grande área de lazer em Belo Horizonte, com projetos encomendados a Oscar Niemeyer por Jucelino Kubitschek, quando este era prefeito de Belo Horizonte, o conjunto, segundo Mario Pedrosa, em um texto da época para a revista Architecture D'aujourd'hui, "tratava-se de um capricho [...], mas não se tratava de uma manifestação arcaica contraditória [...]; pois era uma manifestação típica do estado e das aspirações da sociedade brasileira de meados do séc. XX" (PEDROSA apud BRUAND, 1991, p.109).

O cassino, um dos edifícios emblemáticos que contribuíram para a divulgação da arquitetura moderna brasileira no exterior, transforma-se no Museu de Arte da Pampulha (MAP) em 1957, onze anos após a proibição do jogo no Brasil. E assim como outros museus brasileiros, o MAP teve que se adaptar às instalações preexistentes.

Hoje, com escassos recursos, ele mantém importantes programas de arte contemporânea no cenário nacional, como o projeto Arte Contemporânea no MAP, voltado à produção de projetos site-specific, e o programa de residências artísticas Bolsa Pampulha.
Contemplados com a bolsa em 2008, Yuri Firmeza e Amanda Melo da Mota identificaram as transformações que o museu experimentava periodicamente para adequar sua agenda de exposições aos eventos privados - uma forma de captar recursos. Infiltrados em um desses eventos, confundem-se com os convidados e se fazem passar por uma equipe de filmagem registrando a festa de casamento que ali acontecia.

$O$ resultado é um desconcertante contraste entre a banalidade das cenas do casamento e a aura imponente do edifício - quando captada por Marcel Gautherot, em 1944. Um curto-circuito de usos: "de cassino-museu a museu-salão de festas, esta passagem evidencia o destino melancólico de uma modernidade que não consegue manter a linha pura de suas formas" (LAGNADO; MAIA, 2013, p.162).

Integrando a mesma exposição, as imagens explicitam nossa contradição atávica derivada da dissolução histórica do público e do privado, e contribuem para um entendimento das relações ambivalentes e dos diversos níveis de negociação envolvidos na realização de programas que estimulem a produção de arte no âmbito nacional. 


\section{C3.3 Catarata (2013) Federico Herrero}

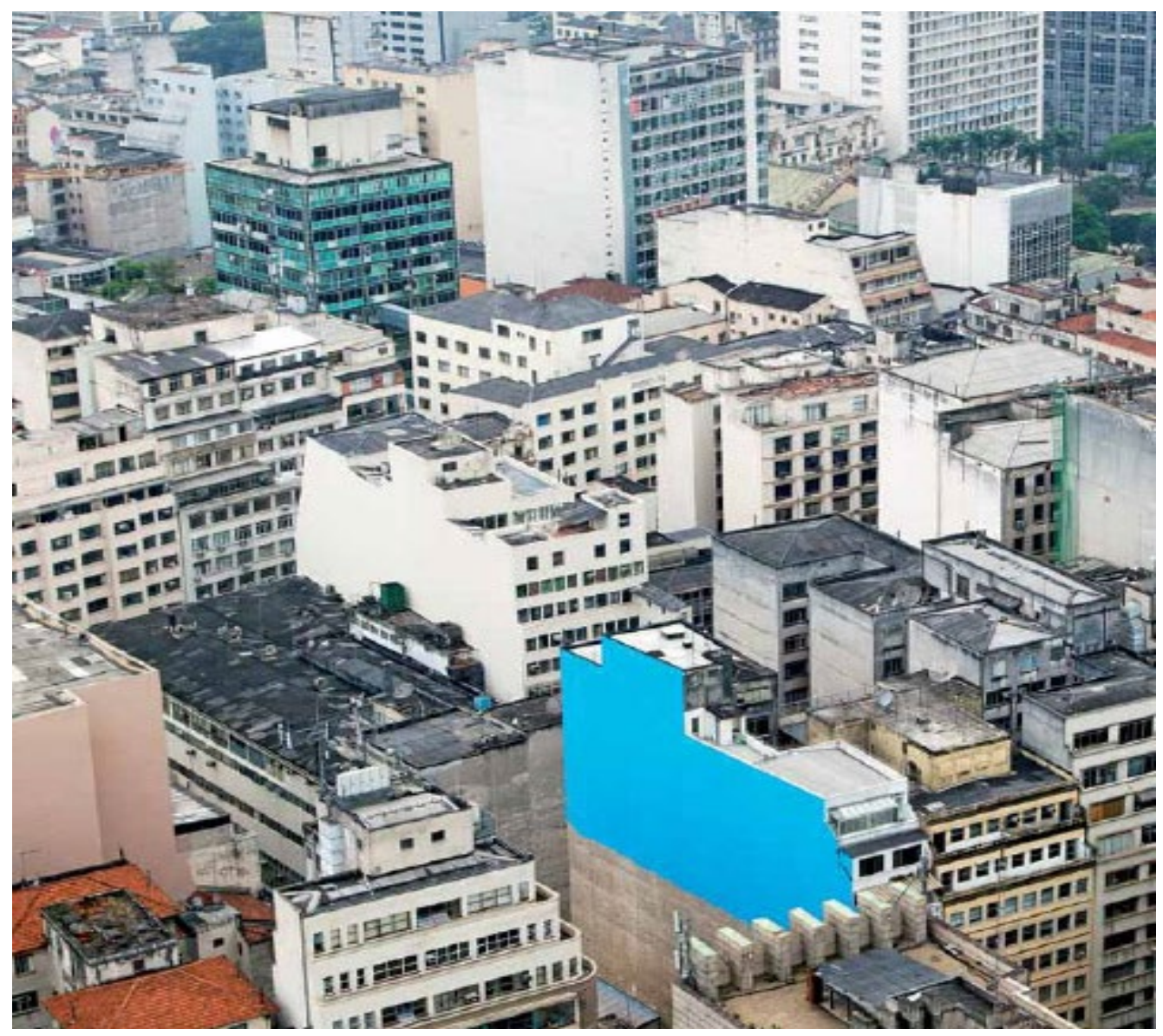

Extravasar os limites da tela e perder o controle à medida que a pintura ganha as ruas era o objetivo do artista costarriquenho Federico Herrero quando começou a pendurar seus trabalhos nas árvores, ou a repintar a sinalização de trânsito nas ruas de San José.

Influenciado pelo trabalho do artista mexicano Gabriel Orozco e pela maneira como este provoca o público para atentar aos acontecimentos das ruas - seja em registros fotográficos nos quais laranjas são caoticamente arranjadas por ele em um mercado, ou distribuídas no entorno do MoMA em Nova lorque para que fossem avistadas através da janela da galeria-, Herrero emprega procedimento semelhante ao destacar a empena cega da esquina da Rua Sete de Abril com Dom José Gaspar, no Centro de São Paulo, como um campo de cor monumental.
O artista impacta a visão do pedestre, bem como a vista distanciada registrada na fotografia aérea, demonstrando domínio do fluxo entre a intimidade do ateliê e a escala monumental do espaço público. Ao manipular a desordenada paisagem paulistana, feita de planos e volumes sobrepostos ao infinito, dela recorta uma tela para aplicar um campo de cor azul que desaba. Sua Catarata parece escorrer à medida que o pigmento azul sofre a ação da gravidade, mas a depender do ponto de vista, pode igualmente flutuar num dia de céu aberto.

Cidades como São Paulo são compreendidas pelo artista como estruturas inacabadas, nas quais sua pintura age reforçando o caráter de abertura da paisagem em eterna reconstrução. Dessa forma, Herrero ativa o espaço para que vibrem suas transformações, revelando que, quanto mais se olha, mais se vê. 
C3.4 Projeto expográfico P33 (2013)

Álvaro Razuk

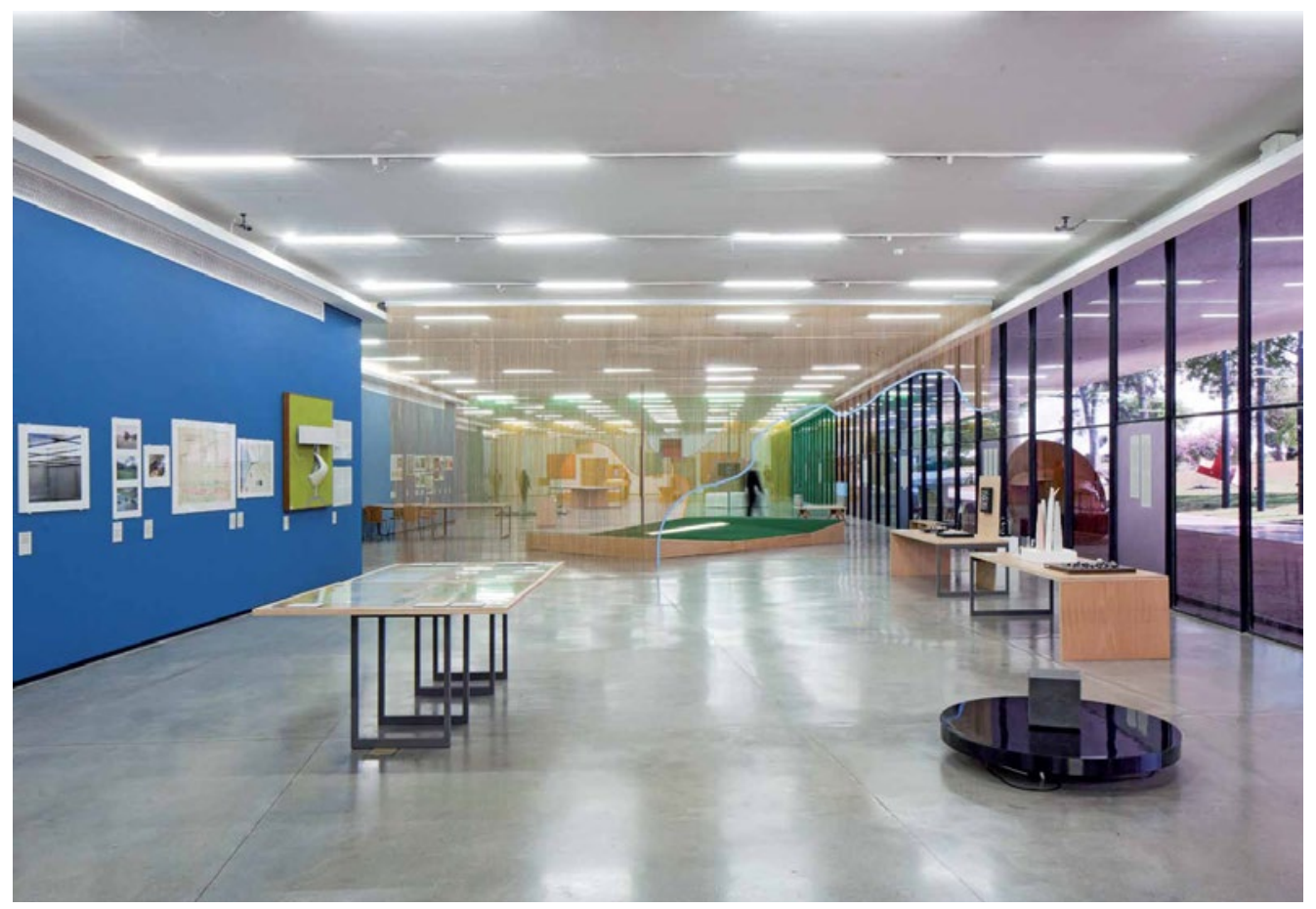

Projeto para o MAM-SP (1983) Lina Bo Bardi

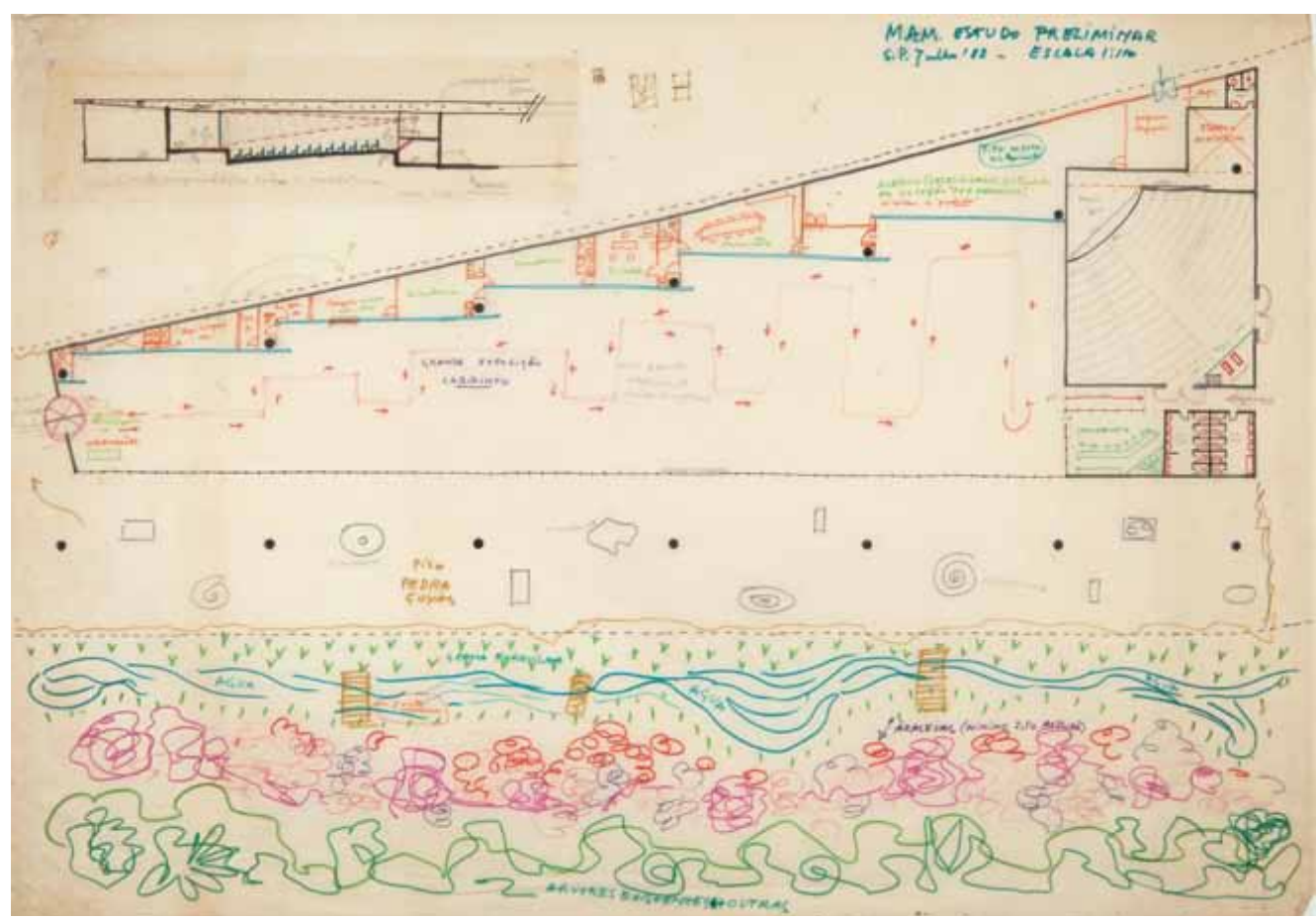




\section{C3.5 Obstáculos (2018) O grupo inteiro}

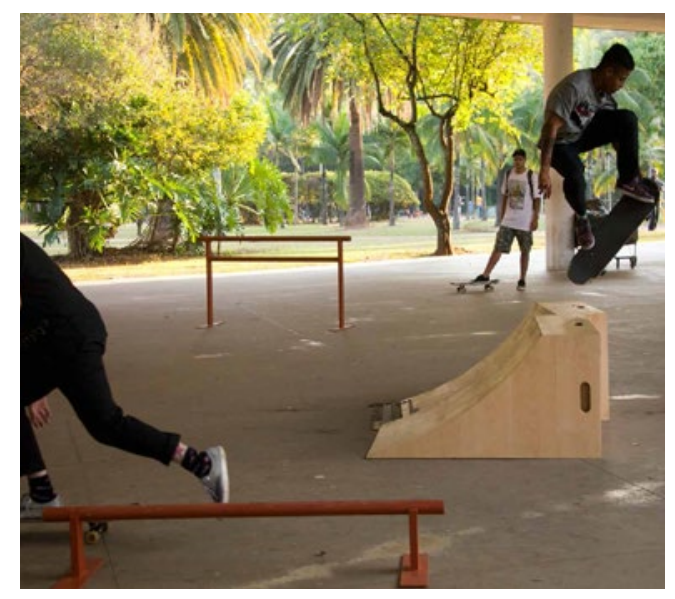

Artista arquiteta desenha rampa de skate Cenotécnico artista interpreta o desenho Artista skatista diz que só funciona em exposição de arte

Tira uma peça para funcionar na rua Artista skatista arrasta em performance para lá

A prova dos nove, palmas

Não era o fim

Skatistas artistas aparecem

Artistas skatistas que estavam lá (MAIA, 2018, p.21)

O haikai, de autoria da curadora Ana Maria Maia, relata a utilização de uma das dezesseis peças que compunham Obstáculo durante a performance Bail 4 (2018), de Guilherme Peters. Trata-se de uma rampa que teve seu desenho informado pelas pistas e circuitos dos skatistas e foi utilizada por Peters durante uma manobra que levou ao colapso uma parede de gesso à qual seu corpo estava amarrado. Erguida para ser espatifada pelo artista-skatista, a parede obstruía a passagem entre a sala de vidro da Aranha (1996), de Louise Bourgeois - trabalho então ausente para restauro - e a Marquise. A abertura simbólica dessa passagem sempre fechada ao público inaugurou o trânsito das atividades elaboradas pelo programa Domingo MAM: nós no meio.

Obstáculos sugere uma ambiguidade semântica que se reflete no espaço ao se transformar de acordo com os deslocamentos

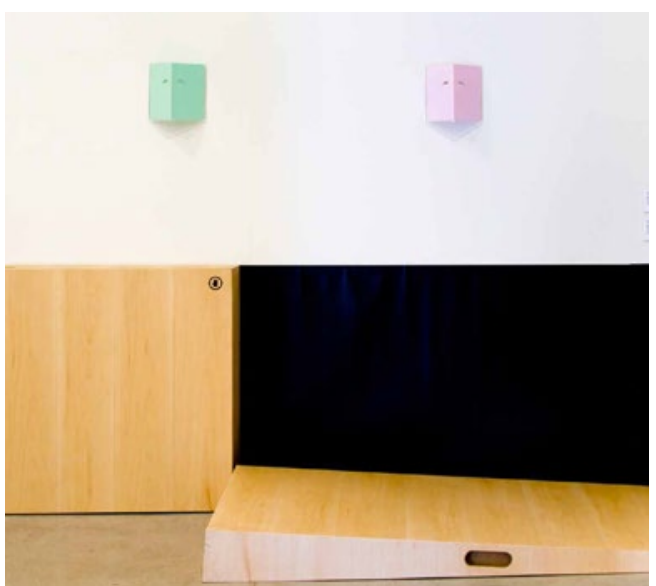

físicos de seus componentes manuseados pelo público. Ambivalentes, barras altas e baixas podiam servir como instrumento de demarcação, guardando a devida distância entre espectador e obra, mas podiam também ser utilizadas para o alongamento do corpo, para exercícios de dança, ou o deslizar de skates na Marquise. Peças em compensado, com formatos diversos, podiam servir como assento em diferentes posturas, apoio para o corpo, mas podiam também ser empilhadas para favorecer a leitura da exposição pelo ângulo de visão de uma criança.

Utilizadas pelo Educativo para organização de atividades dentro e fora do museu, ou espontaneamente espalhadas pelo público, essas peças desconstruíam a ordem do espaço expositivo, com ganhos e perdas para a fruição das obras. Com o tempo, ficaram marcadas e riscadas pelos usos que estimularam.

Retomando o léxico dos usos elaborado por Stephen Wright, é oportuno aqui seu neologismo "usologia" (WRIGHT, 2016, p.161) como definição de um jogo complexo e instável, que envolve a construção e a resistência aos discursos de poder, por meio do emprego de práticas desempenhadas pelos usuários. Uma operação na qual os usuários podem reconfigurar a função de um espaço e, ao mesmo tempo, frustrar tal função - uma dualidade constitutiva da dinâmica dos usos, além de potencial objeto de investigação, segundo o autor, "por diferentes teorias da prática" (WRIGHT, 2016, p.161). 
C3.6 Domingo MAM - Programa especial: Nós no meio (2018) Ana Maria Maia, Educativo MAM-SP e O grupo inteiro

\section{BeyHive}

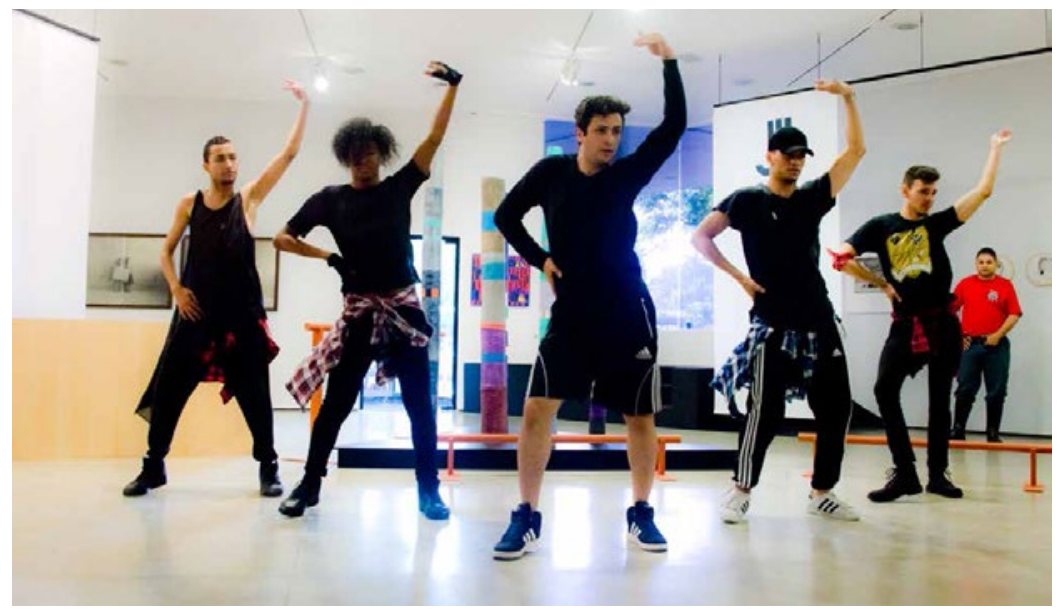

\section{Explode!Zion}

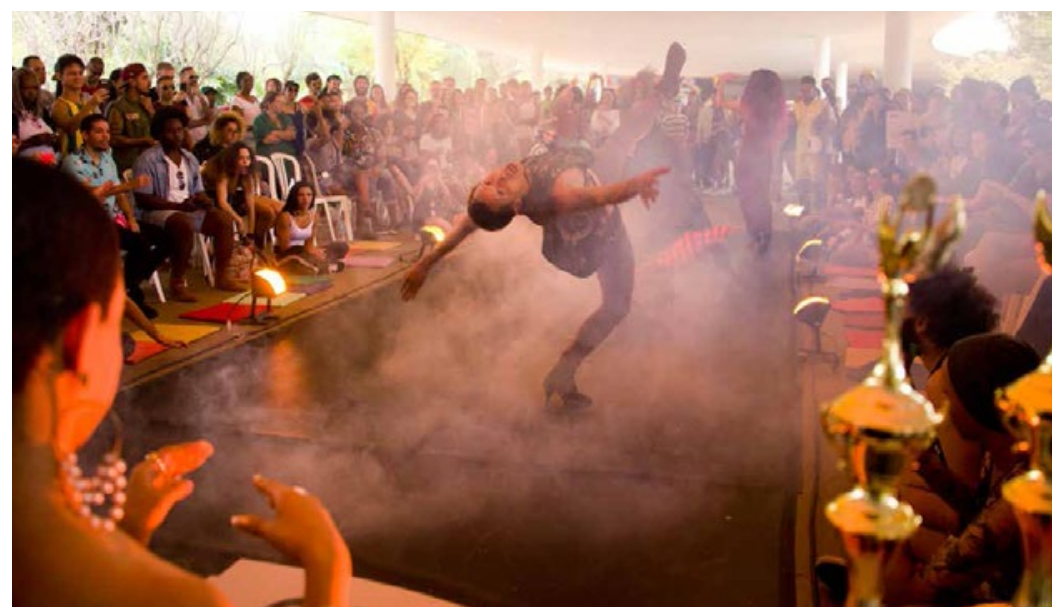

\section{Quando quebra queima}

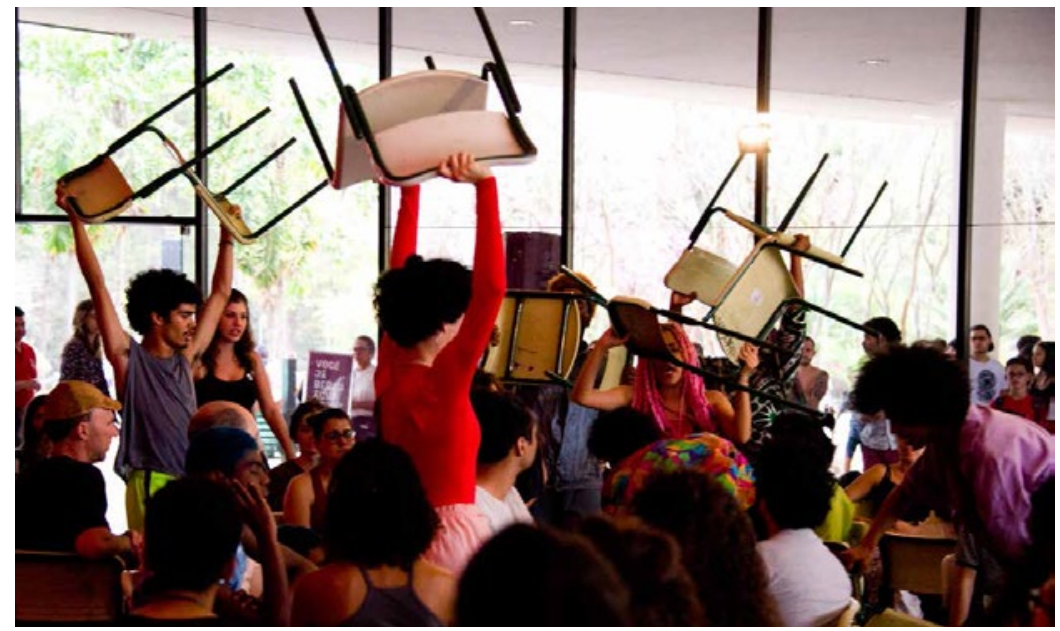




\section{C3.7 O outro, o mesmo (2011) Vazio S/A - Carlos Teixeira}

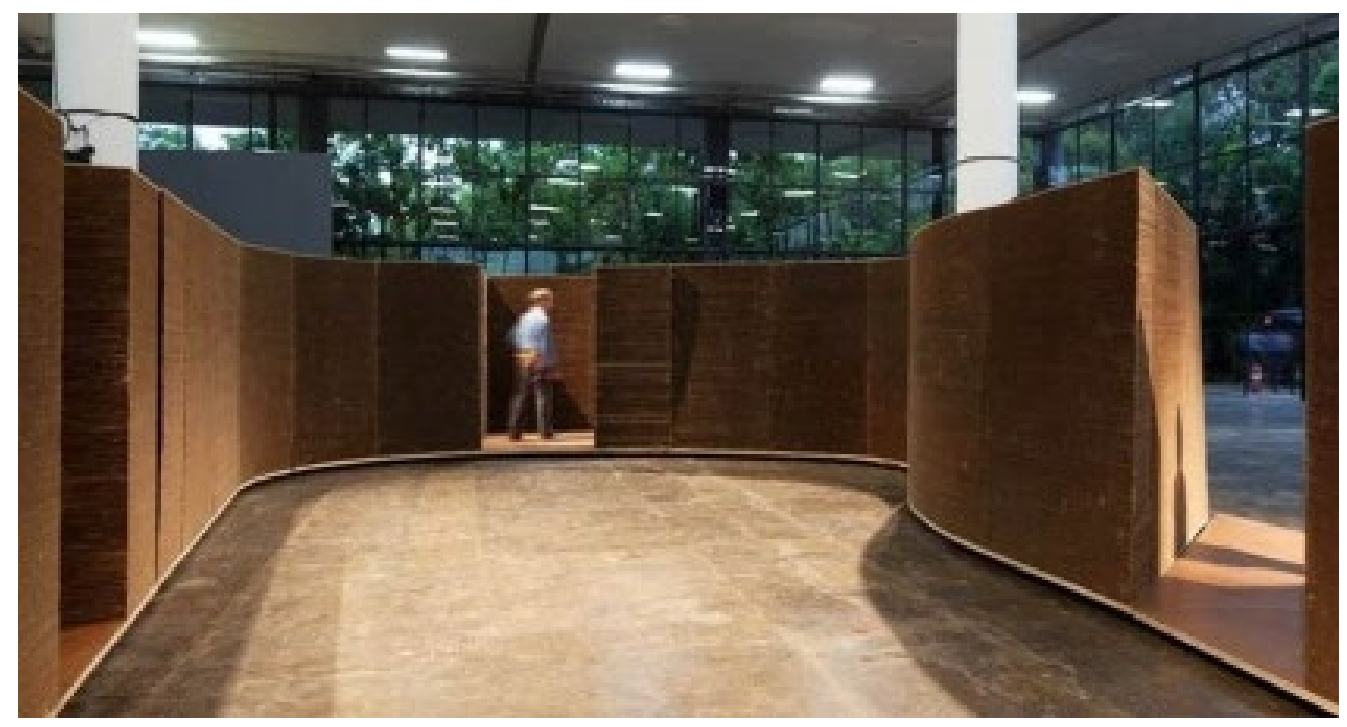

Carlos Teixeira é o arquiteto à frente do escritório mineiro Vazio S/A, criado em 1995, com o qual se estabeleceu no contexto nacional valendo-se de uma prática singular e especulativa, que explora interseções entre urbanismo e cenografia, escrita e intervenções na paisagem, projetos editoriais e de edificações.

Convidado a pensar a ocupação de um dos terreiros - espaços pensados como intervalo e respiro no conjunto da $29^{\circ}$ edição da Bienal de São Paulo, em 2011 -, Teixeira elabora um conjunto de doze módulos articuláveis entre si, com inúmeras possibilidades de composição, a serem manuseados pelo público ou por outros artistas que ali se apresentam.

Os módulos foram construídos com diversas camadas de papelão corrugado empilhado sobre bases com rodizios; o material leve e de textura agradável para o toque fazia com que cada peça estimulasse o corpo a desafiá-lo e explorá-lo, deixando as marcas dessa interação. Sua escala, alta o bastante para barrar a visão, e volume amplo, de forma a envolver os corpos, fazia com que, individualmente, cada peça apresentasse possibilidades de encontro ou de isolamento. A cada posicionamento, novas composições surgiam no andar térreo do pavilhão, que, com seu pé-direito alto e envidraçado, oferecia tanto vistas superiores do conjunto quanto enquadramentos na escala do olhar para quem, em meio a eles, procurasse contemplar o parque. Quando agrupadas, conformavam uma membrana maleável que favorecia o encontro no seu miolo, como uma praça protegida onde aconteceram manifestações, performances e apresentações, de acordo com a premissa curatorial. No dia a dia da exposição, labirintos eram criados para o jogo do público que desbravava seus becos e recantos como numa cidadela.

O outro, o mesmo tornou-se um caso exemplar de elemento arquitetônico e cenográfico indeterminado, que depende de eventos, manifestações e da participação do público para se completar como obra. $\mathrm{O}$ trabalho propôs situações sobre as quais não exerceu controle, muito pelo contrário, se dispôs ao uso sem a pretensão de regulá-lo.

Segundo Paulo Miyada, assistente de curadoria de Agnaldo Farias e Moacir do Anjos nessa edição da Bienal, O outro, o mesmo assumiu a capacidade especulativa da arte que o contexto da Bienal Ihe oferecia, para, por meio de uma obra híbrida, propor uma discussão acerca da sobredeterminação de programas e usos por parte da arquitetura, e assim "iluminar o conteúdo discursivo do projeto e as possibilidades que empodera ao abrir-se a reconfigurações coreográficas de suas peças" (MIYADA, 2011,online). 


\section{C3.8 Estrutura suporte [Support Structure] (2005) Celine Condorelli}

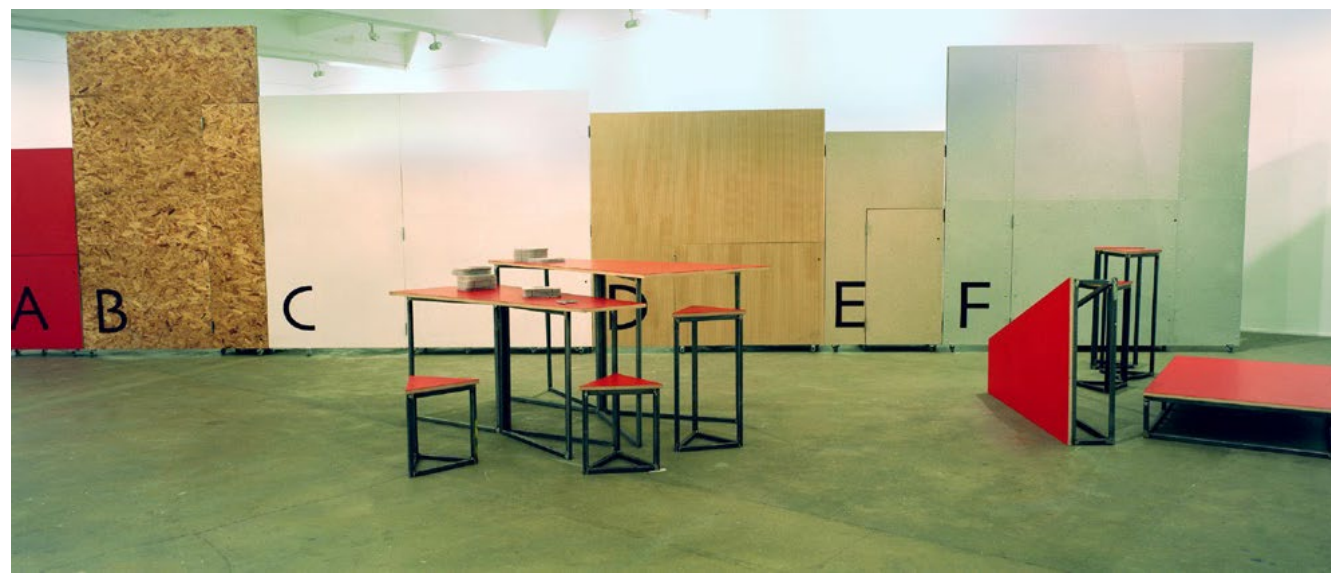

Celine Condorelli é arquiteta de formação, mas cria, com suas proposições, um lugar mais difuso de prática. Através de suas instalações e escritos, formula questionamentos e torções que utilizam como suporte a própria noção de suporte.

$\mathrm{Na}$ arte e na arquitetura, física e discursivamente, um reenquadramento orientado pela lente do suporte, segundo Condorelli (2014, p.7), pode "revelar relações ocultas, e trazer para o primeiro plano compreensões sobre formas de mediação e interface direcionados à construção do lugar, o que não ocorre apenas com a produção de objetos, mas por meio de relações que se possam estabelecer com o contexto".

Estrutura suporte é um projeto de longa duração desenvolvido por Condorelli em colaboração com o artista-curador Gavin Wade. Seu ponto de partida foi a provocação de outro artista, Per Hüttner, que, em sua exposição Eu sou um curador [I am a curator] (2013), na galeria Chinsenhale, em Londres, propôs uma questão de fundo: quais são as intenções do artista, e são essas intenções mais verdadeiras do que a interpretação do visitante?

Para tanto, a galeria recebeu grupos de pessoas sem qualquer experiência prévia com a criação e montagem de exposições para que experimentassem e investigassem o processo curatorial ao longo de um dia, tendo ao seu dispor 57 obras de artistas, além de uma interface maleável com a qual podiam reconfigurar o espaço, guardar e/ou exibir obras e equipamentos. Ao todo, 36 exposições foram criadas, e, em alguns casos, a curadoria foi desenvolvida em grupos.

Segundo Condorelli, Estrutura suporte oferecia um convite e estabelecia uma relação de interdependência que expandia seu caráter de encomenda funcional para tornar-se um elemento que pudesse formular novas perguntas e apontar para “o conjunto de propriedades inerentes à realização de exposições, [...] com suas regras programáveis [...], mas sem desvirtuar a pura alegria de organizar e descobrir objetos e ideias no espaço e em contexto" (CONDORELLI, 2013, p.116).

Estrutura suporte agiu como um disparador, apoiando a relação entre os participantes, gerando reflexões sobre os modos de exibir e a relação das exposições com os espaços e contextos criados. Ao mesmo tempo, deixou visível um registro dos processos instaurados e continuamente reinventados a cada nova exposição, como uma memória das práticas de negociação que ocorrem nos interstícios das estruturas culturais. 
C3.9

Museu de arte de São Paulo. Perspectiva indicando ocupação do Belvedere com esculturas (1957-68) Lina Bo Bardi

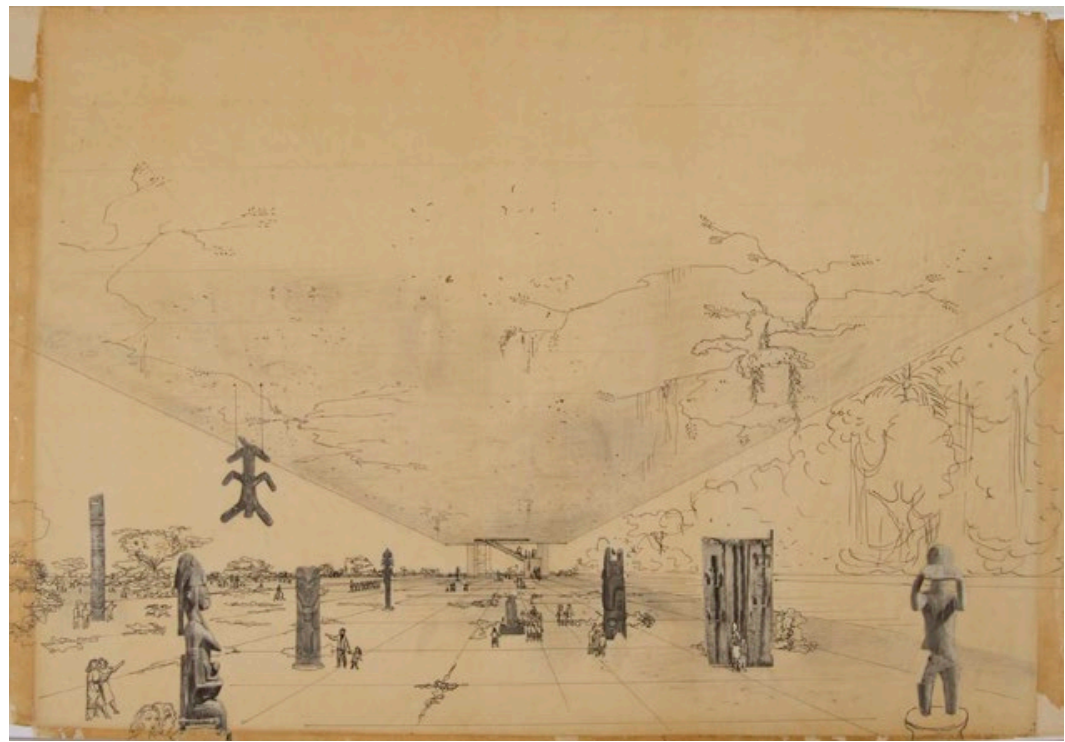

Estudo preliminar - Esculturas praticáveis do Belvedere do Masp (1968)

Lina Bo Bardi

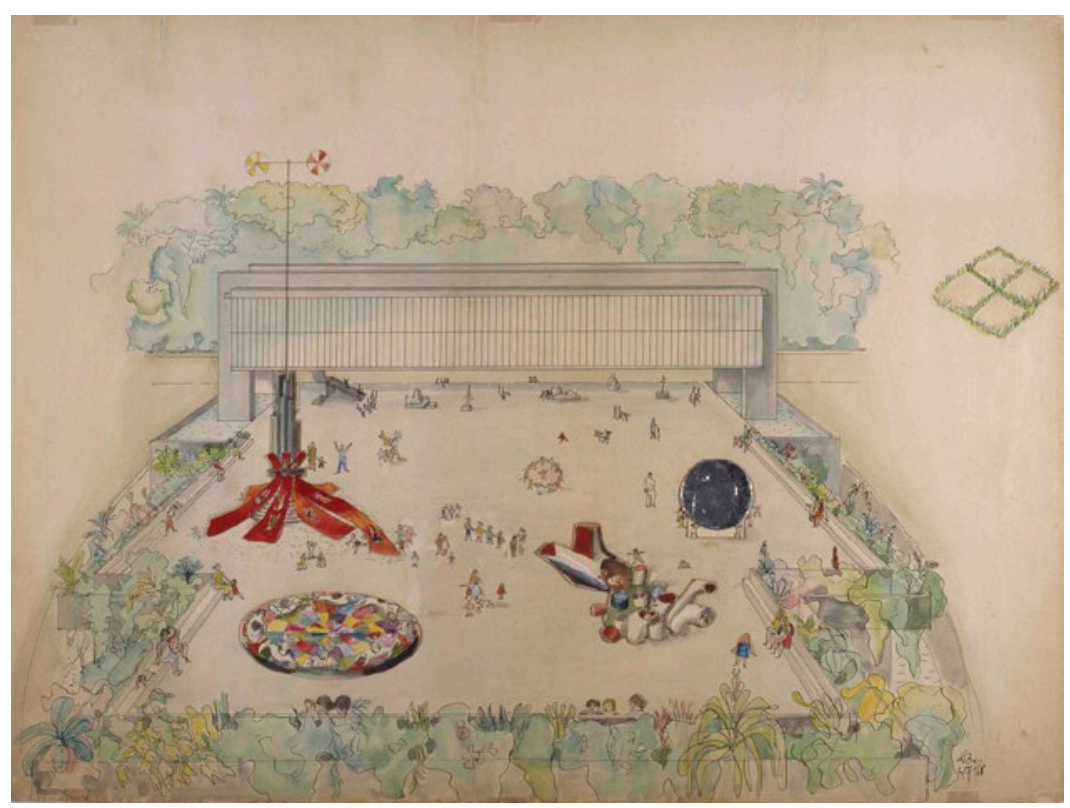




\section{C3.10 Bandeiras na praça (1967) Nelson Leirner e Flávio Motta}

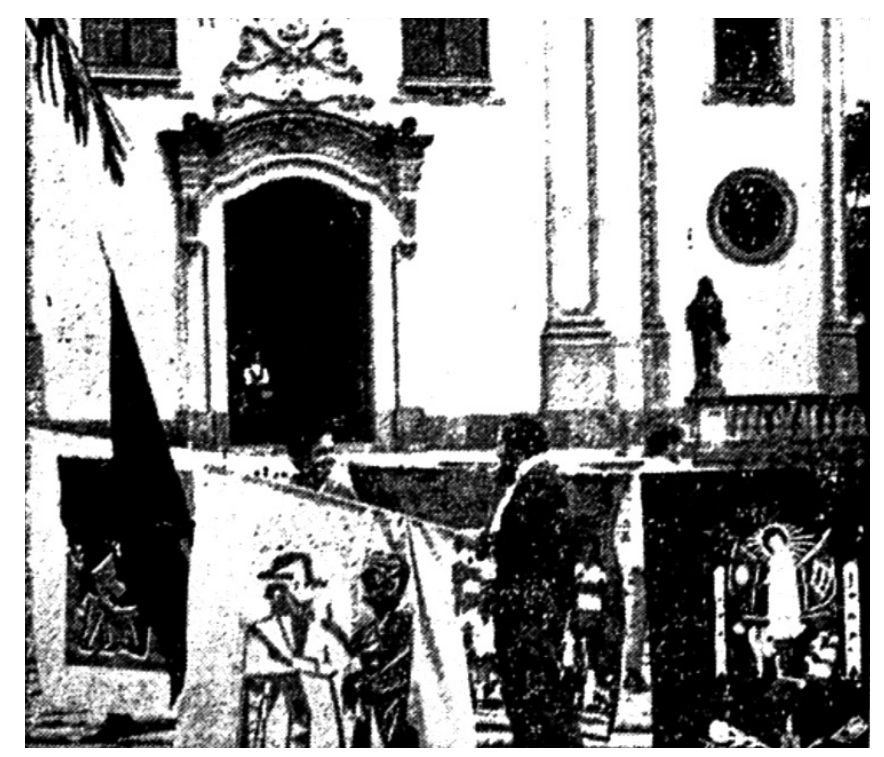

No dia 24 de dezembro de 1967, Nelson Leirner e Flavio Motta levaram uma série de bandeiras para a movimentada esquina da Avenida Brasil com a Rua Augusta, em frente à igreja Nossa Senhora do Brasil, em São Paulo. As bandeiras de um metro e meio por dois metros, confeccionadas em tafetá com impressões em silkscreen, foram estendidas e flamulavam com seu conteúdo que abordava, em seis imagens, dois temas da cultura popular: o futebol, paixão de Leirner, e a vida nordestina retratada pela literatura de cordel, assunto pesquisado por Motta.

As bandeiras haviam sido expostas naquele mês na galeria Atrium - prestigiada galeria num ambiente cultural e artístico ainda incipiente na cidade de São Paulo - e eram vendidas por cinquenta cruzeiros cada. No entanto, não demorou a serem apreendidas por oito fiscais do "rapa", que confiscaram o material dos "infratores dos lucros ilícitos", recolhendo-o para o depósito municipal por "falta de alvará de licença das autoridades competentes" (Folha de S. Paulo, $1^{\circ}$ caderno, 26 dez. 1967, p. 10), além de desobediência a uma lei federal que então proibia o hasteamento de bandeiras.

Pode-se notar que essa ação performática se adensa pela camada discursiva em que a apelação age de modo a explicitar o cerceamento da vida pública e das manifestações na cidade naquele período:

\begin{abstract}
“Precisamos reconhecer que nosso sistema urbano não oferece espaço e tempo à atividade artística. $\mathrm{O}$ espaço não está somente na dimensão das calçadas, ruas e praças, mas também nos decretos e na maneira de interpretálos. Gostaríamos que nossas bandeiras fossem penduradas em locais como a galeria Prestes Maia, a Rodoviária, estações de estrada de ferro, Correios e outros logradouros públicos" (Centro de documentação MASP. Arquivo Nelson Leirner. Bandeiras e Flâmulas. Documento sem data ou autoria.)
\end{abstract}

Bandeiras na Praça se desdobra numa ação análoga que ocorre na Praça General Osório, no domingo do carnaval de 1968, no Rio de Janeiro, para a qual Hélio Oiticica produz a famosa bandeira Seja marginal, seja herói, em homenagem ao bandido Cara de Cavalo, seu amigo morto pela polícia na época.

Com essa ação, os artistas agem em dois tempos com igual potência: a manifestação pública que atinge diretamente os transeuntes, escapando ao âmbito institucional, e sua transferência para um embate igualmente público e amplificado pela circulação do fato nos jornais da época, burlando a censura com seu jogo sarcástico. 


\section{C3.11 Playgrounds (1969) Nelson Leirner}
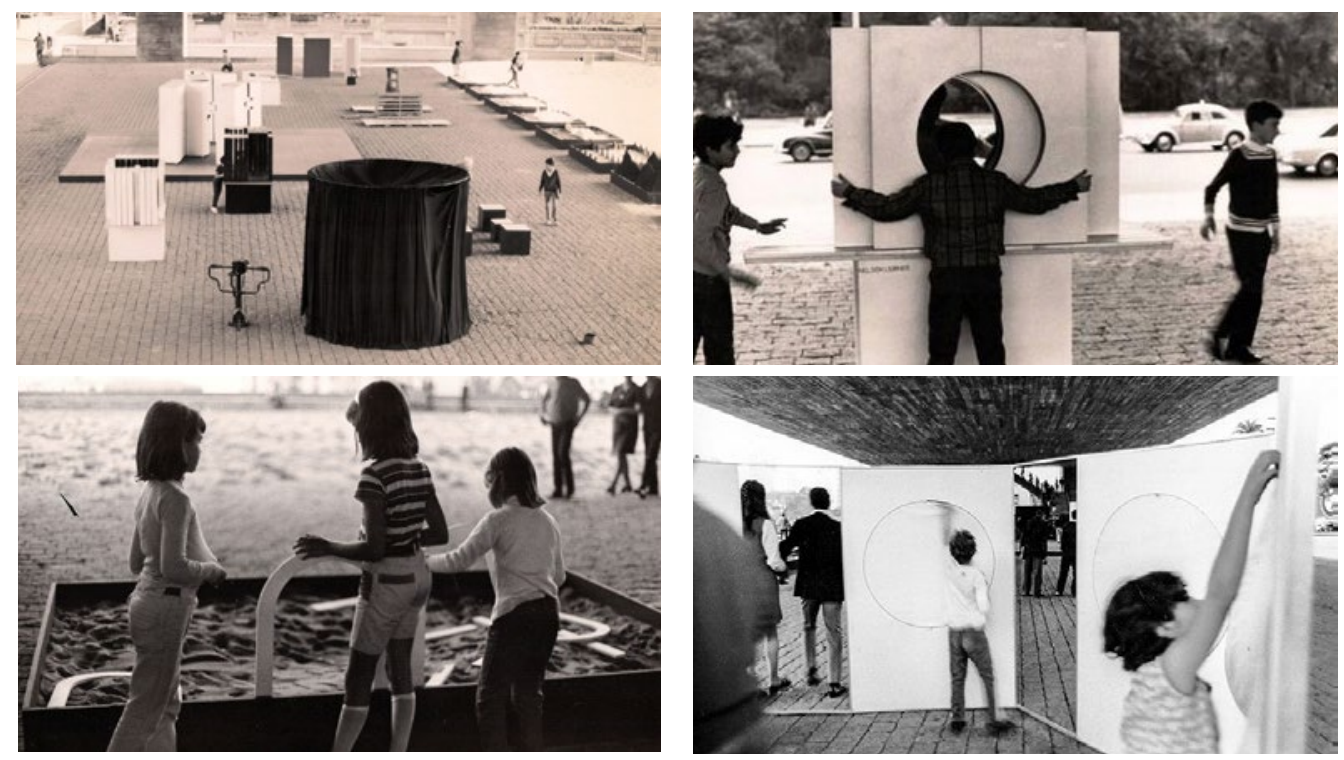

O convite para ocupar o Vão Livre do MASP em sua inauguração era sem dúvida um desafio que oferecia condições únicas para que 0 artista seguisse sua exploração com proposições voltadas à interação. Com o museu recém-inaugurado, abria-se novamente o Belvedere, lugar historicamente associado a eventos públicos, em meio à avenida que se verticalizava e ganhava protagonismo na cidade. Ao mesmo tempo que dialogava diretamente com a rua e a dilatação de seu fluxo, a exposição estava sob o amparo do MASP, que ensaiava pela primeira vez a ocupação do vão como extensão mais pública de seu programa de atividades.

Leirner afirma a potência daquele espaço como espaço para pessoas, e chegou a especular sobre fazer ali "um refeitório, mesas toscas e bancos para vender café [...] um preto e um branco, visualmente era muito bonito. Assim, eu poderia transformar o espaço em algo utilitário" (LEIRNER; PEDROSA, 2016, p. 36).

No lugar do refeitório, Leirner monta Playgrounds, um conjunto de novas peças e outros trabalhos seus que "caberiam num playground". As peças, com sua forma geométrica - "demonstrando que o artista era sensível ao debate levado no campo formal pelo setor Concreto/Neocroncreto" (FARIAS, 1995, p. 60) -, eram abertas a reconfigurações e à imprevisibilidade, provocando o espectador passivo a tornarse público ativo. Trata-se de uma exposição que estava na rua, e ainda assim sob o respaldo do museu. Uma conjuntura que abarcava o público especializado enquanto possibilitava a captura de outro público, alheio à arte. Ambos atraídos pela possiblidade de manusear as peças cuja escala provocava o corpo e despertava a curiosidade.

O aspecto lúdico da exposição e sua inserção no contexto urbano, proporcionada pelo Vão Livre, ecoam as provocações de Leirner ao longo dos anos 1960 em seu ataque à sobrevalorização do artista, à sacralização dos espaços expositivos e à mercantilização da obra de arte.

$\mathrm{O}$ alcance dessas operações se reflete, por exemplo, no léxico de usos elaborado pelo curador Stephen Wright, em recente tentativa de abarcar procedimentos empregados pela arte hoje, que exalta o valor de uso como necessária ferramenta de combate ao "valor de troca" do espaço. Segundo o autor, "o uso representa uma ameaça radical para, pelo menos, três instituições conceituais sólidas da cultura contemporânea: o espectador, a cultura dos especialistas e a propriedade" (WRIGHT, 2016, p. 165).

Valores que o Vão Livre do MASP disponibiliza ao abraçar a cidade e aproximar arte e vida. Usos se cruzam e disputam território num espaço que é mais cidade do que museu, como já predestinava a história desse terreno, ainda que permaneça o desafio de enfrentamento mais franco e permeável entre dentro e fora dos limites do museu. 


\section{C3.12 O Modelo para uma sociedade qualitativa [The Model for a qualitative society] (1968) Palle Nilsen}

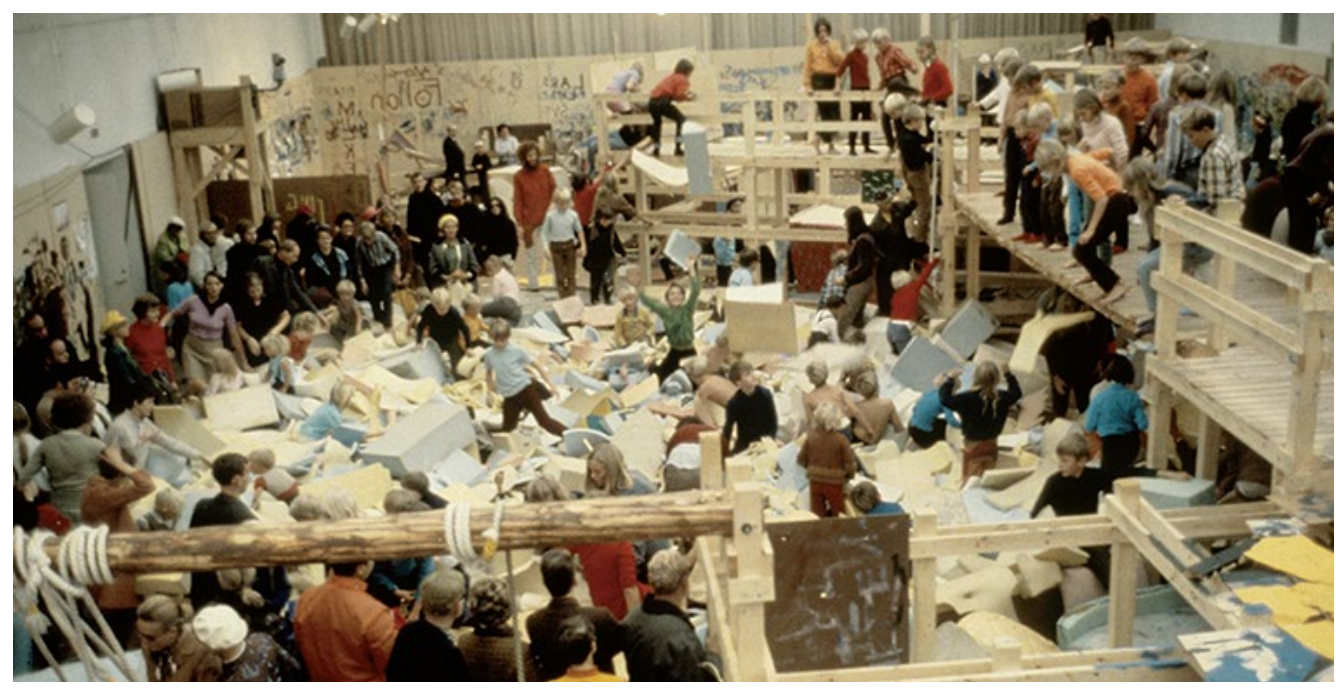

No fim dos anos 1960, Nilsen era um jovem artista que intervia na cidade de Copenhague com o grupo ativista Action Dialogue criando espaços de brincadeira para crianças. Esta era uma maneira de despertar a atenção pública para a necessidade de mudanças no planejamento desses espaços e sua distribuição pela cidade, estimulando um desenvolvimento voltado à imaginação e à criatividade em bairros sem alternativas de lazer.

A criança brinca representando mimeticamente a vida à sua volta, num exercício de compreensão de seu ambiente, reproduzindo as frustrações e os distanciamentos sociais que construímos. Essa constatação de Nilsen, elaborada no texto de apresentação de O Modelo para o catálogo da exposição no Moderna Museet em 1968, culmina com a retórica:

“Mas e se eles pudessem fazer todas as coisas que não tivemos a oportunidade de fazer? Então eles poderiam se tornar eles mesmos. $E$ fazer o que nunca conseguimos fazer" (NILSEN, 1968, p. 116).

Partindo dessa utopia, O Modelo propõe uma desconstrução definitiva do "cubo branco" e da concepção elitista do museu de arte para instaurar um espaço livre, em que a comunidade participasse e interagisse com toda sua potência cultural por meio da presença das crianças.

Transformando a galeria em um enorme e fantástico playground, o espaço provocava o corpo e a liberação de energia - pontes, cordas, espaços para escalar e saltar numa piscina de espumas -, assim como apresentava estímulos sensoriais e experimentais para desfrute individual ou coletivo, tais como: discos para audição em autofalantes, papéis, tintas, tesouras e outros materiais de exploração plástica.

Visitada por mais de vinte mil crianças e por adultos que assistiam à distância estupefatos, o museu foi tomado por um experimento cuja força simbólica residia no potencial de "[...] mudança social e subjetiva que a criança que brinca gera dentro do mecanismo da sociedade [...] com objetivo não de retirar o domínio utópico da arte para o campo antiestético ou ético, mas de tornar o trabalho um motor de mudança social na arte e na vida cotidiana" (RUGAARD, 2014 , p.16). Fato que representou uma ruptura nos modos de exibição da arte habituados a estipular distâncias e fronteiras e a determinar papéis inequívocos entre quem observa quem ou o quê.

Essa ruptura da noção de público ativo e passivo é o que, para Jacques Ranciére, constitui o cerne de uma comunidade emancipada, capaz de interpretar e "apropriar-se da 'história' para fazer dela sua própria história" (RANCIĖRE, 2019, p.25). 


\section{C3.13 Bodyspacemotionthings (1971) Robert Morris}
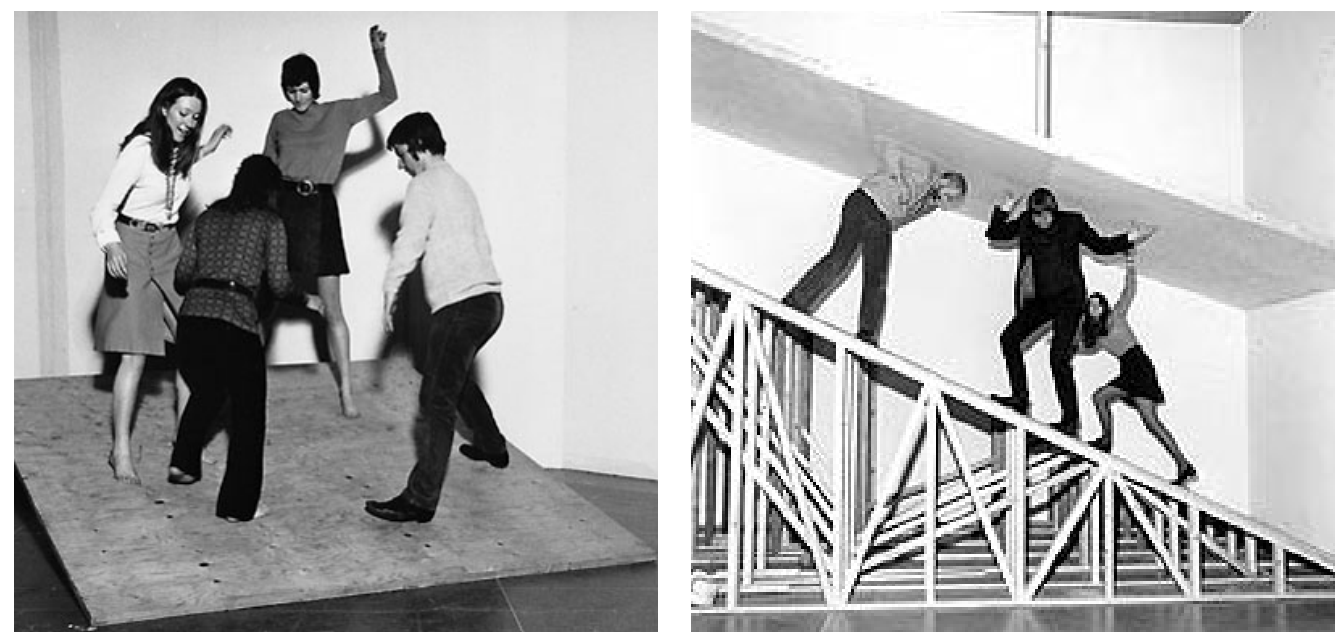

Robert Morris é um artista central para o minimalismo norte-americano nos anos 1960, bem como seus desdobramentos numa produção tridimensional plural a partir de então. Seus trabalhos de composição geométrica simples e seriada, arranjados como variação entre unidade e todo, eram dispostos no espaço expositivo de modo a ativar a percepção sobre o enquadramento da galeria moderna, transferindo a fruição do trabalho, de uma dependência da frontalidade diante de objetos autônomos, para uma apreensão do espaço total e circundante numa experiência de "presentidade" presença como atualidade em processo (FERREIRA; COTRIM, 2006, p. 402).

Questão que adensava também em suas elaborações teóricas publicadas simultaneamente a sua produção, contextualizando seu trabalho e o de uma geração de artistas cuja produção desfazia convenções da forma escultórica e expandia a investigação para além do objeto, voltando-se para processos afetados pelo acaso, a indeterminação e as situações, à medida que também se deslocavam para fora das galerias de maneira a reconfigurar relações entre escultura e uso.

Em Notas sobre escultura parte II [Notes on Sculpture] (1996), publicado na revista Artforum, a frase que encerra o texto resume claramente o procedimento empregado em seu trabalho: “O objeto não se tornou menos importante. Tornou-se menos 'autoimportante'" (MORRIS, 1996, p. 23).

A exposição Bodyspacemotionthings (1971),

na Tate Gallery, em Londres, origina-se de um convite para a realização de uma retrospectiva individual, ao qual o artista responde ocupando vários salões como se fossem partes de um único grande trabalho aberto a situações indeterminadas e direcionado à interação entre público e objetos. Rompendo com a ambiguidade existente entre contemplação e uso, cada galeria apresentava um tipo de arranjo de objetos e materialidades que se predispunham a um tipo de interação lúdica diferente: objetos passivos - pesos e cordas para serem movidos pelo público; objetos mutuamente interativos - secções tubulares nas quais grupos de pessoas interagiam conjuntamente para se deslocarem; e objetos imóveis - rampas e plataformas que instavam o corpo à exploração.

A exposição gerou ocorrências imprevisíveis levando ao seu fechamento cinco dias após sua abertura: “Era de se esperar uma participação ordenada, mas houve um pandemônio" (BRETT apud TOTT, 2013, p. 6).

Reeditada em 2009, no Turbine Hall da Tate Modern - como experimento de revisão dos modos de adesão à participação do público, e de abertura da instituição à imprevisibilidade e ao uso -, o comportamento ordenado do público e a resposta pacificada por parte da Tate despertaram interpretações críticas sobre o papel do jogo, suas regras, restrições e possibilidade de burla, assim como de controle e condutas assimiladas, relativizando o ânimo em torno da participação lúdica e seu contraponto de rejeição à fruição contemplativa de uma pintura. 


\section{C3.14 Playgrounds (1947-1978) Amsterdam Aldo Van Eyck}
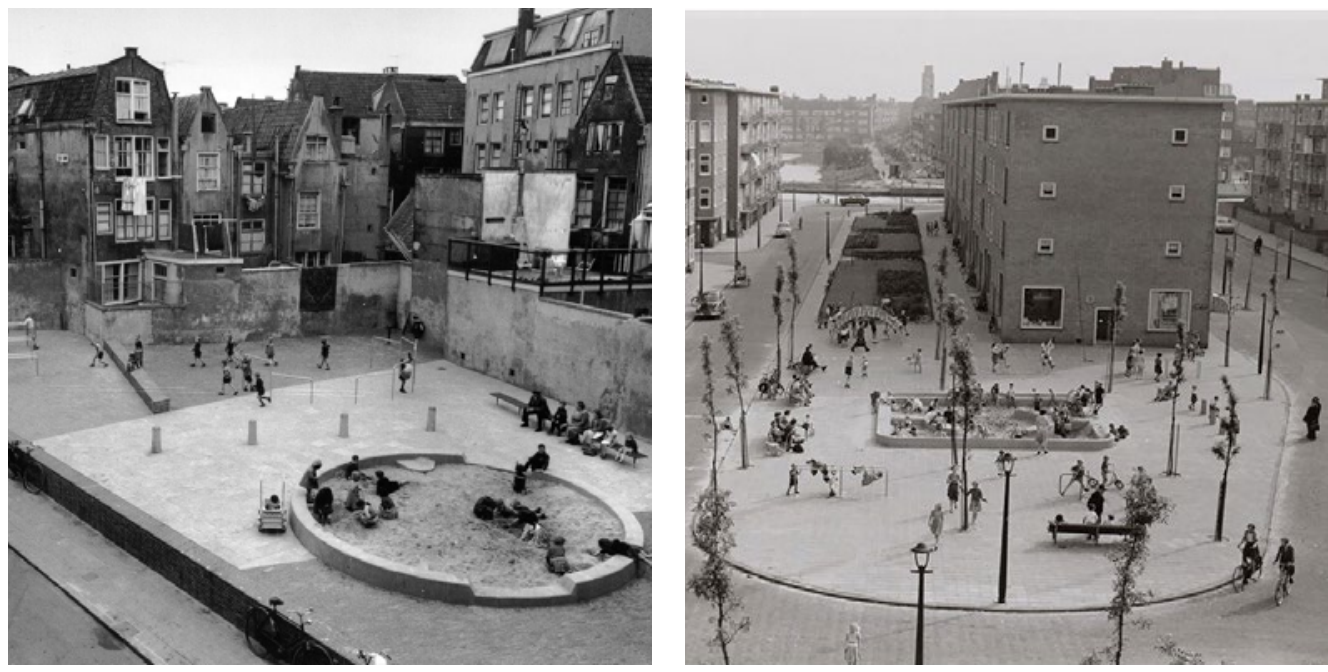

Aldo Van Eyck foi um arquiteto holandês que, atuando na Amsterdam do pós-guerra, manteve uma relação próxima com 0 grupo CoBrA (1948-1951) - acrônimo de Copenhague, Bruxelas e Amsterdam -, um grupo de artistas com quem partilhava o interesse pela expressão espontânea e vibrante dos desenhos infantis, com suas formas estranhas e criaturas fantasiosas, como manifestação entre o consciente e o inconsciente. Após a dissolução do grupo, Van Eyck continuou próximo de Constant Nieuwenhuys - com quem contribui no projeto da Nova Babilônia (1953 -56/1974) - e de Asger Jorn, integrantes do núcleo holandês do grupo, para os quais a noção de jogo adquire grande importância simbólica, informando e dialogando com a proposta do Urbanismo Unitário dos situacionistas.

Em uma conferência em 1962, Aldo Van Eyck reflete sobre o que havia aprendido até então desenhando mais de 400 espaços de jogo para crianças em colaboração com outros profissionais que trabalhavam no Departamento de Desenvolvimento Urbano de Amsterdam. Em sua retórica, apresentou um aparente limite na busca de espaços para alcançar sua ambição de expansão da rede diluindo-a por toda a cidade, mesclando a escala das intervenções, de modo a:

"[...] ter, a cada dois locais de jogo e, entre eles, um número crescente de espaços com uma ou duas paradas para jogar. $\mathrm{A}$ oportunidade para a criança descobrir seu próprio movimento faz parte da própria cidade; A cidade também é um espaço de recreação" (VAN EYCK, 1962, p. 121).

Aproveitando terrenos vagos da cidade, conquistando áreas em parques, conjuntos habitacionais ou expandindo calçadas, esses espaços de imaginação e jogo cresceram proporcionalmente à natalidade da geração de babyboomers, atingindo quase 700 pontos nos anos 1970 .

Cada playground era diferente do outro, adequando-se ao desenho e às transições de escala entre espaços residuais e os bairros, sempre utilizando um vocabulário de soluções semelhantes. Os materiais construtivos eram simples - um reflexo das condições econômicas do pós-guerra - e as formas eram abstratas, reproduzindo arquétipos elementares como tubos metálicos dobrados em arcos ou cúpulas, blocos de concreto em módulos alveolares com alturas diversas, caixas de areia cercadas por muretas e guias baixas que, ao mesmo tempo que se dispunham para o jogo, organizavam os ambientes e funcionavam como mobiliário urbano "real" e aberto, propício à exploração infantil. Afinal:

"As crianças sabem utilizar todos os elementos da cidade. Todos os objetos construídos, e todas as superfícies nas quais puderem rastejar ou escalar" (VAN EYCK, 1962, p. 121). 


\section{C3.15 A grande vaca mecânica para o MASP (1988) Lina Bo Bardi}

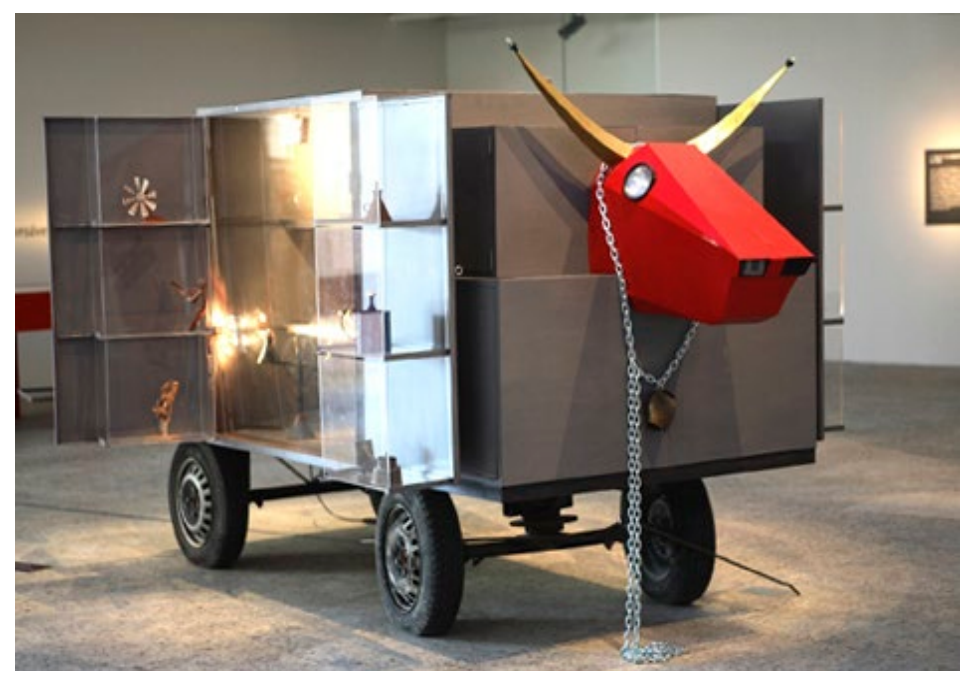

A grande vaca mecânica foi esboçada por Lina Bo Bardi em 1988 - em colaboração com Marcelo Suzuki -, mas só foi executada quinze anos mais tarde, quando, baseada parcialmente em seus croquis e desenhos técnicos, integrou a exposição retrospectiva Lina Bo Bardi, arquitecto (2004), em Veneza, ocupando a sala central da exposição dedicada aos objetos criados pela arquiteta.

Pensada originalmente para uma exposição a ser realizada no MASP, Bardi a definiu como: "objeto escultural - instalação de som e luz - contêiner - exibição articulada de objetos de artesanato folclórico brasileiro - 'o quarto dos milagres' " (BARDI, L. apud SÁNCHEZ LLORENS, 2010, online). Uma somatória de classificações que revelam a maneira de pensar característica de Lina Bo Bardi que abarca, em sua prática, o trânsito por uma multiplicidade de papéis: arquiteta, designer, pesquisadora, curadora, editora e educadora.

A vaca é apropriada como um bicho síntese da cultura nordestina, dada sua importância referencial para o sertão, onde serve para carregar carga, arar, e fornecer o leite, a carne e o couro. Em seu desenho, a forma do animal é geometrizada e compõese de volumes retangulares feitos em lata. De suas entranhas, surgem compartimentos e gavetas nos quais se dispunham os mais variados objetos, brinquedos e utensílios da vida cotidiana com os quais Lina Bo Bardi se deparou em sua imersão na cultura material brasileira, e da qual extraiu um encantamento determinante para elaborar rupturas entre a alta cultura elitista, baseada numa historiografia hegemônica, e a negligenciada cultura popular.

Sobre rodas, o grande animal metálico de 3.00 metros de comprimento por $1.10 \mathrm{~m}$ de largura e $2.10 \mathrm{~m}$ de altura poderia se deslocar pelo museu e compor ambientes expositivos junto ao arranjo de suportes e cabos que conformariam uma cerca na qual se poderiam fixar pôsteres. Sua cabeça é vermelha, seus chifres dourados, suas tetas azuis servem como um tanque para bebidas, e seus olhos são faróis automotivos acionados por um motor e um circuito elétrico que também fazem funcionar um rádio e suas antenas, tornando-o um grande brinquedo coletivo, mecânico, brilhante e colorido.

A grande vaca mecânica é uma peça inusitada, divertida, e disponível à exploração como um gerador intuitivo de descobertas. Ao se deslocar, faz barulho, pisca, brilha, criando eventos carregados de uma teatralidade performática que desmonta qualquer pretensão de neutralidade do espaço expositivo, proporcionando uma construção participativa a partir dos objetos que contêm em seu interior, como um jogo coletivo para criação de uma exposição que se transforma e altera o ambiente a cada jogada. Nela, o conteúdo e seu contêiner se confundem e se entrelaçam. 


\section{C3.16 Zero ao infinito [Zero to infinity] (1968-) Rasheed Araeen}

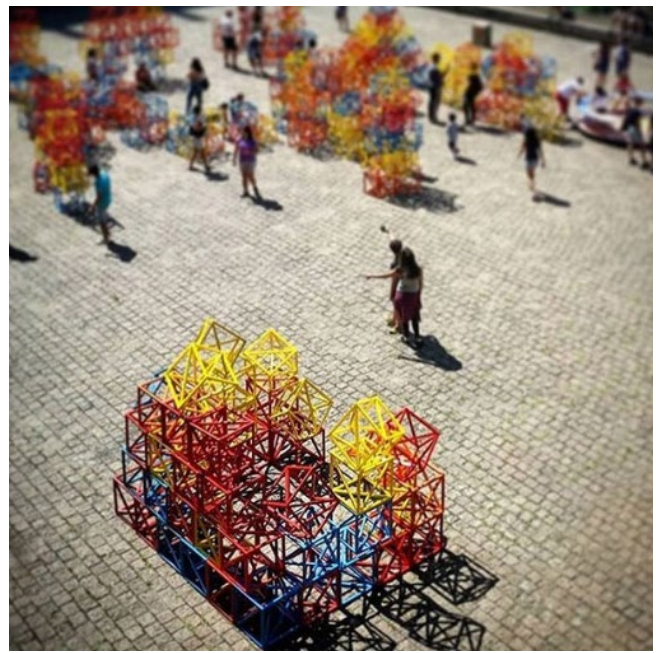

Inicialmente chamada Biostructural play [Jogo biostrutural], Zero ao infinito parte de um conjunto de cubos conformado por suas arestas e por uma diagonal em cada face, construídos com hastes de madeira leve. Para a montagem no MASP, quatro conjuntos de cem cubos foram produzidos com pintura nas cores amarelo, laranja, vermelho e azul, dispostos no subsolo e no Vão Livre.

As regras são simples. Parte-se de uma forma regular de $4 \times 4,6 \times 6,8 \times 8$ cubos, e assim por diante, criando áreas simetricamente divisíveis, para serem manuseadas e transformadas pelo público. Ou seja, a abstração da forma simétrica, rígida e estática, é quebrada pelas pessoas comuns que a tornam assimétrica, recombinando as peças em variações infinitas, num movimento constante. Uma proposta que encontra paralelo no conceito de "quebra de simetria" elaborado também pela física quântica, rendendo o prêmio Nobel de Física de 2008 ao grupo de cientistas japoneses que conceberam o esquema matemático que demonstra como as partículas elementares apresentam uma quebra espontânea de simetria.

Araeen é um engenheiro civil paquistanês que se mudou para Londres nos anos 1960 para seguir a carreira artística, incialmente produzindo uma série de estruturas associadas à produção minimalista. Uma definição que o artista passa a contrapor com um trabalho impregnado por questões identitárias assumindo um viés político em sua produção direcionada à crítica da relação indissociável

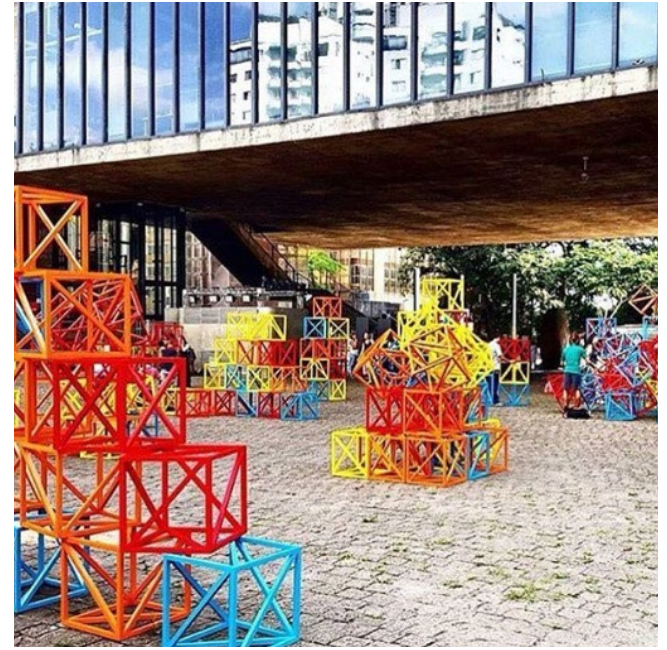

entre modernidade, o imperialismo inglês e o racismo institucional que vivenciava. Sua confrontação se expressa numa variedade de meios, inclusive em manifestos como Black Manifesto (1975-1976), e na curadoria de uma exposição paradigmática na Hayward Gallery, A outra história: artistas afro-asiáticos na Inglaterra do pós-guerra (1989).

Para o artista, essa produção é uma extensão conceitual de suas estruturas, a medida em que propunham uma aliança entre o papel do artista como autor e o público como agente criativo da obra, atacando, assim, o paradigma modernista de centralidade do objeto e de autoria por meio da inclusão do público.

A imaginação como condição emancipatória do jogo envolvido no manuseio de Zero ao infinito confere vantagem às pessoas e às crianças, que manipulam as peças sem inibição ou preconcepção, de uma maneira exploratória e livre.

Segundo o artista:
“Embora esses projetos sejam geralmente entendidos em termos de participação, 'participação' não é a palavra certa aqui, porque significa que você está permitindo que as pessoas entrem no seu trabalho, que já foi concluído, e elas se tornam participantes dele. [...] eles não envolvem apenas a participação do público, mas também sua criatividade" (ARAEEN; AIKENS, 2018, p.208). 


\section{C3.17 Peça de conversação [Conversation Piece] (2016) Celine Condorelli}

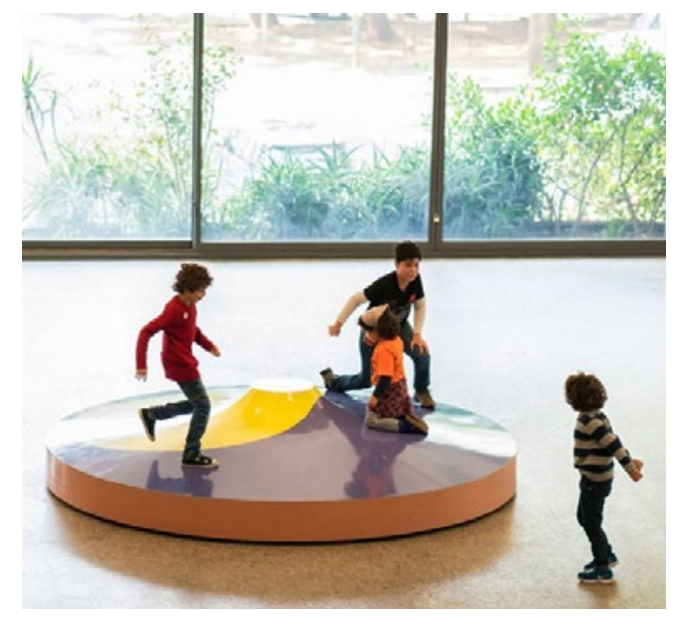

Celine Condorelli descreve seu fascínio a respeito de como se dá o encontro com um objeto ou obra de arte, e como, desse encontro, uma relação é estabelecida através da maneira como ele é disposto, mediado e mostrado. Sua exposição é capaz de gerar proximidade e curiosidade? Como se relaciona com o copo? Desperta o desejo de explorá-lo, girá-lo ou dar um giro em torno dele? Pode ser tocado? Como se descortinam seus detalhes? E, por fim, o que ele tem a nos dizer? Segundo Condorelli:

“É preciso se considerar não apenas
os termos do que parece intrínseco
aos objetos, mas também o que esses
objetos são capazes de suscitar, o que
exibem e como definem seus horizontes
de possibilidade: é sob essas condições
que os sistemas de valor tomam forma,
ideologias são reveladas, políticas
promulgadas e a estética é expressa”
(CONDORELLI, 2009, online).

Essas questões a conduzem a pensar o 'display' expositivo ou os modos de se desenhar exposições como uma prática artística, mas também arquitetônica. Uma prática que afeta de maneira determinante como as pessoas se relacionam com as obras e como se estabelecem camadas de leitura e percepção das obras. Algo fortemente presente no legado Lina Bo

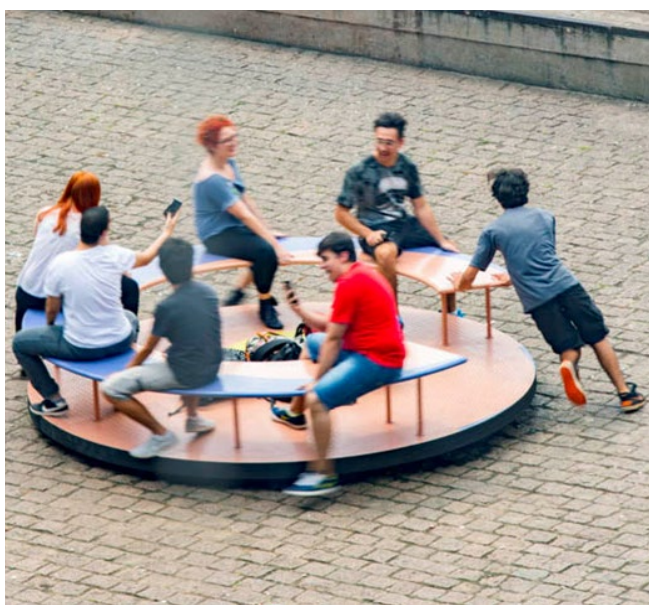

Bardi e seu pensamento sobre museus, expresso de maneira categórica no MASP, principalmente através da maneira como os cavaletes de vidro criam um ambiente partilhado de exploração, no qual os artefatos culturais adquirem uma nova condição de proximidade com o público, possibilitando uma exploração que se desdobra em diversas camadas de apreensão. Um ambiente onde se pode dizer que a arte não é exposta, mas se dispõe à fruição.

Retomar o desenho do carrossel realizado em duas peças por Condorelli, uma dentro e outra fora do espaço expositivo - significava revisitar o pensamento de Lina Bo Bardi como afirmação da liberdade, conforme sugeriam seus ensaios de ocupação do Vão Livre.

Esses projetos referenciais e as instalações por eles motivadas ensejam museus mais democráticos, como espaços que delegam ao público autonomia e corresponsabilidade como exercício do comum.

Peça de conversação constitui, portanto, uma maneira de ver as coisas que altera a relação entre o que é exibido, quem observa, e o ambiente, o que, segundo Condorelli, instaura uma maneira não verbal de conversa entre pessoas através de uma forma convidativa que apela ao instinto corporal, e não apenas aos olhos ou ao intelecto, para construção de sentidos. 




\section{Considerações finais}

Ao longo de seus três capítulos, esta tese se move pelo campo arquitetônico para interrogar sua potência como forma de conhecimento, como ação, como intervenção engajada e ética e como campo no qual pesquisadores implicados possam encontrar lugares estratégicos para suas especulações. Tais investigações são sustentadas pela hipótese de que categorias colapsam, como manifesta a provocativa epígrafe de Robert Smithson que abre este trabalho.

A arquitetura, portanto, ao se desprender de uma agenda de preservação disciplinar pode passar a uma outra condição epistemológica. Essa é a questão de fundo que atravessa esta pesquisa que repassa as rupturas empreendidas pelas práticas artísticas dos anos 1960, para detacar o modo como o processo desencadeado nesse período problematiza os limites da arte com a arquitetura reverberando também em questionamentos e ensaios produzidos por gerações de arquitetos desde então.

Um oportuno exemplo são os três textos que Bernard Tschumi escreve para a revista Artforum, introduzindo os números dedicados à arquitetura que foi convidado a organizar, entre dezembro de 1980 e setembro de 1981. Neles, Tschumi procura examinar os limites da arquitetura como marcos necessários sem os quais a disciplina se desmantelaria. Sua crítica ao formalismo e sua sedução por obras à margem da disciplina, que assumem os paradoxos e contradições do campo, não representavam para o arquiteto um cancelamento dos limites da disciplina. Muito pelo contrário, seu esforço com esses textos é justamente redefinir tais limites diante do debate corrente naquele momento, em que a revisão crítica pós-moderna resultava numa intensa produção teórica em diálogo com um contexto cultural abrangente. 
O cenário apresentado por Tschumi no texto "Arquitetura e limites I" (1980) posiciona o campo da prática e da crítica arquitetônica entre duas abordagens recorrentes, uma que se "volta para questões sociais, culturais, políticas e programáticas mais gerais; outra [...] [que] concentra-se em fatores como estilo, técnica e outros" (TSCHUMI apud NESBIT, 2006, p. 174). Seu ataque recai também sobre a dualidade presente nos trânsitos entre arte e arquitetura, em curso naquele período, qualificando-a como um fenômeno de inveja recíproca, desencadeada por uma atração conservadora de ambos os campos pela liberdade artística e a utilidade arquitetônica, que referendam um entendimento equivocado, em sua perspectiva, uma vez que "se o ato de construir tem uma relação com a utilidade, a arquitetura não tem necessariamente” (TSCHUMI apud NESBIT, 2006, p.174).

Mas experimentações e provocações aos limites disciplinares ganham maior complexidade e intensidade quando, a partir dos anos 1990, a arte site-specific deixa de significar apenas a criação de objetos e passa a propor situações e encontros que ampliam seu vínculo com a vida e o cotidiano, assumindo um engajamento próximo dos contextos sociais nos quais se inscrevem para oferecer serviços e agir de modo propositivo e “útil”, como examinado no primeiro capítulo.

Esses desdobramentos, posteriores aos textos e trabalhos conceituais de Tschumi, reverberam recentemente, quando se constata um descolamento do imperativo da construção e da edificação como sustentação máxima da disciplina, efeito percebido com mais intensidade após a ressaca do período de exacerbação formal para o qual a arquitetura pósmoderna refluiu na virada do século XX.

O que se nota, desde então, é a gradual constituição de um campo ampliado de práticas, procedimentos e circuitos de informação e comunicação, que possuem uma sensibilidade comum entre as experimentações artísticas e arquitetônicas. O que parece representar um novo ciclo de distensão dos limites do campo arquitetônico, tendo em vista que processos de produção, contextos de intervenção e camadas discursivas e críticas conquistam maior protagonismo em um momento no qual a arquitetura 
parece rever seus compromisso éticos e políticos.

Por essa razão, em última instância, fazer um levantamento bibliográfico e cruzá-lo com estudos de caso que tratassem desse movimento de aproximação entre campos parecia não passar mais por uma questão de fundo exclusivamente formal, em que a arte produziria esculturas arquitetônicas, enquanto arquitetos responderiam com edifícios esculturais.

Abordagens conceituais, estratégias de ação e de representação configuram hoje um campo de práticas que se tornam mais e mais semelhantes no ambiente cultural global, ambiente no qual arte e arquitetura se entrecruzam.

A hipótese proposta por Anthony Vidler, ao transpor o conceito de campo ampliado para a arquitetura, ainda que aponte para as ambiguidades entre o espaço construído com finalidade estética e o espaço construído para servir funcionalmente, aponta para o problema que o cancelamento da "divisão entre o espacial e o textual” (VIDLER, 2013, p. 244) coloca para a distinção da especificidade entre os meios.

Sua aposta em um novo modelo crítico para interpretação do programa arquitetônico, conforme examinado ao longo do capítulo 2 , rende importante reflexão sobre como o projeto passa a absorver novas estratégias de concepção, no sentido de uma crítica institucional e do alargamento da prática em relação a processos participativos mais inclusivos. Com isso, o projeto, como fundamento disciplinar, é revigorado por uma ampliação de seu repertório de procedimentos afirmando o valor de uso como conquista para a produção de um sentido coletivo.

Mas a noção de um campo ampliado arquitetônico, com limites incertos e em negociação para a reconstrução dos fundamentos da disciplina, como sugere Vidler, parece agir também de modo reverso, como se condenasse uma produção à margem, a uma indeterminação que não encontraria correspondência nem na arte, nem na arquitetura. Esse paradoxo significaria um enfraquecimento das práticas em sua tendência de convergência, a partir da neutralização das potências específicas desses campos, e da arquitetura em particular, onde a 
última seria descaracterizada ao se distanciar de seu saber específico fundamentado na aplicação de um conhecimento técnico construtivo.

Assim, se a arte consegue hoje estabelecer fortes vínculos com o real, construindo situações e atuando numa esfera micropolítica, junto com entidades e instituições, experimentando novas formas de relações sociais, a arquitetura, de modo análogo, estaria experimentando novos papéis diluídos em ações cotidianas e em práticas sociais nas quais se engaja desenvolvendo novas ferramentas que valorizam processos ao invés de questões formais.

Diante desse possível marco de reconfiguração nas relações entre as maneiras de fazer e as formas de visibilidade do fazer dessas práticas estéticas, Jaques Rancière pontua que arte e arquitetura compartilham o risco de se tornarem um substituto que produz representações incertas, ou encenações esvaziadas de um sentido de comum em face do esvaziamento da capacidade efetiva de renovação política para uma partilha do sensível.

Defendendo a arquitetura como forma de conhecimento, e não como produção de edifícios, o filósofo francês recorre à necessidade de produção de imagens e novos cenários possíveis que possam gerar interpretações e originais traduções do comum.A formulação de Rancièrer, endereçada aos arquitetos, é aqui interpretada como uma reivindicação para a constituição de não-sítios, provancando a arquitetura a se pensar também como espaço para hesitação, para o enfrentamento de ambiguidades e para espelhamentos entre real e ficção como produção de interferências críticas.

Nesse sentido, a epistemologia do espaço, tal como proposta por Lefebvre e absorvida pela crítica arquitetônica, a partir dos anos 1990, poderia significar uma superação desse dilema para a constituição de um campo híbrido da prática, como proposto por diversos autores abordados ao longo desta tese, que passaram a empregar o termo prática espacial crítica em suas análises. Uma literatura que, quando cotejada, favorece análises e interpretações de uma produção mais difusa e que nega categorias sedimentadas, ocasionando rebatimentos nos parâmetros que informam 
instituições de ensino e pesquisa, órgãos de regulação profissional, circuitos de publicização e comunicação, muitas vezes cruzando essas plataformas de modo a explorar múltiplos meios para sua formalização no mundo, mobilizando processos pedagógicos, curadorias, ativismos, instalações, trabalho em rede e até edifícios.

A investigação bibliográfica reportada às práticas espaciais críticas aqui esmiuçada, antes de representar uma tentativa de afirmação dessa terminologia, sob o risco de criar mais uma categoria, ou fragmentação desnecessária, procurou aprofundar os termos da investigação de Lefebvre e sua pertinência interdisciplinar, tendo em vista o estágio atual em que a globalização demanda entendimentos mais complexos para o enfrentamento das espacialidades contemporâneas, e no qual práticas estéticas convergem na tentativa de restabelecer um vínculo social para ocupar uma esfera pública de debates e de práticas. 



\section{Referências Bibliográficas}




\section{Livros, artigos e teses}

ALLEN, Stan. Condições de Campo (1999). In: SYKES, Krista A. (org.). O campo ampliado da arquitetura. Antologia teórica (1993-2009). São Paulo: Cosac Naify, 2013, p. 91-103.

AULT, Julie (ed.). Show and Tell: A Chronicle of Group Material. London: Four Corners Books, 2010.

AULT;BECK. Alternative New York. In: Critical Condition. Selected Texts in Dialogue. Essen: Kokerei Zollverein/Zeitnössische Kunst und Kritik, 2003.

AURELI, Pier Vittorio. The Project of Autonomy. Politics and Architecture within and against Capitalism. New York: Princeton Architecture Press, 2013.

AURELI, Pier Vittorio; ORAZI, Manuel. The Solitude Of the Project (2006). In: Log, No. 7 (Winter/Spring 2006), p. 21-32. New York: Anyone Corporation.

ARANTES, Otília Beatriz Fiori. Entrevista com Otília Beatriz Fiori Arantes. Rapsódia: Almanaque de Filosofia e Arte[S.I: s.n.], 2002, p. 221-264.

BALLARD, J. G. Milagres da vida. De Shanghai a Shepperton. Uma autobiografia. São Paulo: Companhia das Letras, 2009.

BANHAM, Reyner. Teoria e projeto na primeira era da máquina. São Paulo: Ed. Perspectiva, 2013.

BARDI, Lina Bo. “Uma aula de arquitetura”, in: Silvana Rubino e Marina Grinover (org.), Lina por escrito: textos escolhidos de Lina Bo Bardi 1943-1991. São Paulo: Cosac Naify, 2009, p. 166-176.

BARDI, Lina Bo. O Museu de Arte de São Paulo - Função Social dos Museus. In: Habitat, no. 1, out/dez-1950, p.17. p. $20-23$.

BARDI, Lina Bo. O Novo Trianon 1957 - 67. Mirante das Artes n.5. São Paulo, 1967.

BARDI, Pietro. O programa do MASP. Mirante das Artes n.7. São Paulo, jan./fev. 1967.

BENJAMIN, Walter. Obras escolhidas II. São Paulo: Editora Brasiliense, $20095^{\circ}$ edição, $4^{\circ}$ reimpressão. 2018.

A obra de arte na era de sua reprodutibilidade técnica. Porto Alegre: L\&PM Pocket,

BISHOP, Claire. Artificial Hells. London: Verso, 2012.

Antagonism and Relational Aesthetics. October, vol. 110, 2004, pp. 51-79

BISHOP, Claire (ed.). Documents of Contemporary Art: Participation. London: Whitechapel/ Cambrigde: MIT Press, 2006.

BORASI, Giovanna. Another Way of Building Architecture. (2015). In: https://www.cca.qc.ca/ en/issues/20/the-other-architect/50960/another-way-of-building-architecture (Acesso em 5 nov. 2019).

BORASI; ZARDINI. Actions: What you can do with the City. Quebec: Montreal: Canadian Centre for Architecture, 2008-2009.

BOURRIAUD, Nicolas. Estética Relacional. São Paulo: Martins, 2009.

Formas de vida. A arte moderna e a invenção de si. São Paulo: Martins, 2011.

BRUAND, Yves. Arquitetura contemporânea no Brasil. São Paulo: Editora Perspectiva, 1991 ( $2^{\circ}$ edição).

BUCHLOH, Benjamin. Conceptual Art 1962-1969: From the Aesthetic of Administration to 
the Critique of Institutions. Cambridge: The MIT Press, October, Vol. 55 (Winter, 1990), pp. 105-143.

BUTLER, Cornelia. A Lurid Presence: Smithson's Legacy and Post-Studio Art. In: TSAl; BUTLER (org.). Robert Smithson. Los Angeles: University of California Press, 2004, p.225243

CARMONA-RIBEIRO; OLIVEIRA. Waldemar Cordeiro e o playground do Clube Esperia (2018). Paisagem E Ambiente $n^{\circ} 42$, p. 37-52. In: https://doi.org/10.11606/issn.2359-5361. v0i42p37-52 (Acesso em 18-12-2019).

CONDORELLI, Celine. Support Structures. Berlim: Sternberg Press, 2014.

Life Always Escapes. Nova lorque: E-flux Journal \#10 - Novembro 2009. In: https:// WWW.e-flux.com/journal/10/61357/life-always-escapes/ (Acesso em 2 jan. 2020)

CONDORELLI; GRAZTA. For all ages. The carousels of Céline Condorelli. (2016) In: Utrecht, Metropolis Magazine, $\mathrm{n}^{\circ} 4$ - 2016, Degrowth: https://www.metropolism.com/nl/ features/33598_c_line_condorelli (Acesso em 3 jan. 2020)

CONDORELLI; SEGADE. Conversation Piece. In: GUIDI; SANDOVAL (Ed.). On Curating, issue 36, Spaces of Anticipation, April 2018, p.28-33.

D'AMBROSIO; GRUPO CONTRAFILÉ. A cidade como arte-fato | Contrafilé (2017). In:https:// www.itaucultural.org.br/a-cidade-como-arte-fato-contrafile (Acesso em7 jan. 2020)

DEAMER, Peggy. Practicing Practice (2011). Perspecta, 44, 2011, p.160-203.

DEBORD, Guy-Ernest. Relatório sobre a construção de situações e sobre as condições de organização e de ação da tendência situacionista (1957). In: JAQUES, (org.). Apologia da Deriva. Escritos Situacionistas sobre a cidade. Rio de Janeiro: Casa da Palavra, 2003, p.43-59.

DODD, Mel. Quem faz o Projeto (2017). In: Contracondutas ação político-pedagógica. TONETTI, NOBRE, MARIOTTI, BAROSSI. (ed.). São Paulo: Editora da Cidade, 2017, p. 253258.

DOHERTY, Claire. Situation. Documents of Contemporary Art. London: White Chapel Gallery. Cambridge: MIT Press, 2009.

DRUOT; LACATON; VASSAL. Plus. La vivienda colectiva. Territorio de excepción. Barcelona: Editorial Gustavo Gili, 2007.

EISENMAN, Peter. Supercrítico: Peter Eisenman, Rem Koolhaas. São Paulo: Cosac Naify, 2013,

ELDEN, Stuart. Interview with Lukasz Stanek about Henri Lefebvre, “Toward an Architecture of Enjoyment" and the Use Value of Theory. In: http://societyandspace.org/2014/05/07/on18/ (Acesso em 9/12/2017).

FARIAS, Agnaldo. Por que museus? Catálogo - Agnaldo Farias (curadoria e texto). Museu de Contemporânea de Niteroi. Niteroi, 2006, p. 7-55.

O fim da arte segundo Nelson Leirner. Catálogo - São Paulo: Secretaria do Estado de Cultura, 1995.

Uma volta ao mundo de Nelson Leirner. In: NelsonLeirner 2011-1961 = 50 anos. São Paulo: SESI-SP editor, 2011, p.11-30.

FLAM, Jack. Robert Smithson: The Collected Writings. Los Angeles: University of California Press, 1996.

FERRAZ, Marcelo Carvalho(org.). Lina Bo Bard. Museu de arte de São Paulo.São Paulo: Edições Sesc São Paulo, IPHAN, 2015.

Numa velha fábrica de tambores. Sesc Pompeia comemora 25 anos. Minha Cidade, São Paulo, ano 08, n. 093.01, Vitruvius, abr. 2008. In: https://www.vitruvius.com.br/revistas/ 
read/minhacidade/08.093/1897 (Acesso em 01/02/2020).

FIOR; HEILMEYER. Interview: MUF, art/architecture (2010). In: https://www.baunetz.de/ talk/crystal/index.php?lang=en\&nr=27\&cat=Interview (Acesso em 5 set. 2017)

FISCHLI; KOOLHAAS; OBRIST. Flâneurs in Automobiles: A Conversation between Peter Fischli, Rem Koolhaas, and Hans Ulrich Obrist (2008). In: STADLER, STIERLI (org.). Las Vegas Studio: Images from the Archive of Robert Venturi and Denise Scott Brown. Ed. Hilar Stadler and Martino Stierli in collaboration with Peter Fischli. Zurich: Verlag Scheidegger \& Spiess Ag., 2008, p. 161-170.

FORENSIC ARCHITECTURE (ED.) Forensis. The Architecture of Public Truth. Berlin: Sternberg Press, 2014.

FOSTER, Hall. The Art-Architecture Complex. London: Verso, 2011.

FRIEDMAN, Yona. Architecture without Building. Paris: Édition Cneai, 2012.

Revolt of the Young (2008). In: Log, No. 13/14, Aftershocks: Generation(s) since 1968 (Fall 2008), pp. 33-35. New York: Anyone Corporation.

FRIEDMAN, ORASI - A Conversation With Yona Friedman (2005). In: Log, No. 26 (Fall 2012), pp. 60-75. New York: Anyone Corporation.

GREEN, Alison. "Citizen Artists: Group Material." Afterall: A Journal of Art, Context and Enquiry, no. 26 (2011): 17-25

GREENE, David. Atelier Bow-wow (2008). In: Psicho Buildings. Artists Take on Architecture. London: Hayward Publishing, 2008, p.59-61.

GURIAN, Eduardo Pereira. Marquise do Ibirapuera: suporte ao uso indeterminado. 2014. Dissertação (Mestrado em Projeto de Arquitetura) - Faculdade de Arquitetura e Urbanismo, Universidade de São Paulo, São Paulo, 2014.

HEIZER, OPPENHEIM, SMITHSON. Discussões com Heizer, Oppenheim, Smithson. In: Org. Cecília Ferreira e Cecília Cotrim - Escritos de Artistas Anos 60/70. RJ: Jorge Zahar, 2006, pp. 429/451

JAMESON, Fredric. Pós-modernismo: a lógica cultural do capitalismo tardio, São Paulo, Ática, 1996.

JAQUES, Paola Berenstein (org.). Apologia da Deriva. Escritos Situacionistas sobre a cidade. Rio de Janeiro: Casa da Palavra, 2003.

JENCKS, Charles. Postmodern and Late Modern: The Essential Definitions. Chicago Review, vol. 35, no. 4, 1987, pp. 31-58. JSTOR, www.jstor.org/stable/25305377. (Accessem em 23 Jan. 2020).

LACATON, Anne. We don't much believe in form. Entrevista concedida à Ante Nikša Bilić, Saša Bradić e Vera Grimmer. Croatia: Oris n²4, 2003, p. 108-131.

LEE, Pamela M. Object to be destroyed. The work of Gordon Matta-Clark. Cambridge: MIT Press, 2001.

LEFEBVRE, Henri. O Direito à Cidade. São Paulo: Centauro, 5º edição, 1991.

The production of Space. Oxford: Blackwell Publishers Ltd, 1991.

Toward an Architecture of Enjoyment. Mineapolis: Minnesota Press, 2014.

La presencia e la ausencia. Contribucion a la teoria de las representaciones. Cidade do México: Fondo de Cultura Eonómica, 1983.

GORELIK, Adriàn. Políticas de la representación urbana: el momento situacionista. In: Punto deVista n 86, Buenos Aires, 2006, p. 23-30.

GRASSKAMP, Walter. From Art and the City. (1997) In: Modern Sculpture Reader. Leeds: 
Henry Moore Institute, 2007, pp. 477-484.

GRINOVER; RUBINO (Org.). Lina por escrito. São Paulo: Cosac e Naify, 2009.

GURIAN, Eduardo. Marquise do Ibirapuera. Suporte ao uso indeterminado. Dissertação de mestrado apresentada à Faculdade de Arquitetura e Urbanismo da Universidade de São Paulo, 2014.

HAYS, Michael. Architecture Theory Since 1968. Cambridge: MIT Press, 1998.

HARVEY, David. A Produção Capitalista do Espaço. Trad. Carlos Szlak. São Paulo, Annablume, 2006.

Afterword (1992). In: LEFEBVRE, Henri. The Production of Space. Oxford: Blackwell Publishers Ltd, 1991, p.424-434.

HEILMEYER, Florian. Interview 27 MUF Art and Architecture, 2010. In: http://www.baunetz. de/talk/crystal/index.php?lang=en\&cat=Profil\&nr=27 (consultado em 9/12/2017).

HEJDUK, John. Victims. London: Architecture Association, 1986.

HUBER, Beyond Belief: The Architecture of Lacaton \& Vassal. Nova lorque: Artforum, Vol. 53, n9, maio 2015, p.342-347.

Lacton \& Vassal (2016). In: http://davidhuber.info/lacaton-vassal-housing/ (Acesso em 20 ago. 2019).

JAMESON, Fredric. Pós-modernismo: a lógica cultural do capitalismo tardio, São Paulo, Ática, 1996.

KAIJIMA, Momoyo. Learning from Architectural Ethnography (2018). In: Atrium Behaviorology. Hamburgo: Hafen City University, 2018 p. 51-58. In: http://urban-design-reader.de/ pdf?uri=atrium-behaviorology (Acesso em 18 jan. 2020).

KELLEY, Mike. "Repressed Architectural Memory Replaced with Psychic Reality". Nova lorque: ANY No. 15, Return of Repressed Architectural Memory (1996), pp. 36-39.

KUNSCH, Graziela. Projeto Mutirão: um filme não-realizável, uma prática documentária (2016). In: Periódico Permanente, $n^{\circ} 6$, Seção 5, Mediação Documentária. In: http://www. forumpermanente.org/revista/numero-6-1/conteudo/projeto-mutirao (Acesso em 10 out. 2019).

KRAUSS, Rosalind. Sculpture in the expanded Field. In: October, vol. 8, Spring, 1979, p.30-44 Cambridge: MIT Press, 1978, p. 277/290.

The Cultural Logic of the Late Capitalist Museum. In: October Vol. 54, Autumn, 1990.

KWON, Miwon. One Place after Another: Site-Specific Art and Locational Identity. Cambridge, MIT Press, 2002.

Approaching Architecture: The Cases of Richard Serra and Michael Asher. Yale Üniversity Art Gallery Bulletin, 2009, pp. 44-55.

LAGNADO, Lisette. Por uma revisão dos estudos curatoriais (2015) - In: Revista Poiésis n²6, p.81-97.

Desvíos de la deriva: experiencias, travesías, morfologia. In: BERRIOS; LAGNADO. Desvíos de la deriva, experiencias travesías y morfologias. Museo Nacional Centro de Arte Reina Sofia, 2010, p.52-67.

Em conversação com Carolyn Christov-Bakargiev (2010) -In: http://forumpermanente. tangrama.com.br/event_pres/exposicoes/documenta-13/em-conversacao-com-carolynchristov-bakargiev (Acesso em 21 out. 2019).

LINDER, Mark. Nothing Less Than Literal. Architecture after Minimalism. Cambridge: MIT Press, 2004. 
Towards "A New Type of Building": Robert Smithson's Architectural Criticism. In: TSAI; BUTLER (org.). Robert Smithson. Los Angeles: University of California Press, 2004, p. 189-205.

LIPPARD, Lucy. Six Years: The dematerialization of the art object. Los Angeles: University of California Press, 1997.

LEIRNER; MARTÍ. Masp inicia onda de remakes com 'Playgrounds' de Nelson Leirner. Folha de São Paulo: edição de 17 mar. 2016. Disponível online: https://www1.folha.uol.com.br/ ilustrada/2016/03/1750659-masp-inicia-onda-de-remakes-com-playgrounds-de-nelsonleirner.shtml?origin=folha (Acesso em em 8 dez. 2019).

LOPES, Almerinda da Silva. Apropriação e ironia na instalação ‘Vestidas de branco’ de Nelson Leirner(2016). Revista Estúdio, Artistas sobre outras Obras (14), p. 36-43.

MAIA, Ana Maria. Museu de Cera, Pavilhão da Marquise, Pavilhão Bahia, Museu de Arte Moderna de São Paulo. In: $33^{\circ}$ Panorama da Arte Brasileira. P33. Formas únicas da continuidade no espaço. Catálogo, Museu de Arte Moderna de São Paulo - São Paulo, 2013, p. 29-37.

MAIA, Carmen. Cildo Meireles. Rio de Janeiro: Funarte, 2009.

MARQUES; LELO. Aspectos poéticos-comunicacionais da filosofia política de Rancière a partir dos conceitos de dano, dissenso e desidentificação. Porto Alegre: Intexto, PUFRGS, n. 31, p. 52-67, dez. 2014.

MARTIN, Reinhold. “Utopia's Ghost. Architecture and Postmodernism, Again”. Mineapolis: Minnesota Press, 2010.

Conjuring Utopia's Ghost. Reinhold Martin interviewed by Jonathan Crisman. Cambridge: SA+P Press, Tresholds 40 - Socio, 2012, p. 11-20.

MARTINS, Patrícia. Changing Practices. Um relato sobre o RIBA Research Symposium 2009. Drops, São Paulo, ano 10, n. 031.09, Vitruvius, maio 2010 https://www.vitruvius.com.br/ revistas/read/drops/10.031/3423 (Acesso em 2 out. 2019).

MATTOS; WISNIK (org.) Cildo. Estudos, espaço, tempo. São Paulo: Ubu, 2017.

MUSSI, Joana Zatz. Arte em fuga. 2017. Tese (Doutorado em Projeto, Espaço e Cultura) Faculdade de Arquitetura e Urbanismo, Universidade de São Paulo, São Paulo, 2017

MIESSEN, Markus. Crossbenching. Toward Participation as a Critical Spacial Practice. Berlin/New York: Sternberg Press, 2016.

Crossbenching.Towards a proactive mode of participation as a Critical Spatial Practice. Tese de doutorado sob orientação do prof. Dr. Eyal Weizman: Centre for Research Architecture da Goldsmiths College / University of London, 2017.

MIYADA, Paulo. Projeto e indeterminação. A obra de Carlos Teixeira. Resenhas Online, São Paulo, ano 10, n. 119.02, Vitruvius, nov. 2011 <https://www.vitruvius.com.br/revistas/read/ resenhasonline/10.119/4102>. (Acesso em 8 nov. 2019).

MONEO, Rafael. Inquietação teórica e estratégia projetual na obra de oito arquitetos contemporâneos. São Paulo: Cosac Naify, 2008.

MORRIS, Robert. O tempo presente no espaço (1978). In: FERREIRA;COTRIM (orgs.) Escritos de artistas. Anos 60/70. Rio de Janeiro:Jorge Zahar Editor, p. 401-420.

MUNTADAS, Antoni. Riflessioni per una metodologia del progetto. For A Project Methodology. Mono Editions, 2013: http://intheexpandedfield.com/img/full/muntadas.pdf (Acesso em 25 jul. 2019).

NESBITT, Kate (org.), Uma nova agenda teórica para a arquitetura. São Paulo: Cosac Naify, $2^{\circ}$ ed., 2008. 
NIELSEN, Palle. A model for a qualitative society (1968). In: https://www.macba.cat/PDFs/ palle_nielsen_eng.pdf (Acesso em 6 dez. 2019).

OBRIST (org.) - Yona Friedman (1998-2002) - In: Hans Ulrich Obrist Interviews, Vol. 1 (2013). Firenze: Charta/Fondazione Pitti - p. 233-242.

The Conversation Series n²1.Cedric Price. Colonia: Verlag der Buchhandlung, 2009.

O'DOHERTY, Brian. No interior do cubo branco: a ideologia do espaço da arte. São Paulo: Martins Fontes, 2002.

OITICIA, Helio. Aspiro ao grande labirinto. Rio de Janeiro: Rocco, 1986.

OLIVEIRA, Olívia. Os antimuseus e antiescolas de Lina Bo Bardi e Paulo Freire. In: Concreto e Cristal: O Acervo do MASP nos Cavaletes de Lina Bo Bardi Bardi PEDROSA; PROENÇA (ed.). Rio de Janeiro: Cobogó, 2015, p. 84-91.

OTA, Kayoko. The Posturban Phenomenon (2018). In: https://www.cca.qc.ca/en/articles/ issues/26/what-about-the-provinces/56442/the-posturban-phenomenon (Acesso em 6 jan. 2020).

OUDENAMPSEN, Merijn. A cidade como playground. PISEAGRAMA, Belo Horizonte, número 03, 2011, p. 52 - 55.

PASSARO, Lais Bronstein. Arquitetura e solidão: John Hejduk em Berlim (2003). Risco Revista De Pesquisa Em Arquitetura E Urbanismo (Online), (1), 44-58. Acesso em 12 set. 2018.

PEDROSA, Mario. Arte ambiental, arte pós-moderna, Hélio Oiticica (1965). In: Aspiro ao grande labirinto. Rio de Janeiro: Rocco, 1986, p. 9-13.

Do porco empalhado ou os critérios da crítica (1968) In: Gloria Ferreira (org.) - Crítica de Ârte no Brasil: temáticas contemporâneas. Rio de Janeiro: Funarte, 2006, p. 207-210.

PEIRANO, Mariza. Etnografia não é método (2014). In: Horizontes Antropológicos, Porto Alegre, ano 20, n. 42, jul./dez. 2014, p. 377-391.

PERROTTA-BOSCH, Francesco. A arquitetura dos intervalos (2013). In: https://www. revistaserrote.com.br/2013/12/a-arquitetura-dos-intervalos-por-francesco-perrotta-bosch/ (Acesso em 21 ago. 2019).

PETRESCU; TROGAL (ed.). The Social (Re)Production of Architecture. New York: Routledge,2017.

PISANI, Danieli. O Trianon do MAM ao MASP. Arquitetura e política em São Paulo (19461968). São Paulo: Editora 34, 2019.

MASP breve história deum mito. In: Revista PROJETOdesign, ed. set/out 2017, p. 2-9.

RANCIĖRE, Jacques. A partilha do sensivel. Estética e política. São Paulo: EXO experimental; Editora 34, 2009 ( $2^{\circ}$ edição).

O espectador emancipado. São Paulo: Editora WMF Martins Fontes, 2012.

RENDELL, Jane. Art and Architecture: A Place Between. London: IB Tauris, 2006.

Site-Writing: The Architecture of Art Criticism. London: IB Tauris, 2011.

ROSLER, Martha. “Travel Stories". Cambridge: The MIT Press, Grey Room, No. 8 (Summer, 2002), pp. 108-137.

RUGAARD, Dorothy Juul. The Model 2014 - A Model for Qualitative Participation (2015). In: The Model. Palle Nilsen. Estocolmo: ARKEN Museum of Modern Art, p.12-23.

SÁNCHEZ LLORENS, Mara. La Gran Vaca Mecánica. Arquitextos, São Paulo, ano 11, n. 124.05, Vitruvius, sep. 2010. In: https://www.vitruvius.com.br/revistas/read/arquitextos/11.124/3510 (Acesso em 30 dez. 2019) 
SANROMÁN, KANTOR (ed.). Tania Bruguera. Talking to Power/Hablando al Poder. San Francisco: Yerba Buena Centre for the Arts, 2018.

SCOTT, Felicity D. Architecture or Techno-utopia, Politics after Modernism. Cambridge, MIT Press, 2007.

Outlaw Territories. Environments of Insecurity / Architectures of Couterinsurgency. Nova lorque: Zone Books, 2016. p.65-69.

Operating Platforms. In: LOG n²0 - Fall 2010 -Nova lorque: Anyone Corporation.

Arquitetura como uma tecnologia política (2017) In: Contracondutas. Ação políticopedagógica. TONETTI, NOBRE, MARIOTTI, BAROSSI (Ed.). São Paulo: Editora da Cidade. p. 47-67, 2017.

SINGERMAN, Howard. The Educational Complex. Mike Kelley's Cultural Studies. Cambridge: MIT Press, October, Vol. 126 (Fall, 2008), pp. 44-68.

SCHOLLETE, Gregory. Snip, Snip...Bang, Bang: Political Art, Reloaded (2008). http://www. gregorysholette.com/wp-content/uploads/2011/04/SnipSnipBangBang.1.pdf (Acesso em 15 out. 2019) pp. $98-101$.

A User Is Haunting the Art World (2015). In: Art Journal, Vol. 74, No. 1 (Spring 2015),

SCHARTZ, Alexandra (org.). Ed Ruscha. Leave any Information at the Signal. Writings, Interviews, Bits, Pages. Cambridge: MIT Press, 2004.

STANEK, Lucasz. Henri Lefebvre on Space. Architecture, Urban Reseach, and the Production of Theory. Mineapolis: Minnesota Press, 2012.

p. 48-53.

Architecture as Space, Again? Notes on the 'Spatial Turn'. In: SpecialeZ, Vol. 4, 2012,

STADLER; STIERLI (Ed.). Las Vegas Studio: Images from the Archive of Robert Venturi and Denise Scott Brown. Zürich: Scheidegger and Spiess, 2009.

STOTT, Tim. Lessons in Playing: A Current Work of Art as a Biopolitical Milieu. Philosophy at Play conference, University of Gloucestershire, 9th to 10th April 2013. In: https://arrow. tudublin.ie/aaschadpcon/9/ (Acesso em 1 dez. 2019).

TEIXEIRA, Carlos Moreira. Entre. Belo Horizonte: Instituto Cidades Criativas, 2010.

TILL; SCHNEIDER; AWAN. Spatial Agency: Other Ways of Doing Architecture. Londres: Routledge, 2011.

TSCHUMI, Bernard. Architecture and disjunction. Cambridge: MIT Press, 1996.

Introdução: notas para uma teoria da disjunção arquitetônica (1988). In: NESBITT(org.), Uma nova agenda teórica para a arquitetura. São Paulo: Cosac Naify, $2^{\circ}$ ed., 2008, p.188-191.

VAN EYCK, Aldo. Sobre el diseño del equipamento lúdico y la disposición selos espacios de juego (1962). In: Playgrounds. Reinventar la plaza. BORJA-VILLEL; VELAZQUZ; BRINGAS (ORG.) 2014, p.120-135.

Um dom superlativo. In: Lina Bo Bardi. Museu de arte de São Paulo. FERRAZ (org.), Edições Sesc São Paulo, IPHAN, 2015, p.48-58.

VASSAL, Jean Philippe Vassal. Entrevista concedida à Felipe De Ferrari M. and Kim Courréges. (2009). In: www.onarchitecture.com (Acesso em 11 abr. 2019).

VAN GERREWEY, Christophe. Goodbye Paper (2017). AA Files, no. 74, 2017, pp. 98-111.

VENTURI, Robert. Complexidade e contradição em arquitetura. São Paulo: Martins Fontes, $2^{\circ}$ edição, 2004. 
VIDLER, Anthony. Technologies of Space/Spaces of Technology. In: Journal of the Society of Architectural Historians, Vol. 58, No. 3, Architectural History 1999/2000. University of California Press: 1999, pp. 482-486.

The Building in Pain: The Body and Architecture in Post-Modern Culture. Londres: Architectural Association School of Architecture, AA Files, No. 19 (Spring 1990), pp. 3-10.

Diagrams of Diagrams: Architectural Abstraction and Moderns Representation. In: Representations $n^{\circ}$ 72, Fall 2000, University of California Press, p.1-18. Press, 2001.

Warped Spaces. Architecture and Anxiety in Modern Culture. Cambridge: The MIT

Toward a Theory of the Architectural Program. In: October, n 106, Fall 2003, p.5974. Cambridge, MIT Press.

O Campo Ampliado da Arquitetura (2005). In: SYKES, Krista A. (org.). O campo ampliado da arquitetura. Antologia teórica (1993-2009). São Paulo: Cosac Naify, 2013, p. 242251.

VILA-MATAS, Enrique. Não há lugar para lógica em Kassel. São Paulo: Cosac \& Naify, 2015.

VENTURI, Robert. Complexidade e contradição em arquitetura. São Paulo: Martins Fontes, $2004,2^{\circ}$ edição.

VENTURI; SCOTT-BROWN; IZENOUR. Aprendendo com Las Vegas. São Paulo: Cosac e Naify, 2003.

VILAÇA; CONSTANTE (org.); AYERBE (ed.). Usina: entre o projeto e o canteiro. São Paulo: Edições Aurora, 2015.

WALKER, Enrique. The ordinary: Recordings. Nova lorque: Columbia Books on Architecture and the City, 2018.

WISNIK, Guilherme. Dentro do nevoeiro: diálogos cruzados entre arte e arquitetura contemporânea. São Paulo: Faculdade de Arquitetura e Urbanismo, Universidade de São Paulo, 2012. Tese de Doutorado em História e Fundamentos da Arquitetura e do Urbanismo.

WRIGHT, Stephen. Para um léxico dos usos. São Paulo: Edições Aurora, 2016.

ZAERA-POLO, Alejandro. Cheapness: No Frills and Bare Life (2010). In: Log, No. 18 (Winter 2010), pp. 15-27. New York: Anyone Corporation.

ZANATTA, Cláudia Vicari. Coletivo Contrafilé: arte participativa, educação e política como ação. In: Centro de Investigação e Estudos em Belas-Artes (CIEBA), Faculdade de BelasArtes, Universidade de Lisboa. Artes em construção: o IX Congresso Criadores Sobre Outras Obras -2018, p. 265-274.

\section{Catálogos}

A Marquise, o MAM e nós no meio. Ana Maria Maia (curadoria e textos) São Paulo: Museu de Arte Moderna de São Paulo, 2018.

Catálogo da $29^{\circ}$ Bienal de São Paulo: Há sempre um copo de mar para um homem navegar/ curadores Agnaldo Farias, Moacir dos Anjos. São Paulo: Fundação Bienal de São Paulo, 2010.

P33: Formas únicas da continuidade no espaço. Panorama da Arte Brasileira 2013.Lisette Lagnado (curadora); Ana Maria Maia (curadora-adjunta). São Paulo: Museu de Arte Moderna de São Paulo, 2013.

Playgrounds 2016. Adriano Pedrosa; Julieta Gonzales; Luiza Proença (curadoria e textos). São Paulo: MASP, 2016. 


\section{Filmes}

Hacer Mucho con Poco. Direção: Katerina Kliwadenko e Mario Novas. Argumento:

Al Borde e Kliwadenko Novas. Ecuador e Espanha: 2017, 86 min.

Iconoclássicos - Nelson Leirner: Assim é, se the parece. Direção:

Carla Gallo. São Paulo: Itaú Cultural, 2011, 75min.

Islands and Villages. Atelier Bow-Wow in Momonoura. Toronto: CCA, 2018, 14min 11". In:

https://www.cca.qc.ca/en/articles/issues/26/what-about-

the-provinces/56455/islands-and-villages

\section{Conferências}

Jacques Rancière: How does Architecture Distribute de Sensible? Peggy Deamer, Anthony Vidler, Michael Young, Joan Ockman e Jacques Rancière (16 nov. 2019) - In: https:// architecture.exchange/exchange/ranciere/

Temple Talks with Céline Condorelli (29 set. 2016) - In: https://www.la-loge.be/event/ temple-talks-1

O Museu do Agora: Arte Contemporânea, Historias de Curadoria, Modelos Alternativos. Seção: Revisitando o Museu do Capitalismo Tardio - Beatriz Colomina (Mar. 11, 2011). In: http://www.forumpermanente.org/event_pres/simp_sem/conferencia-internacional-thenow-museum/videos/o-museu-do-agora-beatriz colomina

\section{Sites}

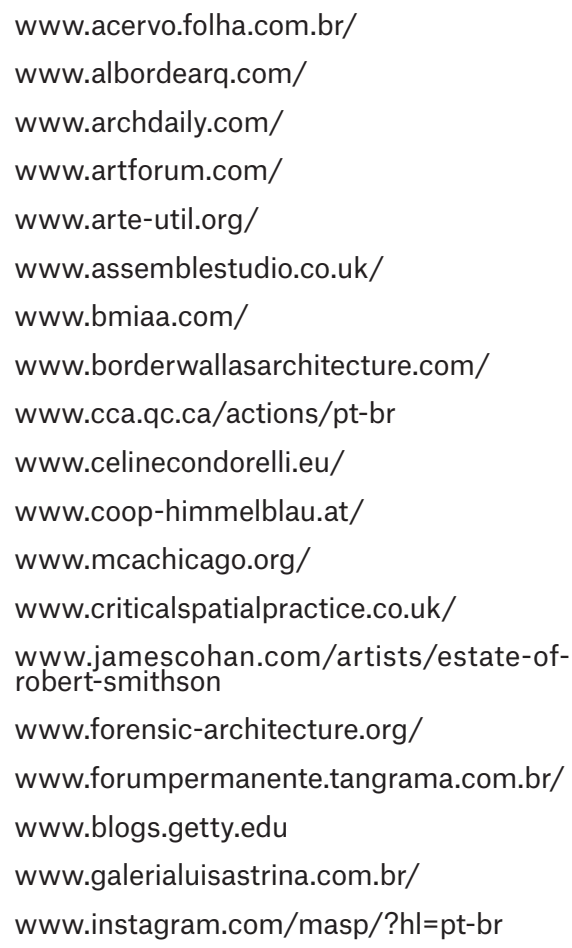

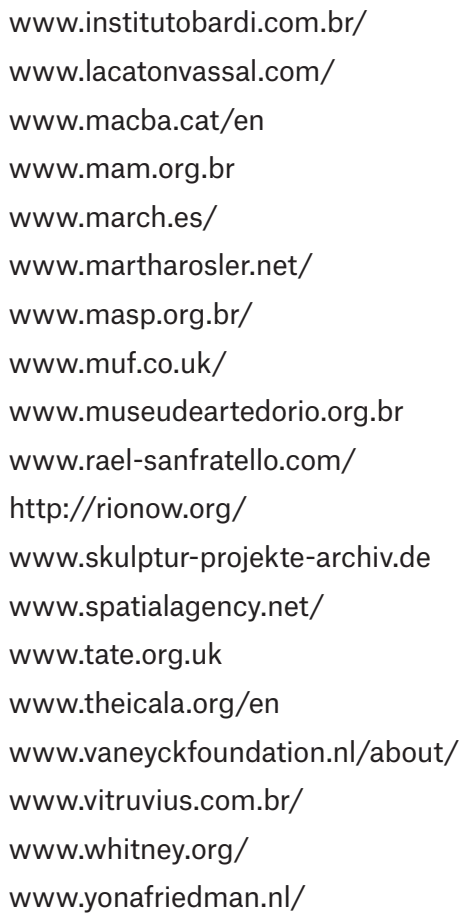




\section{Índice de imagens}

\section{Introdução}

1a e 1b p. 20 - Rael SanFratello

2a e 2b p. 21 - Zander Olsen / Assemble

\section{Caderno de Imagens 1}

\begin{tabular}{|c|c|c|}
\hline \multirow[t]{2}{*}{ C1.1 } & p.70 & Denise Scott Brown \\
\hline & & $\begin{array}{l}\text { Fisionomia de um letreiro típico de cassino (VENTURI, SCOTT } \\
\text { BROWN, IZENOUR, 2003, p.93) }\end{array}$ \\
\hline C1.2 & p.71 & Ed Ruscha (Getty Center) \\
\hline C1.3 & p.72 & Martha Rosler \\
\hline C1.4 & p.73 & The Mike Kelley Foundation for the Arts (Witney Museum) \\
\hline C1.5 & p.74 & Gertrud Wolfschwenger, Wien (Coop Himmelb(I)au) \\
\hline C1.6 & p.75 & Grant Mudford (Institute of Contemporary Art, Los Angeles) \\
\hline C1.7 & p.76 & Dickie Landry alterada por Gordon Matta-Clark. \\
\hline \multirow[t]{2}{*}{ C1.8 } & p.77 & Group Material \\
\hline & & Thomas Lawson (Artforum 1981 - Apr.) \\
\hline C1.9 & p.78 & Arte Útil \\
\hline C1.10 & p.79 & Galeria Luisa Strina \\
\hline
\end{tabular}

\section{Caderno de Imagens 2}

\begin{tabular}{|c|c|c|}
\hline C2.1 & p.144 & Lacaton \& Vassal \\
\hline \multirow[t]{2}{*}{$\mathrm{C} 2.2$} & p.145 & ArchiAid Oshika Peninsula Supporting Seminar \\
\hline & & Still do filme: Islands and Villages. (CCA, 2018) \\
\hline $\mathrm{C} 2.3$ & p.146 & muf architecture/art \\
\hline $\mathrm{C} 2.4$ & p.147 & Cedric Price/Joan Littlewood. Fun Palace promotional brochure (CCA) \\
\hline $\mathrm{C} 2.5$ & p.148 & Yona Friedman \\
\hline $\mathrm{C} 2.6$ & p.149 & Yona Friedman \\
\hline $\mathrm{C} 2.7$ & p.150 & Cristobal Palma (ELEMENTAL/ Archdaily) \\
\hline \multirow[t]{2}{*}{$\mathrm{C} 2.8$} & p.151 & Carlos Cuenca + Raed Gindeya + Al Borde \\
\hline & & Al Borde + Kliwadenko Novas \\
\hline $\mathrm{C} 2.9$ & p.152 & Museu de arte do Rio de Janeiro (MAR) \\
\hline $\mathrm{C} 2.10$ & p.153 & John Hejduk Archive / CCA \\
\hline $\mathrm{C} 2.11$ & p.154 & Robert Smithson (MCA Chicago) \\
\hline $\mathrm{C} 2.12$ & p.155 & Forensic Architecture \\
\hline
\end{tabular}




\section{Caderno de Imagens 3}

\begin{tabular}{|c|c|c|}
\hline C3.1 & p.204 & Eduardo Gurian \\
\hline \multirow[t]{2}{*}{ C3.2 } & p.205 & Marcel Gautherot (Acervo Instituto Moreira Sales/LAGNADO; MAIA, 2013, p. 159) \\
\hline & & $\begin{array}{l}\text { Still do filme Museu de Arte da Pampulha de Yuri Firmeza e Amanda Melo } \\
\text { (LAGNADO; MAIA, 2013, p. 163) }\end{array}$ \\
\hline C3.3 & p.206 & Rômulo Fialdini (LAGNADO; MAIA, 2013, p. 183) \\
\hline \multirow[t]{2}{*}{ C3.4 } & p.207 & Rômulo Fialdini (LAGNADO; MAIA, 2013, p. 52-53) \\
\hline & & Instituto Lina Bo e P. M. Bardi (LAGNADO; MAIA, 2013, p. 73) \\
\hline \multirow[t]{2}{*}{ C3.5 } & p.208 & Karina Bacci ((MAIA, 2019 p. 182-183) \\
\hline & & Karina Bacci (MAIA, 2019, p. 76-77) \\
\hline \multirow[t]{3}{*}{ C3.6 } & p.209 & Karina Bacci (MAIA, 2019, p. 94-95) \\
\hline & & Karina Bacci (MAIA, 2019,, p. 126-127) \\
\hline & & Karina Bacci (MAIA, 2019, p. 108-109) \\
\hline C3.7 & p.210 & Nelson Kon (Vitruvius) \\
\hline C3.8 & p.211 & Per Hüttner (CONDORELLI, 2014, p120-121). \\
\hline C3.9 & p.212 & Instituto Lina Bo e P. M. Bardi \\
\hline C3.10 & p.213 & Acervo Folha de São Paulo. \\
\hline C3.11 & p.214 & Centro de Pesquisa MASP \\
\hline C3.12 & p.215 & Palle Nielsen (MACBA) \\
\hline C3.13 & p.216 & Performance at Tate: Into the Space of Art, Tate Research Publication, 2016. \\
\hline C3.14 & p.217 & Aldo Van Eyck Archive \\
\hline C3.15 & p.218 & Pierre Yves Refalo (Fundación Juan March) \\
\hline C3.16 & p.219 & MASP (Instagram) \\
\hline C3.17 & p.220 & Eduardo Ortega (Celine Condoreli) \\
\hline
\end{tabular}

